\title{
Voyages as Exercises of the Gaze
}

\author{
Sylvia Caiuby Novaes \\ Universidade de São Paulo
}

\begin{abstract}
This article focuses the relationship between journeys and photographs especially among anthropologists who travel. Having travelled to the Upper Negro River as an advisor of a PhD student, I discuss what digital photographs may mean in a context where verbal communication is impossible. Real or imaginary journeys are a source of images, reports, or travel logs in which it is difficult to discern what is real and what is fiction. After discussing a few famous scientific and literary journeys, the article focuses on some anthropological journeys and concludes that images produced by anthropologists are a result of trained intuition, a sensitive gaze, and memories of former travels. The article includes photographic essays that incorporate pictures I took in February 2012 among the Hupd'äh, in the Upper Negro River region.
\end{abstract}

Keywords: Real and imaginary journeys; images; photography; memory; imaginary.

\section{Resumo}

$\mathrm{O}$ artigo tem como foco as relações entre viagens e fotografia, com especial atenção aos antropólogos que viajam. Viajei para o Alto Rio Negro como orientadora de uma doutorando e discuto o significado de fotos digitais num contexto em que a comunicação verbal não é possível. Viagens reais ou imaginárias são fontes de relatos, de diários e de imagens, onde é difícil distinguir o que é real do que não é. Após refletir sobre algumas viagens científicas e literárias famosas, o artigo retoma algumas viagens antropológicas e conclui que as imagens produzidas por antropólogos são o resultado de uma intuição treinada, de uma observação sensível e de memórias de viagens anteriores. $\mathrm{O}$ artigo inclui ensaios fotográficos com imagens por mim captadas em Fevereiro de 2012, na viagem que fiz com Danilo Paiva Ramos, na época meu 
orientando no doutorado, aos Hup'däh em fevereiro de 2012.

Palavras-chave: Viagens reais e imaginárias; imagens; fotografia; memória; imaginário. 


\title{
Voyages as Exercises of the Gaze
}

\author{
Sylvia Caiuby Novaes \\ Universidade de São Paulo
}

\begin{abstract}
"Reality is one frame; fiction, another. Dream, fantasy, madness, passion [...] are so many other framings through which we discern and organize what is going on around us, which may or may not be real. “
\end{abstract}

Roberto da Matta

My purpose here is to reflect, from the anthropological perspective, on some associations between voyage and images. While overviewing real and imagined voyages, my ultimate aim is to look at how anthropologists use photographs when doing field research. Finally, I shall make some points on the significant use of images in anthropology. ${ }^{1}$

To begin my reflection along what is maybe a sinuous path, I wish to revisit certain issues related to anthropological practice that were raised some time ago by authors such as Clifford and Marcus (1986), and Geertz (2002). Whereas Edward Sapir and Ruth Benedict once had to hide their poems from Franz Boas, today we are seeking to usher new language resources in the study of anthropology. In his introduction to their mid-1980s book that set a milestone for the discipline (Clifford and Marcus, 1986:4), Clifford wrote “... the notion that literary procedures pervade any work of cultural representation is a recent idea in the discipline". Since then, many anthropologists have insisted that rhetoric, fiction and subjectivity are part of the discipline of anthropology, rather than exclusive elements of literature. While ethnographic writing is not fictional in the sense of fabrication, it is necessarily partial and incomplete; in particular, it evinces a researcher's engagement with the

\footnotetext{
1 I wish to thank Francirosy Ferreira for her instigative reading. Also I could not fail to thank Vibrant's reviewer, whose comments encouraged me to reformulate this article. I also want to thank PPGAS-USP for making this translation possible and Elizabeth Ewart for the revision of the English subtitles in the PowerPoint. This article has been made possible by research conducted with FAPESP funding.
} 
group studied, and the relationships he/she was able to establish with people he/she met and lived with while researching.

There is another issue that interests me on this winding path of looking at possible associations between voyages and images, or between anthropologists who travel and photograph, namely "the obsession with truth" pertaining in discussions on photography ever since the camera was invented in the mid-19th century. ${ }^{2}$ The same discussion is there between the lines, in a certain sense, when the subject of ethnographic writing is raised, as noted above. The question of the true or false nature of a photographic image, of spontaneity as opposed to posed shots, or taking a snapshot as opposed to setting a scene, is a constant issue in the discussion of numerous photographs, the best known being the war photographs that became iconic, such as Rosenthal's 1945 shot of soldiers raising the flag on Iwo Jima in World War II, or Robert Capa's 1936 photo of a soldier fallen during the Spanish Civil War, or to mention a controversy over older photos, Alexander Gardner's 1863 scene of Gettysburg during the American Civil War. Precisely these images were revisited in an interview with the photographer and filmmaker Errol Morris (2012), in which he refers to the photographic image as something that is physically connected to the world, and in this sense its analysis is something that attempts to reestablish or retrieve this physical link with the world in which they were taken. An aspect that makes analysis difficult, according to Morris, is that "photographs do something tricky. They decontextualize things. They rip images out of the world and as a result we are free to think whatever we want about them." (Morris, 2012:127). This "complication" noted by Morris may be useful for an analysis of the topic I have proposed.

Before introducing more bends on this winding road, I shall put forward my argument: in the case of anthropologists too, images from field trips may be an important means of organizing their gaze and their own travel experience. Voyages are displacements in space that offer opportunities of immersion in new landscapes. Starting out from familiar and well-known space, voyagers head for the unknown. Everything changes: landscape, references, people, and ways of communicating. Voyages always involve defamiliarization, an attitude highly appreciated in scientific practice. But they also

2 For an important reference on the question of the relationship between true and false in photography, see Rouillé 2009 . 
involve much imagination and re-elaboration of what was known. ${ }^{3}$ Images are conducive to the act of imagining and here we have an initial association between journeys and photography.

In this sense, through his photographs a traveler-anthropologist is able to express his experience in a way that is not always possible in writing. By recording views selected by the gaze, photographs also organize the observer's visual experience. Would not this be, perhaps, the most obvious relationship between taking a voyage and taking photographs? Traveling and photographing yield a relationship with the world. Like a travelogue, a photograph is a visual record of something we wish to learn, although not necessarily involving scientific knowledge subject to the methodological rigor of a discipline. But, as Sontag points out, photographs provide a new visual code: "They are a grammar and, even more importantly, an ethics of seeing" (Sontag 1986:13). Photos taken by an anthropologist in the field may also interfere with what he already knows from other contexts. "[Photographs] are clouds of fantasy and pellets of information," she adds (Sontag 1986:69).

Voyages are charged not only with defamiliarization, but also with retrieved memories. At each new journey, memories from other visits are revisited. Our travel accounts or images are always imbued with memories, because every visit retrieves images from a previous visit, like a palimpsest. A journey brings up the awareness of similarities and differences between what the voyager knew from previous travels and the new landscapes unfolding before his eyes. Photographs comprise this new experience that is somehow guided by previous ones. ${ }^{4}$

In February 2012, Danilo Paiva Ramos and I travelled to the Upper Negro River basin to visit a village of the Hupd'äh, an indigenous people of the Maku language group. Our objective was to continue the research work I have been conducting as part of a FAPESP funded project on the specificities of photographic language and the potential of using photographs to

3 Perhaps this is why the history of anthropology began with absolutely strange and distant societies, and even today it is research into these societies that marks work on the discipline's major theoretical perspectives.

4 In this respect, the gaze that leads to the production of photographs is like the artist's gaze. “... we shall then conclude that, just like it happens in any given culture, perception as physiological process and the projection of knowledge are closely associated in every act of seeing. As mental operations they are inseparable from all acts of seeing." Severi wrote (2011:13, translated for this article), in revisiting points made by Baxandall. 
compose short essays, from an anthropological perspective. The empirical universe to be tested for these essays comprises the various research projects for which I am advisor.

It is also my objective to share fieldwork with my advisees and learn more about their research themes. The act of photographing during these trips brings me closer to their research realm without overly intervening. ${ }^{5}$ Having spent over 30 years researching the Bororo people of the state of Mato Grosso, these visual ethnographies in such diverse fields of study are a chance to "defocus" my gaze, for they evoke new sensibilities and, eventually, may lead to new reflections based on a broader range of research universes.

Advising students on site while they are doing field work had not been part of my experience, but I now realize that dialogue with a student may take place on another level in this situation. All the more so for the case in question, which was a research project undertaken by Danilo Paiva Ramos in the Upper Negro River basin. Time passes differently in an Indian village. Life is lived at a different pace. If we were in Sao Paulo, I never would get ten full days to act as advisor. On the other hand, taking photographs depends solely on my own initiative, and enables me to communicate with people in a specific way. It poses the possibility of shared anthropology in a rather different sense from that advocated by Jean Rouch. For a short time, we shared the field work, talked about research strategies, and discussed how data may be interpreted. While on the site I could point out certain elements present in the bibliography, or remark on contexts that seem to yield a wealth of content for the topic being researched. Had I not been present, we would hardly have attained the same level of discussion.

Before traveling to the Hupd'äh village, I noticed that Danilo had collected data from the male universe only. The focus of his research is the rounds of ipadu [coca], or Erythroxylum coca, held almost nightly by groups of older men. Their narratives during these sessions refer to their way of life, to the past, their ancestors, and the current status of their people. Danilo hopes "to interpret these narrative events in a broader context involving ritual life, cosmology, representations of contact, social tensions, contradictions and mediations characterizing the manner in which the Hupd'äh experience the

5 It is impossible not to interfere to some extent. I have heard it said that an advisor in the field would be Lacan's Great Other. 
world." (Paiva Ramos, p. 3, FAPESP report). Without a doubt, the ipadu intake is a theme that belongs in the male universe, but even so I was intrigued by the total absence of women and children in my student's data.

In an indigenous village, men and women lead very different everyday lives, often apart, since gender is a more constant marker than in our own society's everyday living. Any anthropologist who has spent a long time researching the same native Indian society will realize the extent to which their own gaze shifts over the years, in their own life cycle. If doing field work means being immersed in a totally different universe, then there is no way researchers could rid themselves of their subjectivity and the way it transforms both itself and the gaze over time. As a woman, a mother and now a grandmother, I was able to establish good rapport with women and children during the time I spent in the village. The Hupd'äh in general do not speak Portuguese, and there were only two men there able to do so to some extent, and even then with plenty of room for misunderstandings. For the first time in my life I was in a context in which I had no linguistic ability to communicate with people verbally.

Unlike many indigenous people I have known, the Hupd'äh love having their photograph taken, so I got numerous requests for photos as mothers posed with their children, girls combed their hair, boys fetched their bows or pets, or threw a spinning top for me to photograph them. I took countless photos of children. In particular, I was delighted by four small children who were home alone all afternoon, while their mother was away working the fields. Those children set up a real "camp" consisting of three homes, sleeping hammocks, an oven with a large pan, tables, and in each home they burned twigs to roast food for real.

On another day, on a five hour trek in the countryside, I was able to go along with one of the women and her daughter to collect cassava and pupunha palm. It was embarrassing having to be helped across streams along trunk bridges, afraid of losing my balance and being unable to carry anything other than the photo equipment. On the other hand, it was delightful to be invited to plant cucura, an Amazonian edible fruit somewhat like jabuticaba. Communication is restricted but possible, even when one side does not understand the semantics of the other's language. New forms of communication and exchange are introduced by digital photography, which allows images to be shown to people as soon as they are captured. 
The fact that I had my photo equipment with me all along earned me a position in this community that I could fill autonomously. In this sense, I cannot agree with Sontag, for whom photography substitutes experience. In this case, in addition to the essential presence of Danilo, who has been in contact with the Hupd'äh for some time and speaks their language fluently, it was photography that raised the possibility of experiencing this different world and situating myself in it. The field trip instigates a new gaze and photography is a strategic means of recording this perception, which is guided by both defamiliarization and memories. For this visit, photography was also a means of nonverbal communication and sociability with the Hupd'äh, an element of exchange for the welcome they offered me.

As part of this same research I have been conducting as part of a thematic project funded by FAPESP, in July 2011 I spent two weeks in the Bororo village of Tadarimana, together with Edgar Teodoro da Cunha, my former master's and $\mathrm{PhD}$ advisee and current professor at UNESP Araraquara. We took along two films made in 1931 by an ethnographic and zoological expedition connected with the Pennsylvania Museum, in the United States. Having visited the village numerous times before, while doing research work among the Bororo from 1970 to 1997, I was amazed by the changes since my last visit 14 years previously. Memories of the Bororo I had known since 1970 were always there. The photos I took in Tadarimana show that the appearance of the village has changed enormously, now with a lot of garbage strewn about. Financial resources now reach the village regularly in the form of family schooling grants, pensions and wages to an extent I had never seen, so the Bororo now have easy access to consumer goods, which has become a big problem since the village has no garbage collection.

In the course of my two visits, I organized some visual essays on specific topics: electric power supply and how it changed the appearance of the village, introducing technology among the Bororo (cell phones, portable washers, TVs and DVD players, etc.), adaptations and new resources for women's work. The visual essays that are part of this text, with photos taken on this last visit to the Upper Negro River basin include the village and its homes, with some details of construction techniques, such as walls and roofs; gathering and processing peach palms; the cassava civilization, from harvesting crops to ways of preparing different products; some items from material culture, such as making baskets, mortars and pestles; and, finally, children and their play and games. 
It was anthropology that led me to photography rather than vice versa, as is the case of many others who have stood out in visual anthropology. When taking photos among the Hupd'äh, or in Pakistan, or Ethiopia, or many other places, even São Paulo, where sometimes I go out strolling with camera in hand, flanêur style, I realize that my gaze is being directed by the anthropological sensibility (if one may speak of such a thing) I have developed over years of research. Talking about something one does not know very well is difficult. Producing coherent and consistent academic discourse about a little known realm is even more difficult. I would be unable to produce a written analysis of Ethiopia, Pakistan, the Hupd'äh or many other places and people that I have photographed. However, for an anthropologist traveling or strolling around flanêur style with a photo camera in hand, and having a flair for relating to people, an anthropological intuition honed by years of research will leave its mark on the images captured.

Perhaps that is why I see documentary content predominating over expressive aspects in these photos. ${ }^{6}$ Not by accident, subjects that interest me as a photographer are those that have always been of interest to anthropology and that lend themselves to being captured visually. If it is true that images reveal much about the people who produce them, I can understand why I have no interest in taking photos of the "journalistic" or "advocate / agitator" genre (I could have photographed much more garbage in the Bororo village) and I have no talent for artistic photos. Since reaching tenured status as faculty member, I have been working on visual narratives of universes that are dear to anthropology and that interest me personally, since I relate to them on an affective level.

\section{Real and imagined voyages - an overview}

Images of the New World had been produced even before Amerigo Vespucci and Columbus reached the Americas. By showing that reality is constructed by the work of the imagination, Peter Mason (1990) dissolved any dichotomy in this respect. The iconographic tradition of European painting restricted the gaze to familiar things. Observation prompted painters to construct the perceived object in terms of familiar representations. There is a kind of

6 See Rouille, 2009. 
inversion of mimesis in these representations. Instead of making the image fit reality, the latter has to conform to a pre-existing image.

Images and journeys seem to be a constant two-some. Images of the New World, its wildlife, plant life and indigenous peoples began to emerge with the great voyages of the late 15 th and early 16 th centuries. These were not imaginary journeys of the kind found in literature since ancient Greece, which include Odyssey, Sinbad the Sailor, Robinson Crusoe, Gulliver's Travels and, more recently, Planet of the Apes and 2001 - A Space Odyssey, to name just a few imaginary voyages from literature and film. On the other hand, the literary history of imaginary voyages is inconceivable without a parallel history of great voyages of discovery. Conversely, reports of real journeys to an unknown world are always imbued with the imaginary. As George May (1990) notes, there is indeed an organic and historical relationship between real and imaginary journeys. A true-false dichotomy in this respect is inconceivable.

The New World refers to a world not yet registered in tradition, an absolutely "novel" world. Peter Mason (1990) attempts to understand how this new world articulates with domestic European others - witches, Wild Men and Women, madmen and animals - which are features of the European self that cannot be tolerated. In the iconography of Europe's folk culture, the "Wild Man” was seen as a bearded giant carrying a huge cudgel. Mason notes that on meeting Indians on his first voyage, Columbus described them as being ugly in appearance, their very long hair gathered and tied behind, their faces painted with charcoal. A woodcut depicts a scene with King Fernando II in the foreground and a crowd of naked men and women. The men have beards, which contradicts the ethnographic reality, but is consistent with the iconography of the Wild Men whom Europeans thought they would find in the New World.

This New World is seen by Europeans as a source of natural history. Its wildlife and plant life are thus open to description, translation and assimilation. The encyclopedic project of the 16 th century, leading to "scientific curio cabinets" among its most evident expressions, called for a comprehensive inventory of nature and for zoological encyclopedias. As Belluzzo shows, Linnaeus' Systema Naturae (1758) "presented his method of classifying and recognizing plants, animals and minerals, completely transforming the understanding of nature.” According to the method developed by Linnaeus $(1707-1778)$ "the eye is responsible for the first step towards knowledge: the object must first be seen and then named, or introduced in the neutral 
language of science." (Belluzzo, 1994:17). Belluzzo goes further to say that the classical model that Linnaeus adopted presupposes an association between aesthetic taste and scientific knowledge. However, the social behavior of the inhabitants of the New World, beyond purely natural history, remains an obstacle to understanding.

In the reports and iconography produced by explorers and travelers, the imaginary is the ability to depict, and the imaginary structures the entire narrative. In addition to structuring the narrative as such, the constant attendance of the imaginary enables the latter to affect its receptors. The immediate effect is to build an image of Otherness, based on aspects that society rejects in itself.

As Ana Belluzzo also shows in The Voyager's Brazil, "The images produced by these voyagers helped build the identity of Europe. They indicate the manner in which cultures view themselves and others, how they visualize similarities and differences; how they reconcile the subject and the other" (Belluzzo, 1994:13). The author notes that this is a history of points of view, of triangulations of the gaze, in which images reveal the European observer more even than they depict Brazil.

From a similar theoretical perspective, Hartmann (1975) analyzes the iconography of the 18th and 19th centuries and the possibilities of gathering knowledge on Brazilian indigenous peoples from these images, and remarks on the great similarity between graphical representation and language. Both are forms of communication. Both are cultural complexes that, on a first instance, may be described as conveyors of ideas that have dimension as basic difference between them: while language exists in the dimension of time, graphical representation exists in space. Hartmann starts from the SapirWhorf hypothesis that language not only communicates experience but also defines experience for its speakers. The linguistic system in each language is not merely a means of reproducing and expressing ideas; most importantly, it shapes ideas. (Hartmann 1975:18).

Both two authors show that the focal interest of a drawing often reveals more about the ethnocentric view of the artist than the reality observed. A print in Léry's Histoire d'un voyage fait en la terre du Brésil draws the observer's eye to a group of female Indians slashing the victim's body with stone knives; yet, for Tupinambá cultural norms this would be a mere detail, the culminating point being the prisoner's ritual sacrifice. (Hartmann 1975:13) 
As Hartmann shows, on looking at an image, we find a kaleidoscopic flux of impressions that have to be mentally organized - largely by the linguistic system. Similarly, on contemplating any phenomenon, an artist receives a kaleidoscopic flux of impressions that are constantly changing, but on transferring an image onto paper he selects an organized impression of reality, although it is quite confusing in itself, and then transmits the result of this selection. To be able to program visible reality for his audience, the artist also thinks and acts on the basis of categories (idem:18). In this activity of selecting, he is guided by his culture and its categories. For Europeans, bald refers to a man who lost the hair from the top of his skull. The Léry prints depict native Indians as elderly Europeans, and native female Indians like the Venus de Milo whose hips, Hartmann ironically notes, would impede the group's continuity.

Voyager narratives and resulting imagery operate on the basis of rhetorical processes involving the reader, who is seduced by narration or image and becomes an accomplice of the author. Both travel narratives and their imagery have hidden meaning, although it is rather simple and obvious, similar to that of Aesop's fables, or the parables of the Gospel. The unambiguous meaning relates to the itinerary of imaginary or real travelers, which leads the reader to strange and foreign places so that a didactic contrast emerges in the mind. The meaning of the travelers' itinerary comes from the direction of the journey. It is a unique sense (sens unique) rather than a double one. Text and images highlight relative aspects where a reader would tend to see the absolute.

\section{Persian Letters - voyages in reverse}

When the direction of travel is reversed, meaning becomes double. Montesquieu's Persian Letters was undoubtedly the first paradigm for these imaginary journeys or voyages in reverse. Instead of moving away from society itself, Usbek and Rica set out from distant Isfahan to travel in Western Europe from 1710 to 1720 , and that is where most of the letters in the book were written. Note that the letters correspond to the prototype of verbal messages. A letter delivered demands the attention of its recipient.

Reversing the itinerary leads to a reversal of perspective. In imaginary voyages of the classical genre, or even reports of real centrifugal travel, from the known to the unknown, the traveler belongs to the same culture as the reader, who identifies with him. In the imaginary voyage of this new 
centripetal model, the character with whom the reader is more likely to identify is the very object of the gaze and of the foreign tourist's observation. Therefore, subject is metamorphosed to object.

By reversing the classic voyages, the objectivity derived from contrasting two cultures is enhanced. Similarly, this reversal affords an alteration in the lens through which we perceive the Other. Persians are exotic for the French, but not for themselves.

The imaginary voyage model also affords a satire of Western customs and an evocation of Asian habits. None of the charm - of seeing new places, new horizons, and getting away, as one of the most appreciated qualities of this type of story - is lost. Montesquieu has his characters receive letters from their eunuchs and their wives kept in their harem in Isfahan. Knowledge of oneself necessarily involves knowledge of the other, on both the individual and the group level.

Accounts of voyages in the 15th and 16th centuries, as well as the imaginary voyages of the 18th century, show that there is more to them than the aim of exploitation and loot, propagation of the faith, or tourism. Exchange and knowledge are also objectives - in a double, rather than a single direction.

Persian Letters was published in 1721, when Montesquieu was 32 years old, six years after the death of Louis XIV. These 161 letters are undoubtedly the first paradigm of these imaginary reverse voyages. As Renato Janine writes in a foreword to a recent Portuguese edition of Persian Letters, novels written in the form of letters in the 18th century have a very rich structure. "They seem to augur an art form as modern as cubism, in so far as they expound the same story from different angles; rather like the open work so widely celebrated in literature today." Instead of the omniscient narrator, a succession of agents is what there is.

The 18th century was marked by an extraordinary interest in the East. A French translation of the Thousand and One Nights, in a moralized expurgated edition, started to appear in 1704. Westerner's fantasies about the East involved sexual desires and refinements in particular. Montesquieu had read the story of two Frenchmen who traveled to Persia. Yet, most of what he says is pure imagination, he mentions Persians mostly to criticize what is taking place in France.

7 As a footnote, let us recall that this same inversion used by Montesquieu appears in at least one anthropological article of which I am aware: Horace Miner's 1973 article, "Body Ritual Among the Nacirema". 
According to Todorov (1989), the Letters emphasizes the belief that a society may only be understood when one is not part of it, or was not born into it. Understanding or knowing the world is in some way to renounce living in it, but in addition to the status of a foreigner, a burning desire for knowledge is required. However, we know that Montesquieu, rather than the fictitious Usbek and Rica, is the one who takes time to peruse European society. To this end, Montesquieu had to move away from himself and take a detour through Persia, as a sort of forerunner of anthropological journeys. The comparative method relativizes customs, and the author's fictional style avoids being judgmental. The characters show a relativistic tolerance in terms of politics and religion.

What the reports and imagery of these voyages enable us to grasp, whether they be real or imagined journeys, is that in all systems of otherness there is a play between principles of inclusion and exclusion, which together provide the rules for interaction. In this respect, systems of otherness are also structures of identity and difference, much more related to establishing one's own identity than the empirical reality of the other. These assumptions enable us to take a first step toward understanding the reason for this constant pairing of voyages and images; and, as we shall see, one of the reasons that prompt anthropologists to travel and produce images. Voyages lead to this encounter with the Other, a classic theme for anthropology ever since the discipline was founded - an encounter that is also permeated by the imaginary. Voyages are conducive to the production of images and the latter, in turn, much more than text, have enormous powers in terms of metaphor, synthesis and synesthesia. Moreover, images as visual signs "may be more important in defining people in relation to oneself than in relation to each other. The visible emphasizes what one is not" (MacDougall, 1997:280).

\section{Travel as exercises of the gaze and the resultant images - some considerations in conclusion}

Accounts of exploration voyages - and we have many such accounts in Brazil's history, beginning with Caminha's first letter to King Manuel of Portugal, Hans Staden's voyage, Alexandre Rodrigues Ferreira's philosophical journey to the Amazon (1783-1792), and many others - are closely related to images and cartography. The report speaks, while images depict landscapes, 
physical types, cultural scenes, the space crossed. The traveler plows the landscape and traces the paths of knowledge and imagination, where boundaries are indeed ambiguous. There are several reasons for the ambiguity: previous experiences may interfere with images, the imaginary is always present, and, in relation to print illustrations in the works of travelers, we know that there are differences between the artists' originals and the published illustrations, which may be more sensitive to the demands of the readership as Hartmann explains at length (1975).

Men in all societies resort to symbolic representations to produce schematic plans for their occupation of space and configuration of their relationship with the world. There are many different ways of schematizing occupation of space. I myself have recorded what I called an ethno-cartography: a Bororo chant performed at the end of mourning, when the hunter who represents the deceased hands over the hide of a jaguar to the intoner. With the hide wrapped around his body, he lists geographical features of the land while gradually turning around and around while pointing to markers of traditional territory. ${ }^{8}$ Mythical accounts related in Genesis attest to this human need to tame time and space. Queen, chess, hopscotch, mazes, hidden-treasure maps, and a wide range of calendars are found in the folklore of different societies.

On a voyage, we add new landscapes to our existence, live a different experience of temporality, and interrogate that which is familiar to us. “... travelers become distant because they differentiate and transform their world [...] voyages are always undertaken in time", says Sergio Cardoso (1988:358). A journey is accompanied by defamiliarization and this is what encourages us to look and imagine. Through these voyages, we differentiate our own world. That is why field trips are also a common resource for the activity of the anthropologist and certainly occupy a special place in the discipline. Many refer to their first trip as a rite of passage. Countless reports of these periods have been published by anthropologists, some in journal form (Ribeiro, 1996), others as reflections on the experience of being immersed in a different universe (Barley, 1983; Maybury-Lewis, 1965), while yet others combine reports of their personal life with an ethnographic description of the realm observed (LéviStrauss, 1955; Grimshaw, 1992). However, anthropologists' written reports of their journeys are better known than the photographs they surely took.

8 See Caiuby Novaes, 1998. 
Tristes Tropiques is a key feature in the education of many anthropologists. It took 20 years before an account of Lévi-Strauss' 1935 journey in Brazil was published in Tristes Tropiques, but Saudades do Brasil was not published until 1994 and is less well known than the book. Darcy Ribeiro's photographs were shown by the Native Indian Museum after his death and long after his written reports of his stay with the Urubu-Kaapor from 1949 through 1951. We have reports of Anthony Seeger's fieldwork among the Suyá, David MayburyLewis among the Xavante, Nigel Barley among the Dowayo in Cameroon, Anna Grimshaw among women in a monastery in the Himalayas. Surely they all took photographs, but very few images are available.

We know that throughout the period of evolutionism, the use made of images by anthropology was very similar to that of biology and botany, i.e., restricted to illustrative and classificatory uses in these three disciplines. Today images are increasingly used in knowledge fields such as physics, geology, crystallography, chemistry and the conjunction of biology with nanoscale research, where they emerge as data sources for research topics. ${ }^{9}$ Seen as "robust and accurate descriptions" that provide information about the core role of relationships within and between phenomena, images are crucial for these areas of knowledge, since they present a synthesis of interconnected objects. (Marcovich and Shinn, 2011:231; 237; 243). Also in these knowledge fields “...images may be viewed as entering into a kind of dialog with one another, and through this interaction, relevant aspects of phenomenon may be observed" (idem: 260). ${ }^{10}$

However, issues arise when using images to reach analytically satisfactory conclusions. Marcovich and Shinn summarized three types of difficulties, as follows: 1) there is overabundant information and the visual field is perceived as chaotic and impossible to interpret; 2) denaturalization of the images - which may be manipulated by introducing colors, for example - is seen as a constant danger, raising questions as the authenticity of an image (issue already alluded to, which has been present from the beginning of photography); and 3) Which items of the image should be selected as providing information relevant to the question investigated?

9 See Marcovich, A. and Shinn, T., 2011.

10 Looking at my collection of about 3,0oo photos taken in the course of many field trips to the Bororo, and arranging them in series, I realized that the naming ritual is, in structural terms, an inverted analogue of the funeral rite. For more details see Caiuby Novaes, 2008. 
Nevertheless, many scientists interviewed by Marcovich and Shinn admitted that "images are more satisfying psychologically [...] they lie closer to a kind of instinctive understanding" (idem, 243).

Among anthropologists, of course, there is little use of images, but uses are nonetheless very varied. There is an aesthetic sense in Lévi-Strauss' shots, despite his not attaching great value to photography.11 His photos do not relate to the text and even in Tristes Tropiques, they are part of a separate booklet and hardly ever referenced in the text. A very different approach to the use of photography is found in Malinowski's monographs, which constantly relate to his ethnographic description, as rightly noted by Samain (1995). Unlike Malinowski, Lévi-Strauss had handled a photo camera while assisting his father, who was a painter, and he had full mastery of the device. But it was Malinowski who set great store by photos as part of ethnographic descriptions, and his journals make frequent mentions to taking photos, with increasing use of photos in his papers, and constant references to them in his writings.

Malinowski used his photos in a manner very similar to current scientists working in the so-called "hard sciences", for whom the key aspect in epistemological terms is what Shinn and Marcovich called image/argument. If science requires intelligibility, it is in joining naturalized images with the arguments that explanation and intelligibility originate. For these scientists, and I would say for anthropologists too, images are a source of information and a factory for turning out new questions. They are "they are reactive to demands stemming from argument and, reciprocally, arguments change in response to exigencies issuing from images" (idem: 262). On comparing the uses of text and image and their different competencies, one may find that "The visual media make use of principles of implication, visual resonance, identification and shifting perspective that differ radically from the principles of most anthropological writing. They involve the viewer in heuristic processes and meaning creation quite different from verbal statement, linkage, theory formation and speculation. [...] Above all the visual media allow us to construct knowledge not by 'description' but by a form of 'acquaintance”. (MacDougall, 1997:286).

11 I have analyzed the relationship between Lévi-Strauss and photography elsewhere (Caiuby Novaes, 1999). 
As noted above, photographs and exploration voyages are constantly paired, and I would like to point to one last reason for this pairing when it comes to anthropologists' field trips. Through their aesthetic and sensitive construction, images help to show that the anthropologist "was there", and in this respect complement "the delicate but successful establishment of a familiar sensibility, much like our own, in an intriguing but unfamiliar place, not at all like our own ". (Geertz, 1988:16)

What do we frame in travel images, to return to da Matta's epigraph and conclude this text? I think photos taken by traveler anthropologists frame what they see, what actually touches them. This seems to be an obvious assertion. Yet I would like to emphasize that I refer to guided observation that starts from a very specific gaze, a trained sensitivity, a learned intuition. These photographs are a way of ordering observed reality. At the same time, they reveal not only the more subjective relationship of the photographer with content of what he is showing in his photos, but also how he relates to this language.

\section{Bibliographical references}

BARLEY, Nigel. 2000. The innocent anthropologist, notes from a mud hut. Illinois: Waveland Press.

BELLUZZO, Ana Maria de Moraes. 1995a. The voyager's Brazil, volume IImagery of the New World. São Paulo: Metalivros; Fundação Odebrecht.

BELLUZZO, Ana Maria de Moraes. 1995b. The voyager's Brazil, volume II - A place in the universe. São Paulo: Metalivros; Fundação Odebrecht.

CAIUBY NOVAES, Sylvia. 1998. "Paisagem bororo - de terra a território". In: Ana Maria Niemeyer;Emília Pietrafesa de Godoi (orgs.), Além dos territórios. Campinas: Mercado de Letras. pp. 229-269.

CAIUBY NOVAES, Sylvia. 1999. "Lévi-Strauss, razão e sensibilidade". Revista de Antropologia, $42(1$ and 2): 67-77.

CAIUBY NOVAES, Sylvia. 2008. “Corpo, imagem e memória”. In: L. E. Mammi; L. Schwarcz (org.), 8 x fotografia. São Paulo: Companhia das Letras. CARDOSO, Sérgio. 1988. "O olhar viajante (do etnólogo)". In: Adauto Novaes (org.), O olhar. São Paulo: Companhia das Letras.

CASTRO, Silvio. 1985. A carta de Pero Vaz de Caminha. Porto Alegre: L\&PM Editores. 
FERREIRA, Alexandre Rodrigues. 2005. Viagem ao Brasil. Coleção Etnográfica. Petrópolis: Kapa Editorial.

GEERTZ, Clifford. 1988. Works and lives: the anthropologist as author. Stanford: Stanford University Press.

GRIMSHAW, Anna. 1992. Servants of the Buddha - winter in a Himalayan convent. London: Open Letters.

HARTMANN, Thekla. 1975. A contribuição da iconografia para o conhecimento de índios brasileiros do século XIX. Coleção Museu Paulista vol.1. São Paulo: Edição do Fundo de Pesquisas do Museu Paulista da Universidade de São Paulo.

LÉVI-STRAUSS, Claude. 1955. Tristes tropiques. Paris: Librairie Plon.

LÉVI-STRAUSS, Claude. 1994. Saudades do Brasil. Paris: Librairie Plon.

MACDOUGALL, David. 1997. “The visual in anthropology”. In: Howard Banks and Marcus Morphy (orgs.), Rethinking visual anthropology. New Haven: Yale University Press. pp. 276-295

MARCOVICH, Anne \& SHINN, Terry. 2011. "Structures and functions of images in science and in art: between synthesis and holism of form, force and perturbatio". Scientice Studia, Revista Latino-Americana de Filosofia e História da Ciência, 9(2): 229-265.

MASON, Peter. 1990. Deconstructing America - representations of the other. London and New York: Routledge.

MAYBURY-LEWIS, David. 1965. The savage and the innocent. Boston: Beacon Press.

MAY, Georges. 1990. "Sens unique et double sens - réflexions sur les voyages imaginaires”. In: Diogène Paris: UNESCO et Conseil International de la Philosophie et des Sciences Humaines · p.152.

MINER, Horace. 1973. "Body ritual among the Nacirema”. In: A. K. Ronney; P. L. De Vore (orgs.), You and others: readings in introductory anthropology. Cambridge: Winthrop Publishers. pp. 72-76.

MONTESQUIEU. 1964 [1721]. Lettres persanes. Paris: Garnier-Flammarion. MORRIS, Errol; WESCHLER, Lawrence. 2012. "Believing is seeing”. Zum, biannual magazine on photography, 2: pp. 122-135 São Paulo: Cosac\&Naify and Instituto Moreira Salles.

PAIVA RAMOS, Danilo. 2011. A ferida dos astros: histórias dos Hupd'äh de ipadu. FAPESP, Report, Mimeo.

RIBEIRO, Darcy. 1996. Diários índios: os Urubus-Kaapor. São Paulo: Companhia 
das Letras.

ROUILLÉ, André. 2005. La photographie. Entre document et art contemporain. Paris: Gallimard.

SAMAIN, Etienne. 1995. “'Ver' e 'dizer’ na tradição etnográfica: Bronislaw Malinowski e a fotografia”. Horizontes Antropológicos, 2: 19-49.

SEEGER, Anthony. 1980. Os índios e nós - estudos sobre sociedades tribais brasileiras. Rio de Janeiro: Ed. Campus Ltda.

SEVERI, Carlo. 2011. "L'espace chimérique. Perception et projection dans les actes de regard". In: "Pièges à voir, pièges à penser. Présences cachées dans l'image", Carlo Severi (coord.). Gradhiva. Revue d'anthropologie et d'histoire des arts, 13: 8-47.

SONTAG, Susan. 1977. On photography. New York: Picador USA.

STADEN, Hans. 1974. Duas viagens ao Brasil. Belo Horizonte: Ed. Itatiaia/ São Paulo: Ed. da Universidade de São Paulo - EDUSP.

TODOROV, Tzvetan. 1992. The conquest of America: the question of the other. New York: Perennial.

TODOROV, Tzvetan. 1989. Nous et les autres: la réflexion française sur la diversité humaine. Paris: Seuil. Cap. "Lettres Persanes” (pp. 389-401).

\section{About the author}

Sylvia Caiuby Novaes is chair professor in the Anthropology Department of the University of São Paulo - USP, at which she coordinates the Sound and Image Lab in Anthropology - LISA. She has published extensively on the indigenous societies of Brazil (The Play of Mirrors - The Representation of Self Mirrored in the Other, published in English by the University of Texas Press and also in Portuguese) and on the relations between anthropology and image. Her article "O Brasil em imagens: caminhos que antecedem e marcam a antropologia visual no Brasil” [Brazil in Images: Paths that Precede and Punctuate Visual Anthropology in Brazil] integrates the collection edited by ANPOCS. Email: scaiuby@usp.br

Translated from Portuguese by Izabel Murat Burbridge.

Received April 30, 2012, approved for publication 30 June, 2012 
Alto Rio Negro February 2012

Sylvia Caiuby Novaes 


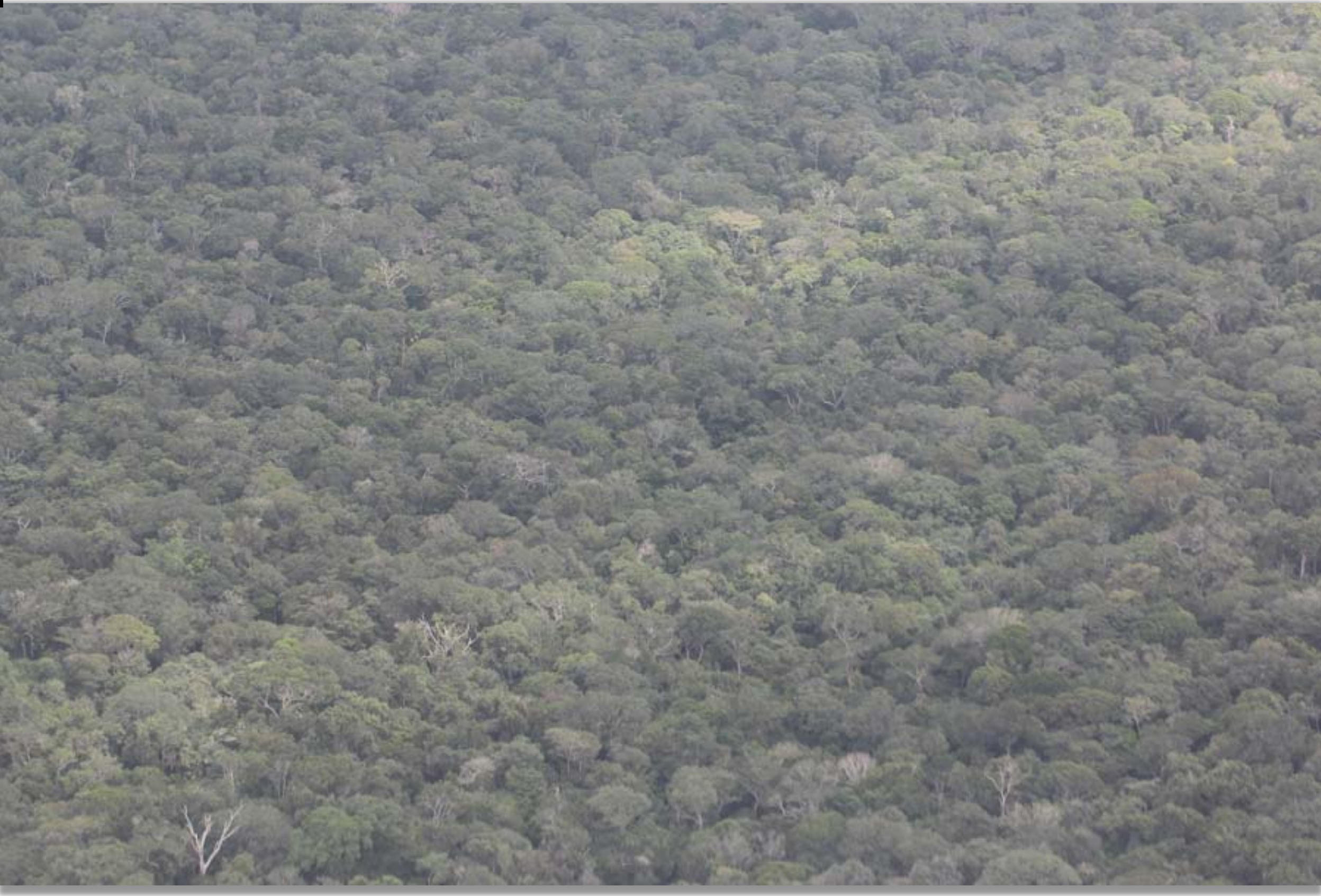

Amazon Forest, aerial view 


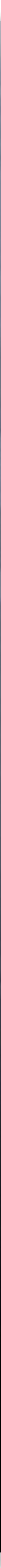





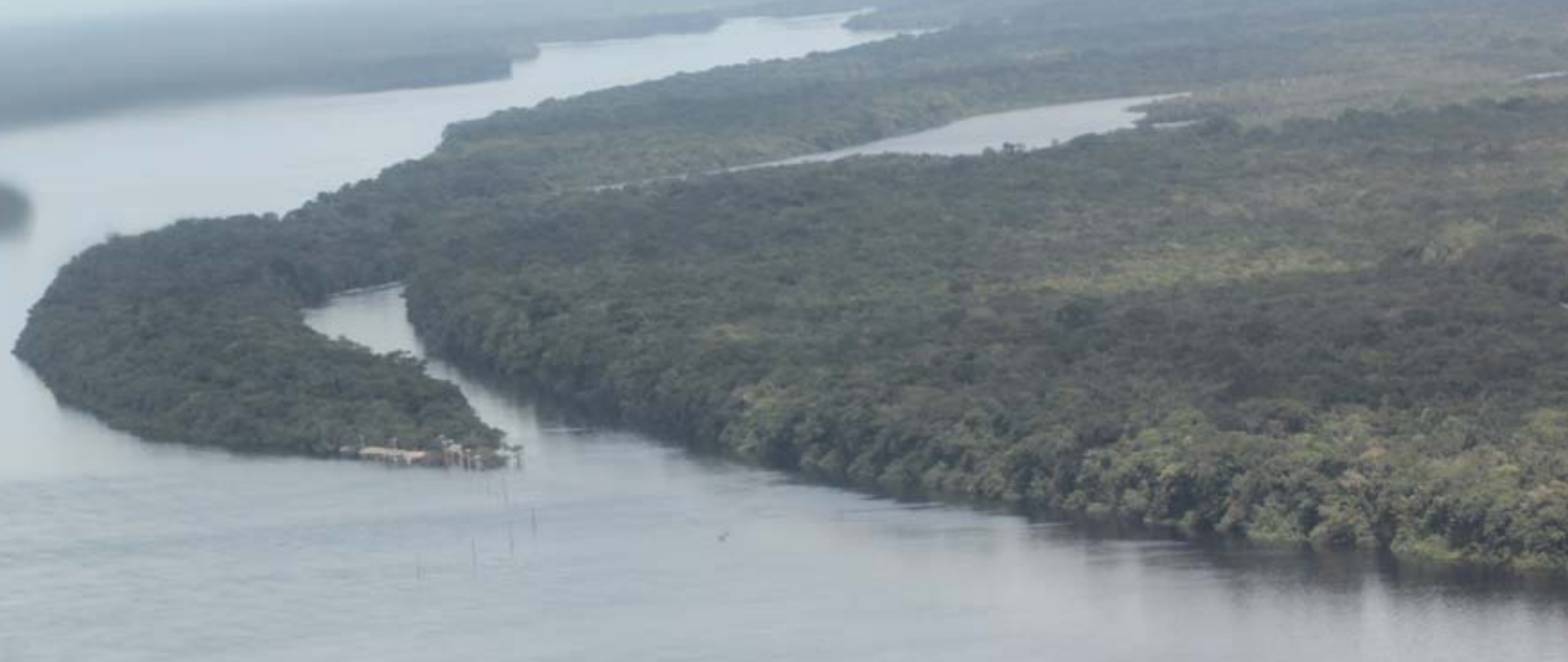




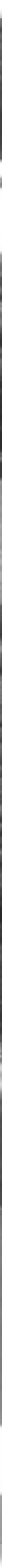

Barcelos, AM - aerial view 
-
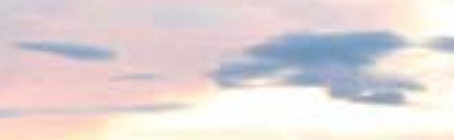

\section{$-3=$}
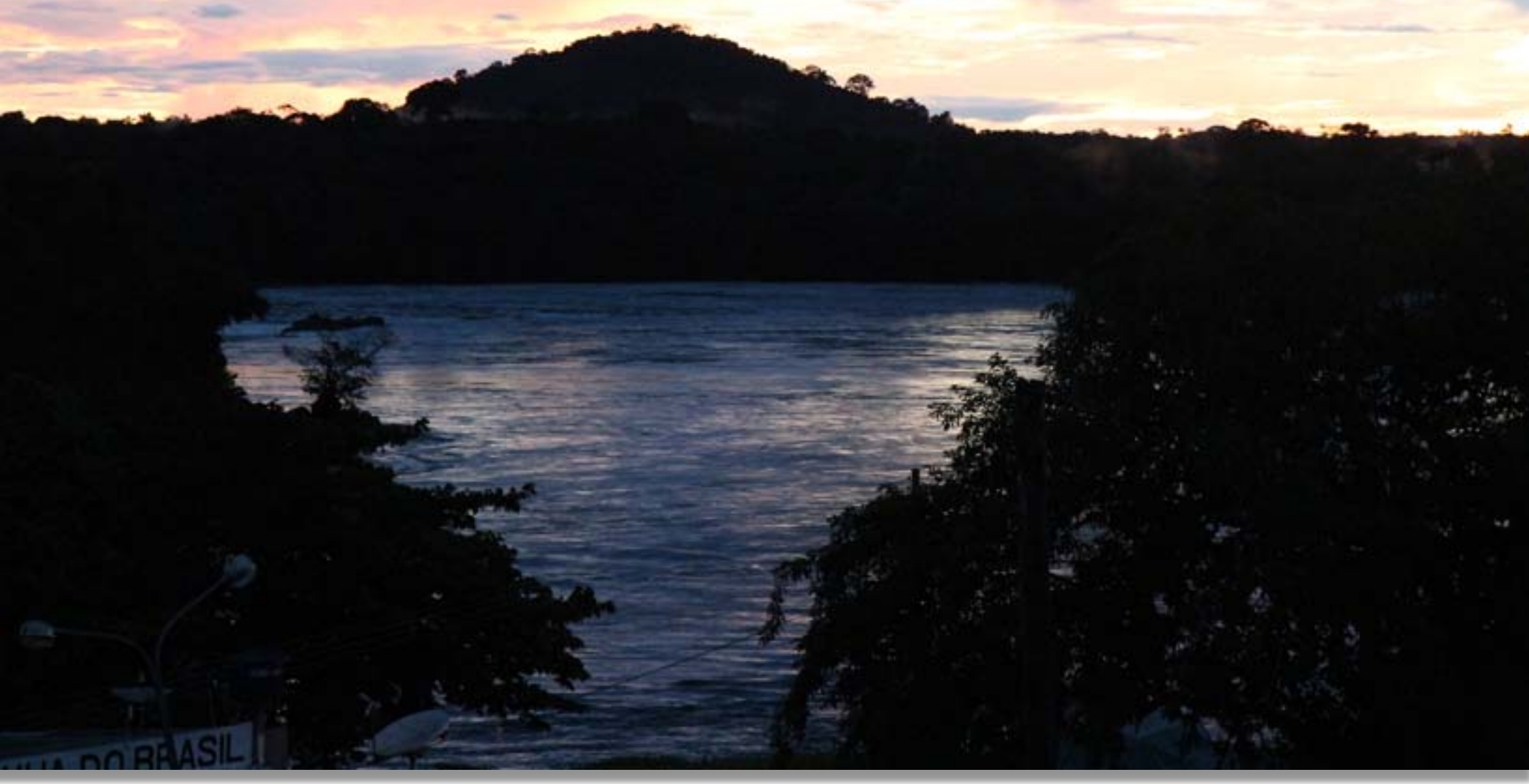

Alto Rio Negro 


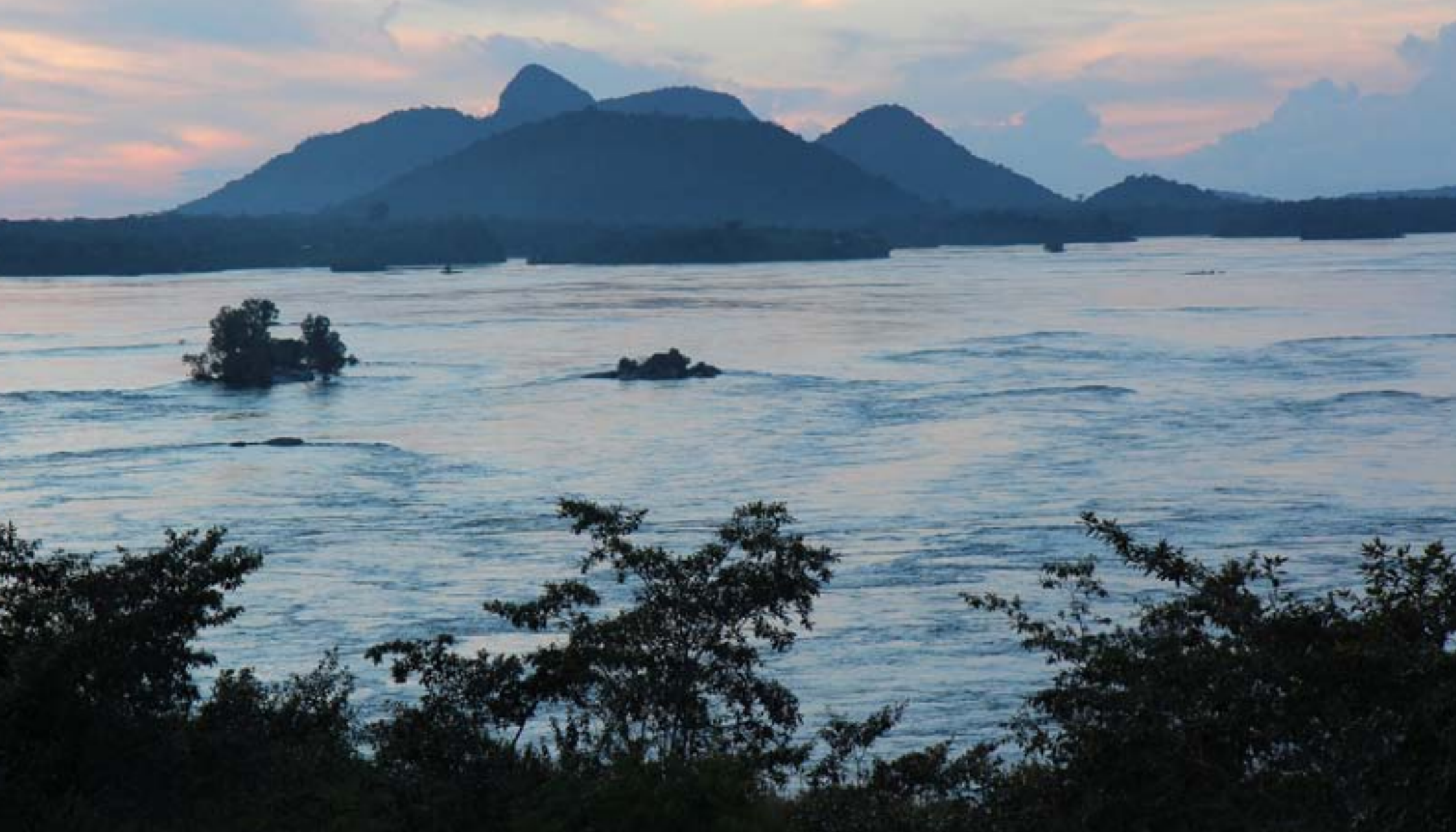

Serra da Bela Adormecida 


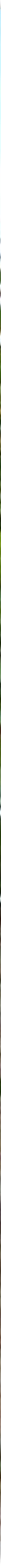

Instituto Socioambiental in São Gabriel da Cachoeira - AM 


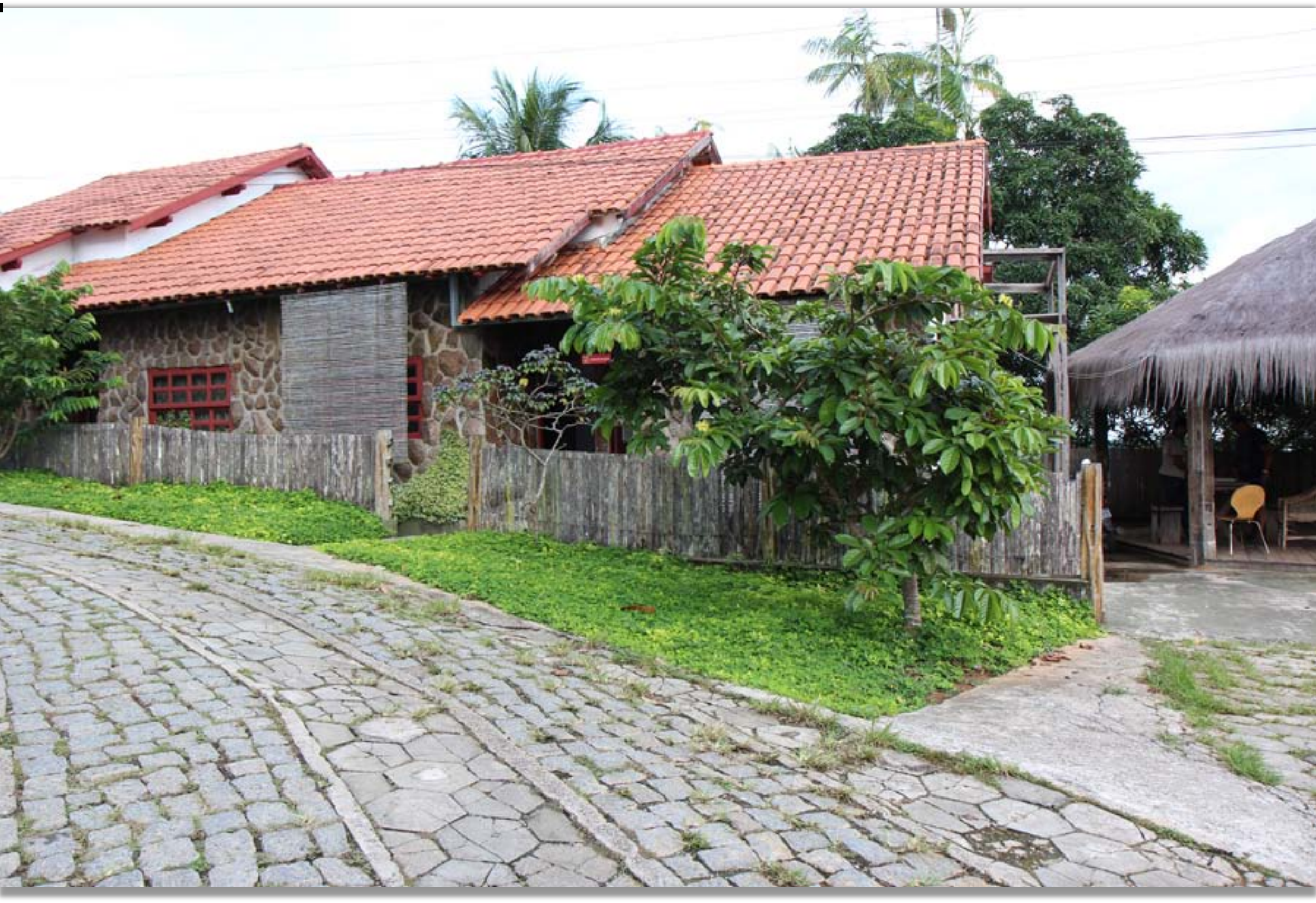




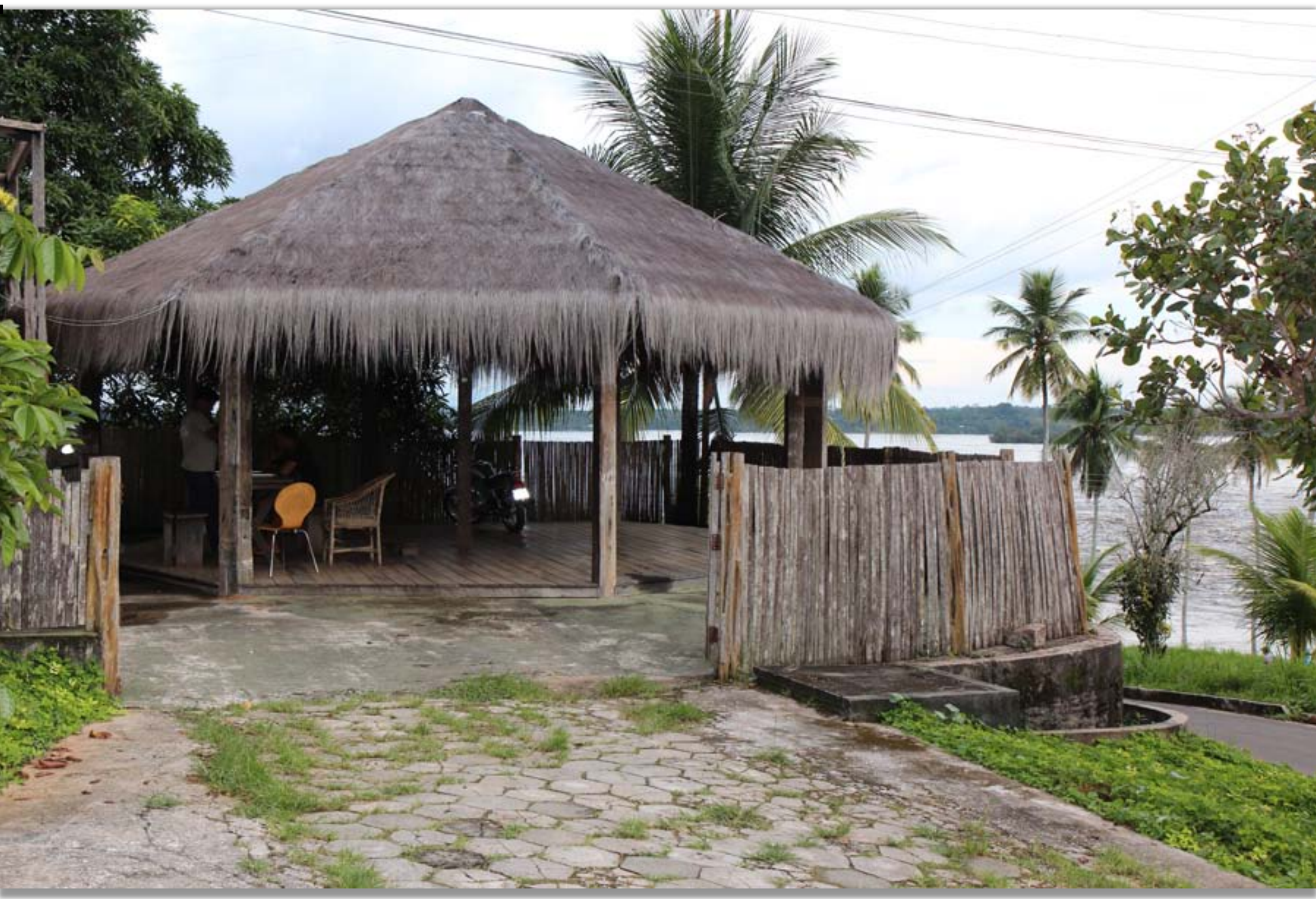




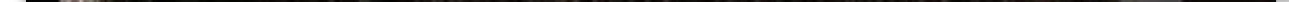




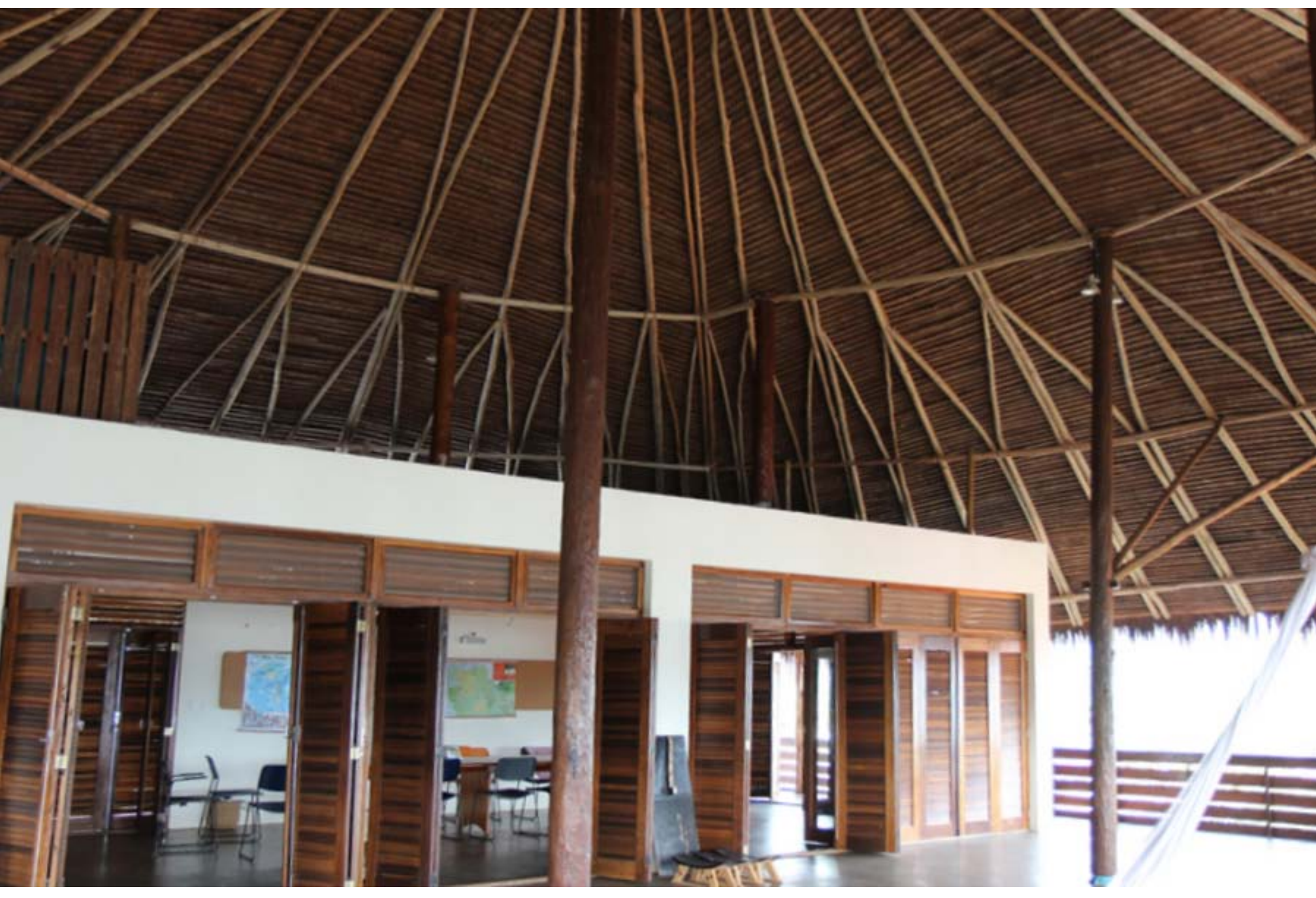




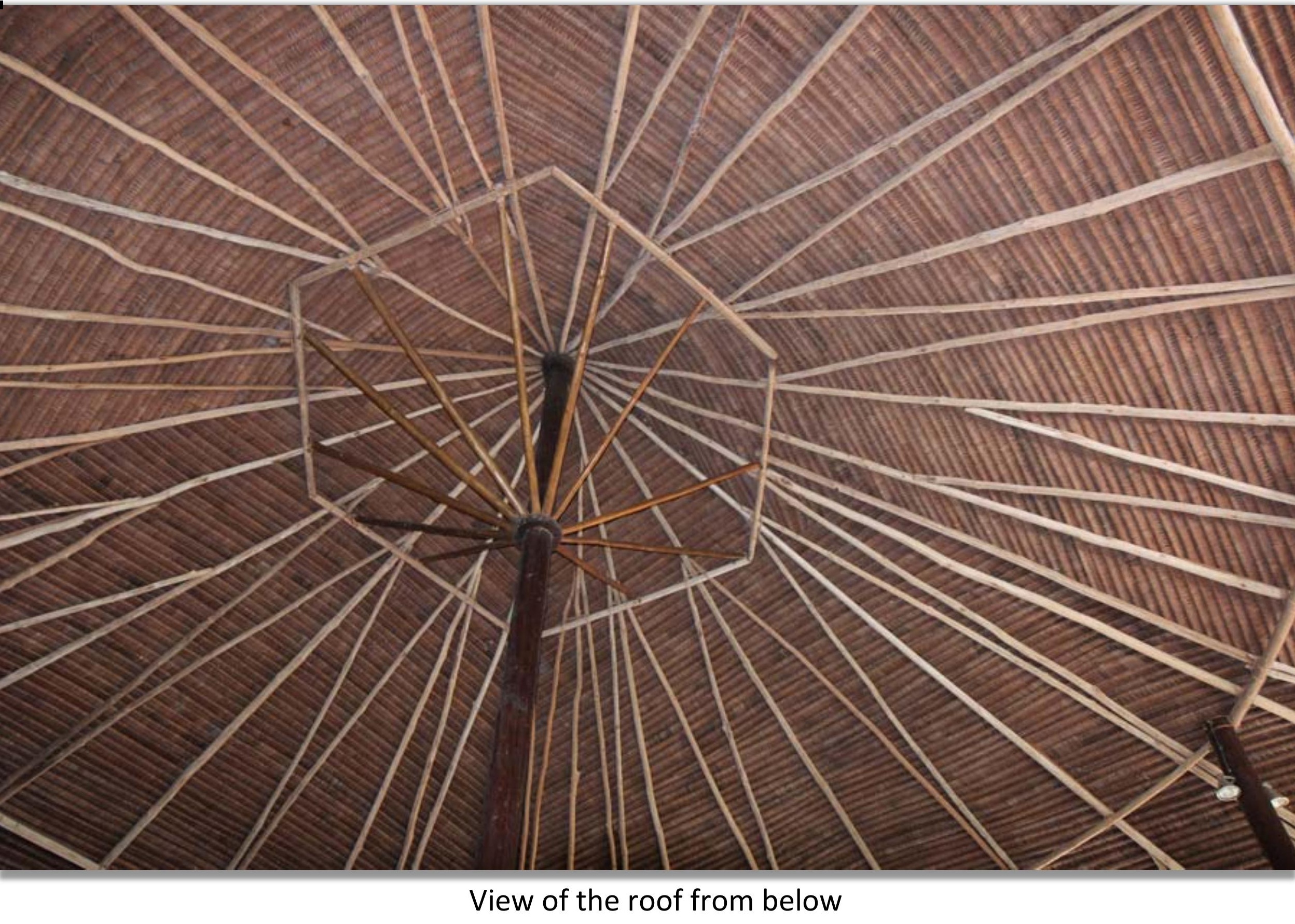




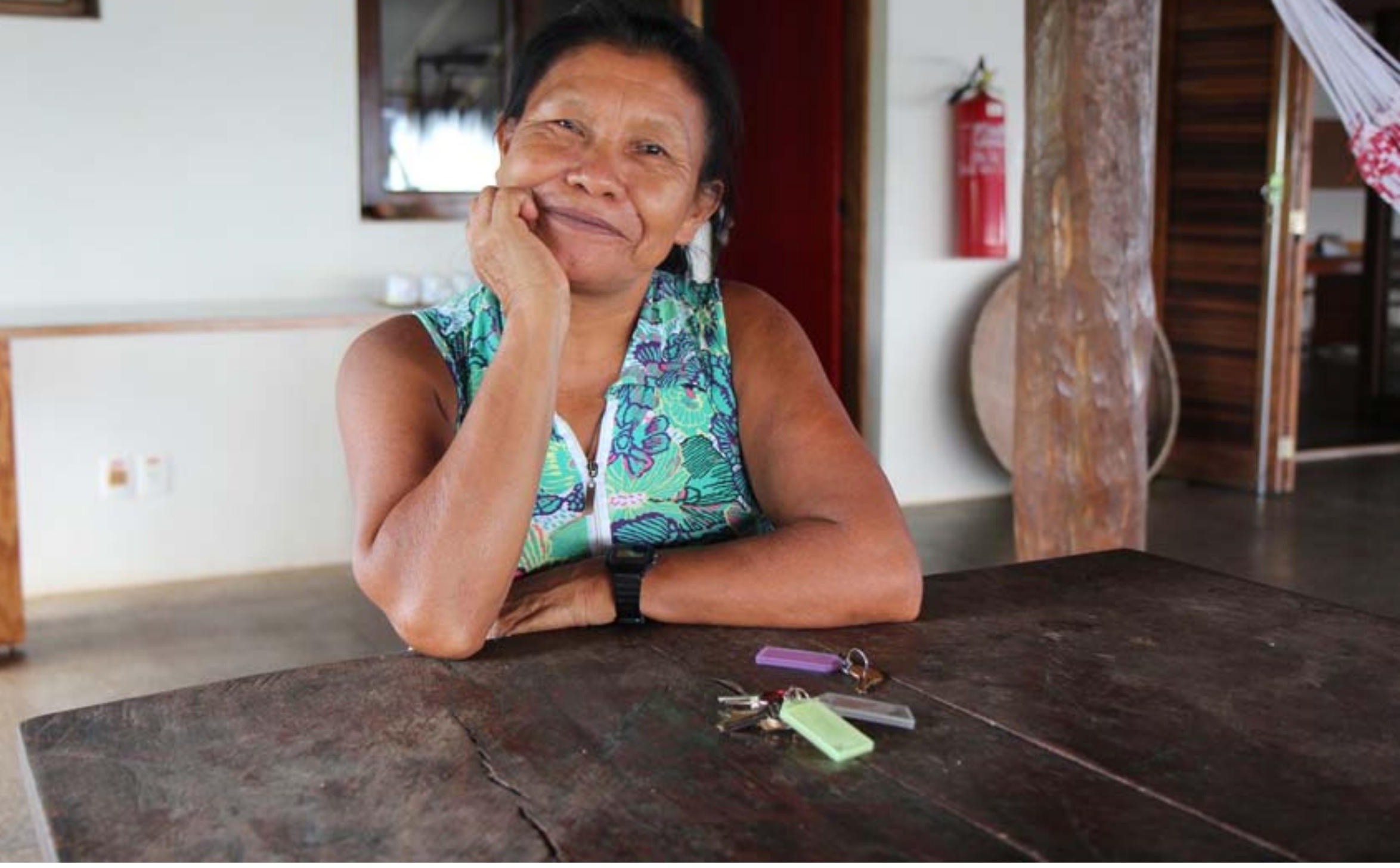

Dona Margarida is responsible for the good food we ate at ISA 


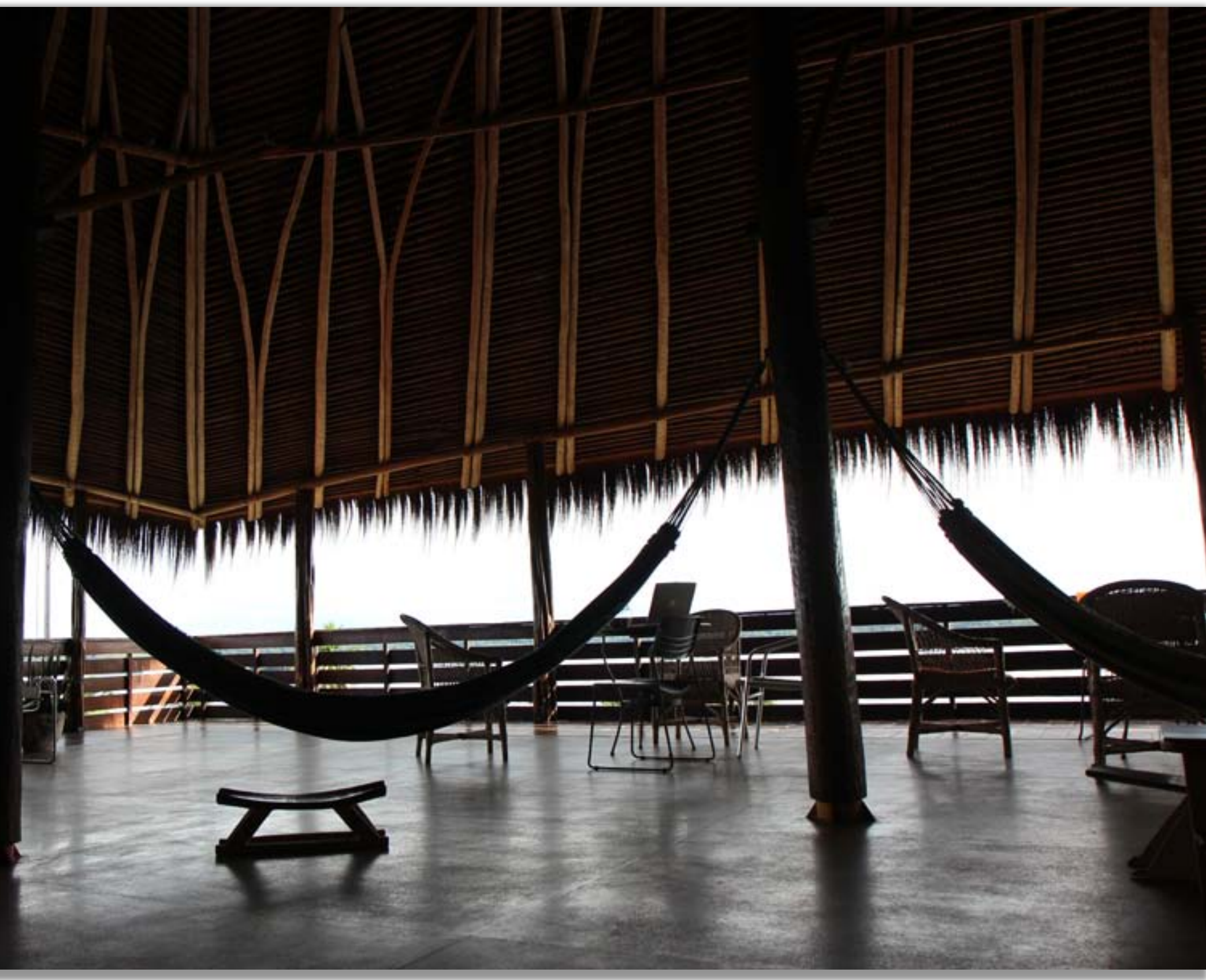




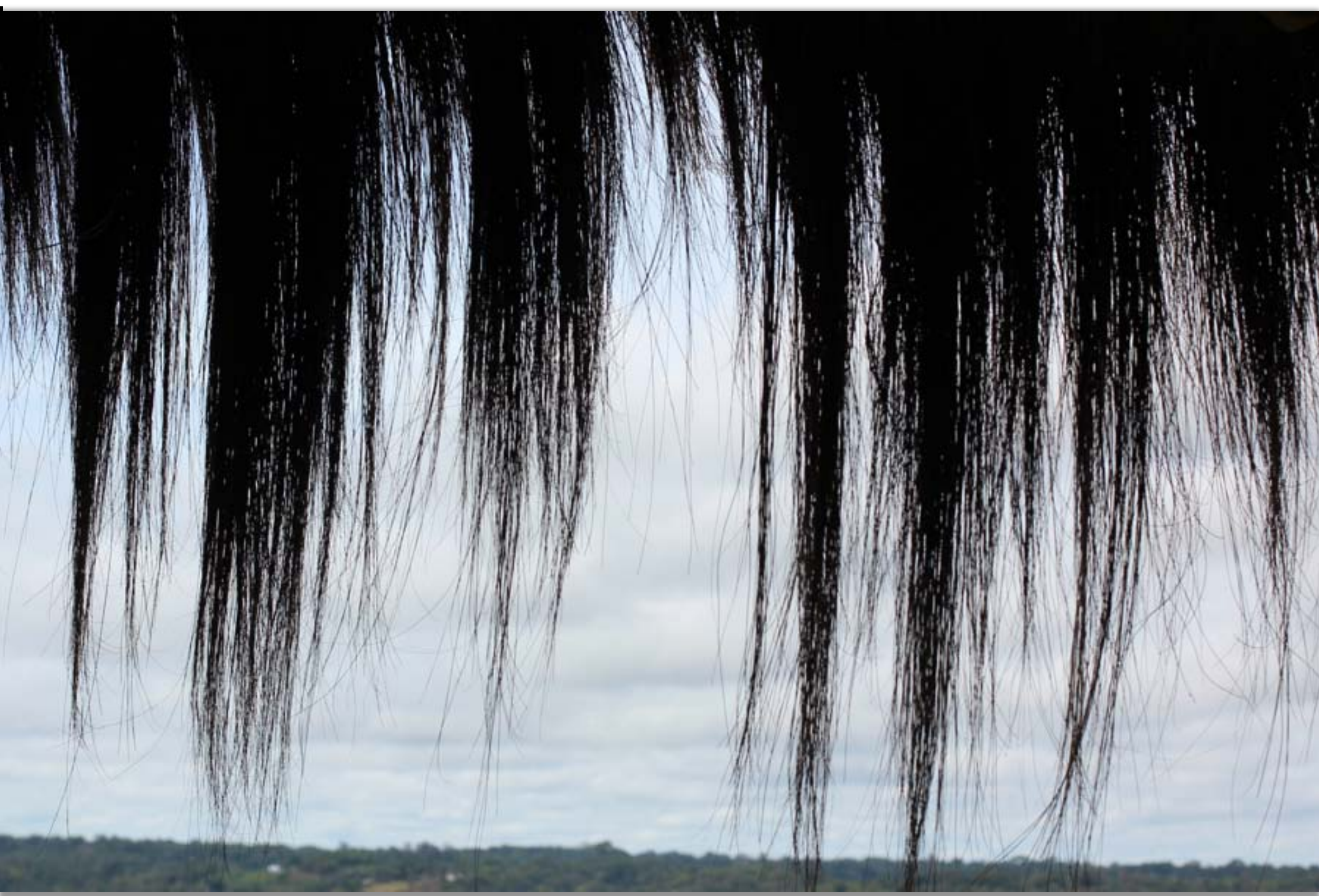



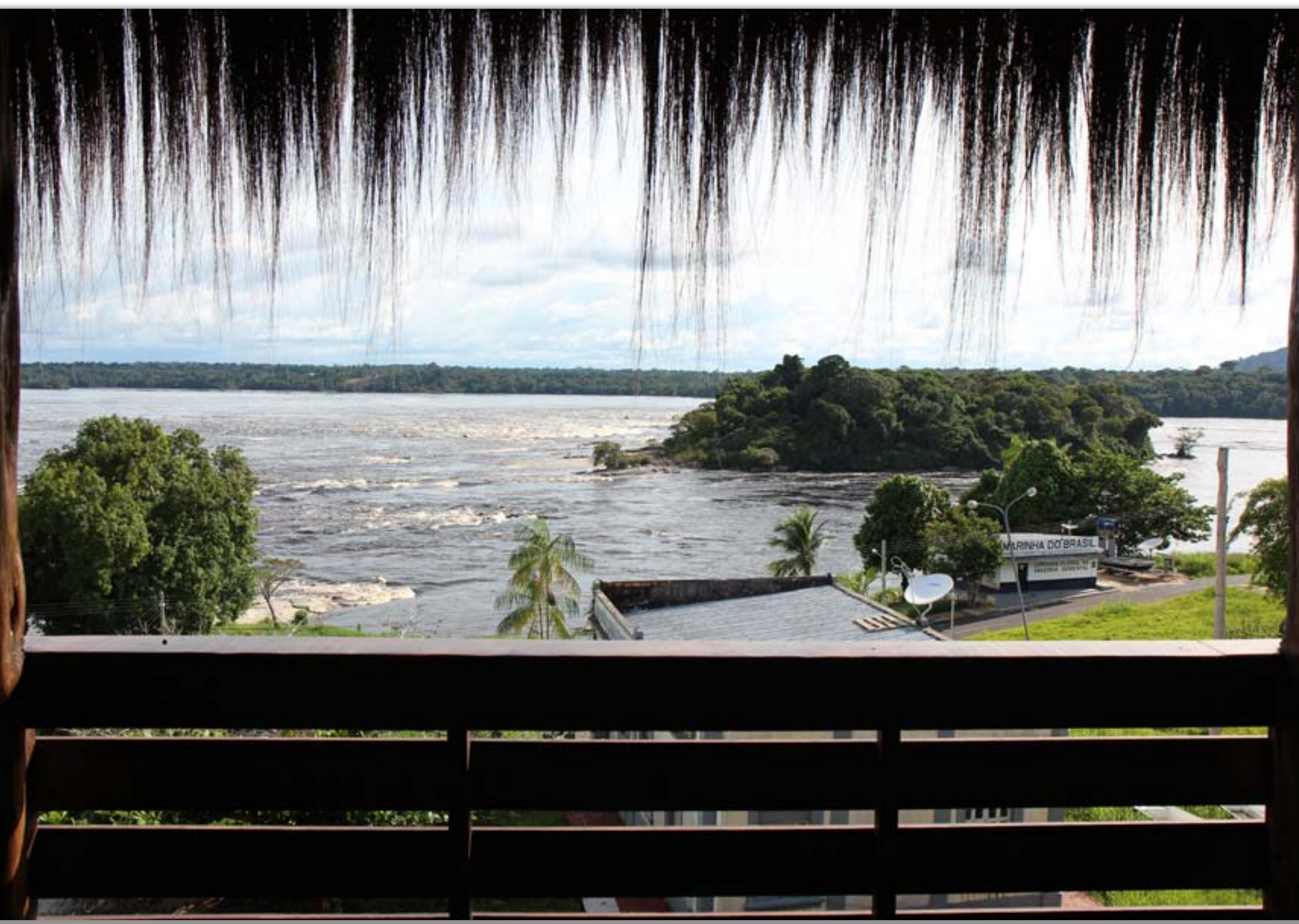

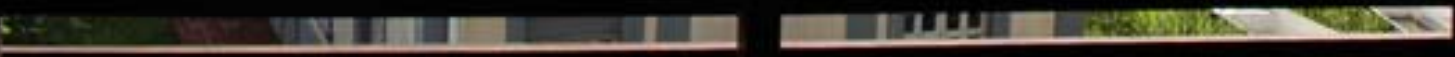




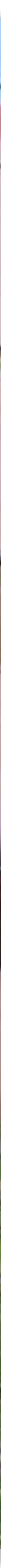

City center, São Gabriel da Cachoeira, AM 
THE TRIP

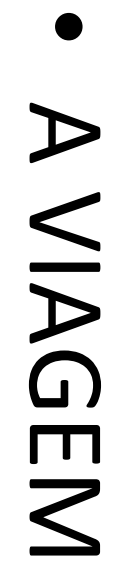




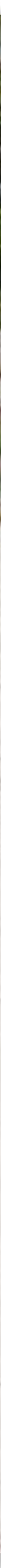

It takes two days in this boat to go from São Gabriel da Cachoeira to the Hup'däh village 


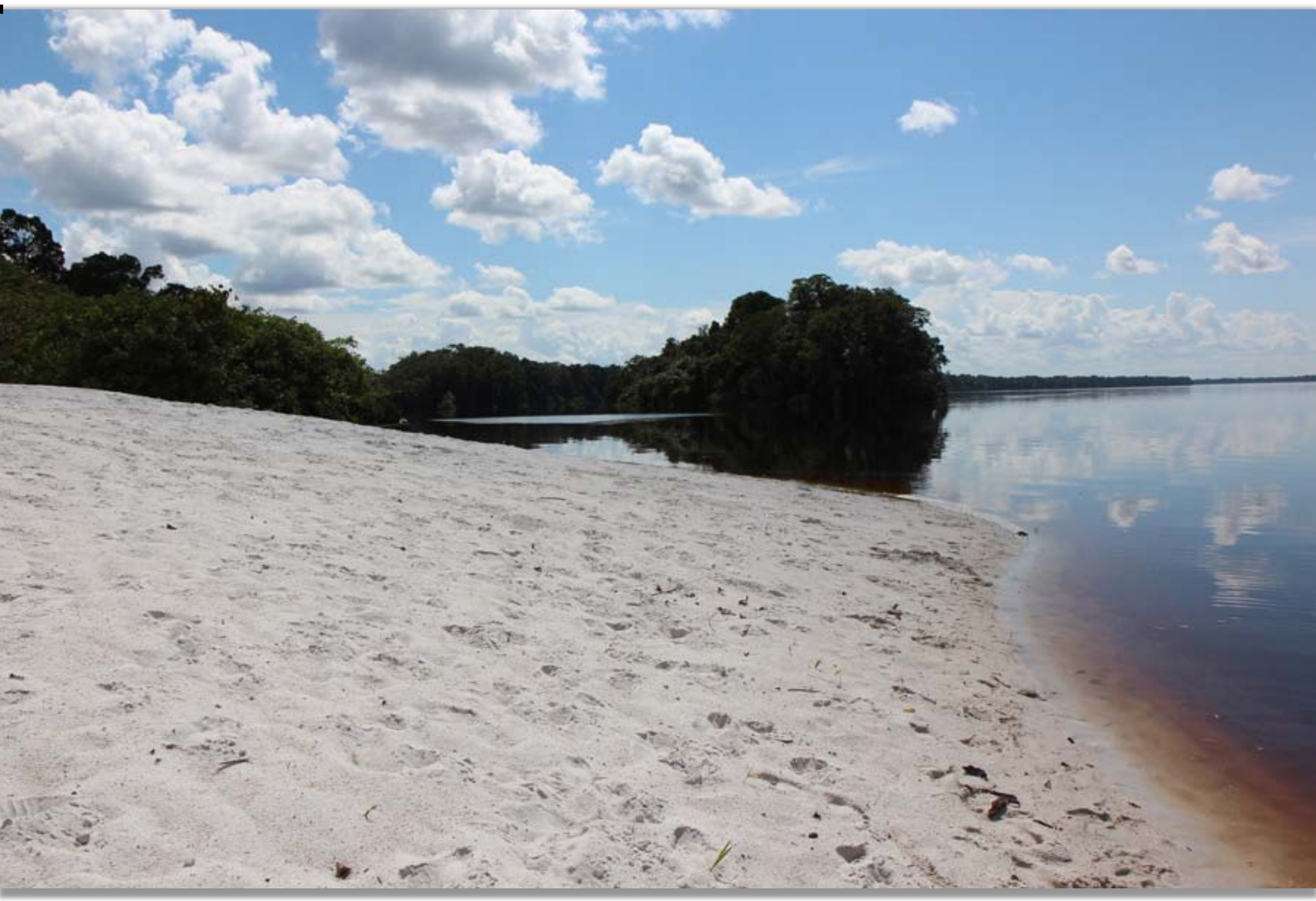

A harbor in Uaupés River, near Monte Alegre, formerly known as Matapi 


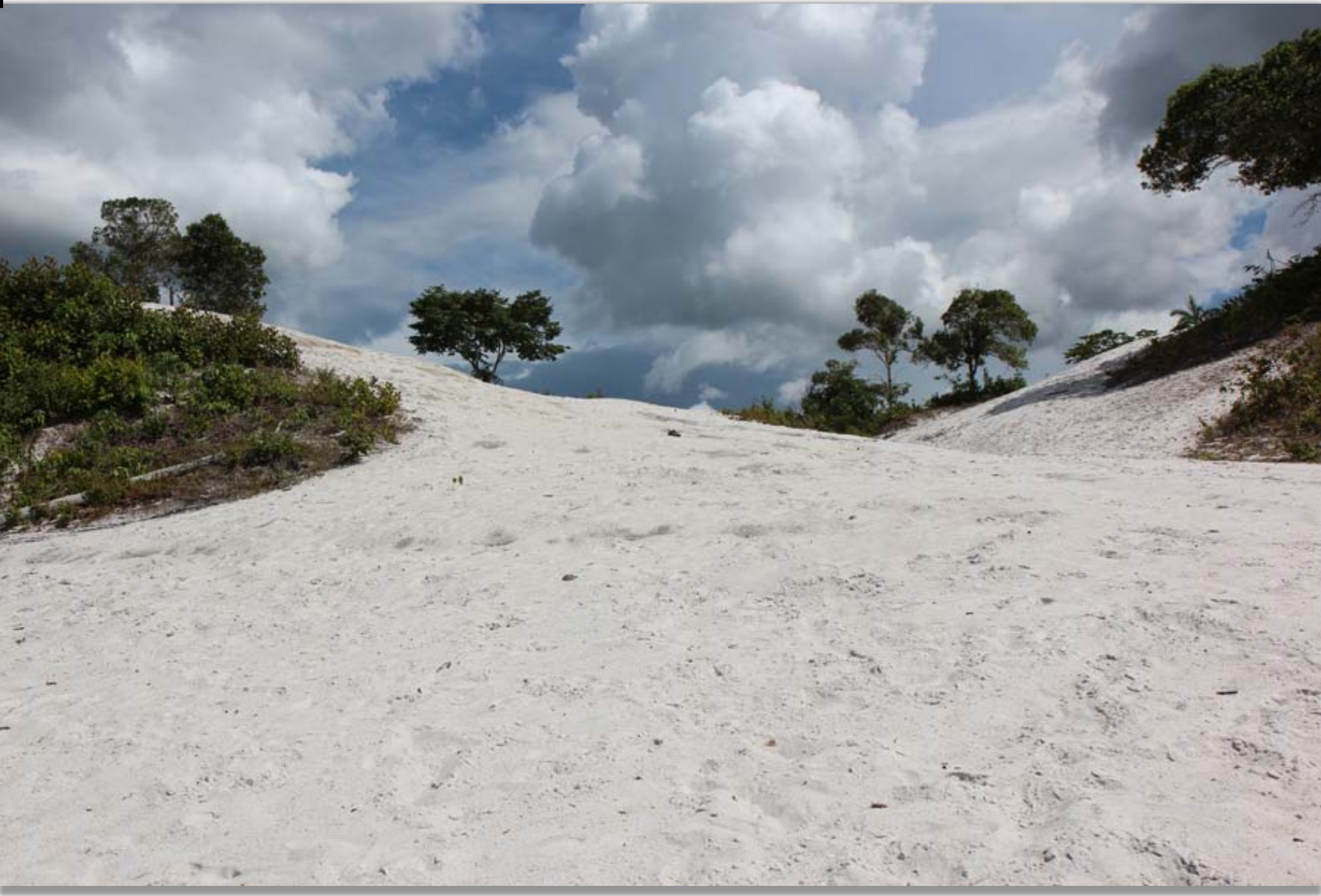




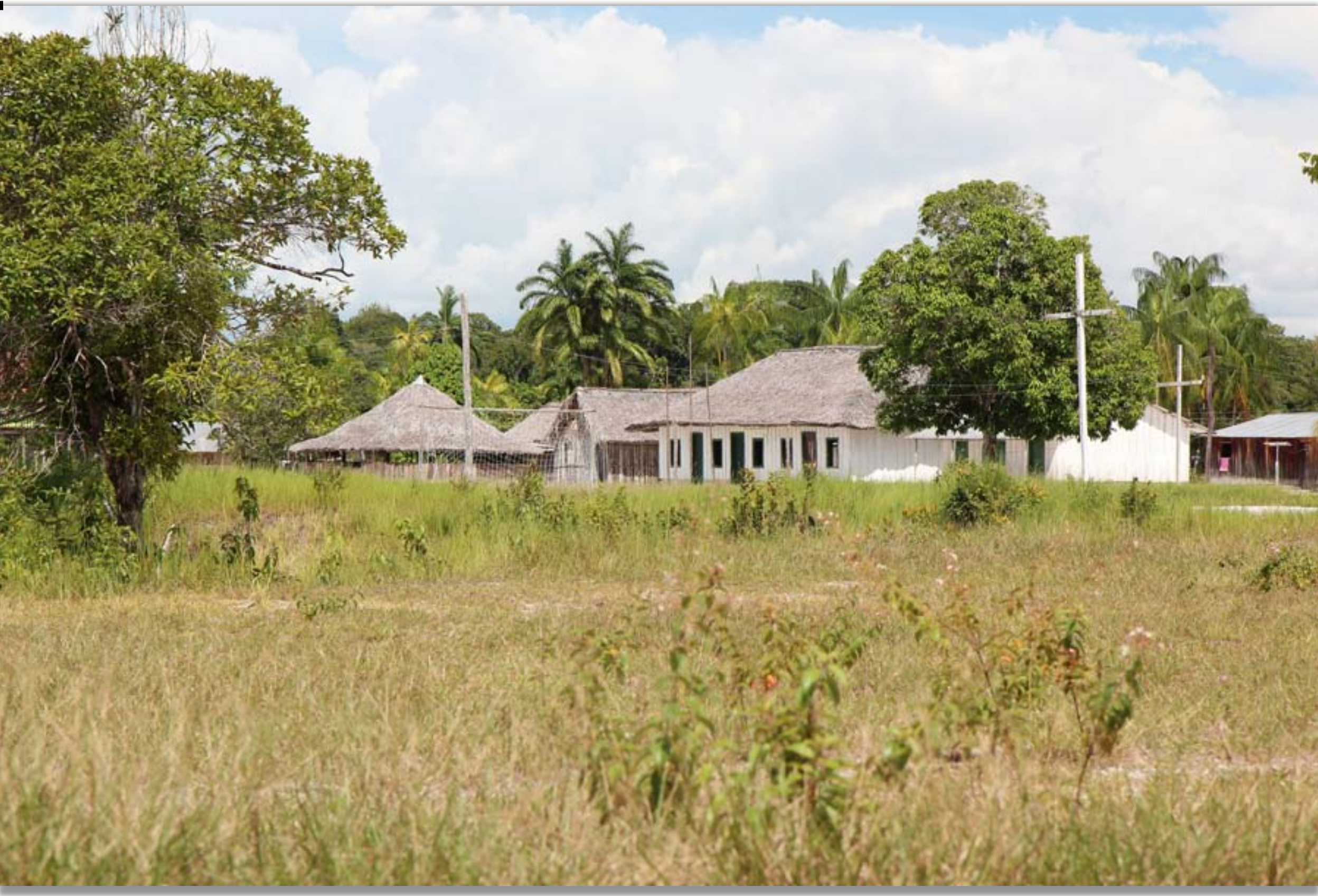

Monte Alegre, Uaupés River. It is in places like this that you can sling your hammock and sleep 


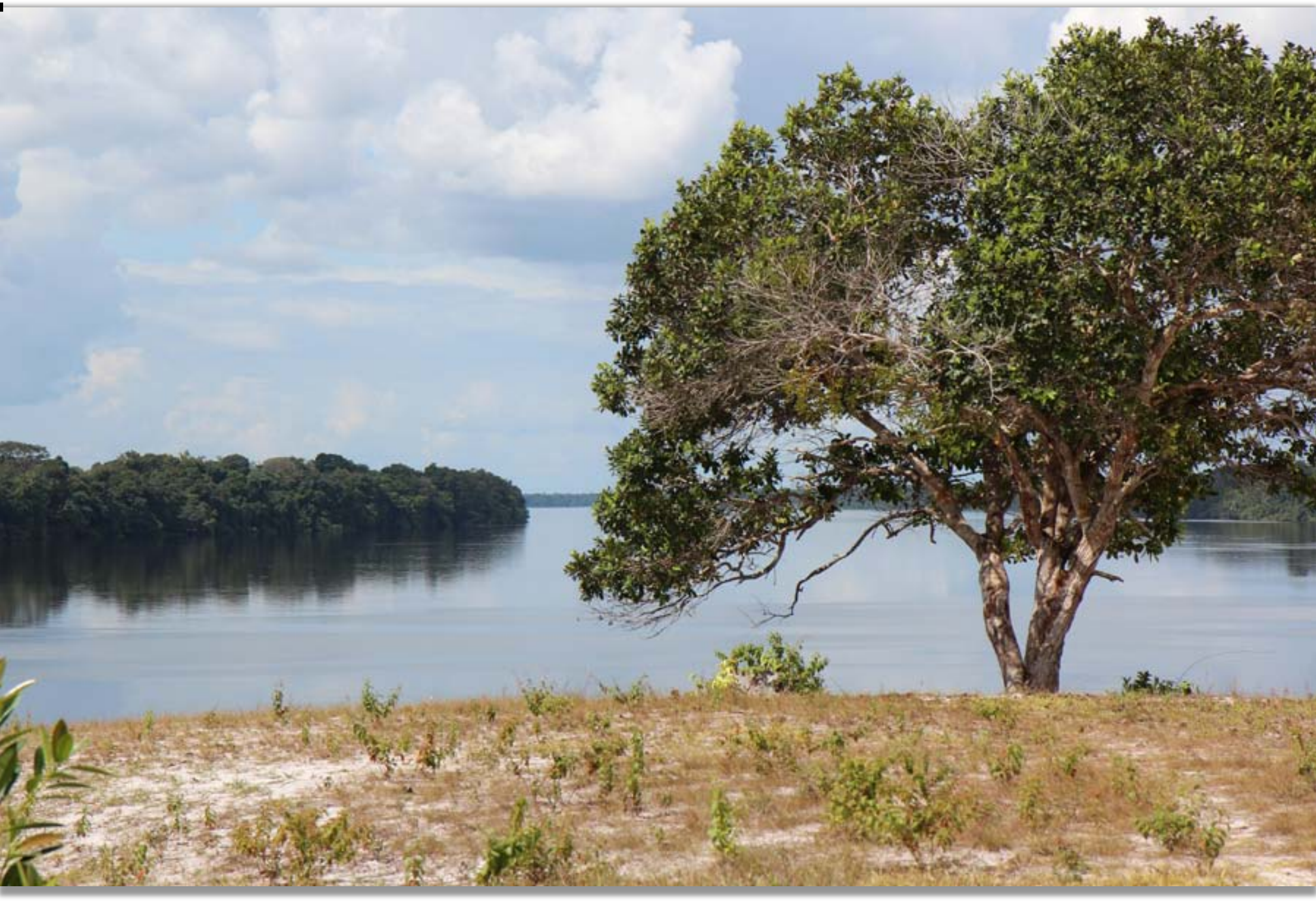




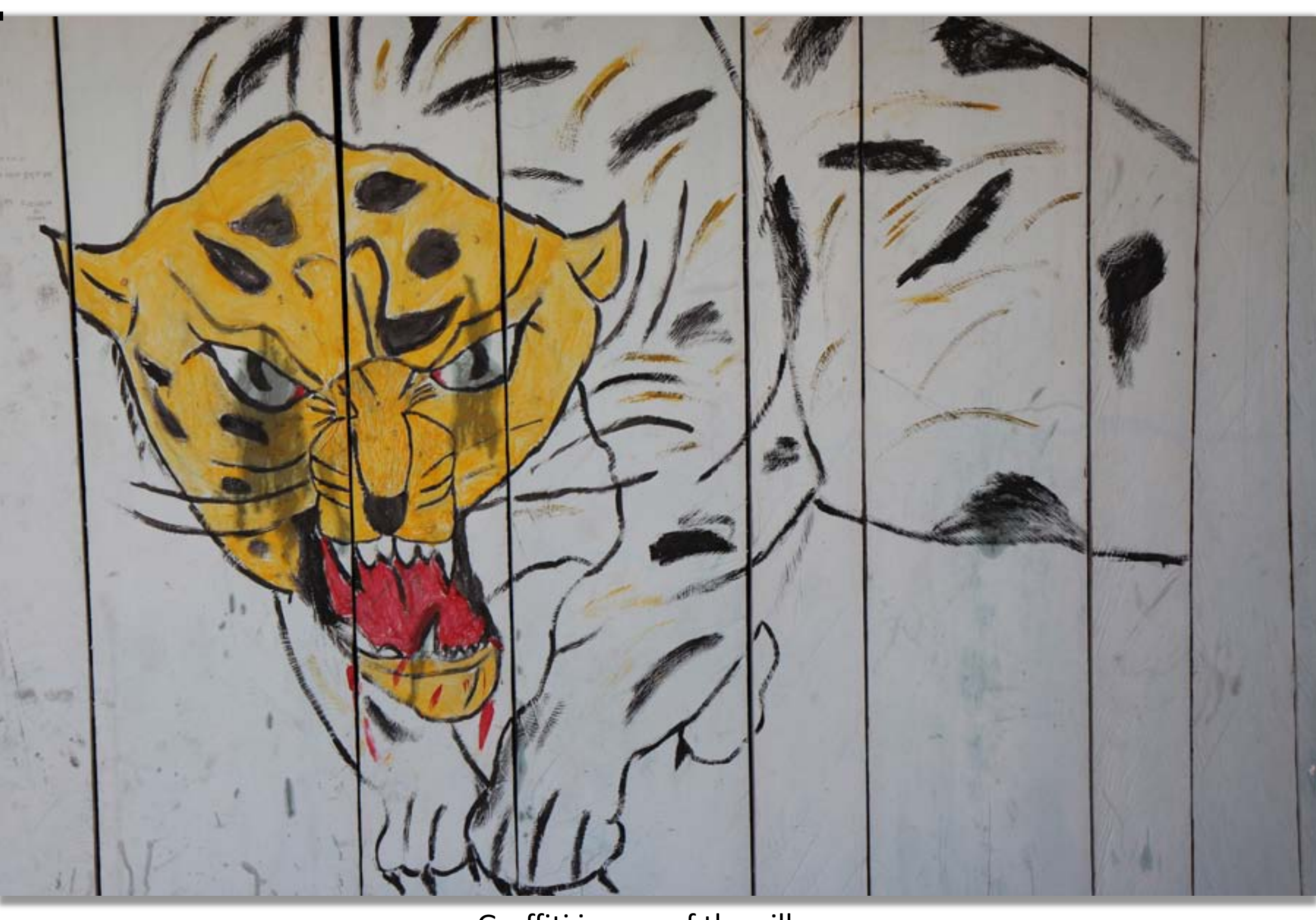

Graffiti in one of the villages 


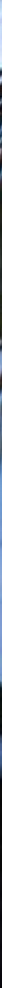




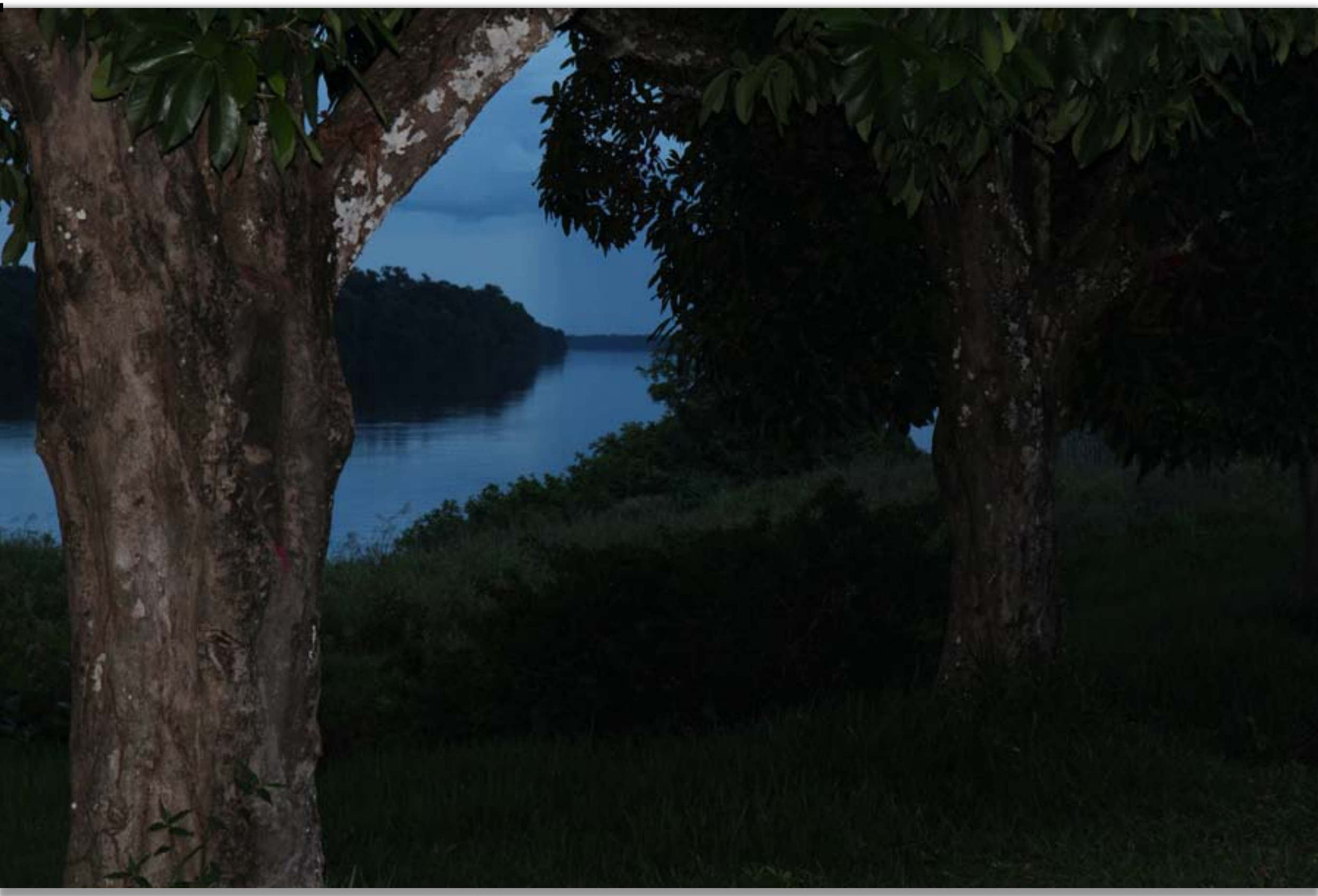

Uaupés River 


\section{Taracuá Igarapé}

The Hup'däh village 


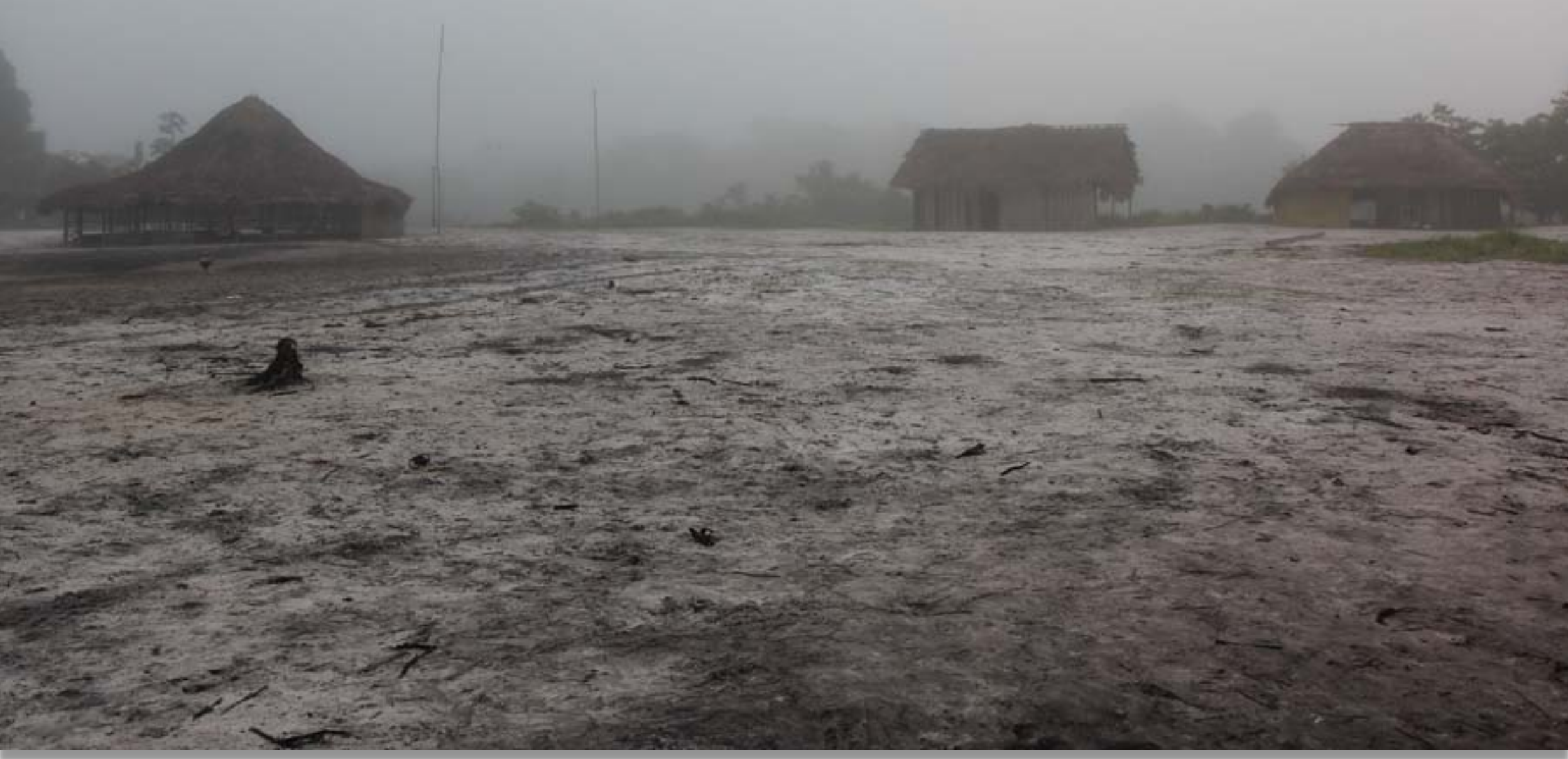

In the mornings a heavy fog covers the village 


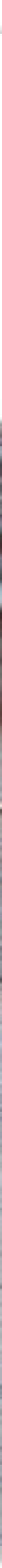




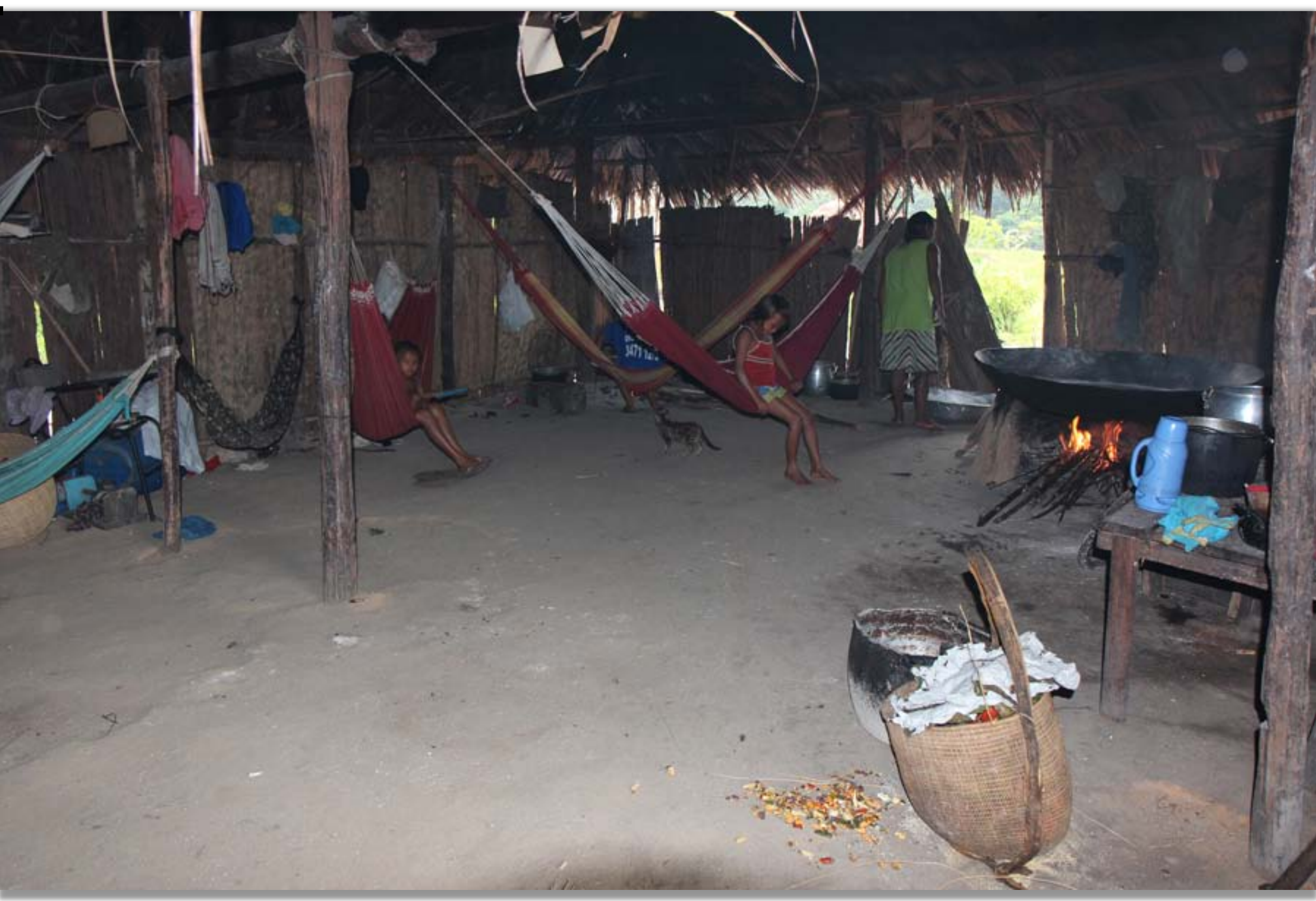




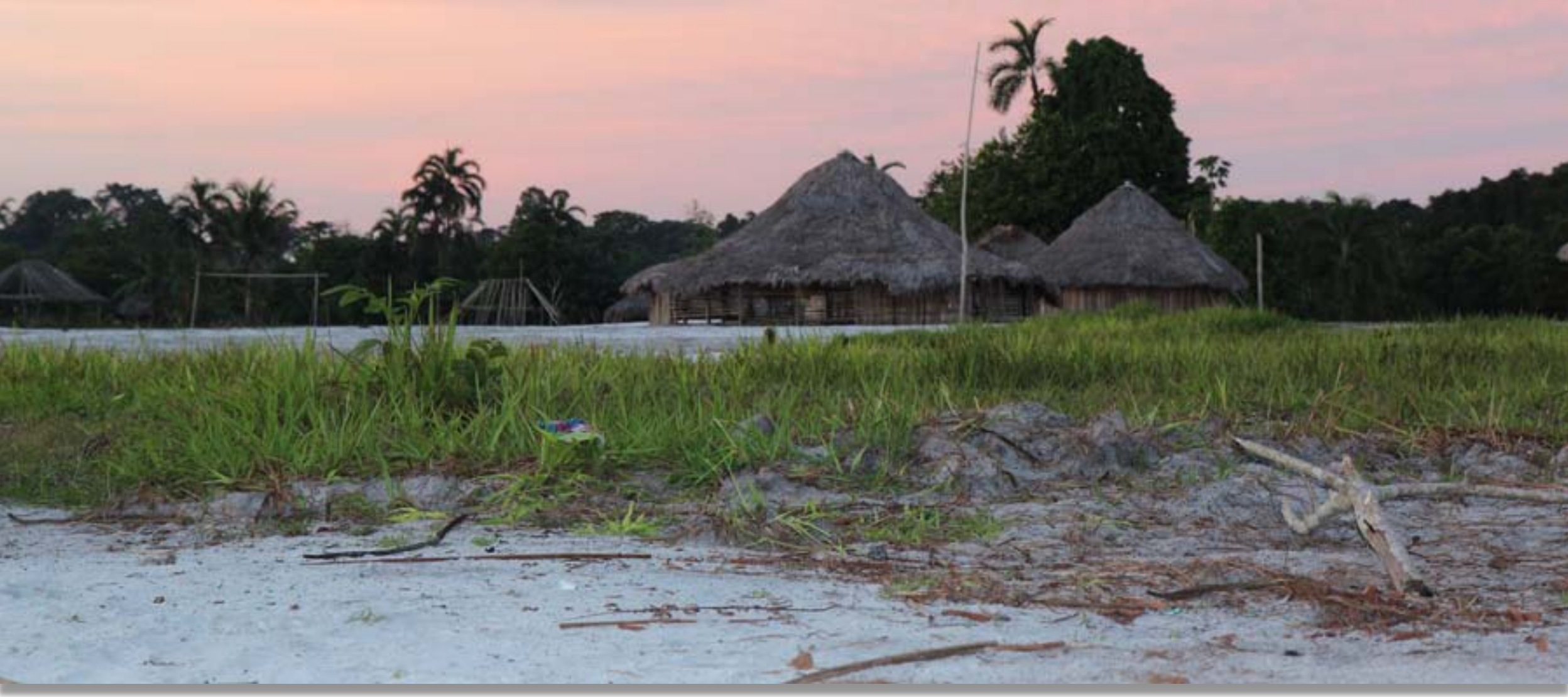




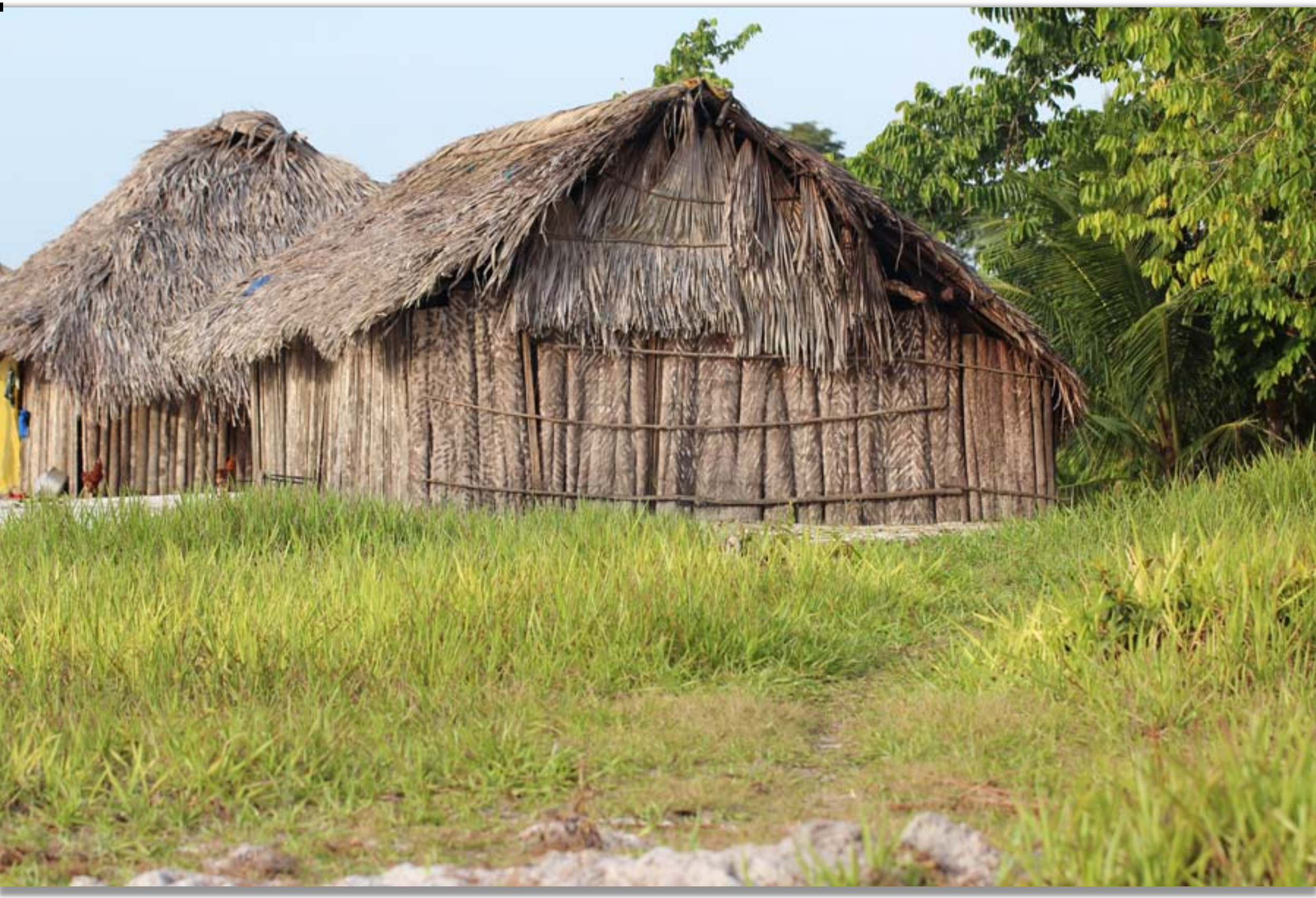




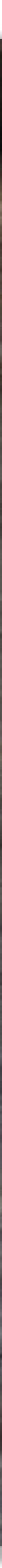

Paxiuba (Iriartea Deltoidea) is a good palm tree for making house walls 


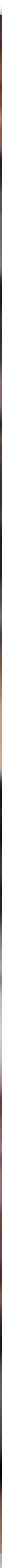

Detail of the roof in a Hup'däh house 

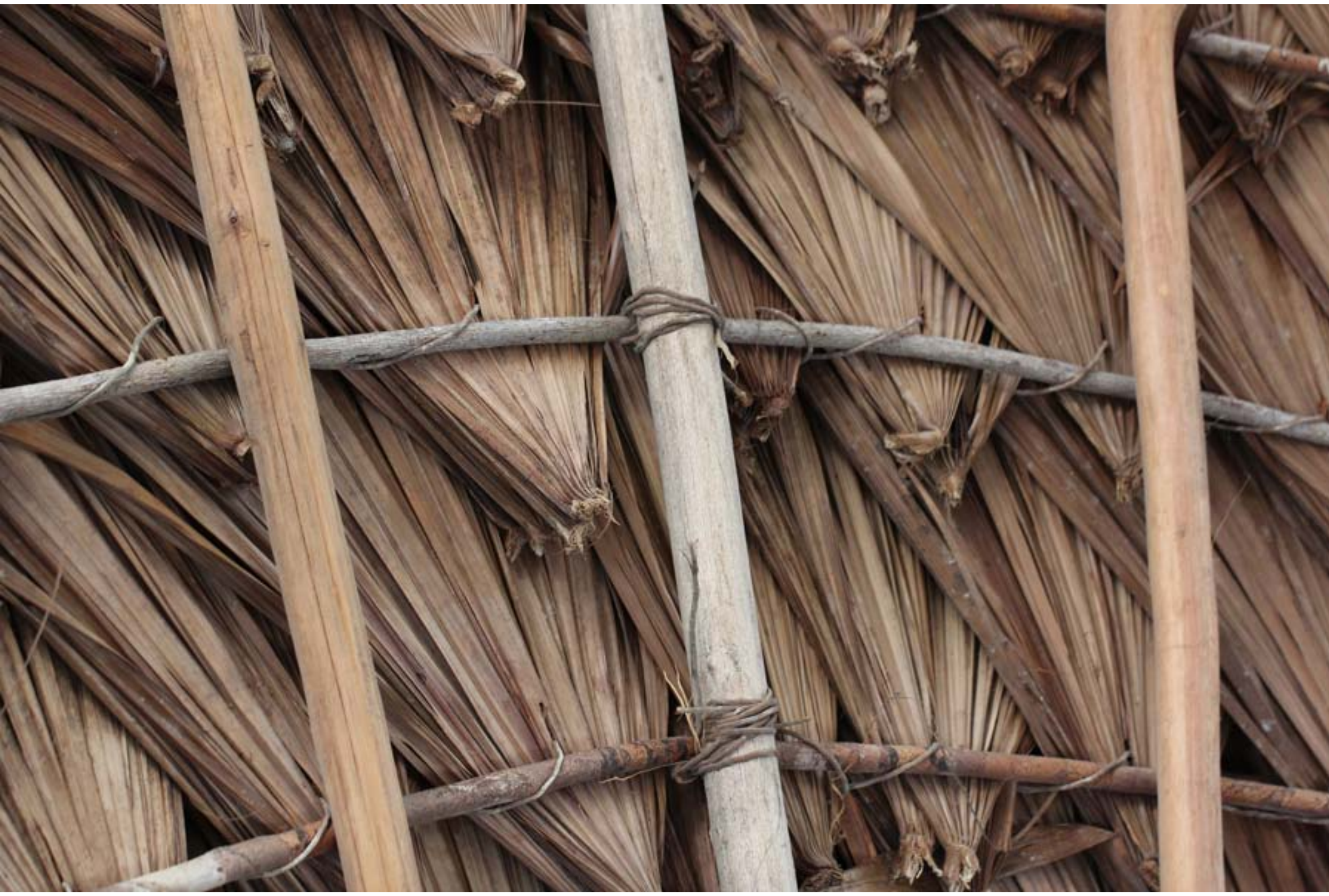

Detail of the covering of the roof, with caranã palm leaves 

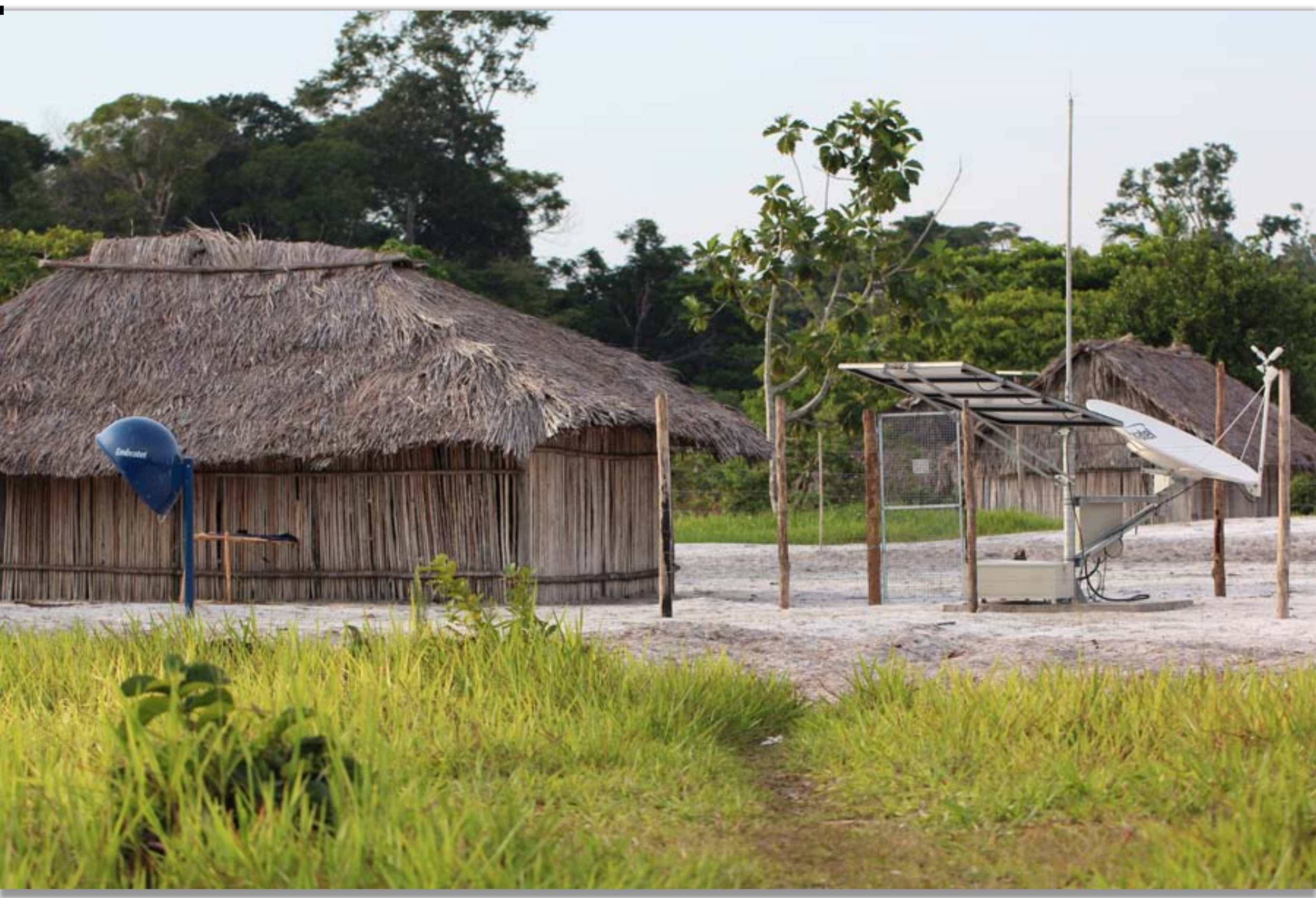

Public telephone in the village 


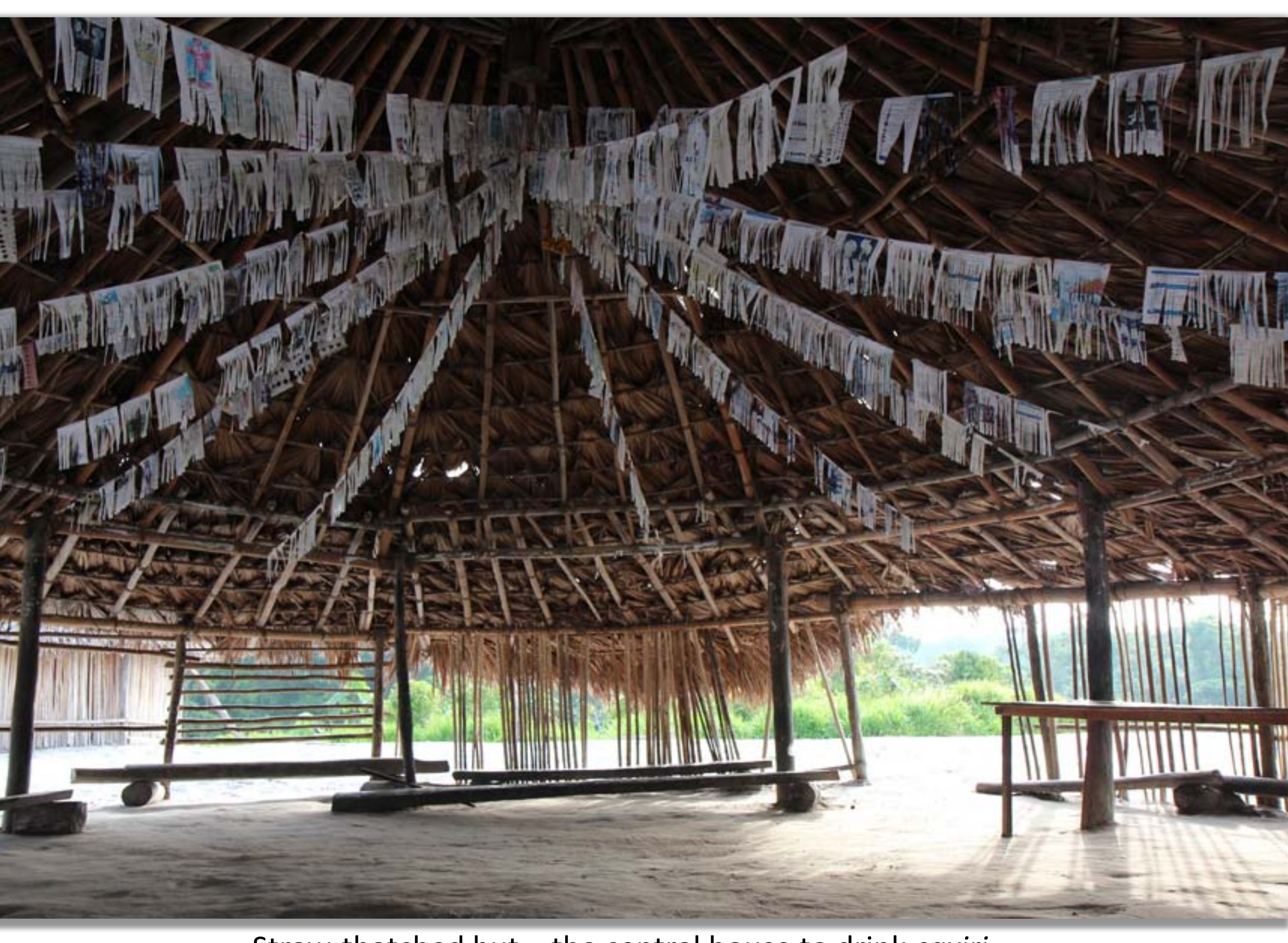

Straw-thatched hut - the central house to drink caxiri 


\section{$\sin (1,4)=4$}

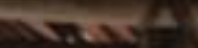

Ijo:

III

(17.

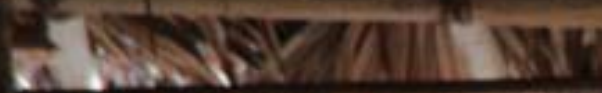

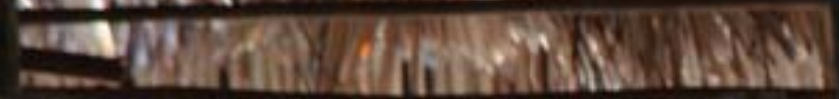
แ⿴囗十

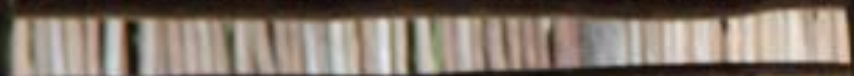

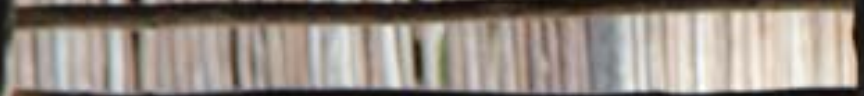

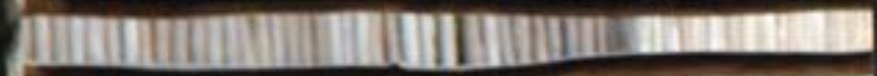
Y)

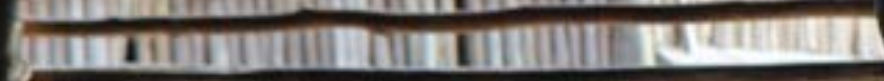

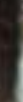

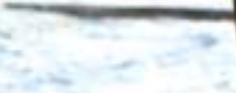

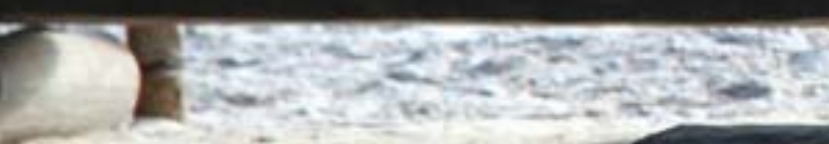

\section{II}

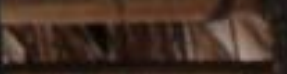

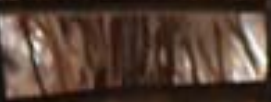
EIMITHEY

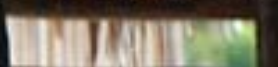

पIIIIII)

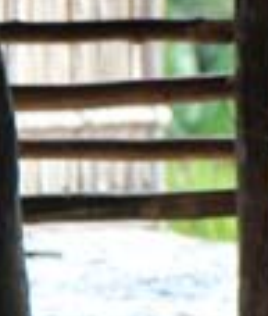

DEI

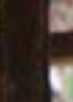

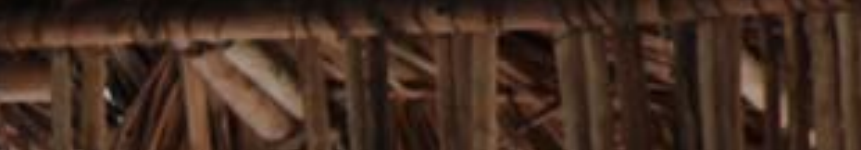

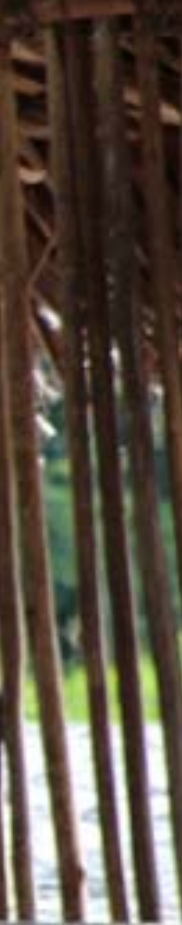

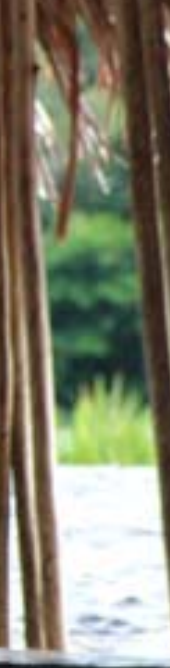
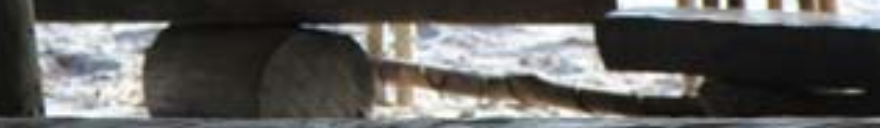
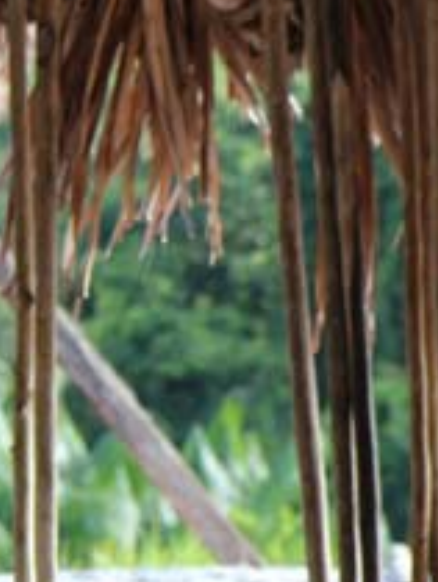

.

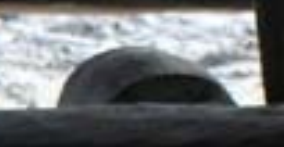
wisin: $=00$ 


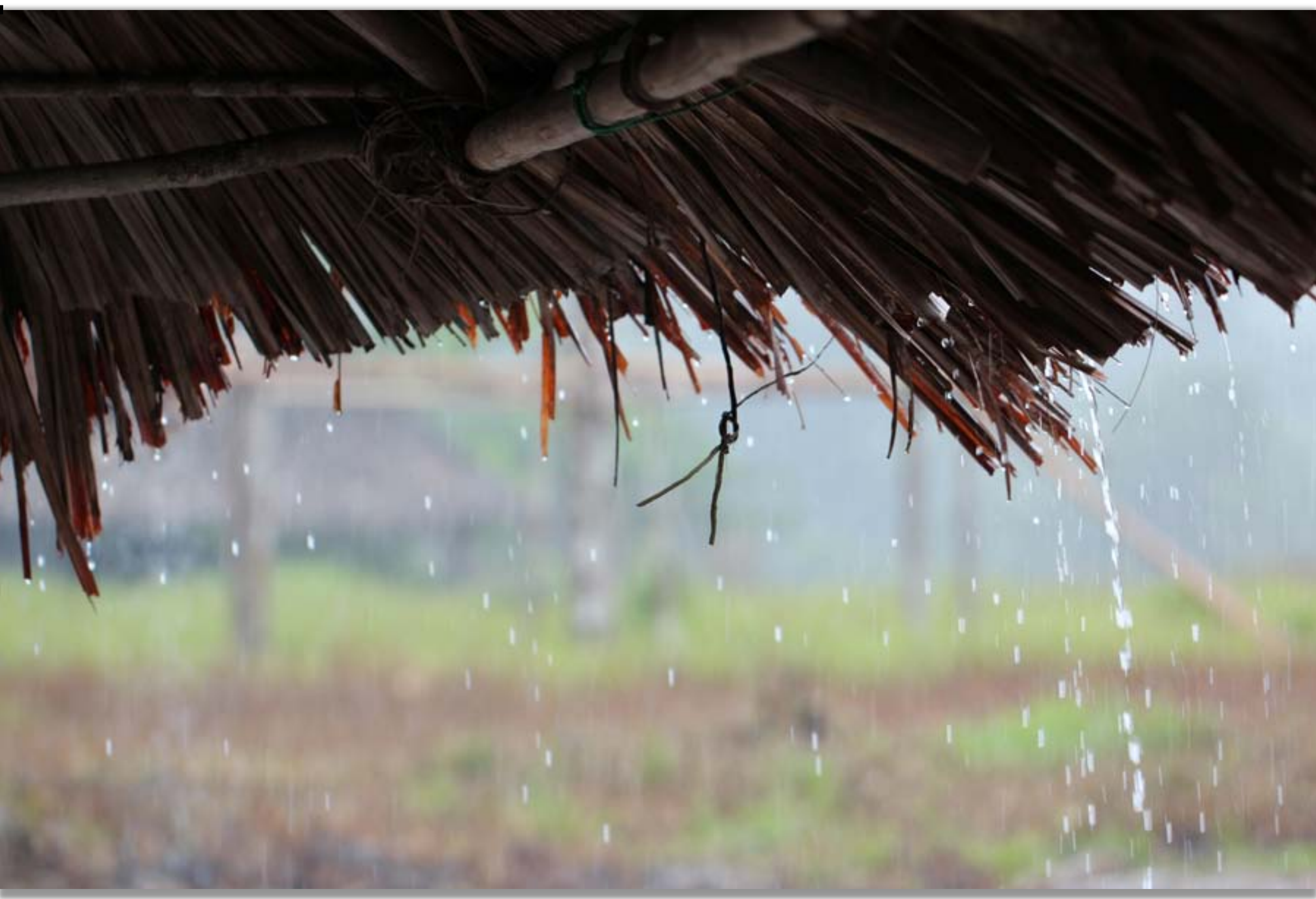




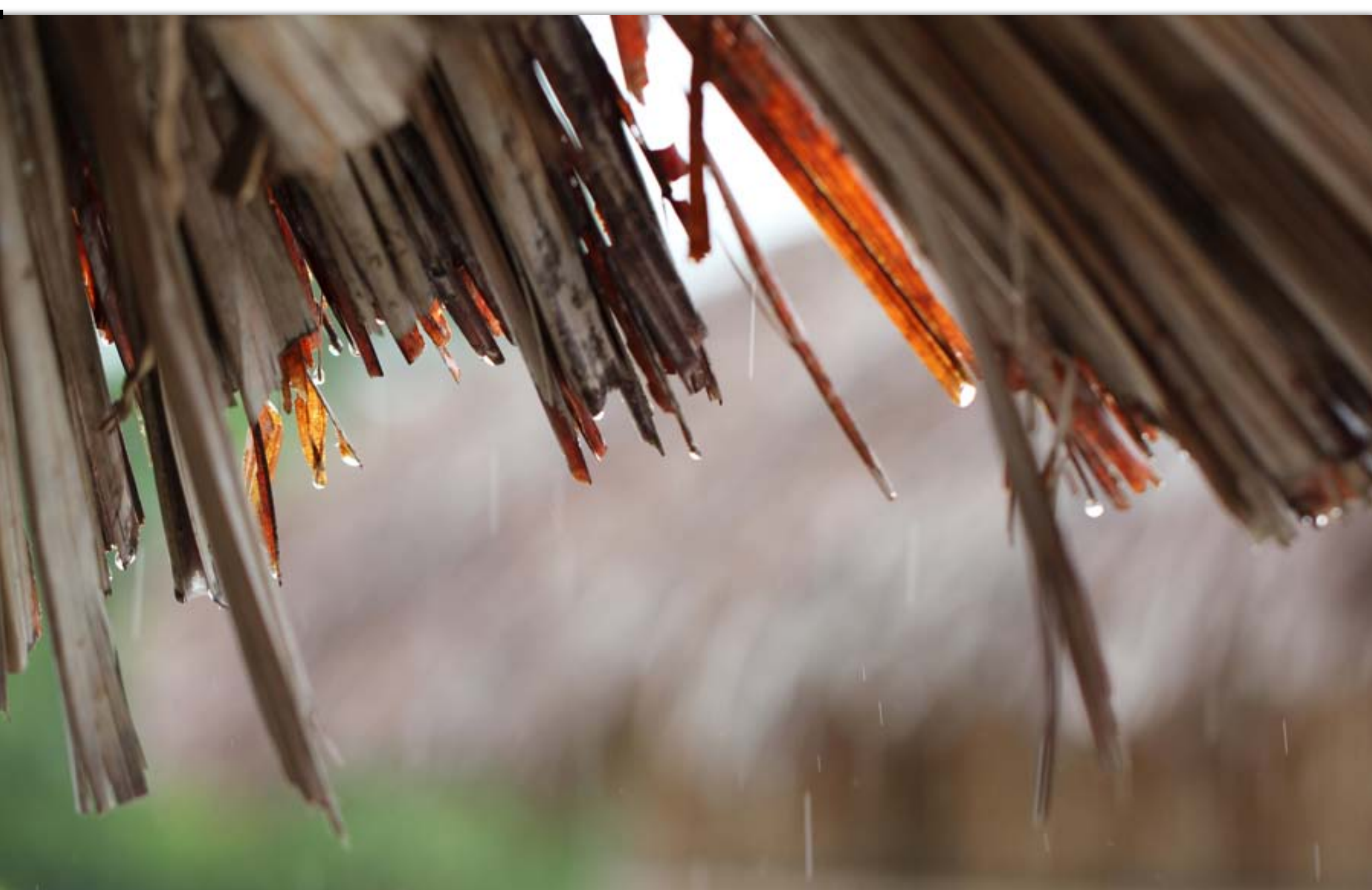




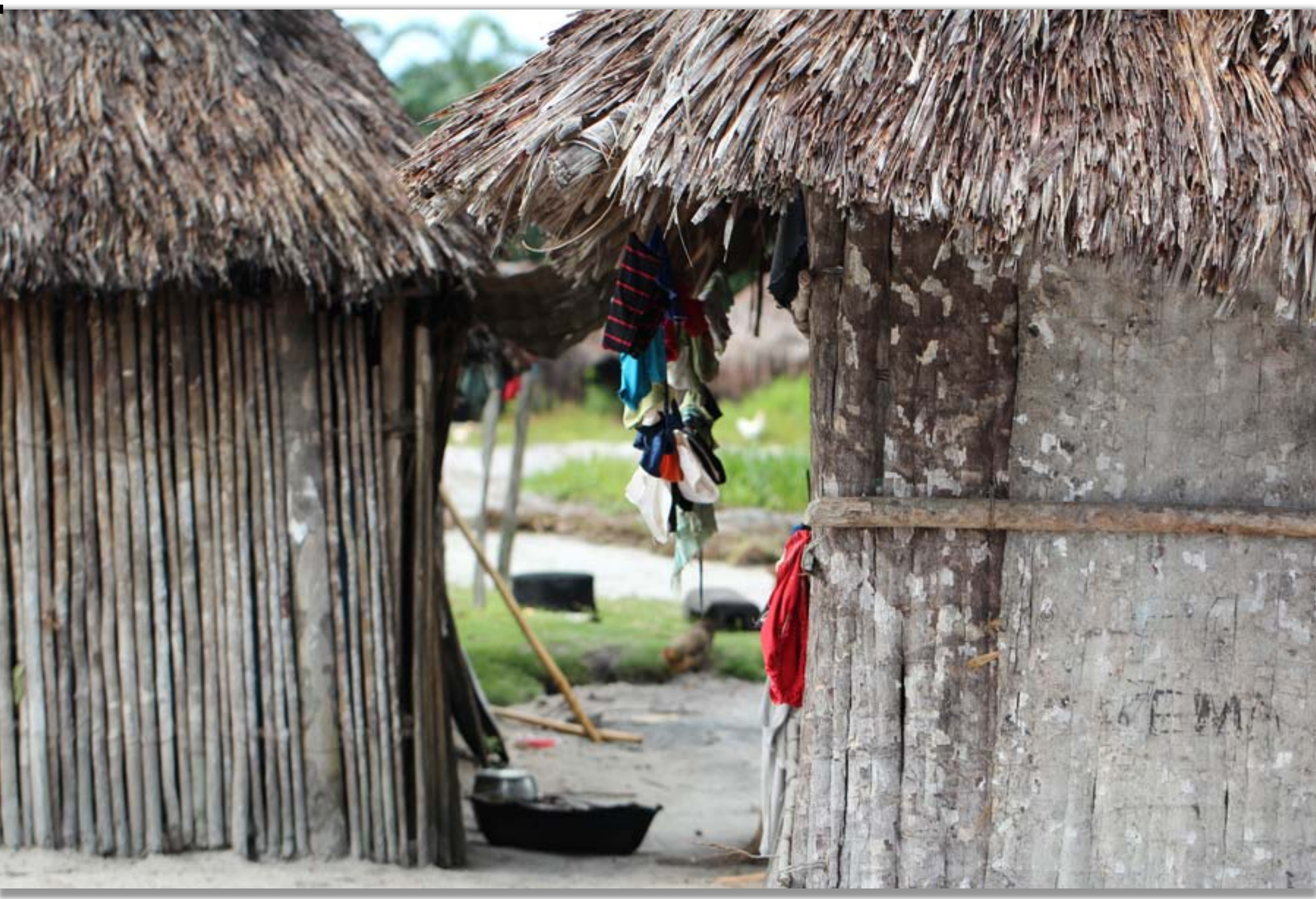

There are different solutions for constructing the house walls 


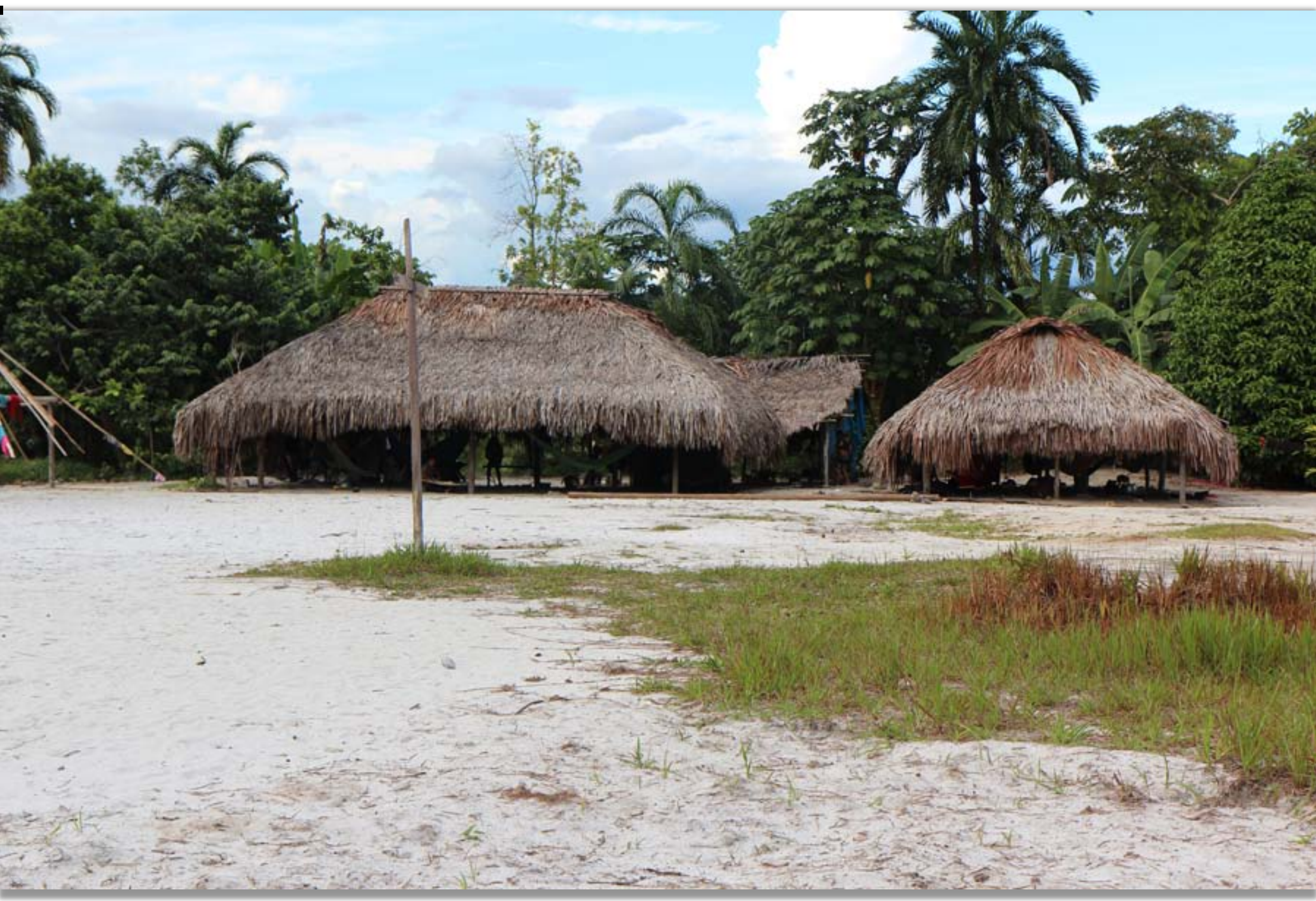

Some houses have no walls 


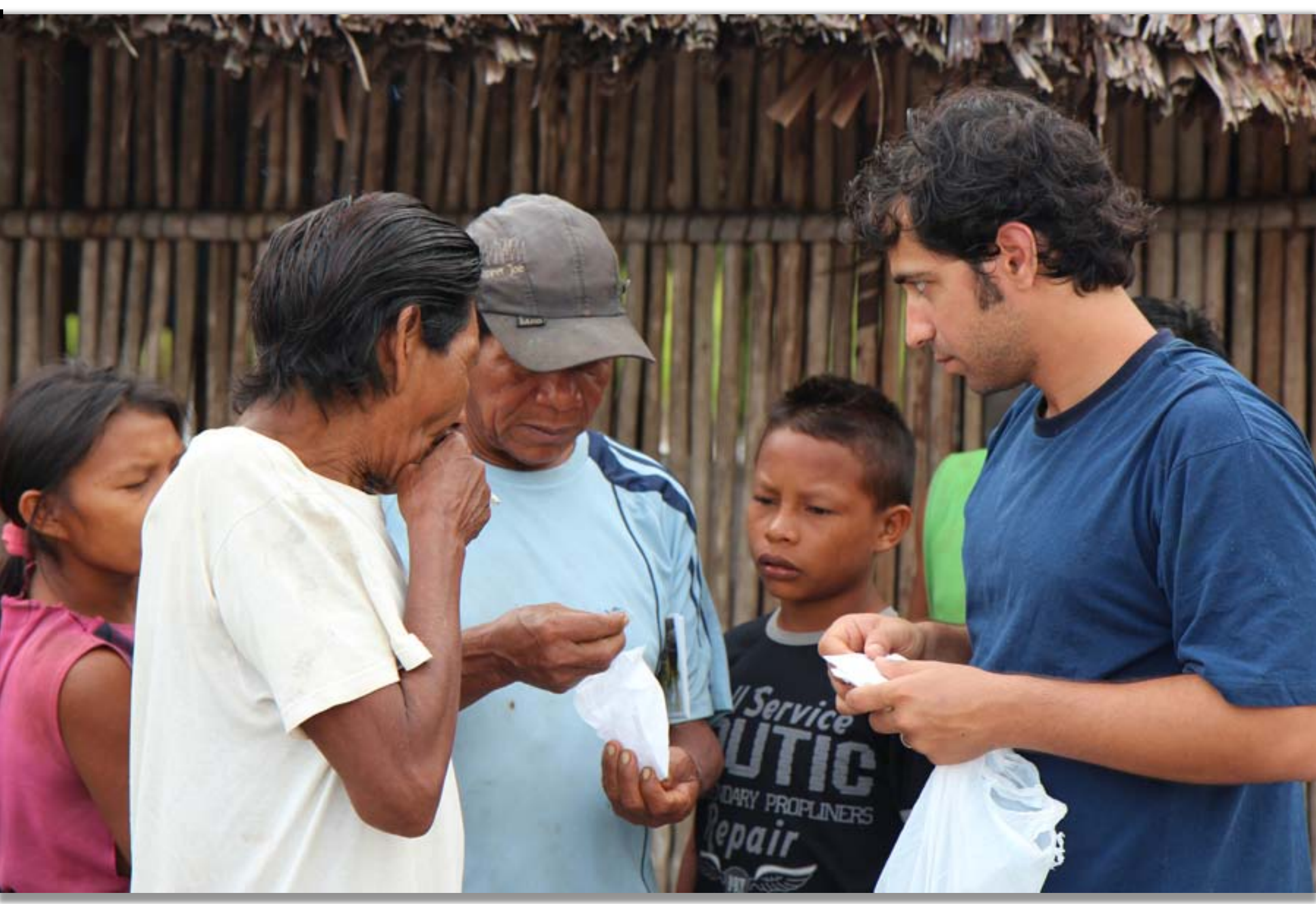

The anthropologist Danilo Paiva Ramos exchanges fish hooks for fish 


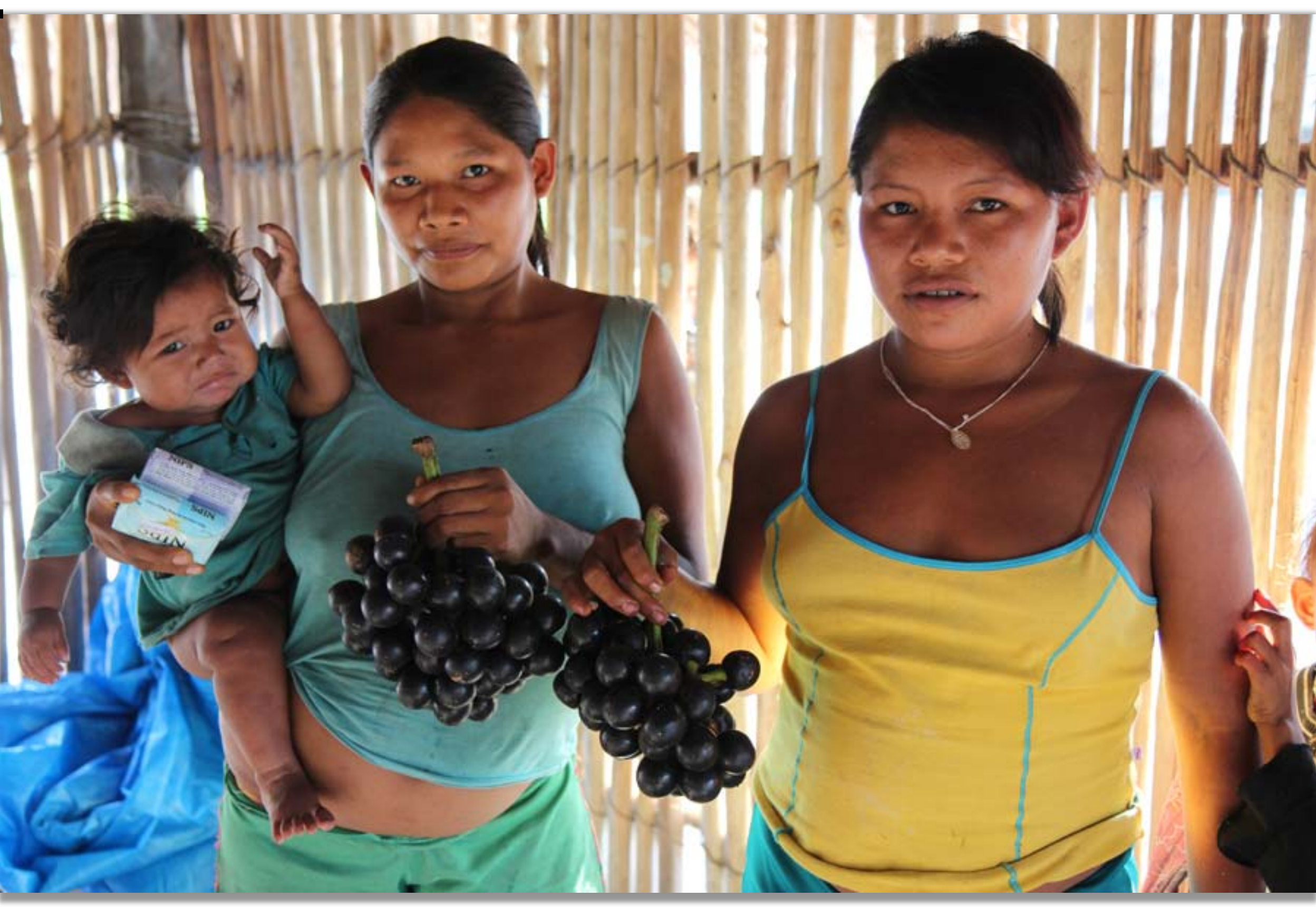

We exchanged soap for cucura, a fruit from the Amazon forest 


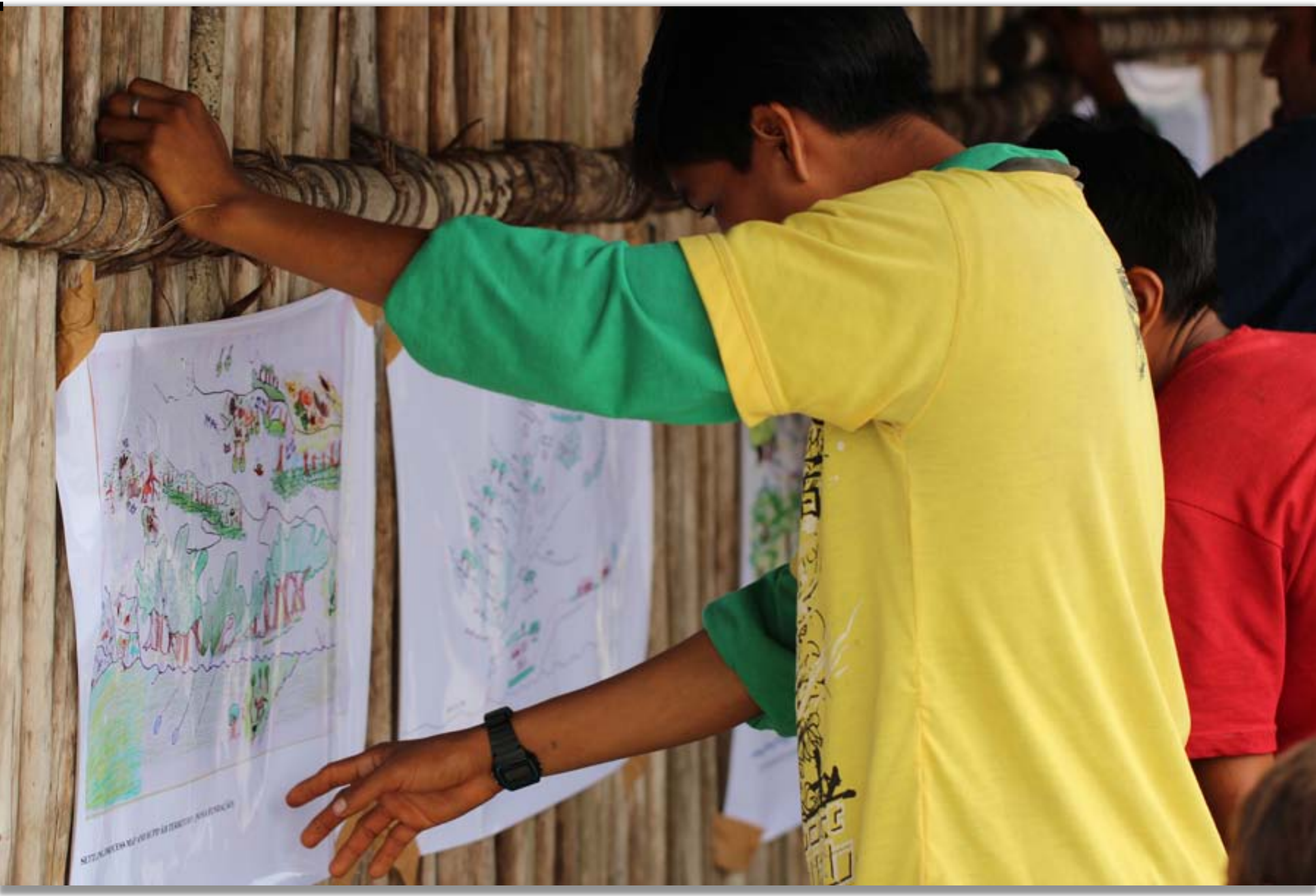

Village maps, made by the Hup'däh, are hung on the wall 


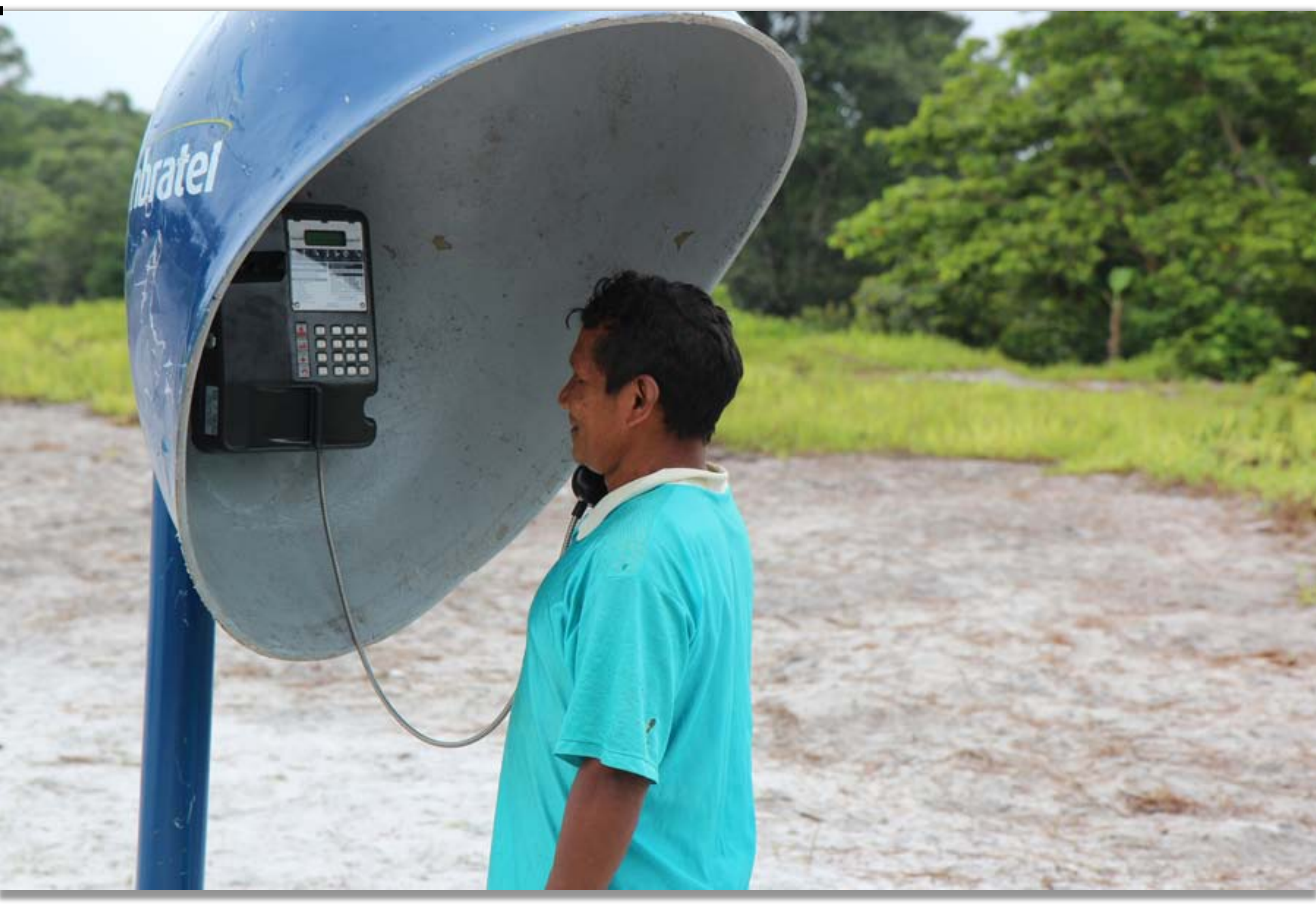

Mandu inaugurates the telephone 


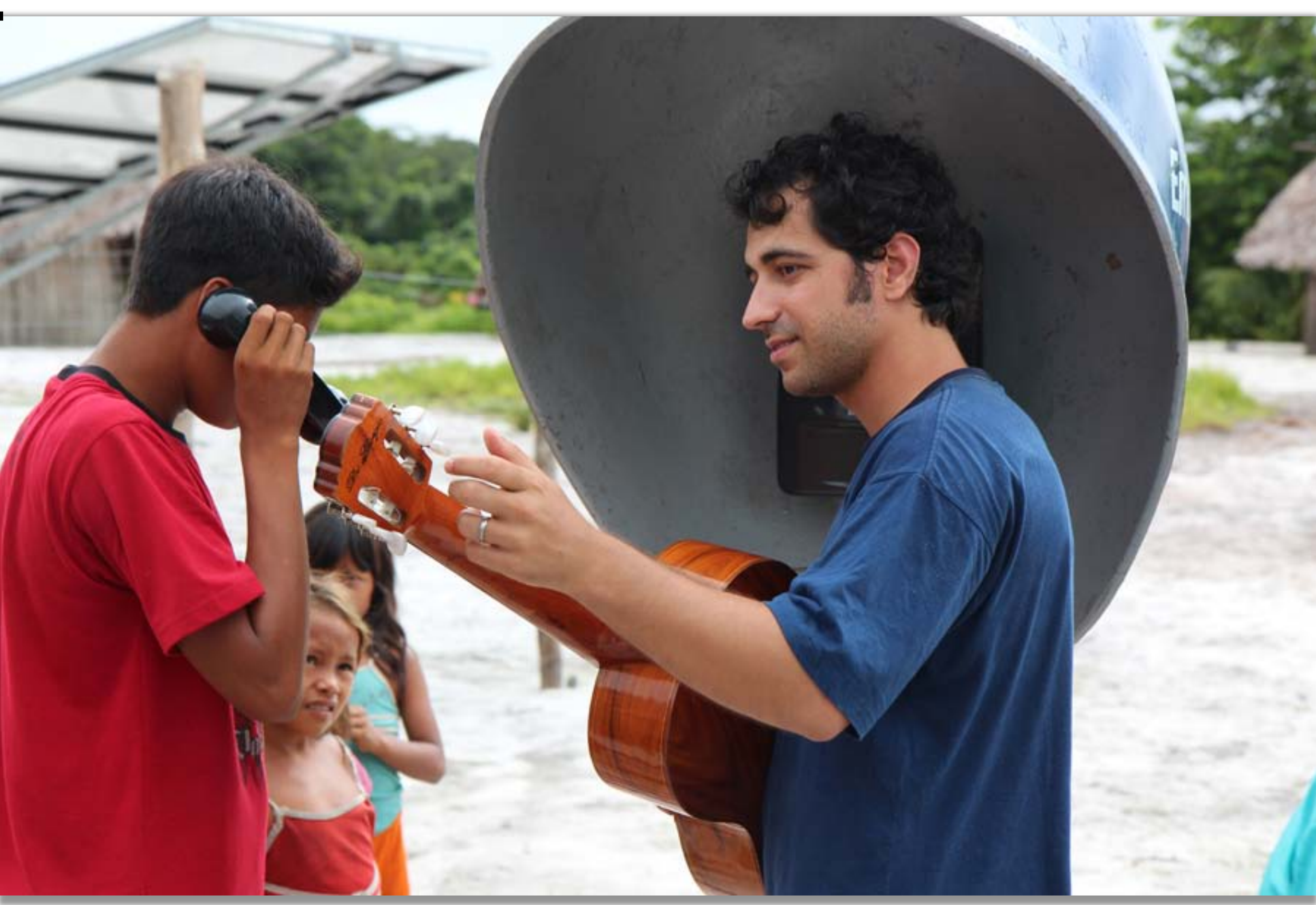

Tuning the guitar by the note la, emitted by the the telephone's dial tone 


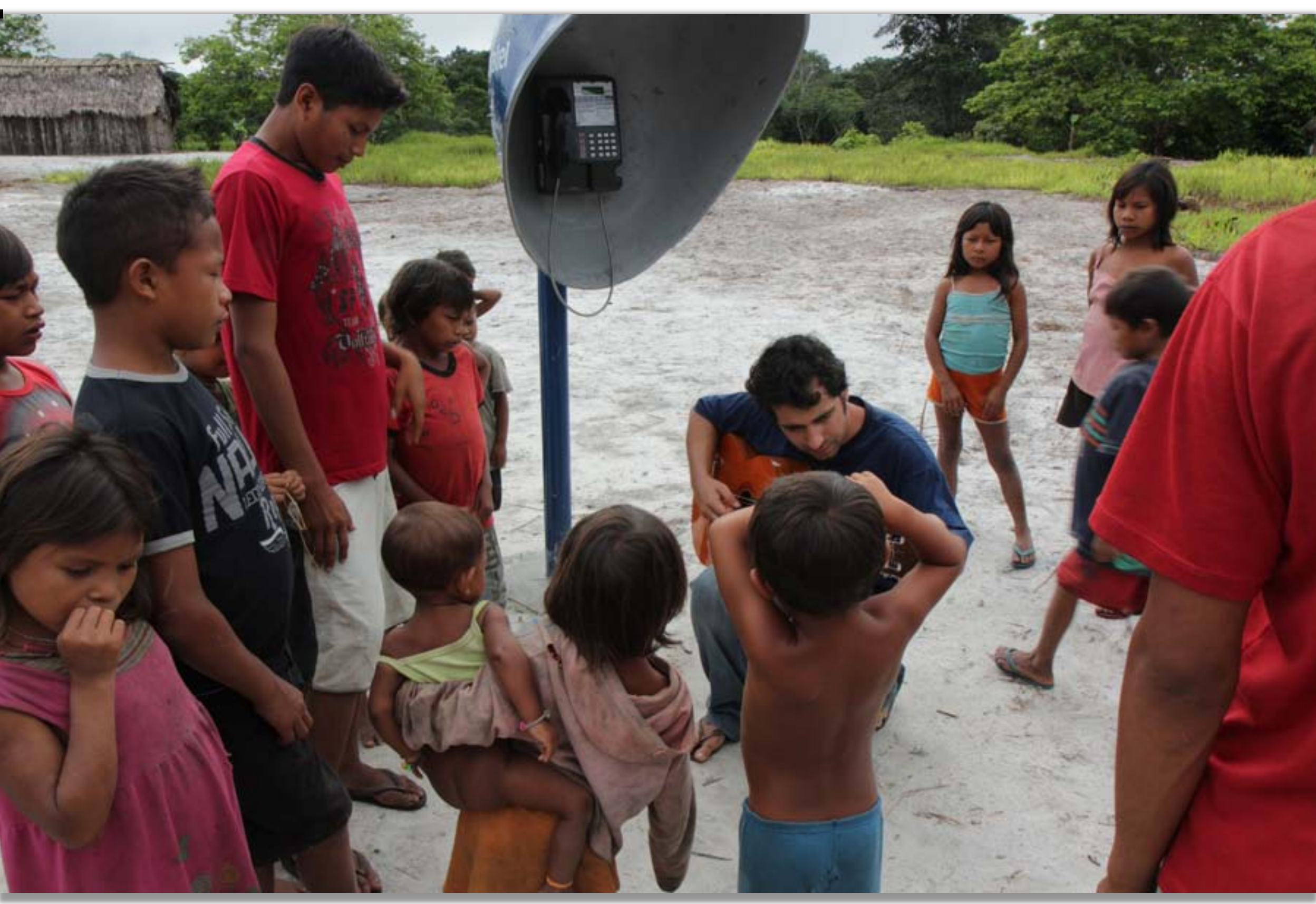




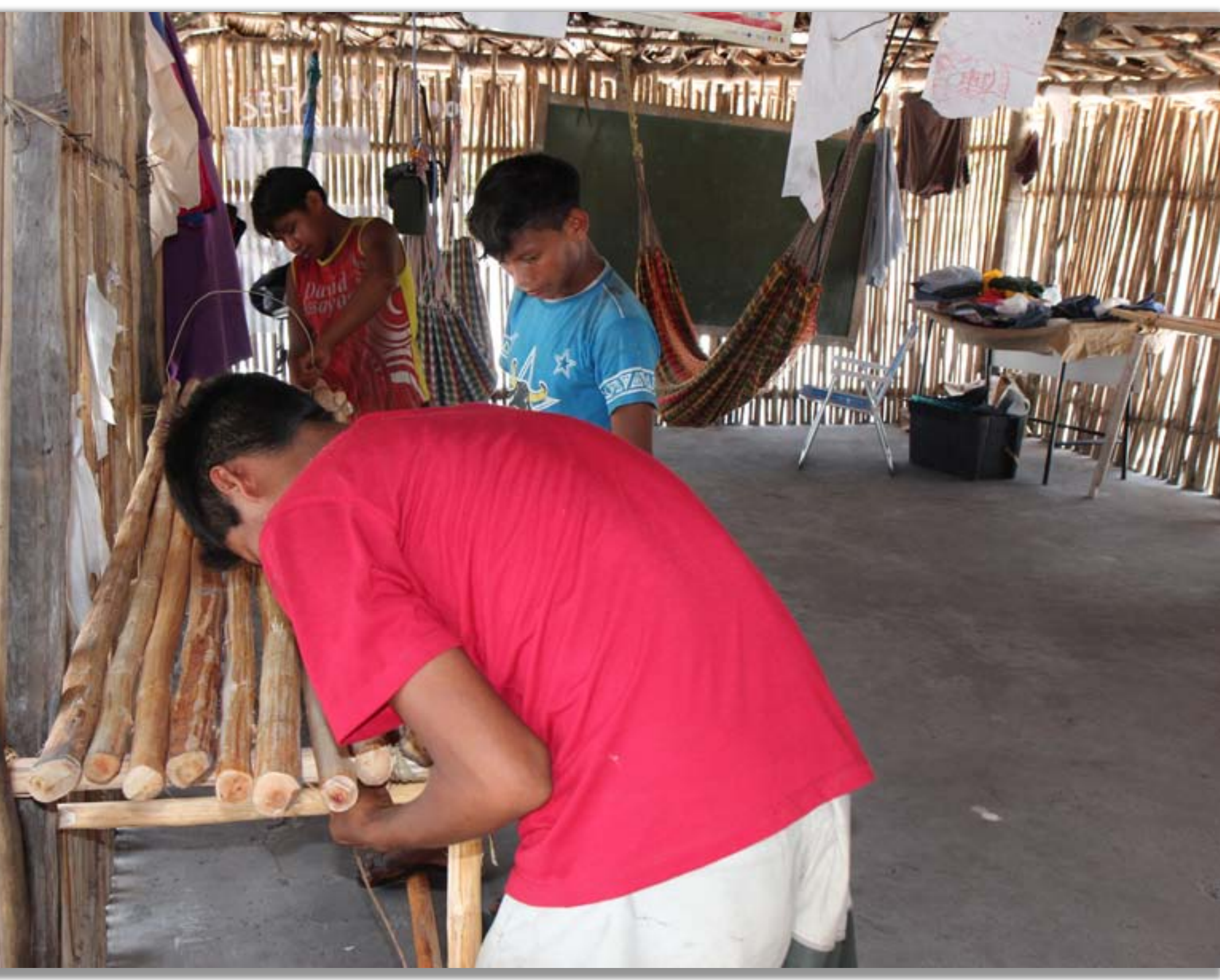

The boys quickly made us a shelf on which to keep our things 


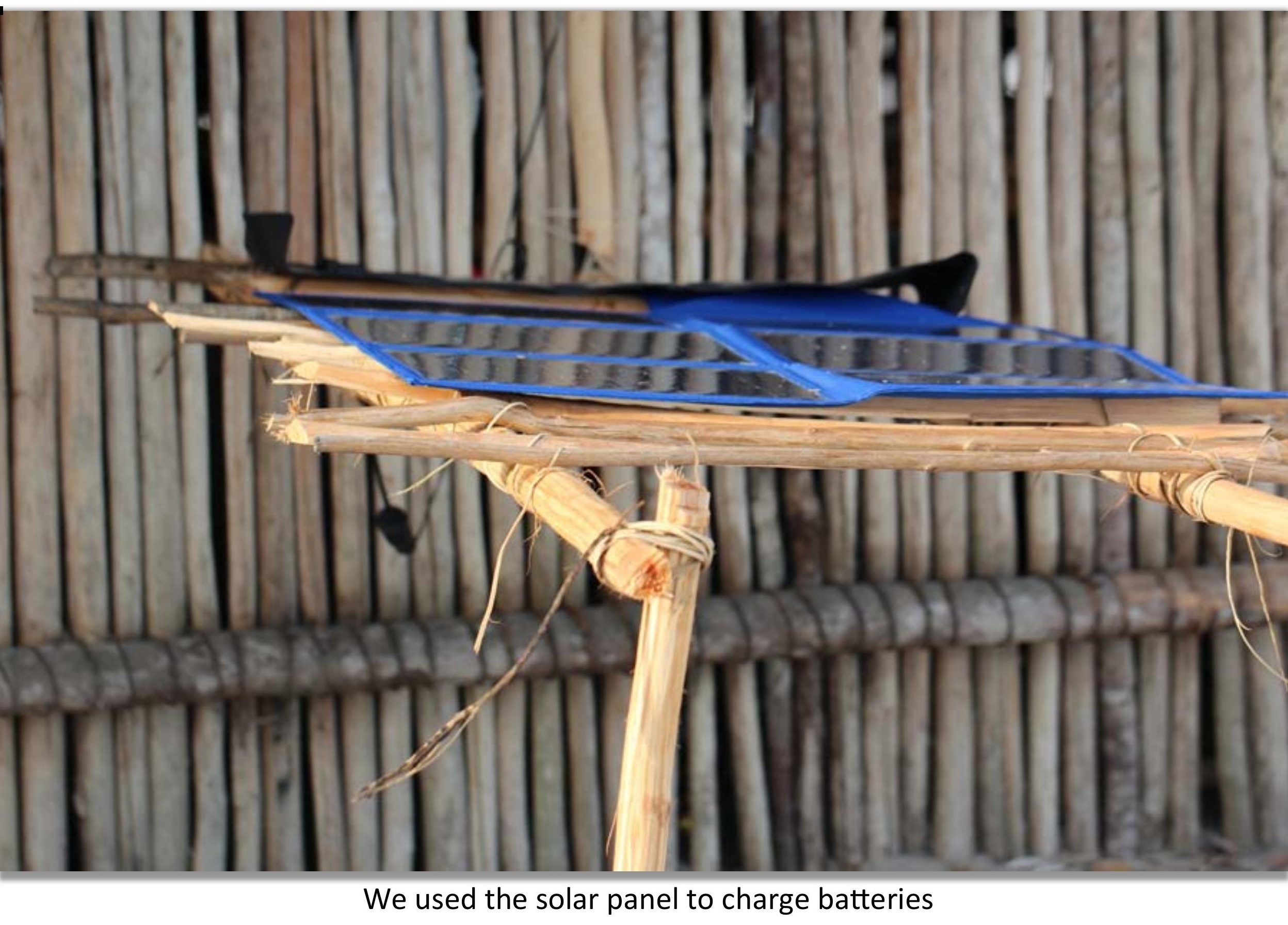






Danilo and Angelino reviewing some myths 


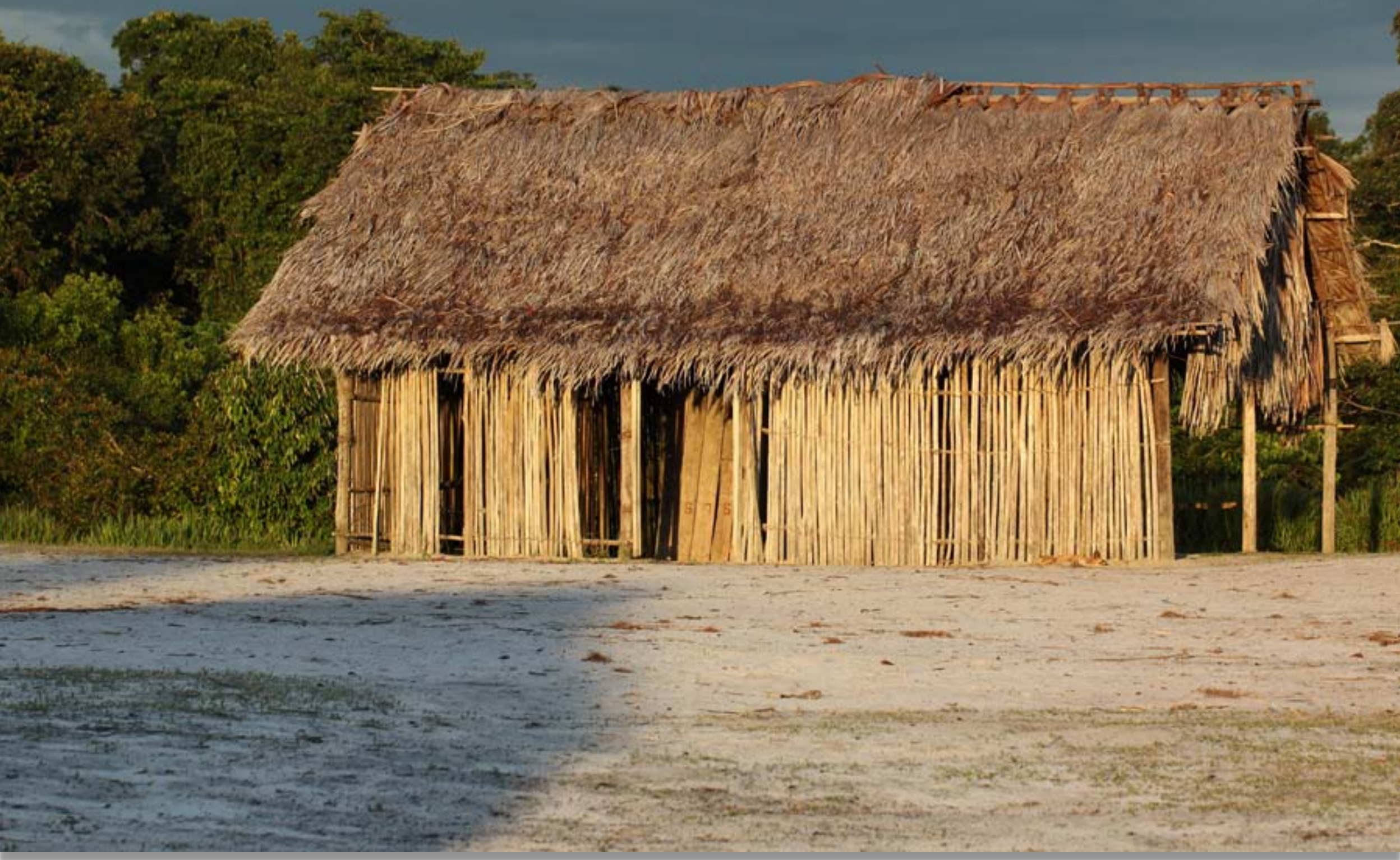

House for the radio in the village 


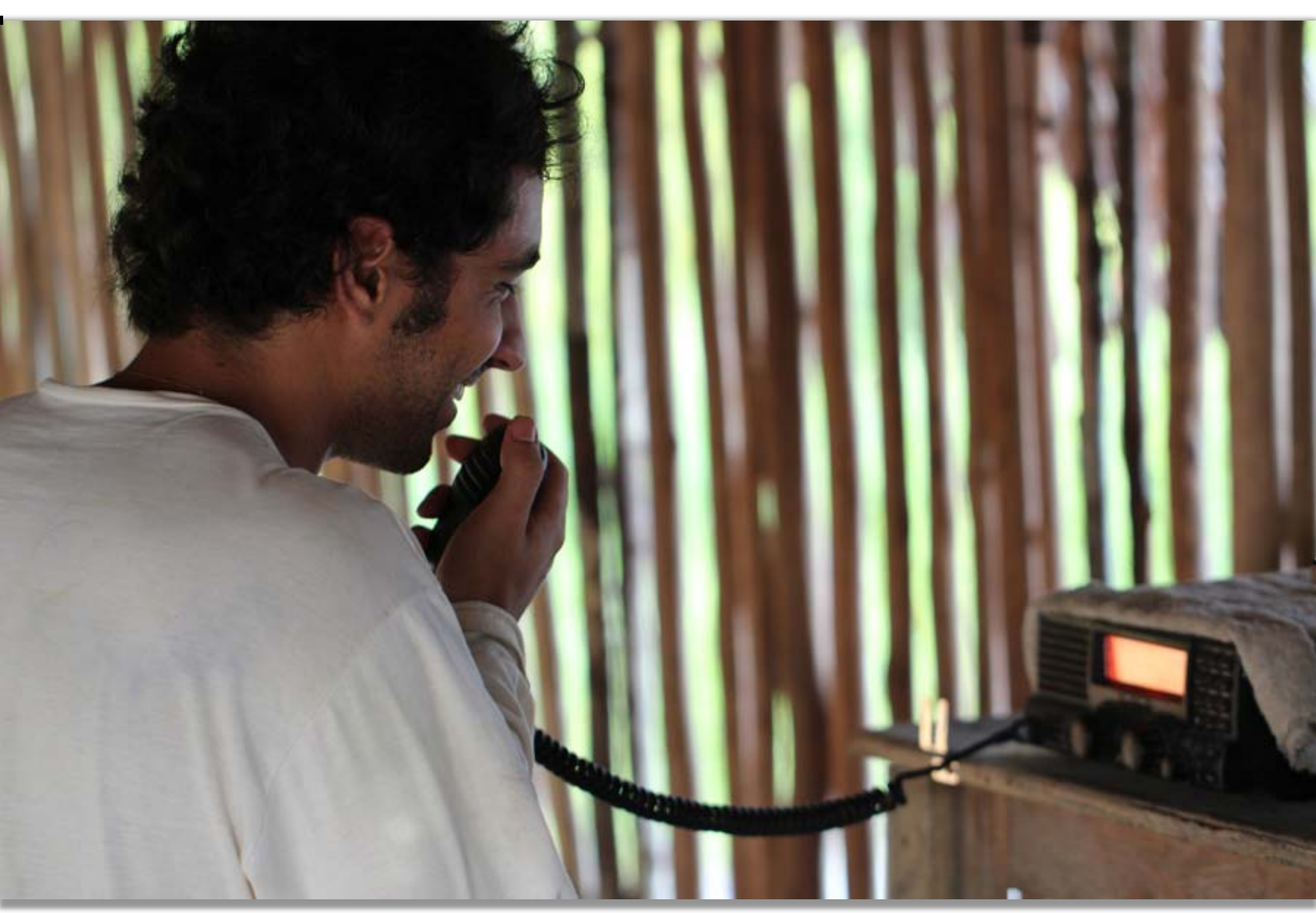




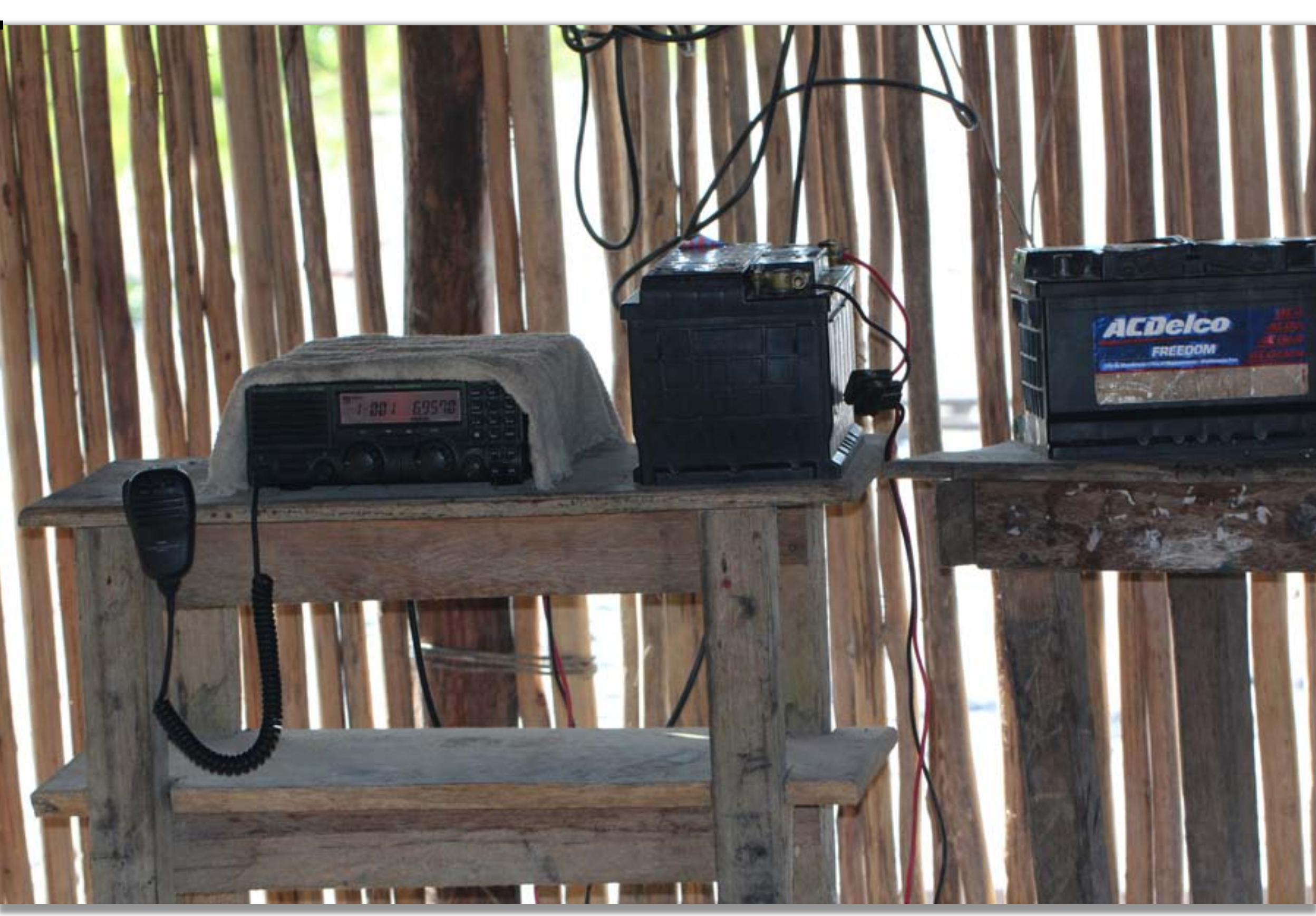




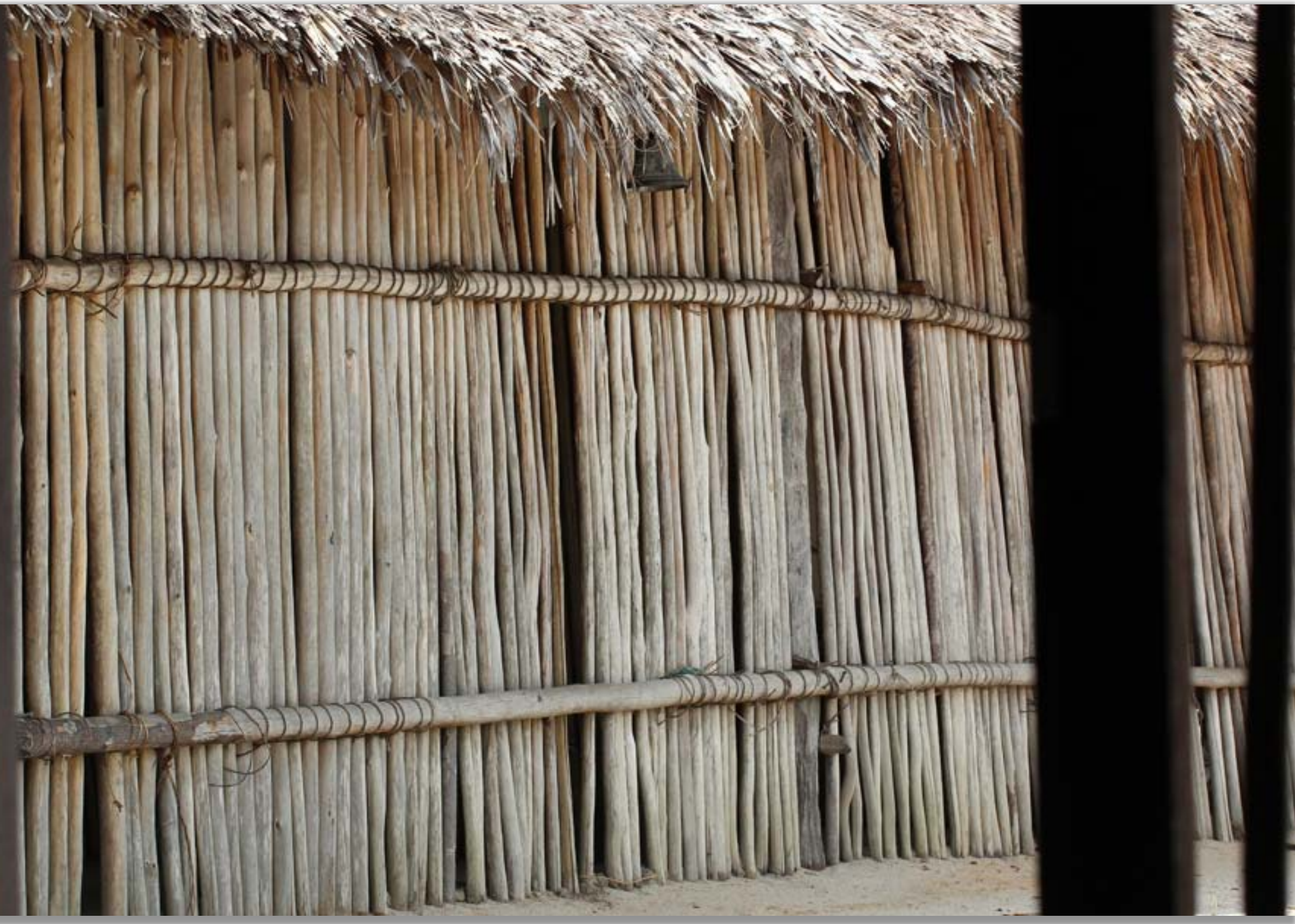

When the bell rings, it is school time for the children 


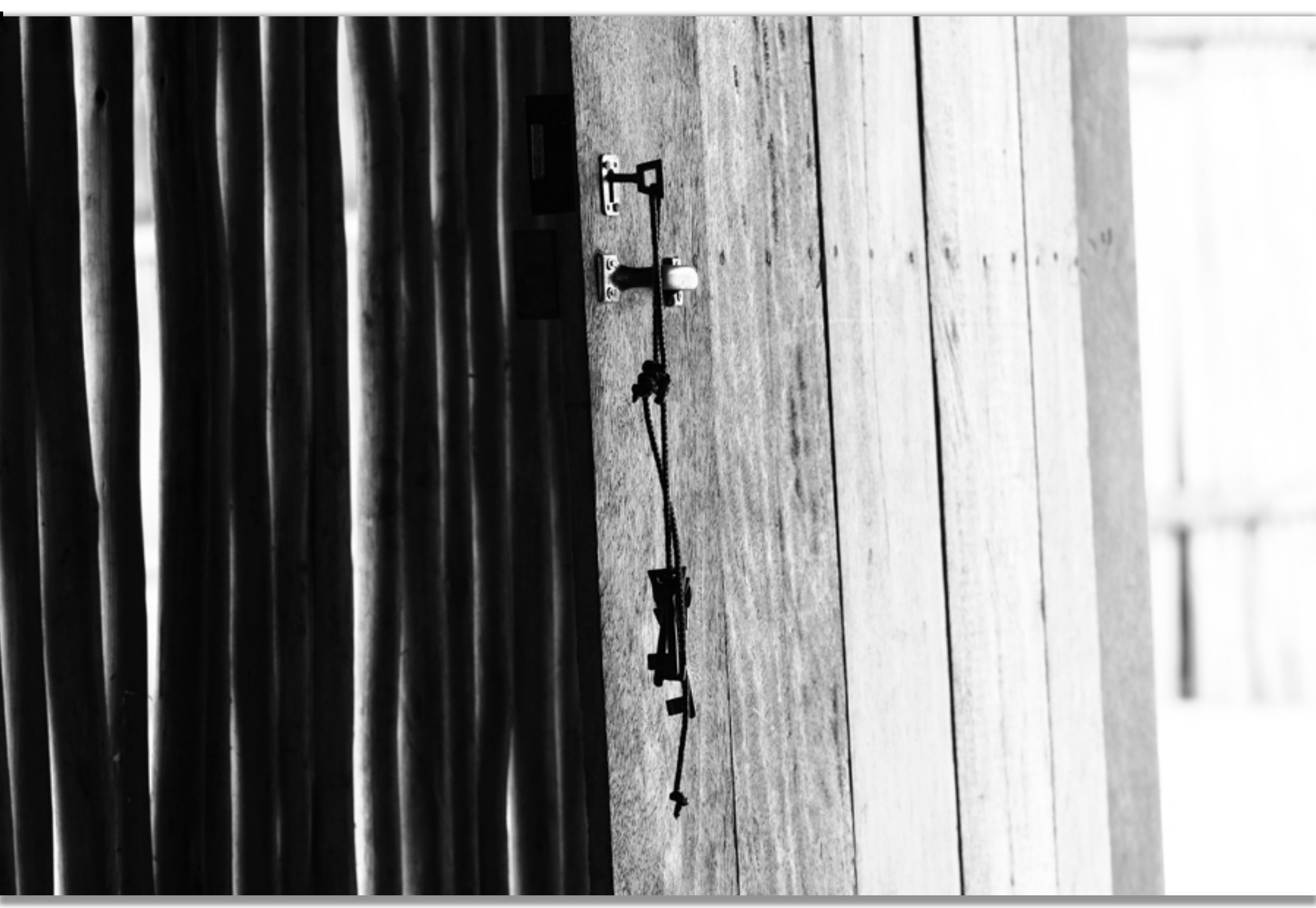

The door of the school 
PUPUNHA 


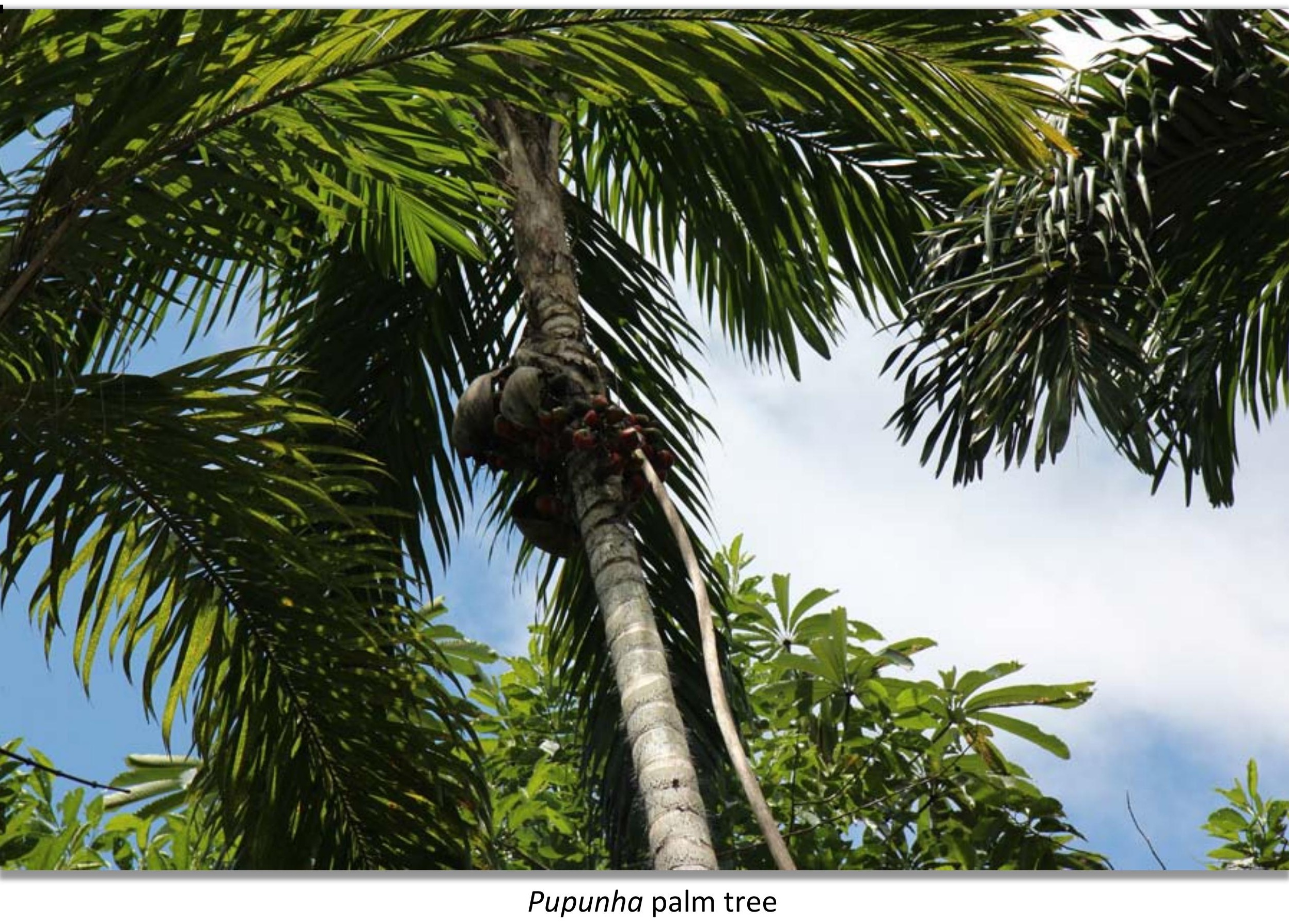




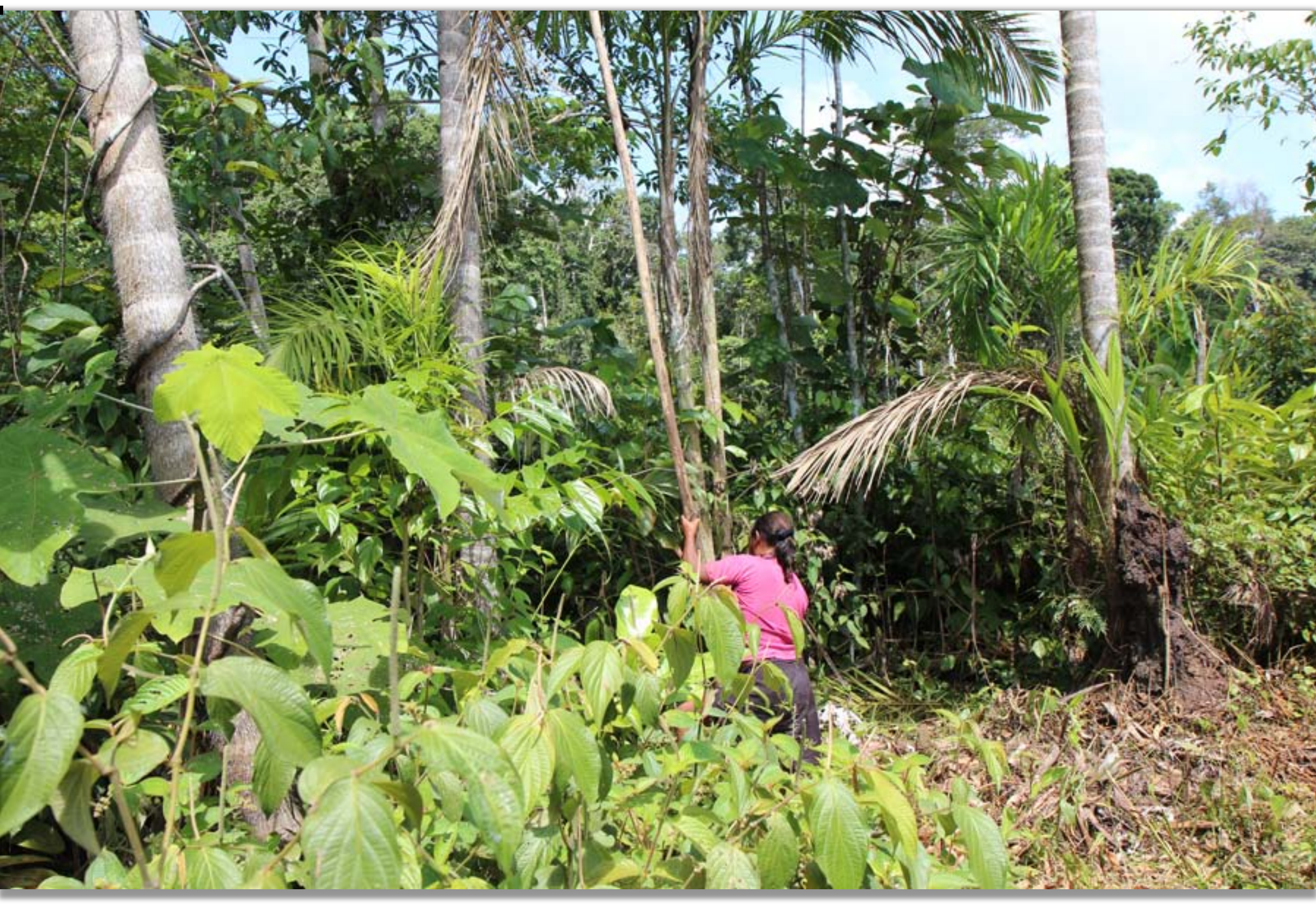




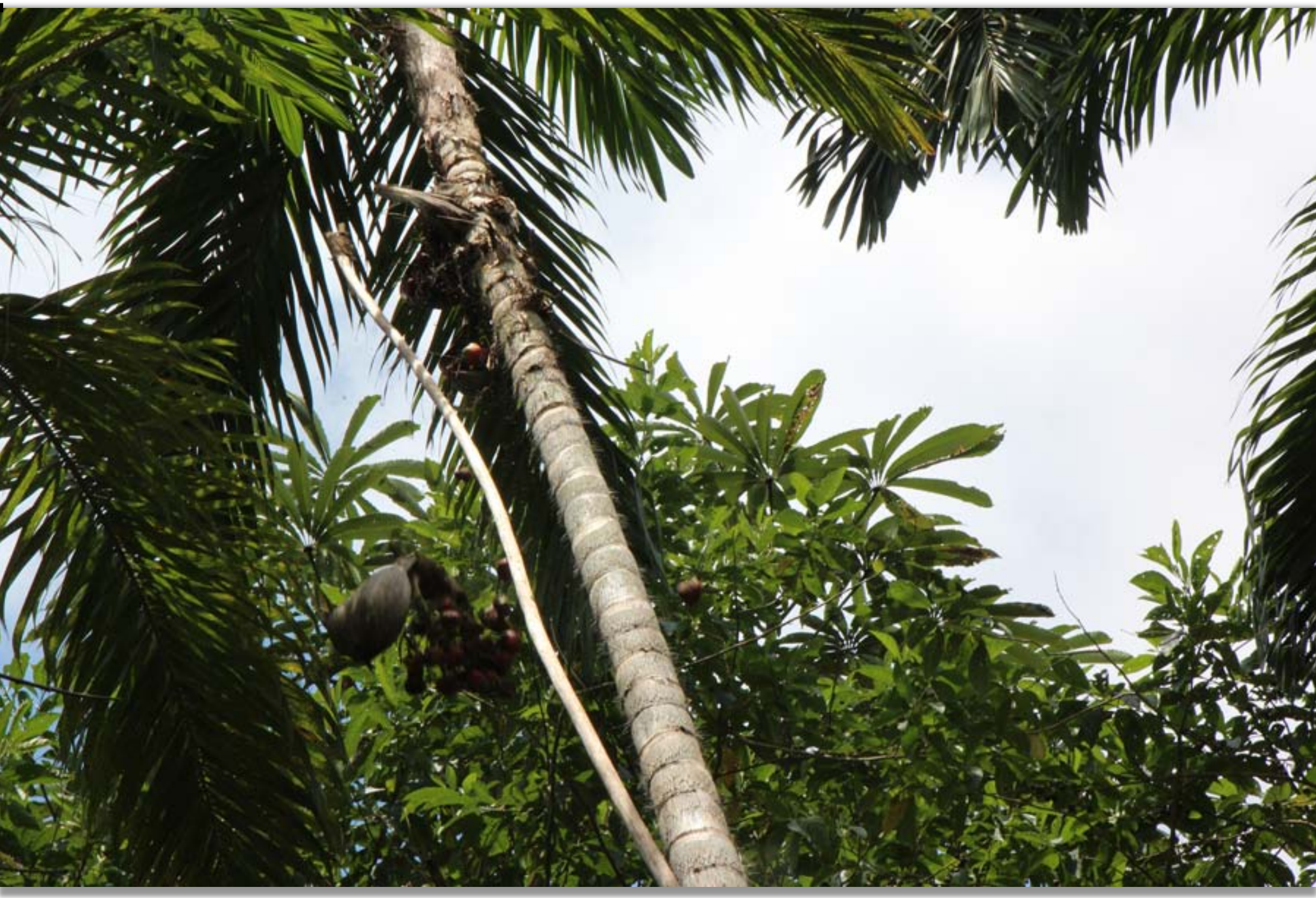

A large stick is necessary to collect pupunha 


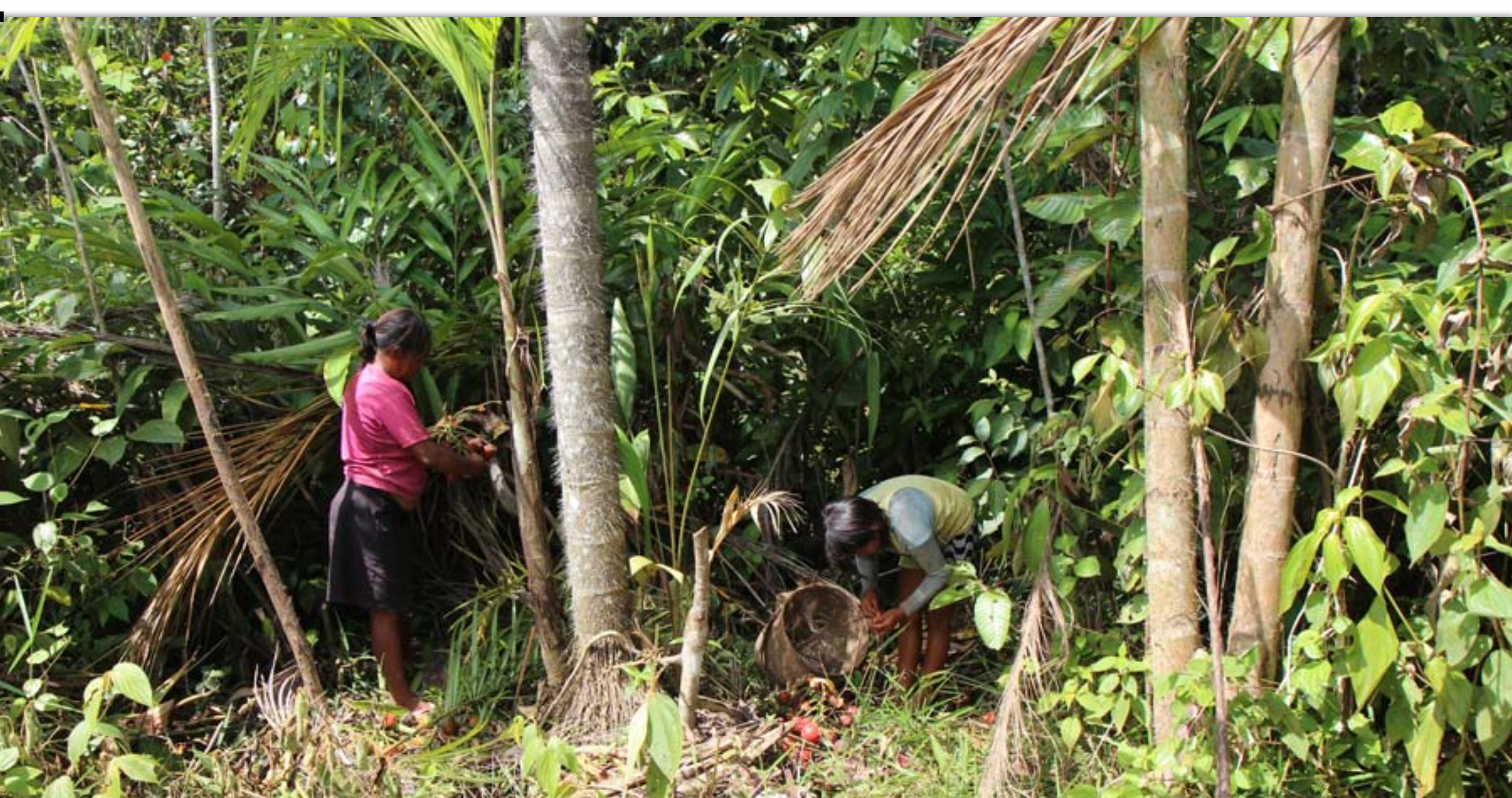

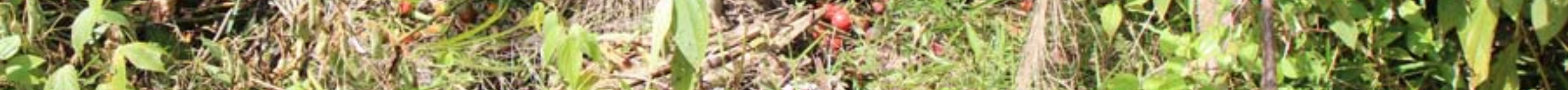

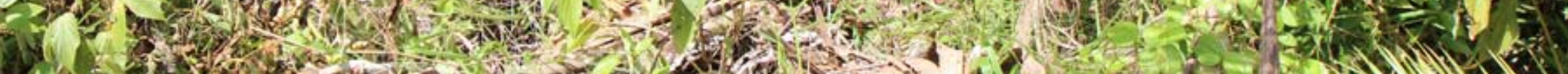

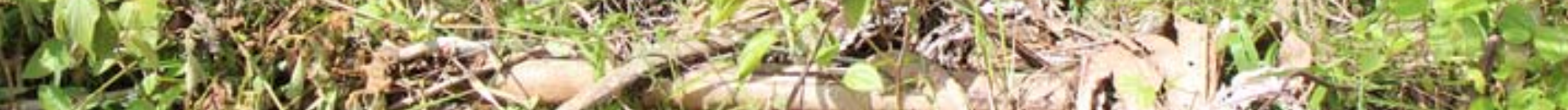

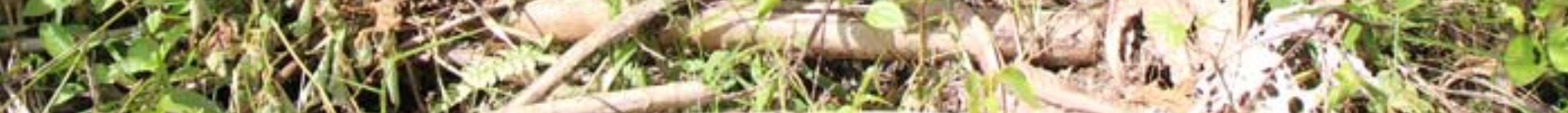

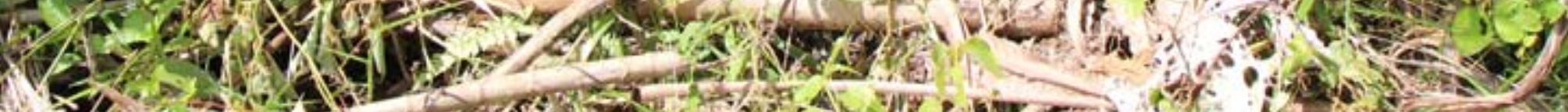

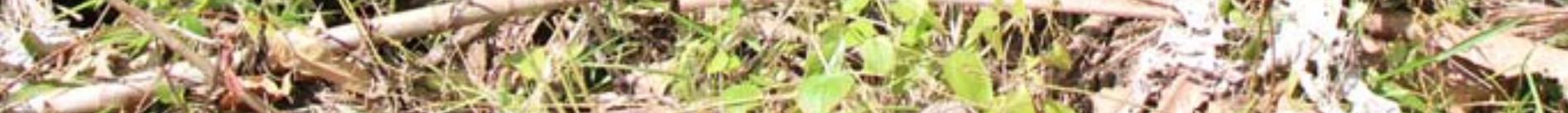

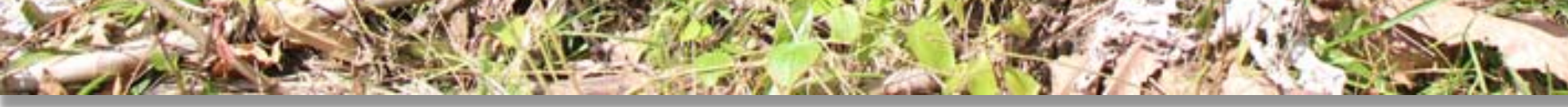




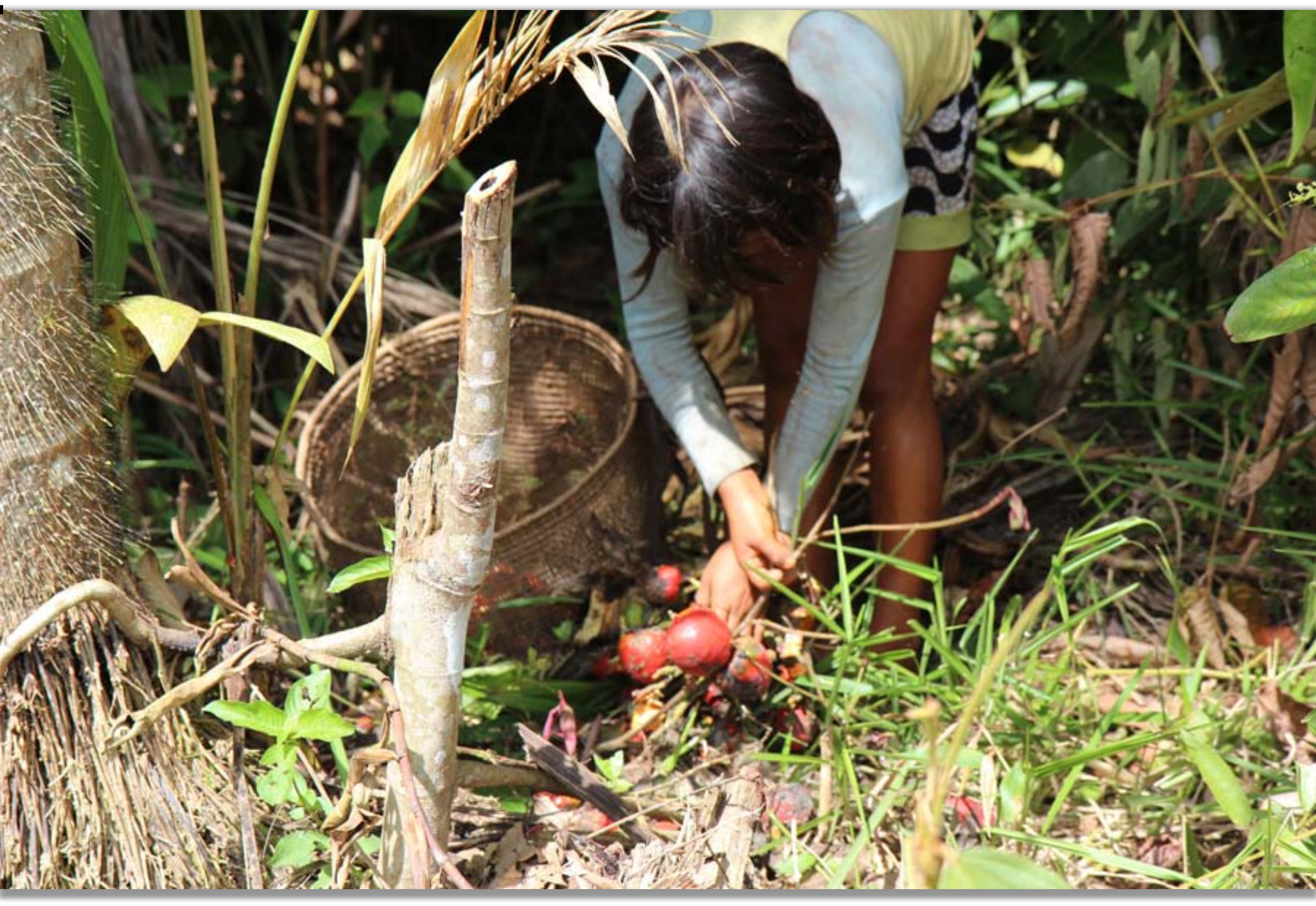




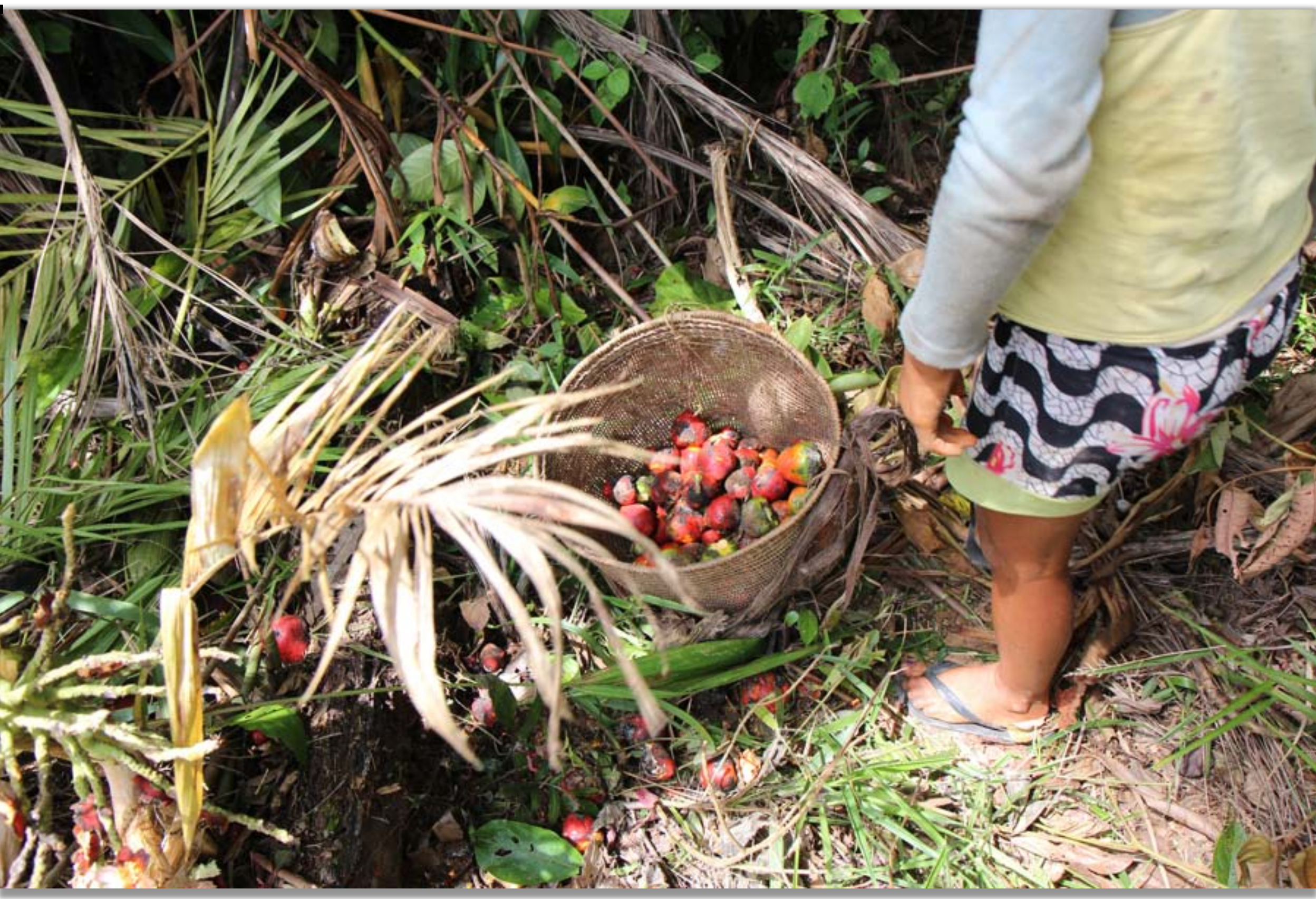




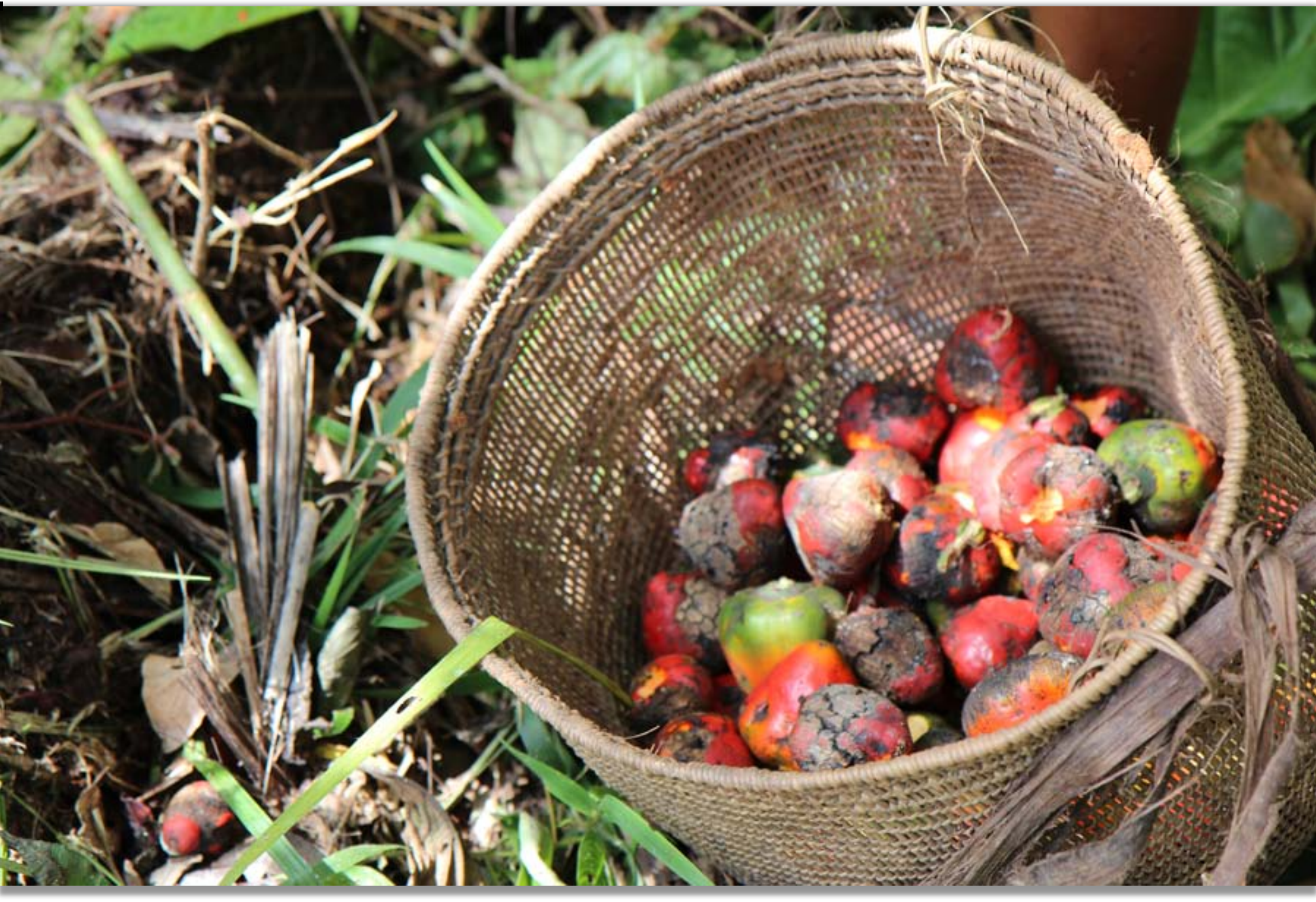




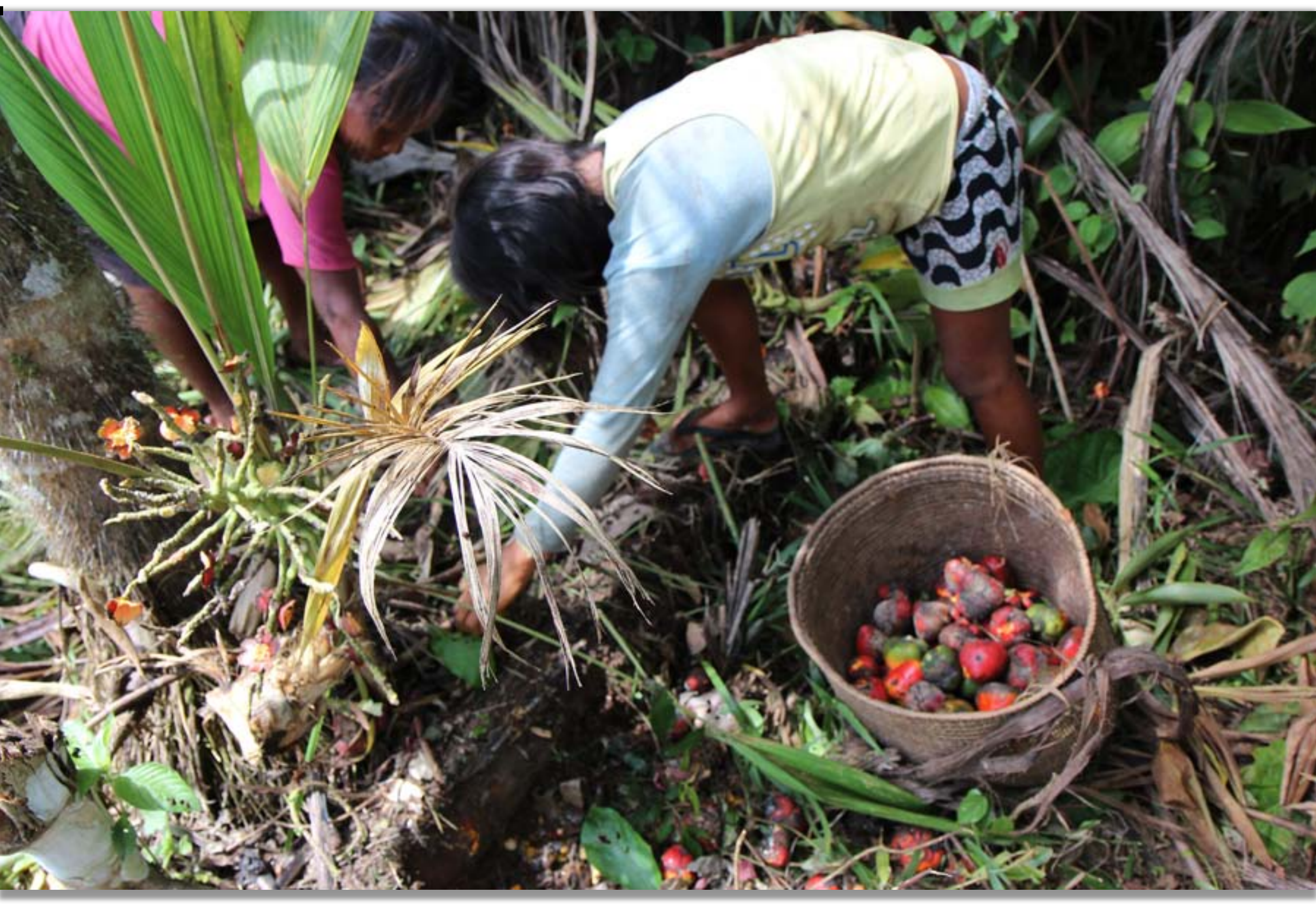




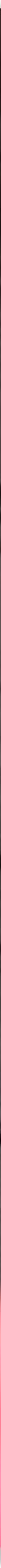

Pupunha palm hearts must be boiled for quite a long time 


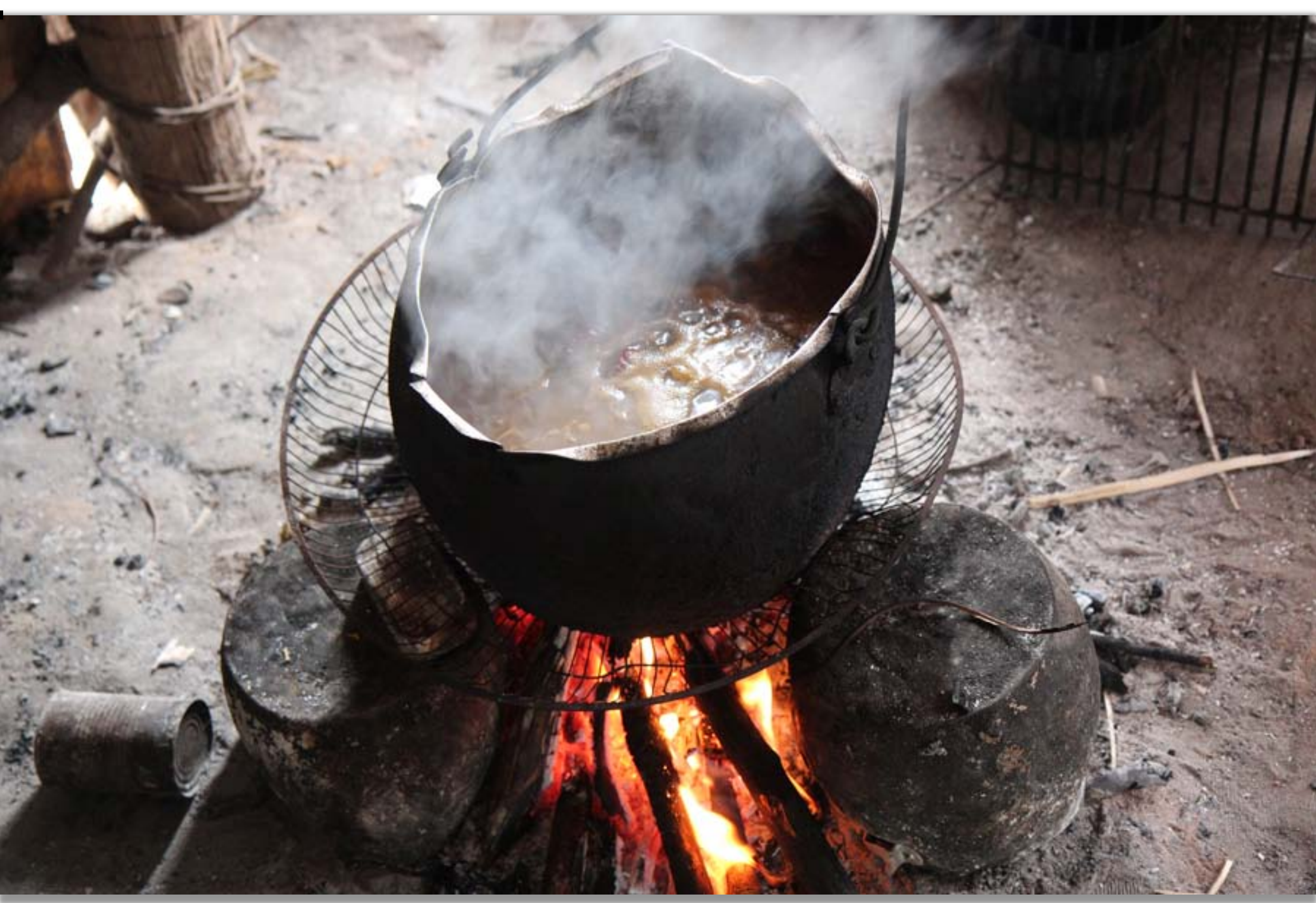




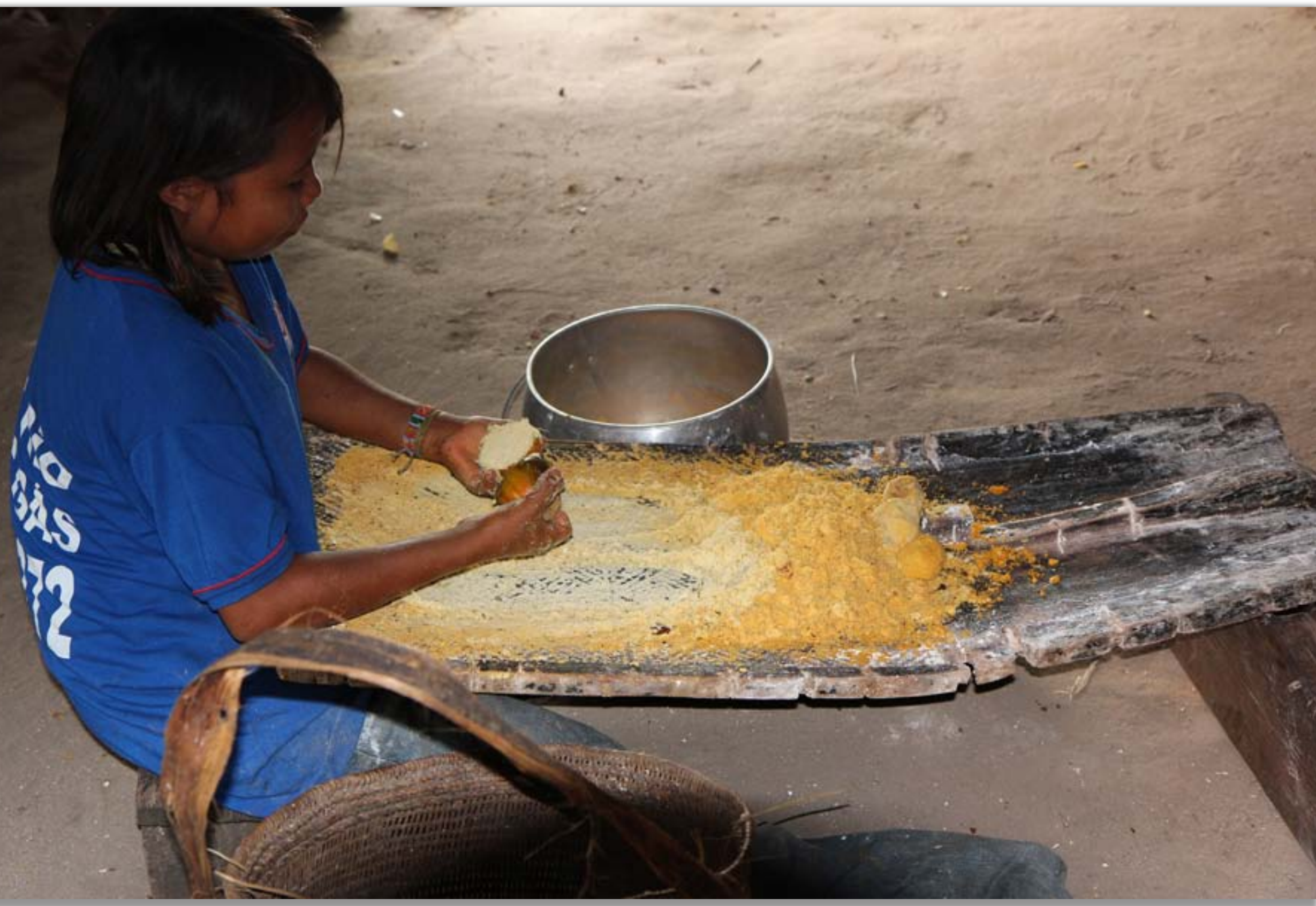

Carmen grates the cooked pupunha 


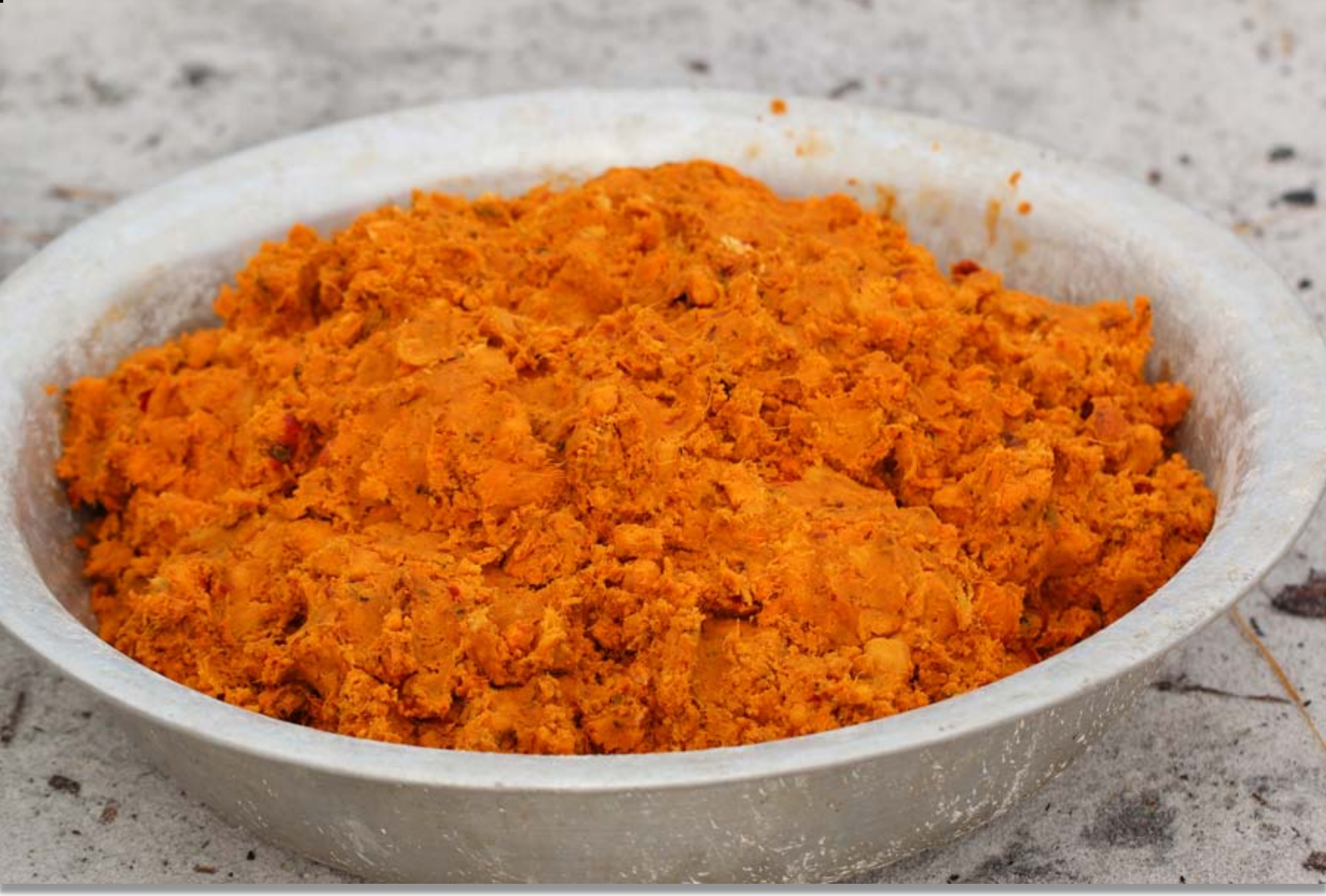

Pupunha may be used to make juice or it may be added to caxiri 
The manioc civilization 


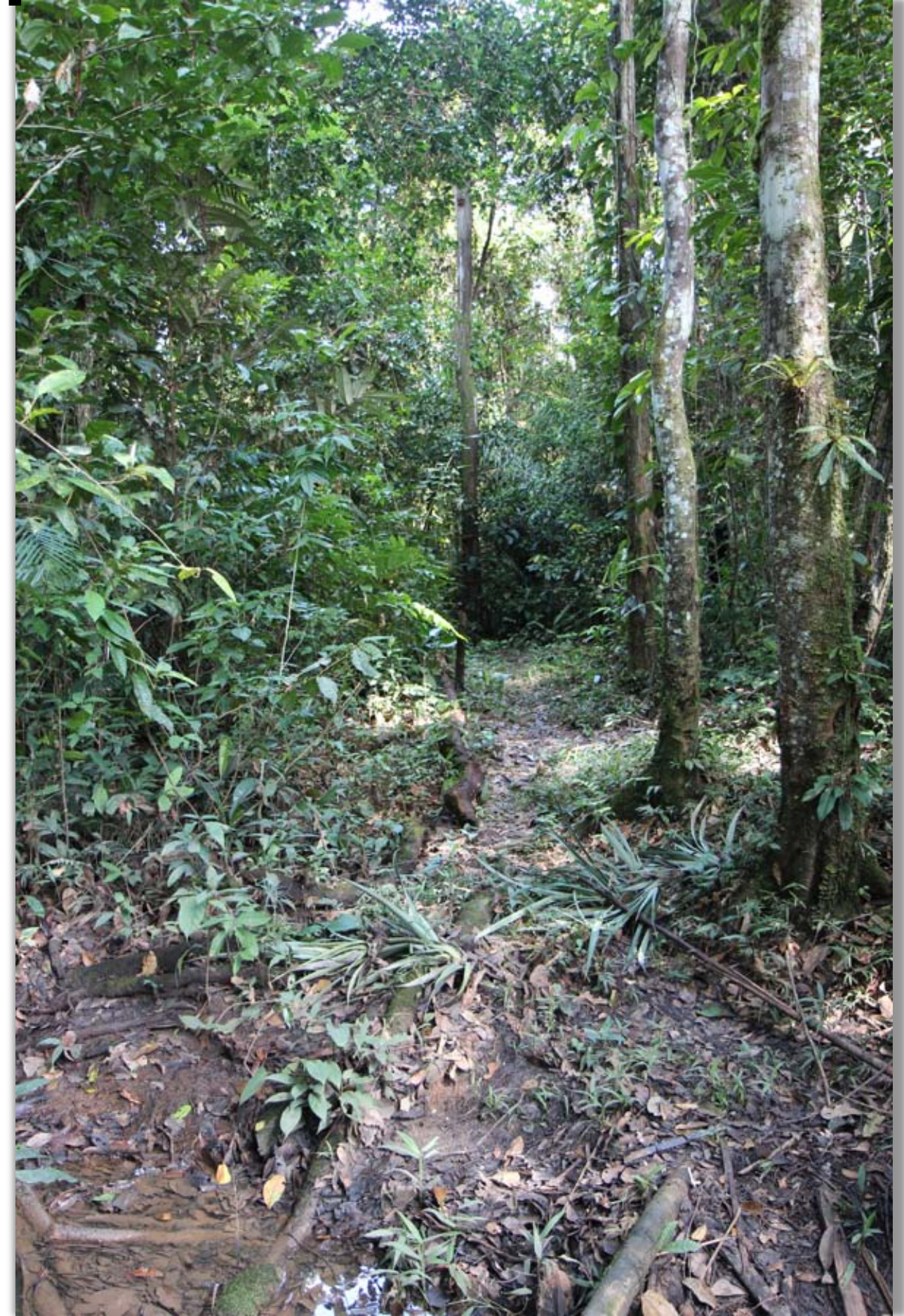




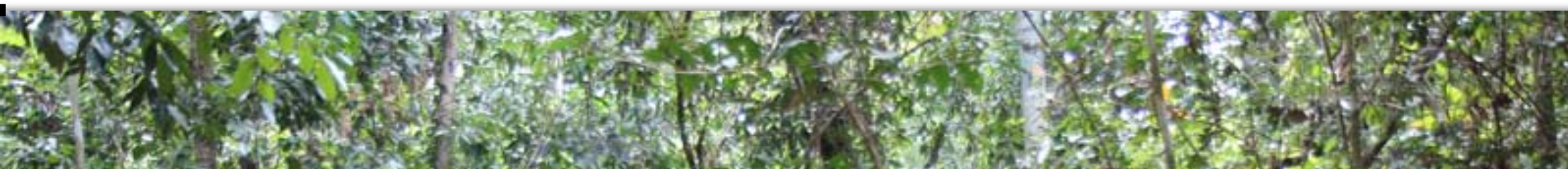

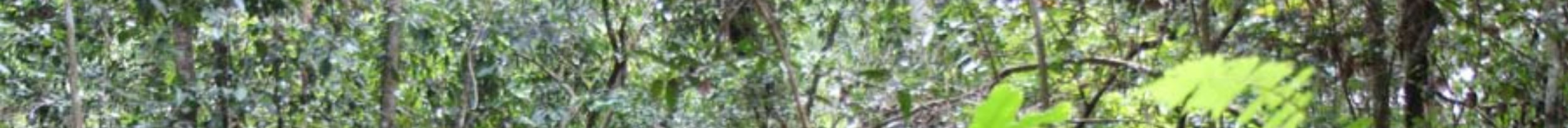

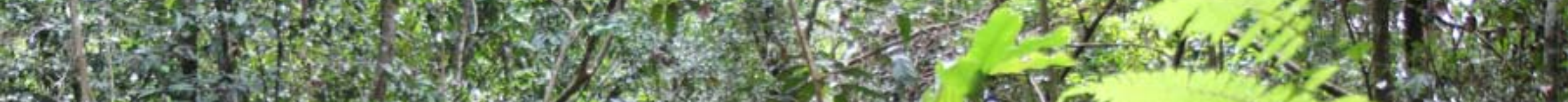

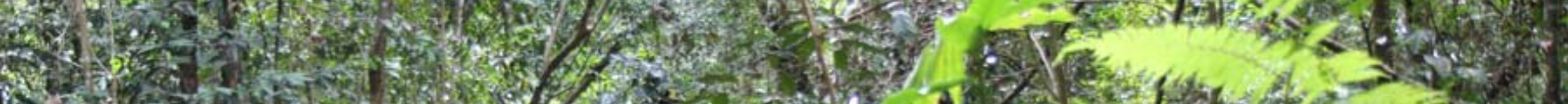

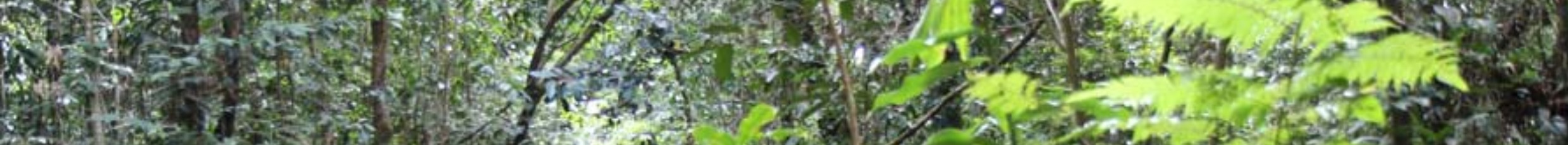

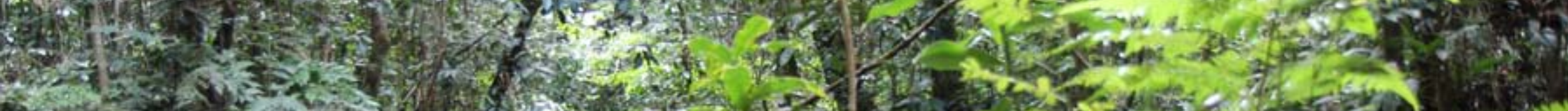

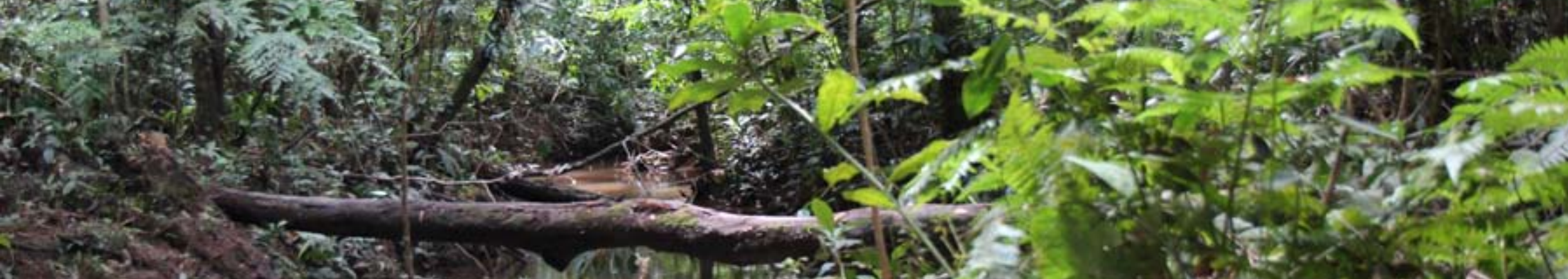

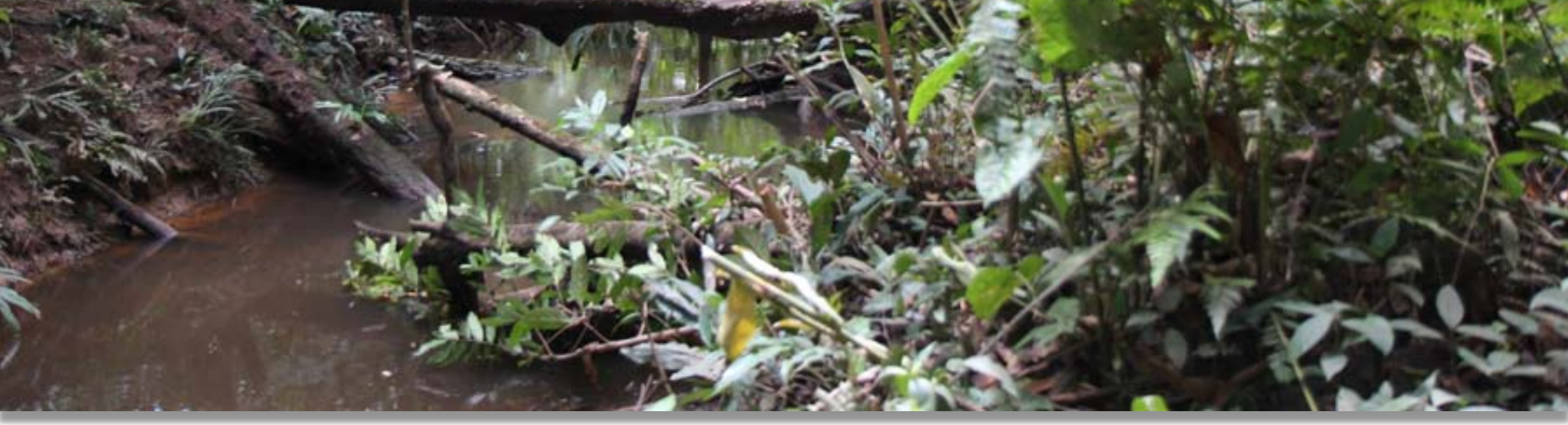

To reach the garden one must cross some bridges like this 

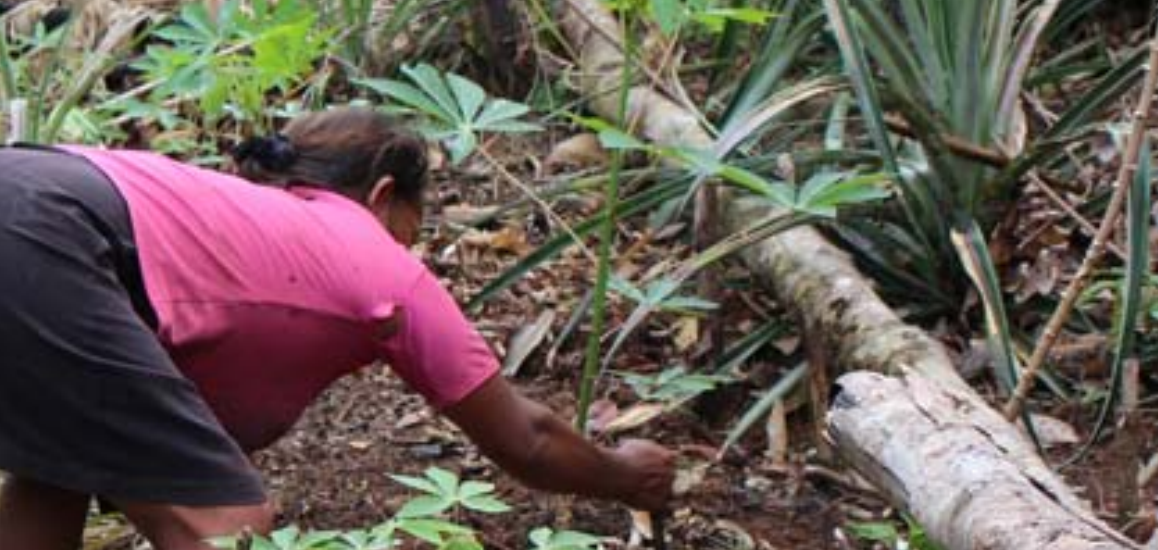

$-10(2)$

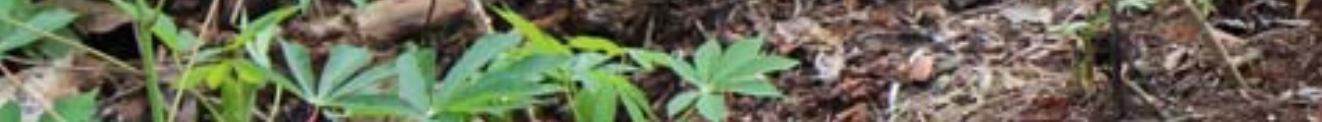

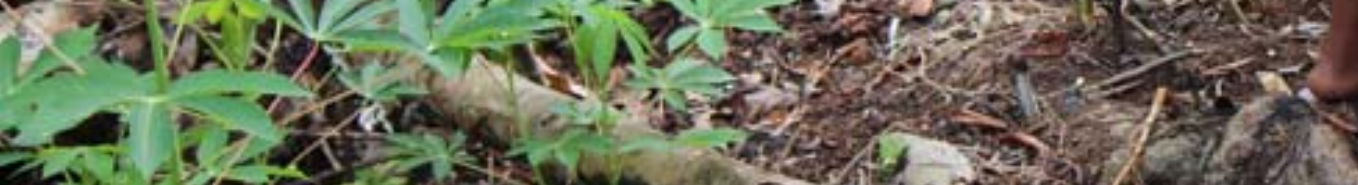

56 री

B.

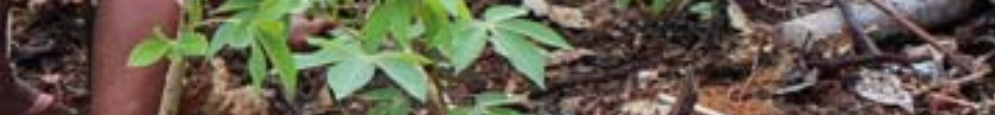
inats

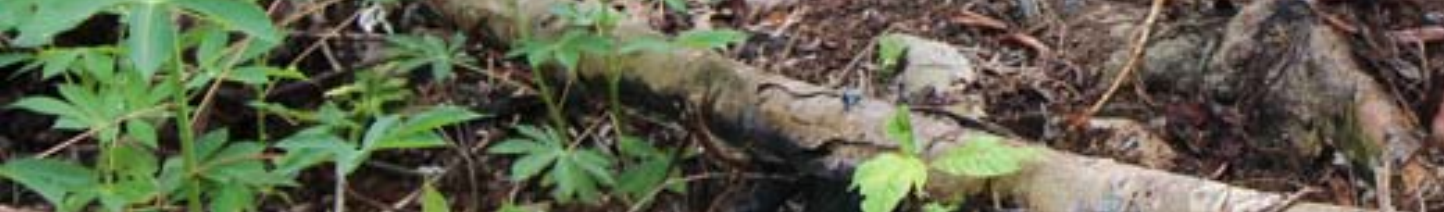
D. (c)

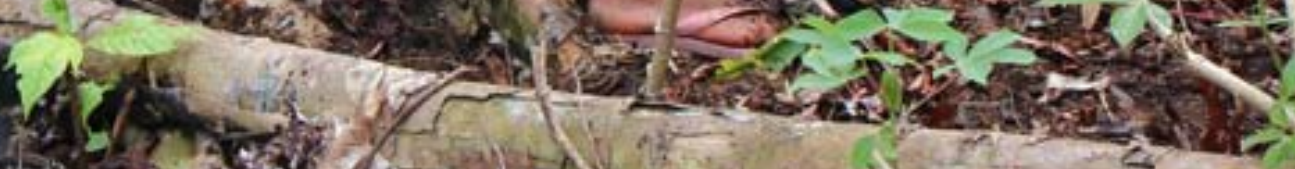
1. 2 a

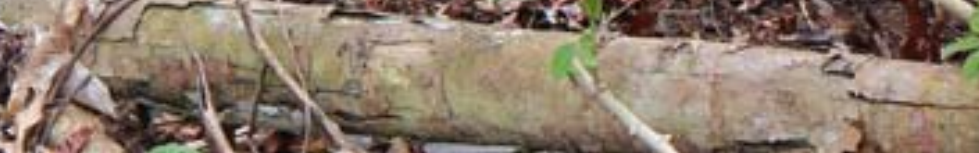
bunin ans Isabel plants and collects manioc in her garden 


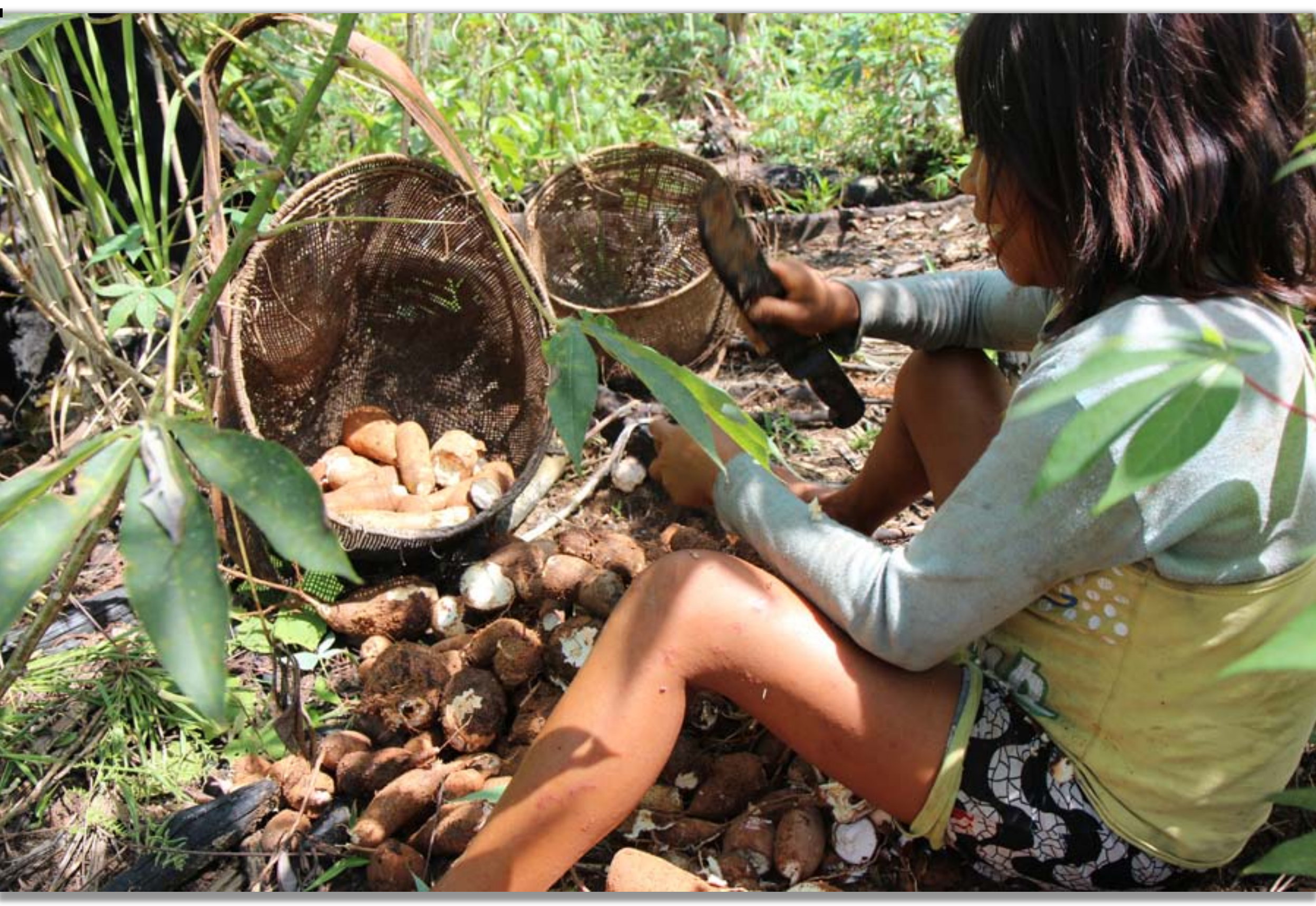




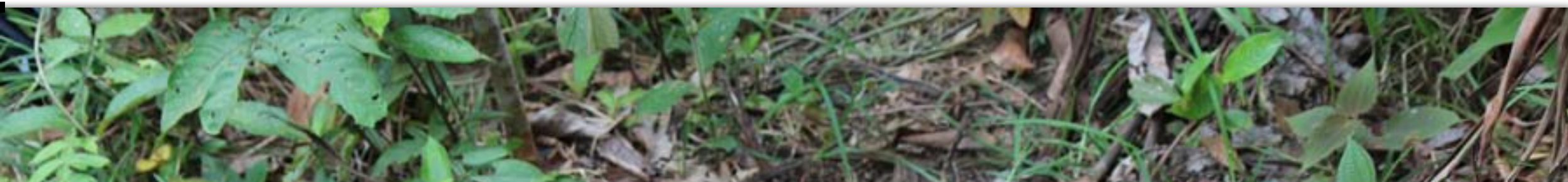

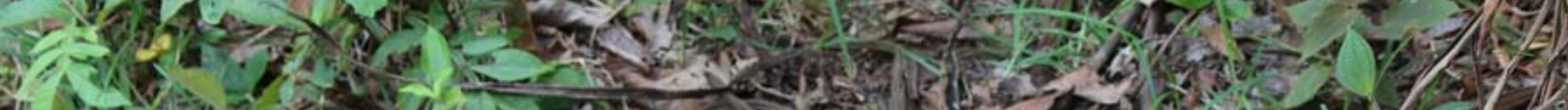

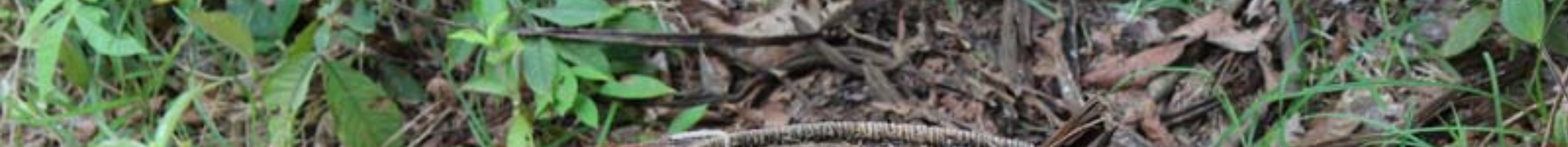

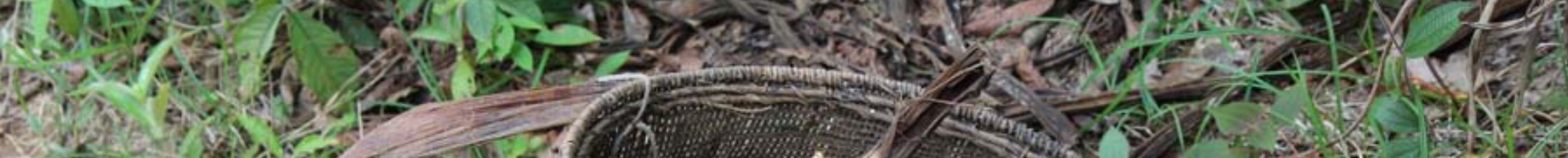
$10=0(2)$ 2.

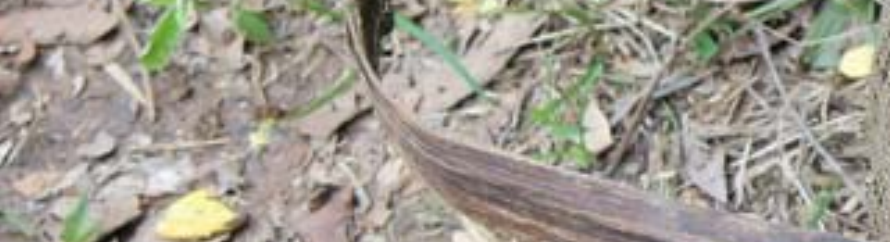

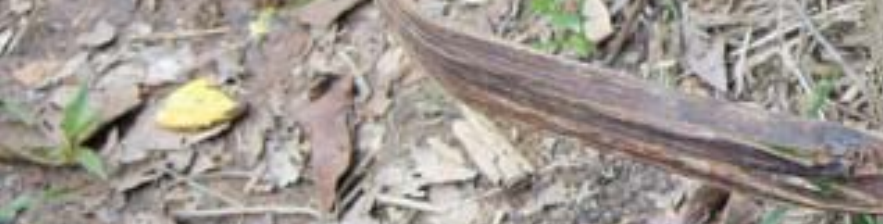
32710 1356) $x=2-2 x=0$

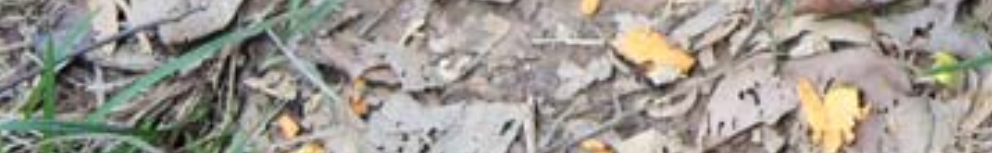

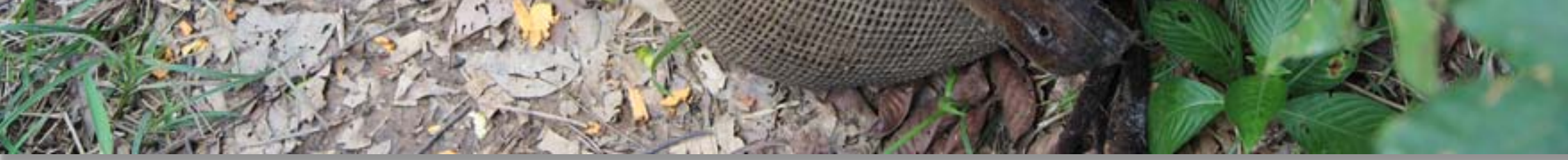




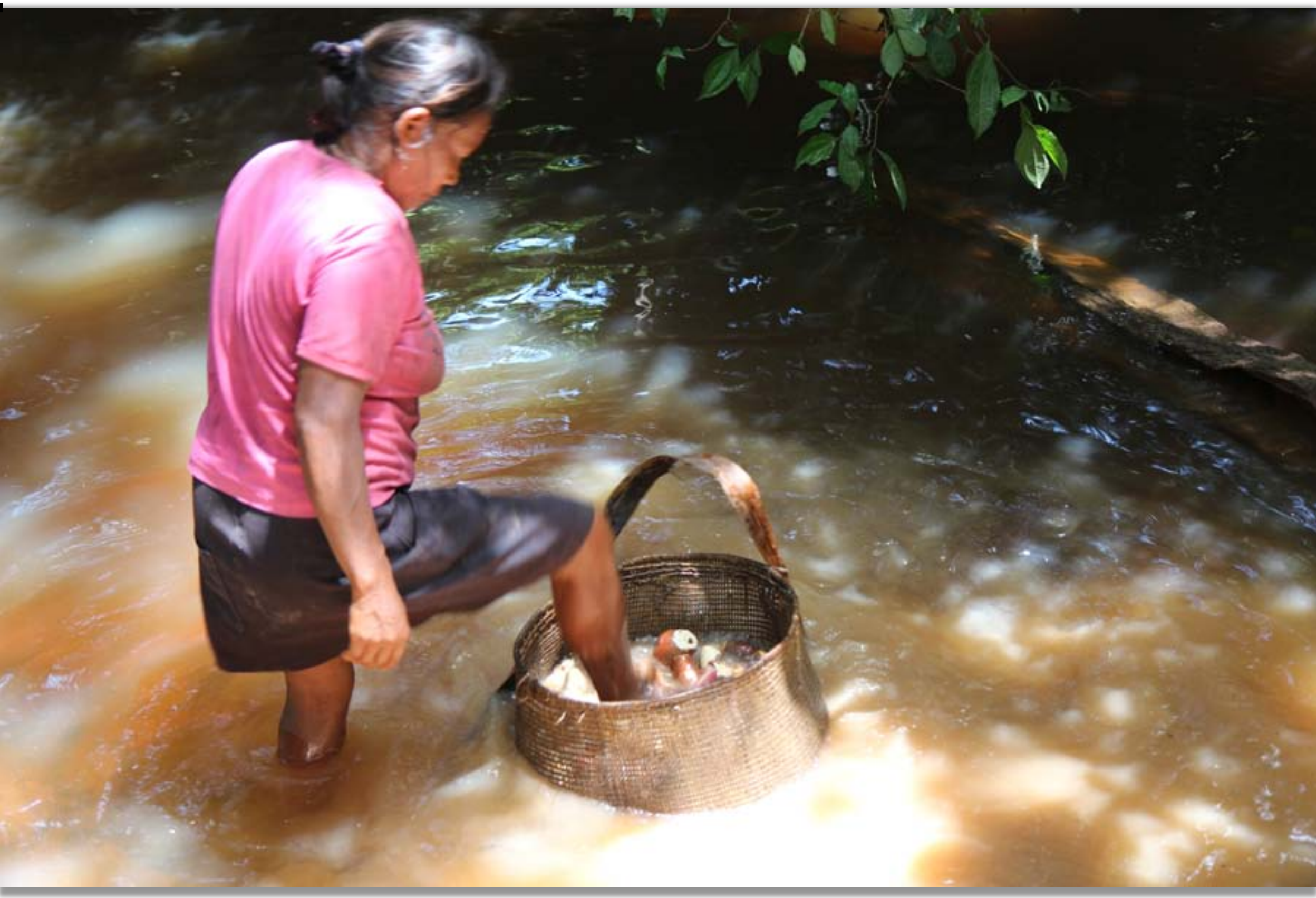

On her way back she washes the manioc in the river 


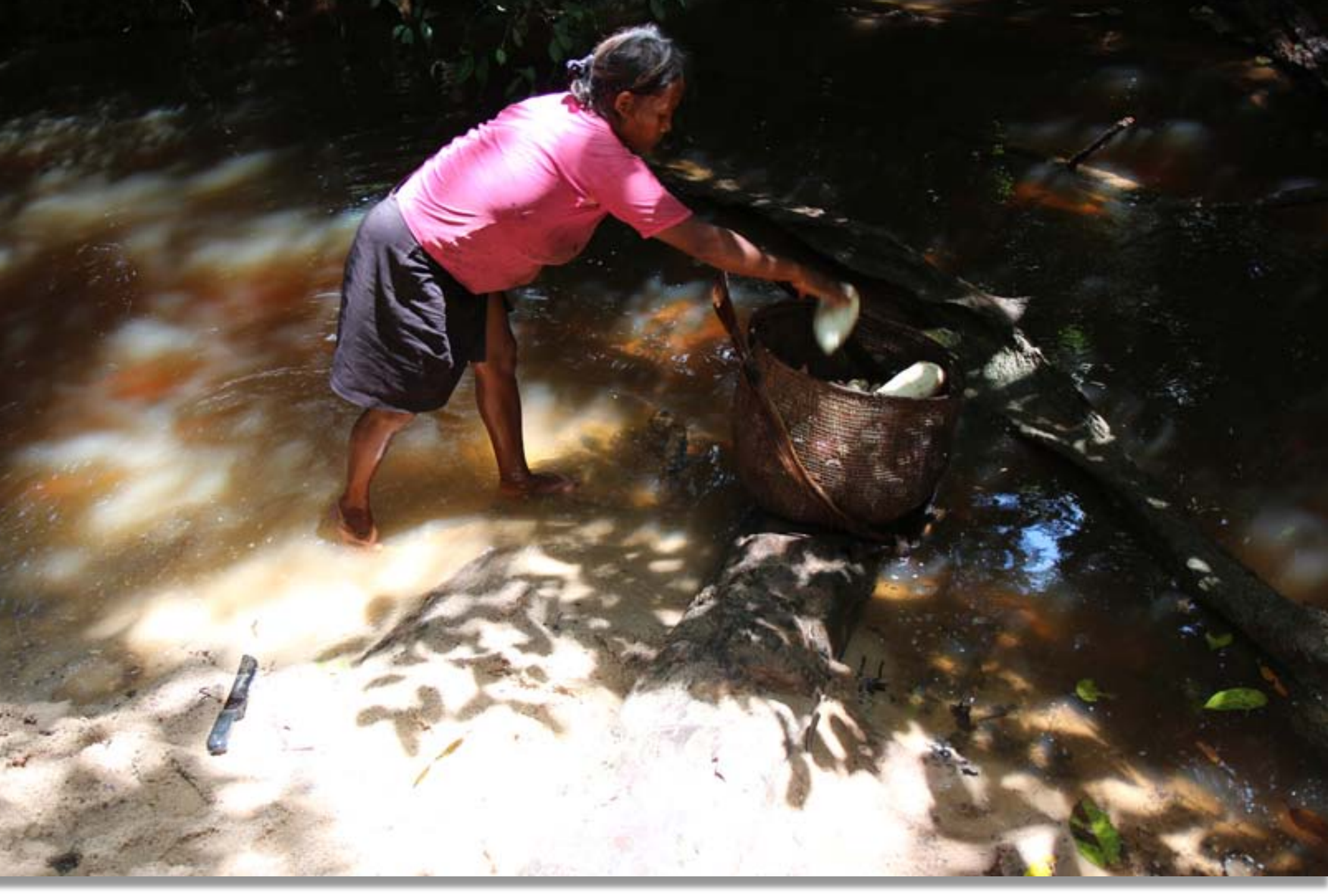

$-3045$

- ras

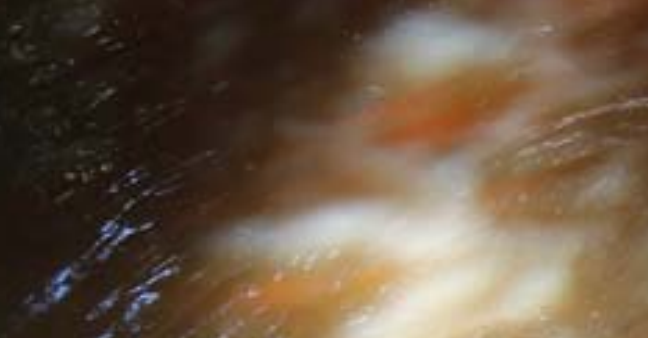

. 


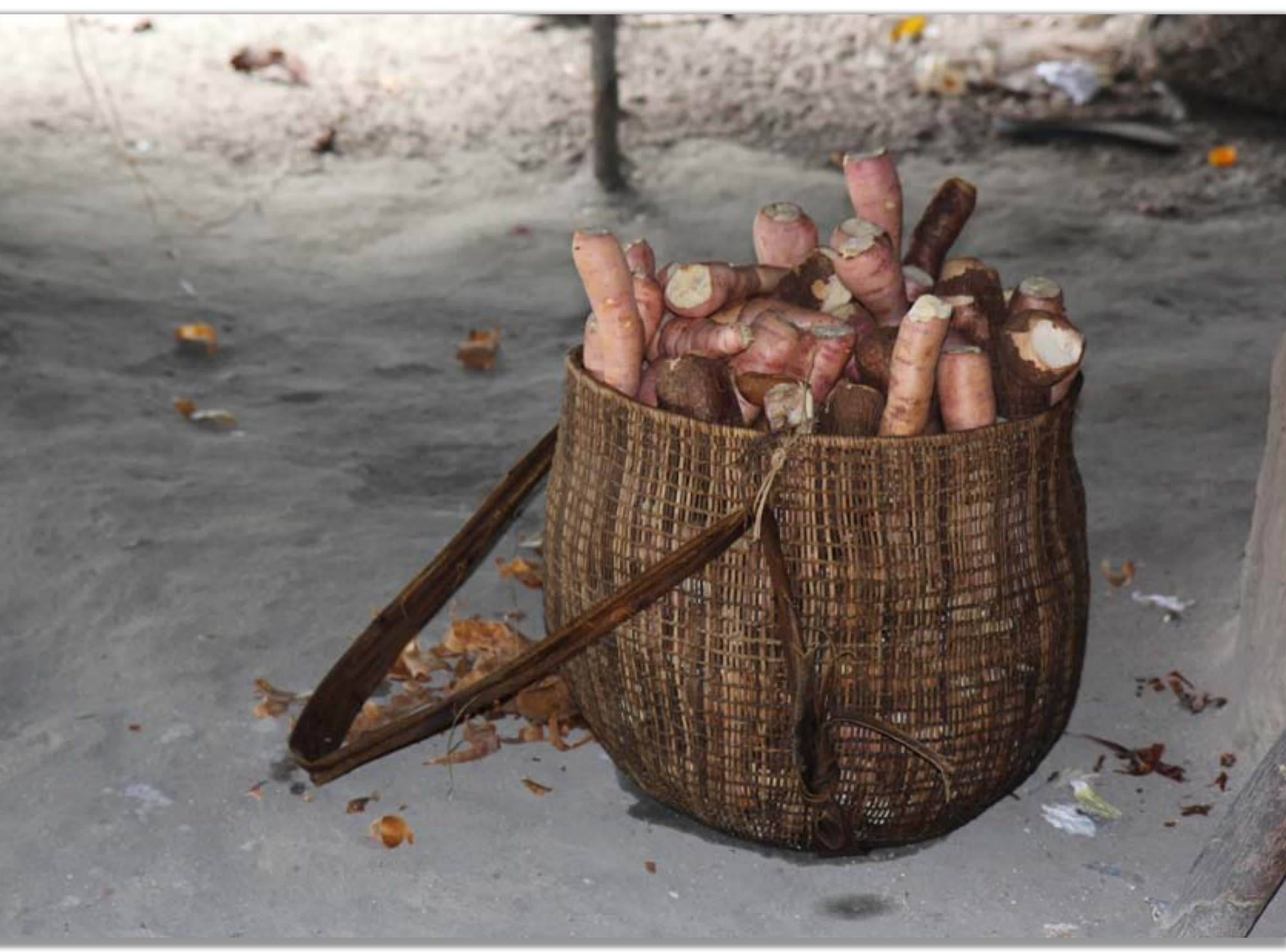




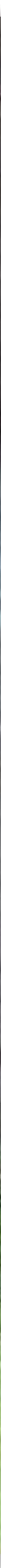

Men are in charge of making the base to support the manioc grater 


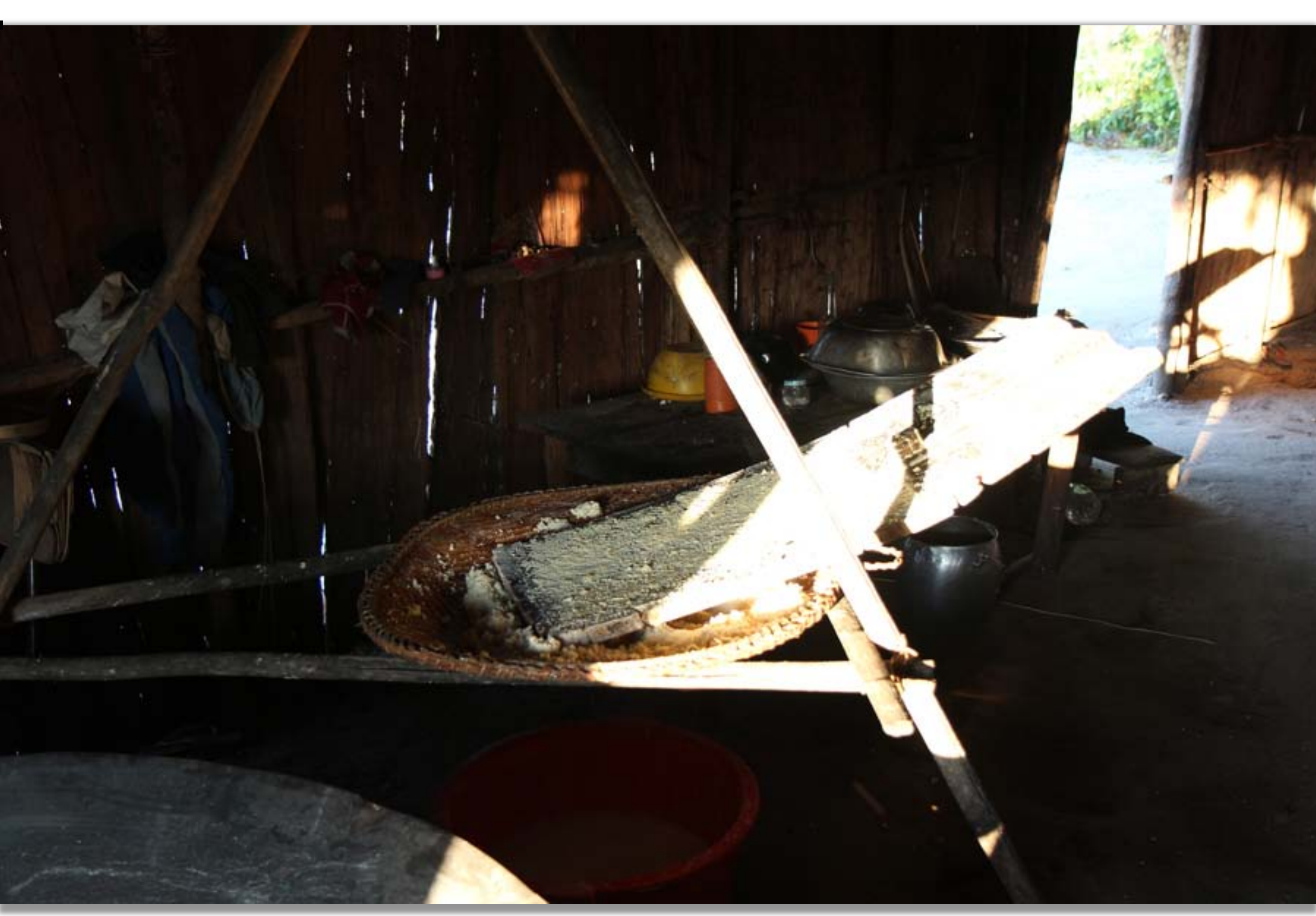




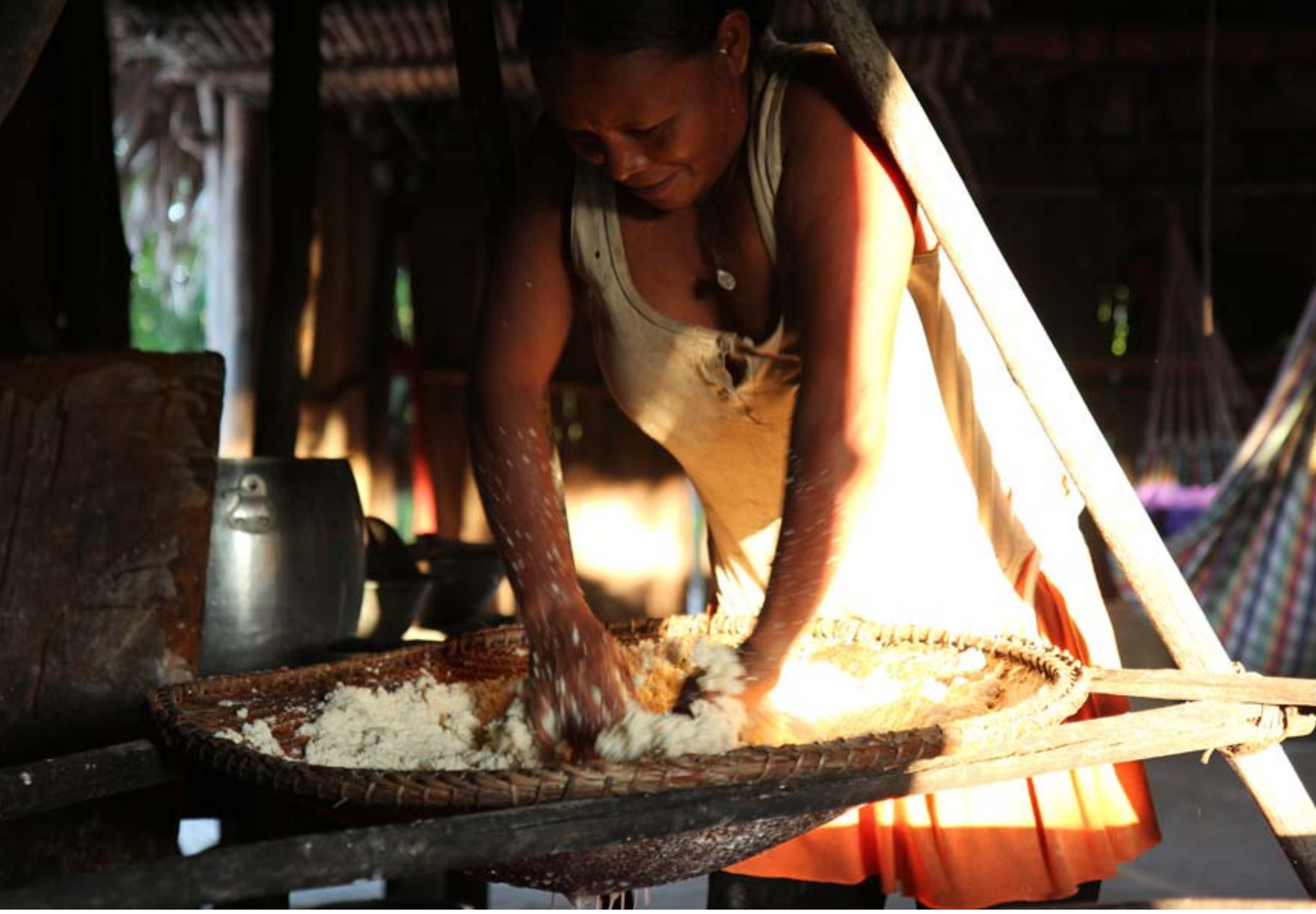




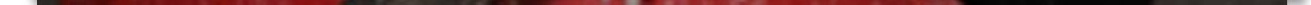




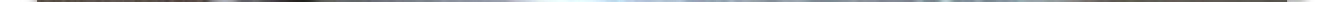




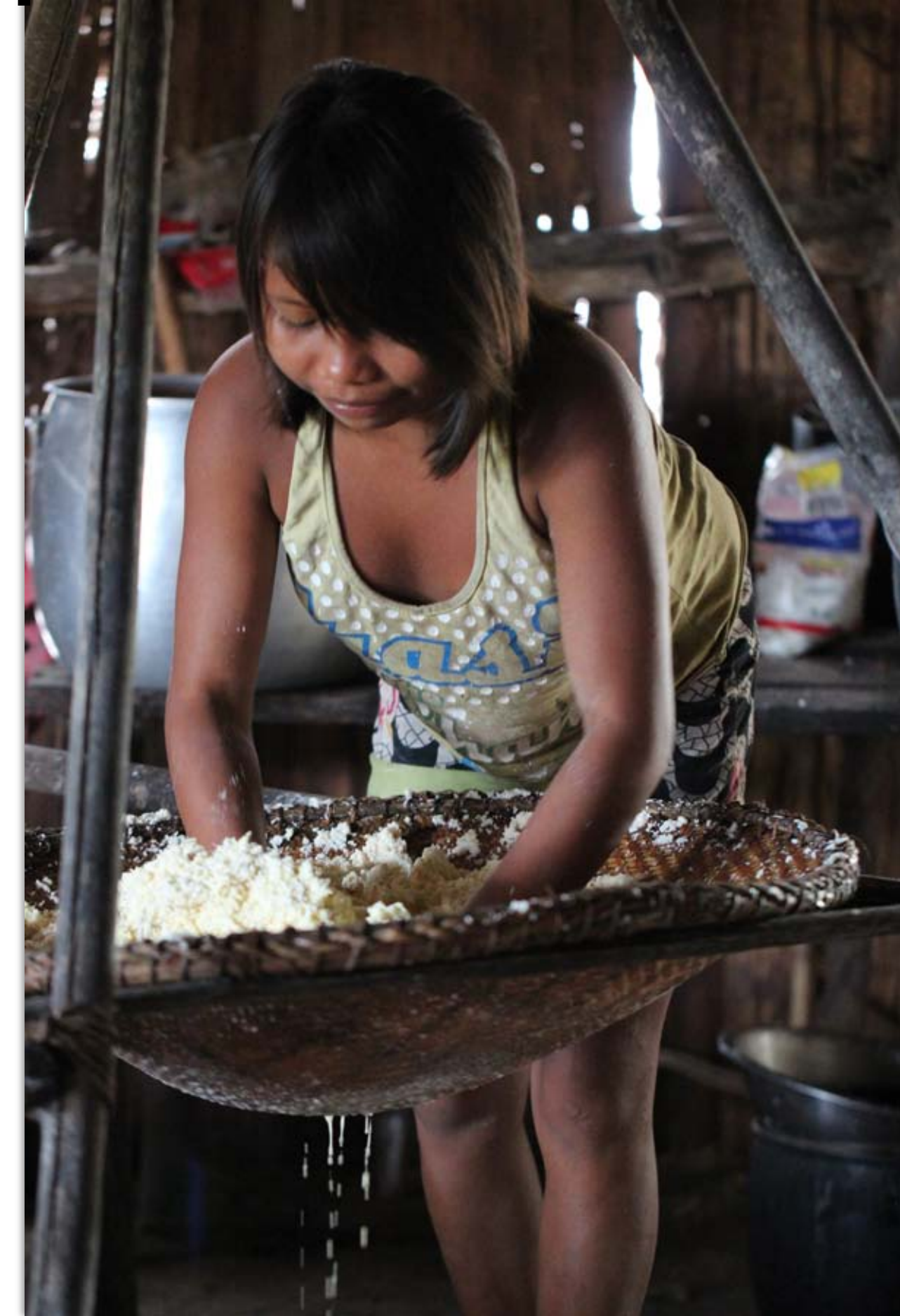




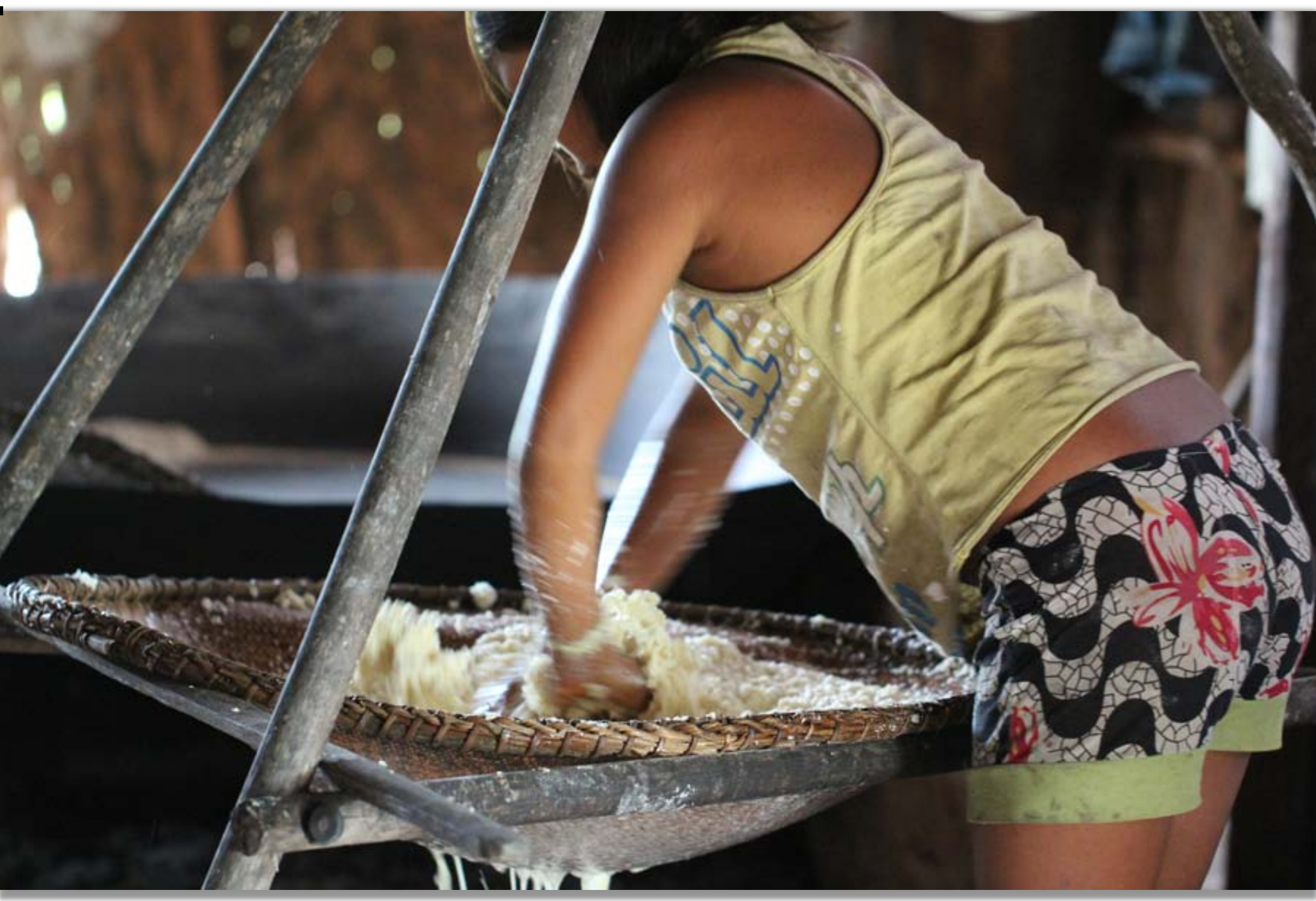




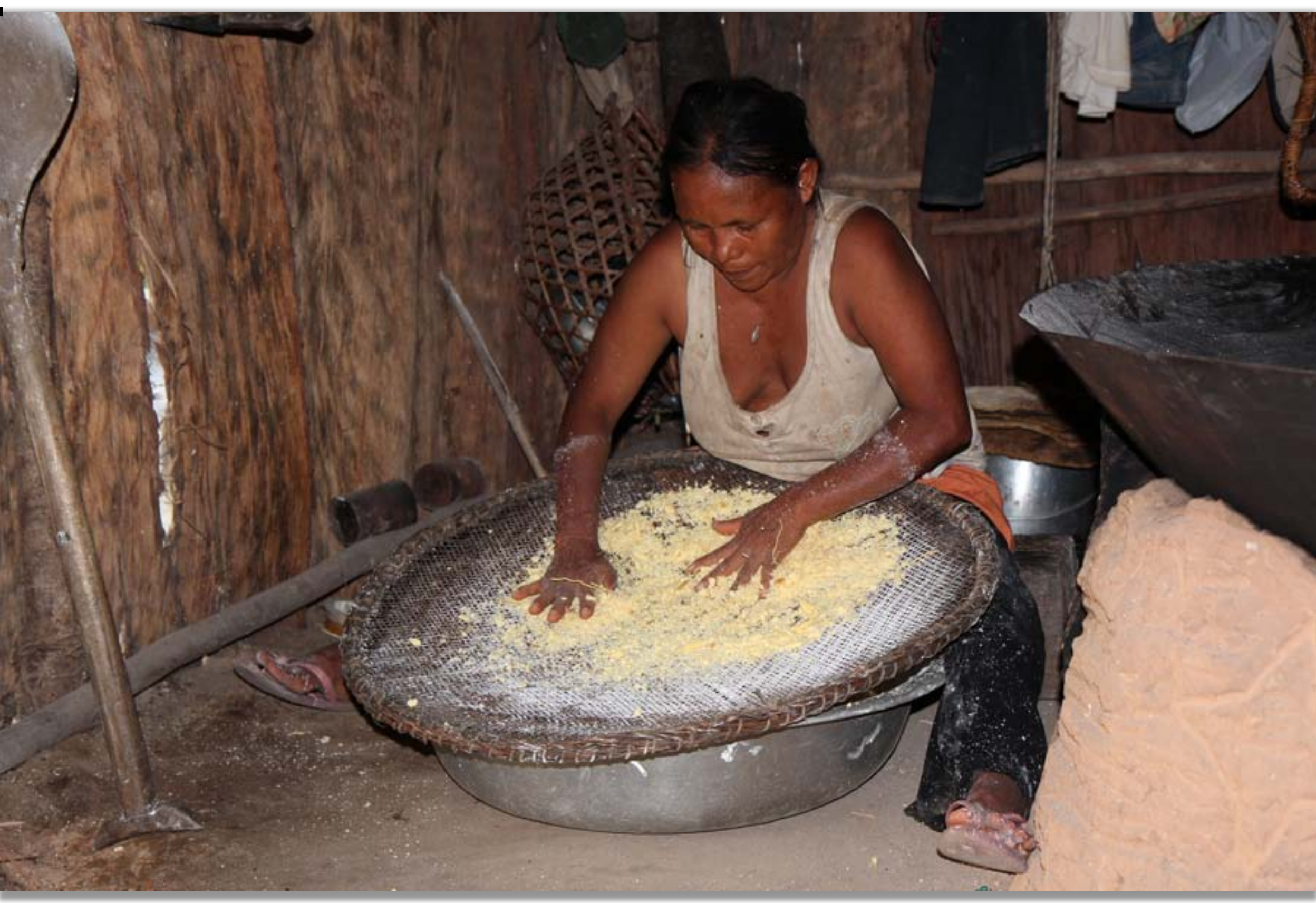




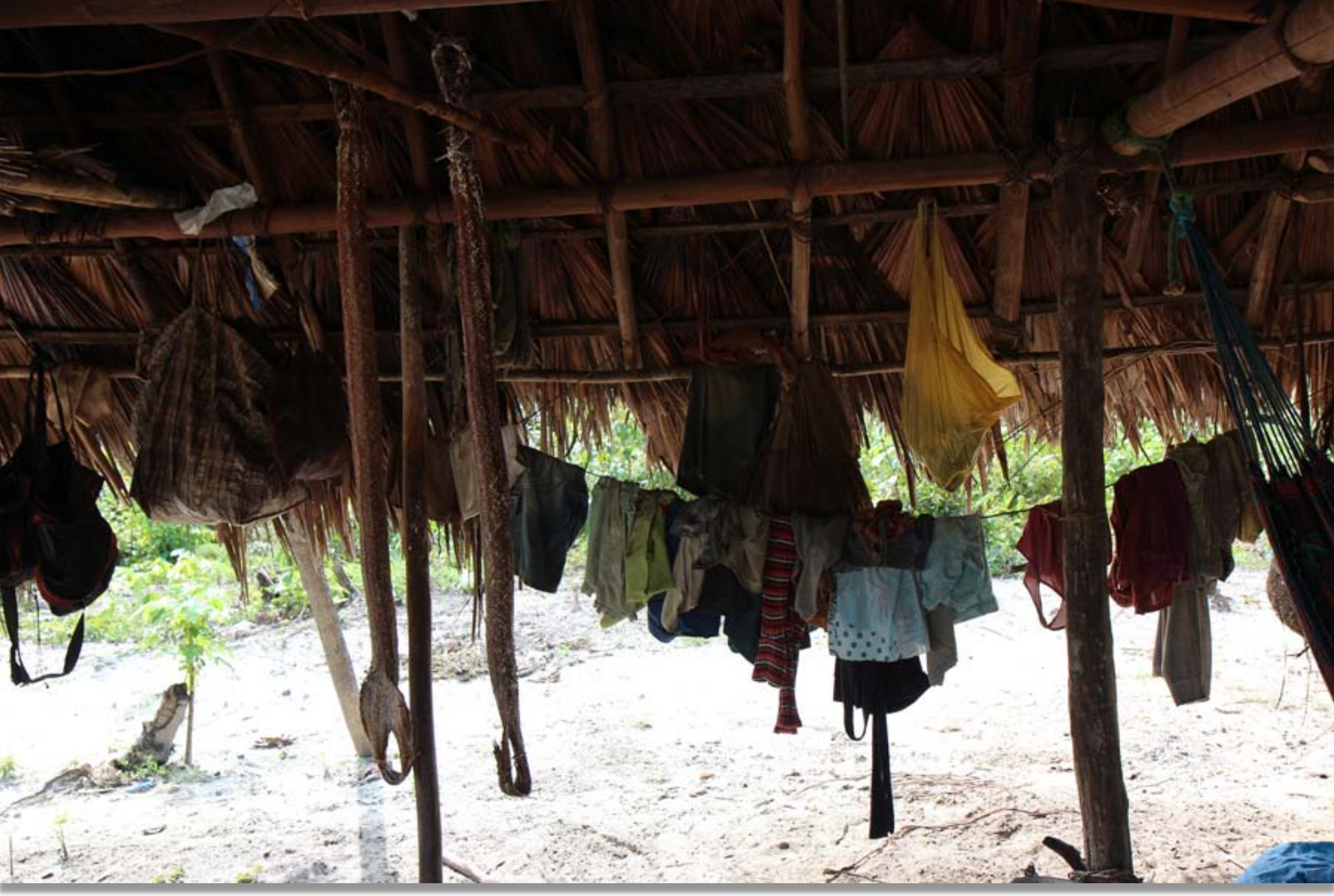




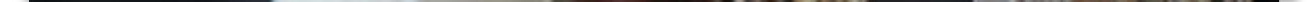




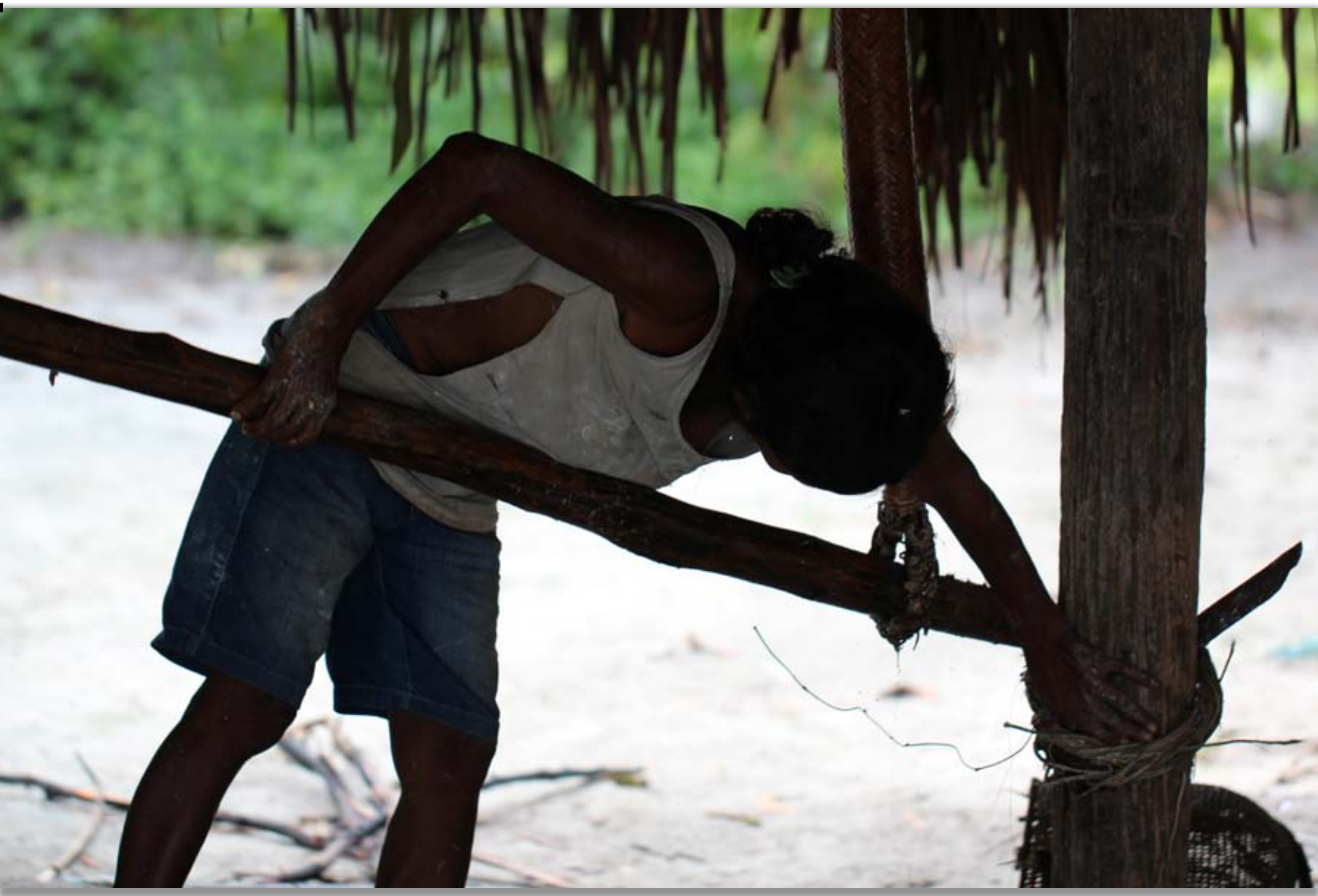

The tipiti is used to take the poison out of some types of manioc 


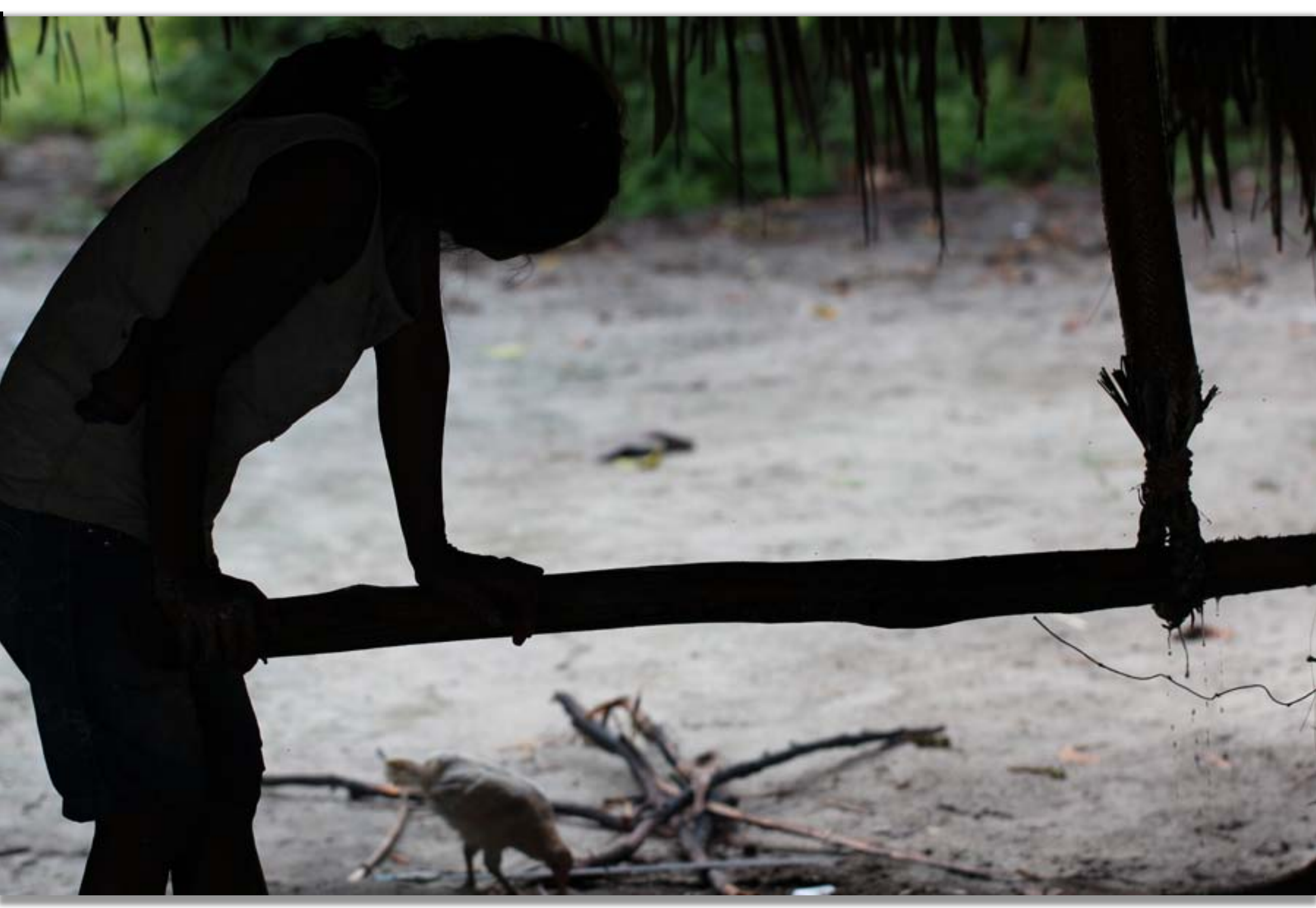



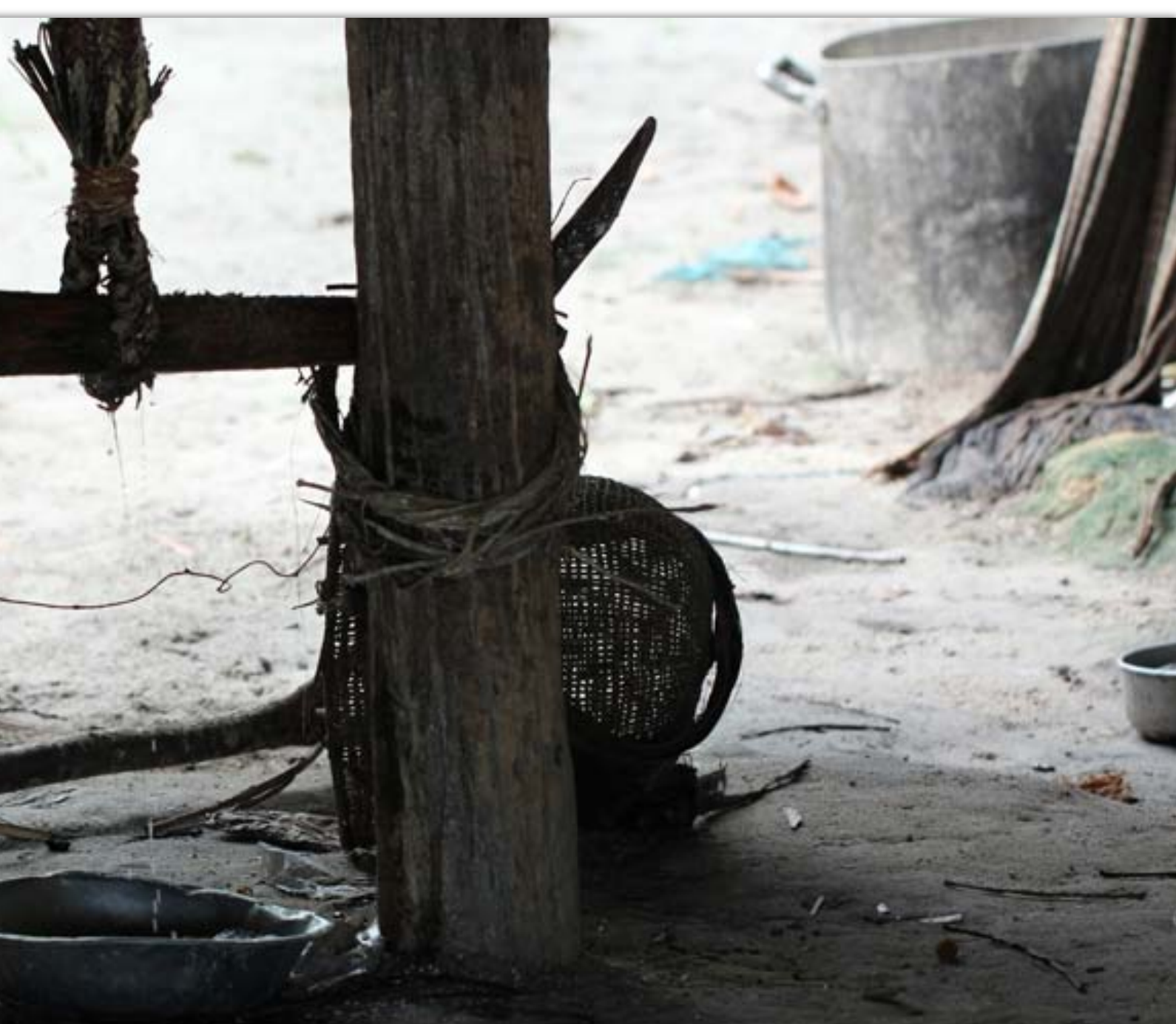

The manioc poison drips into a basin 


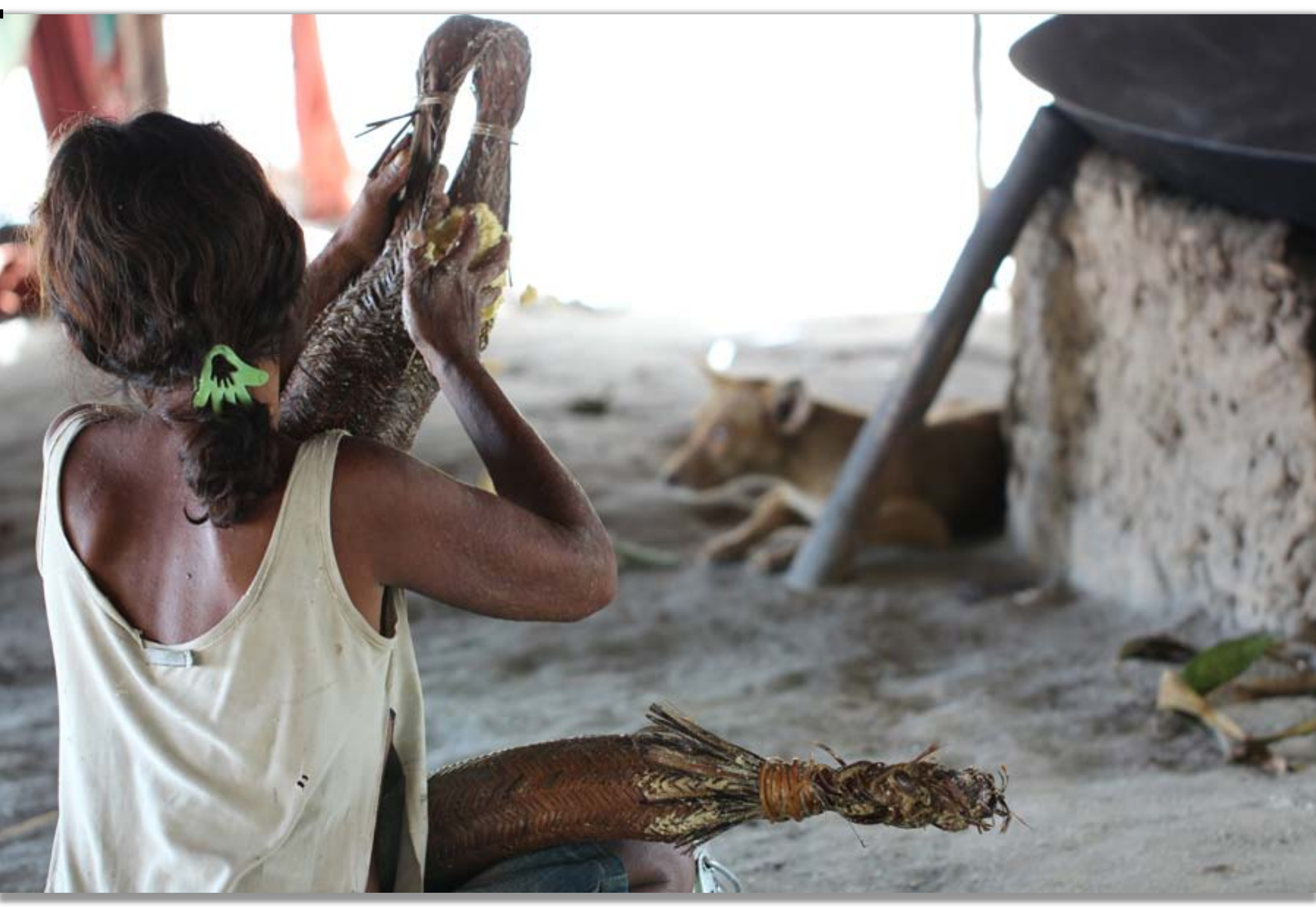




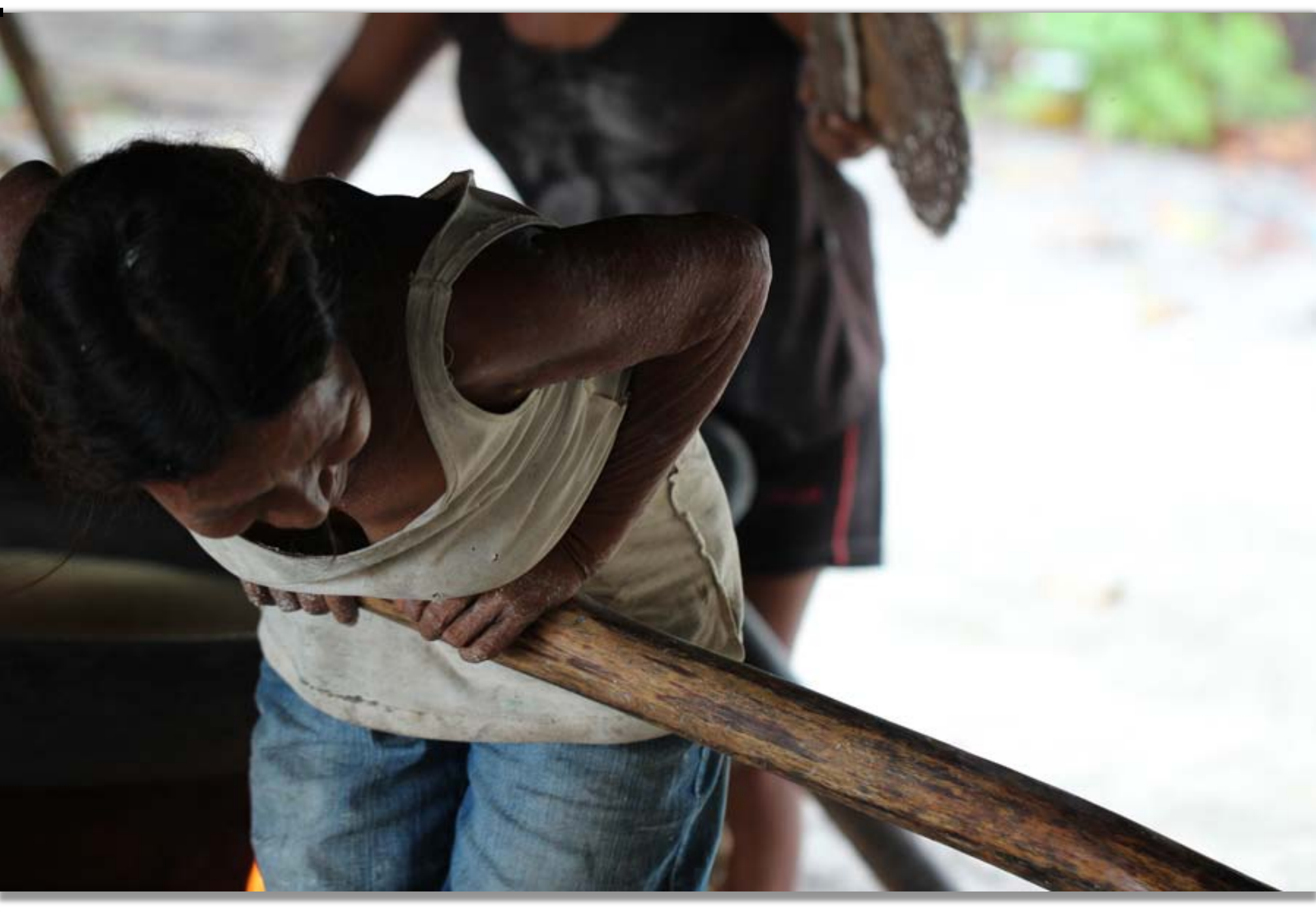




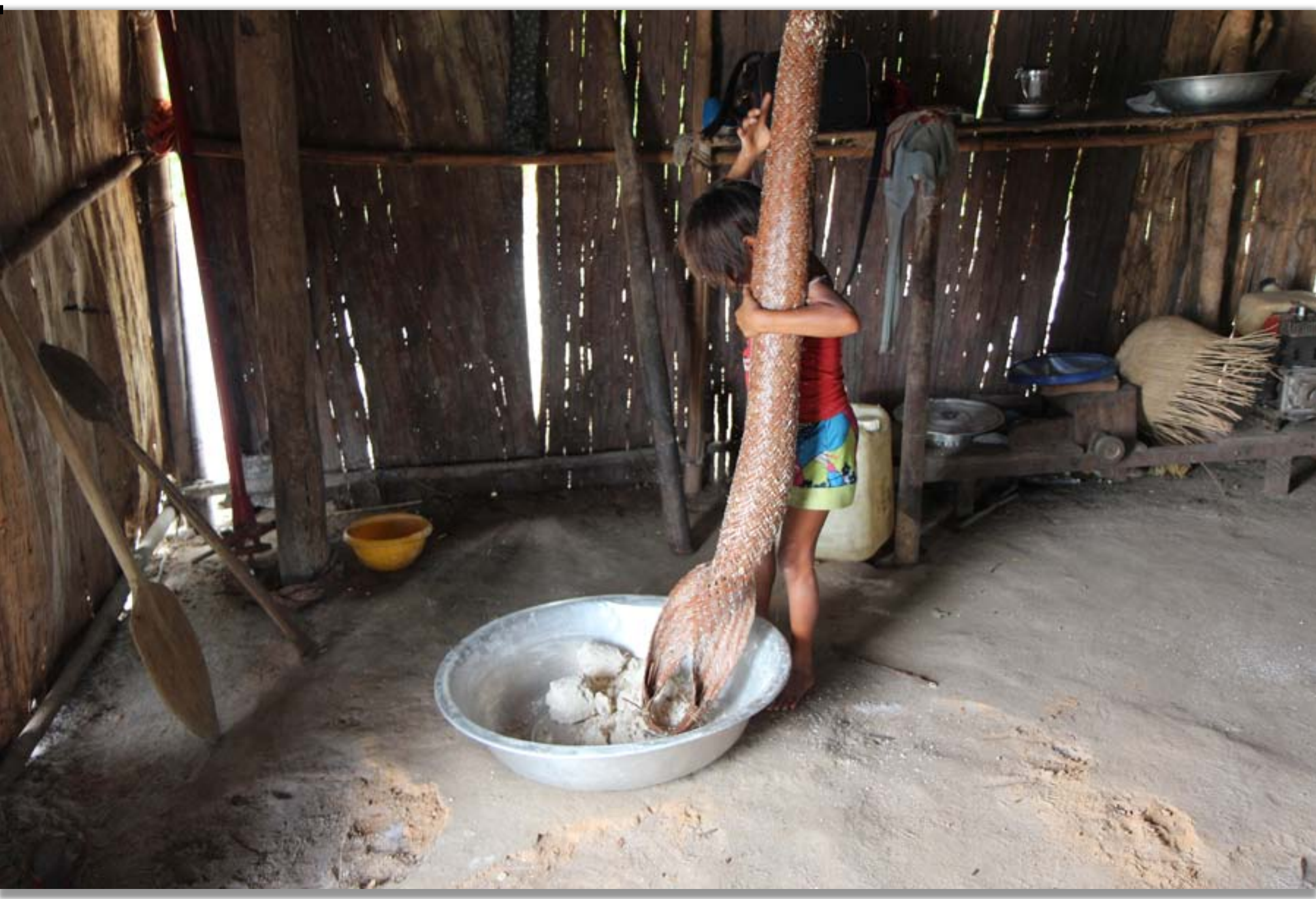




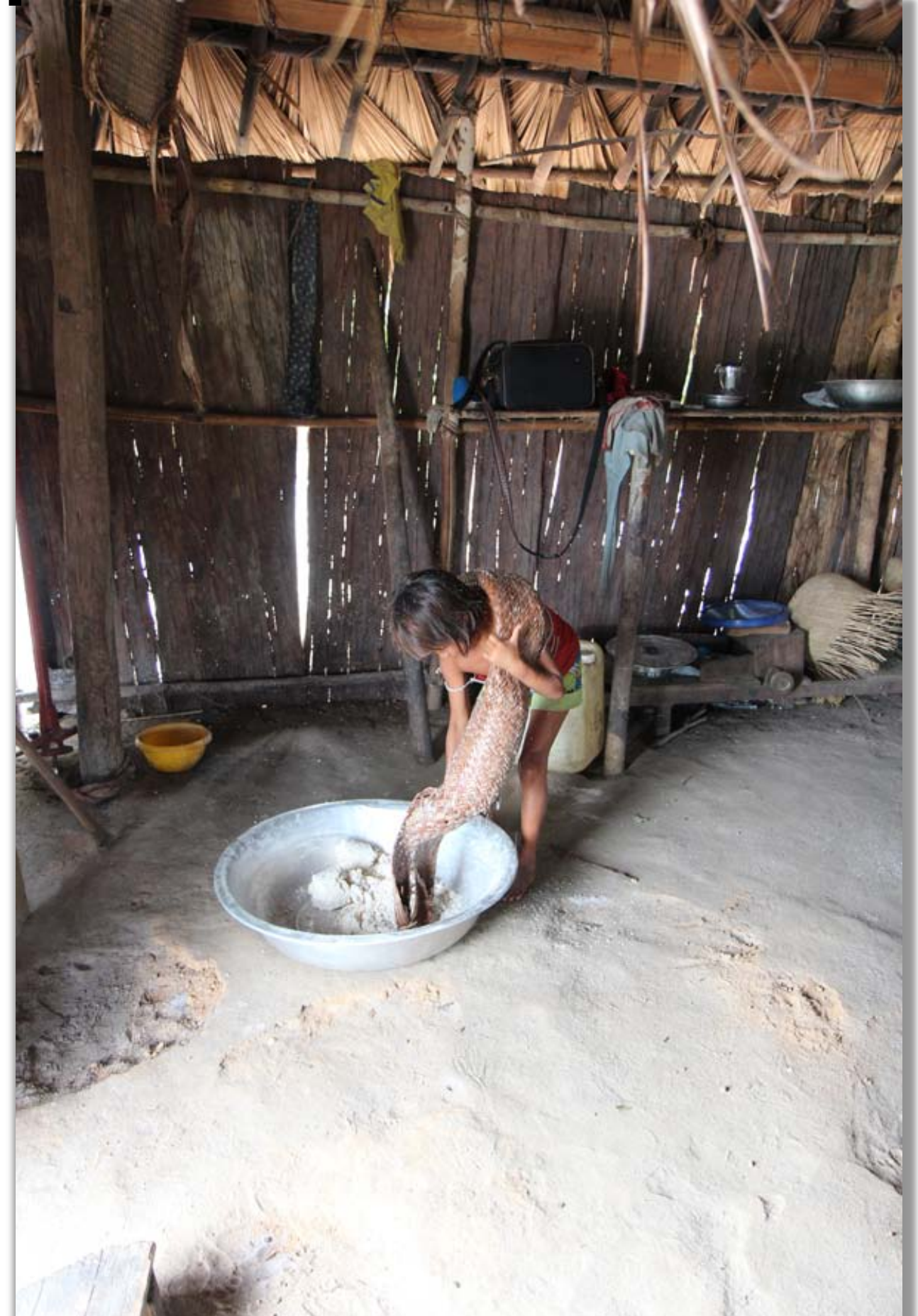




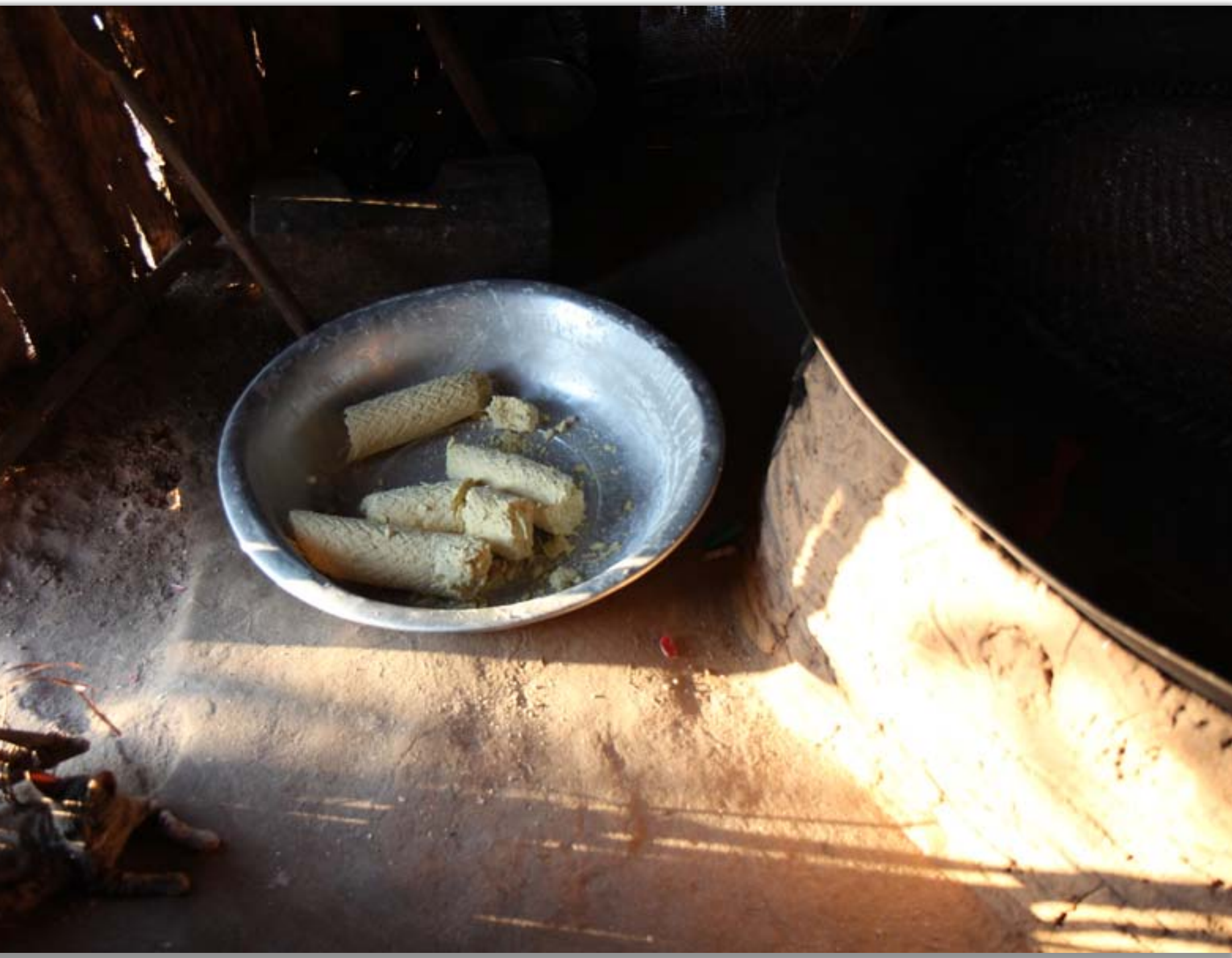

i

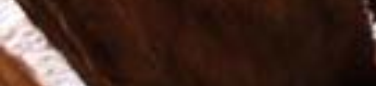

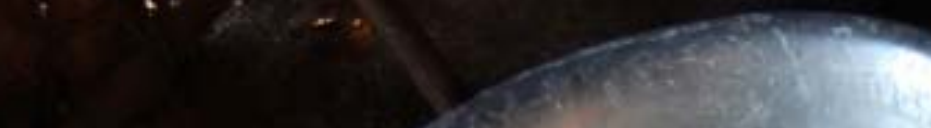

.

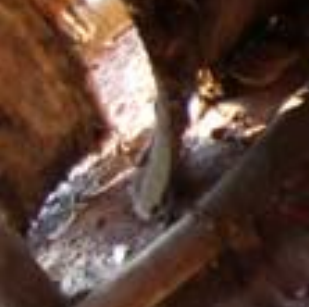

की

X.t.
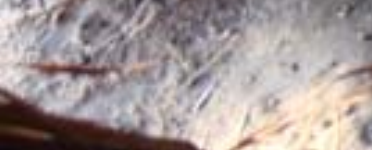

$a^{2}-\frac{1}{8}$

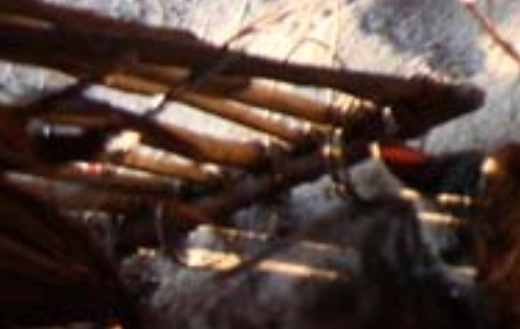

,.. 


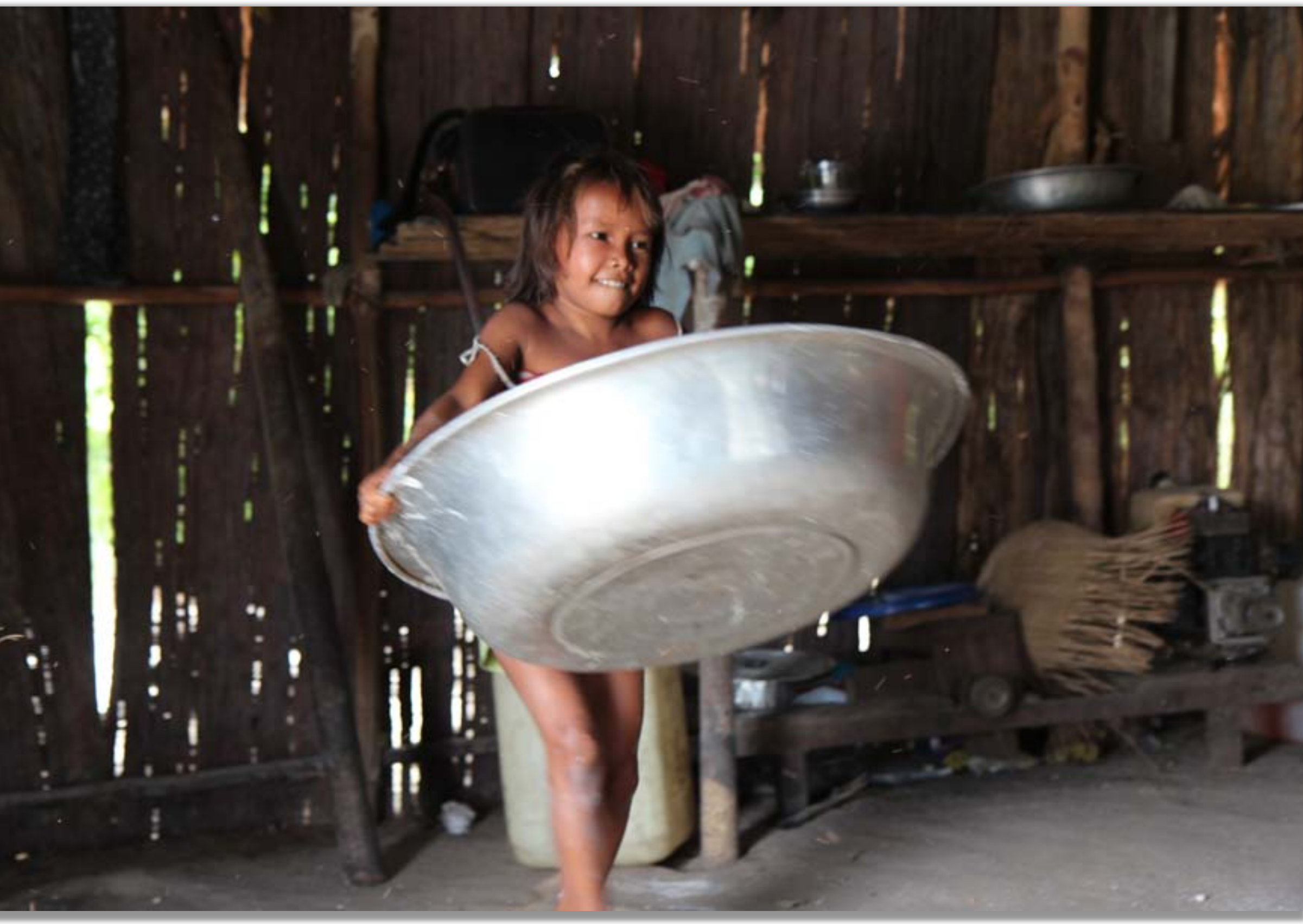




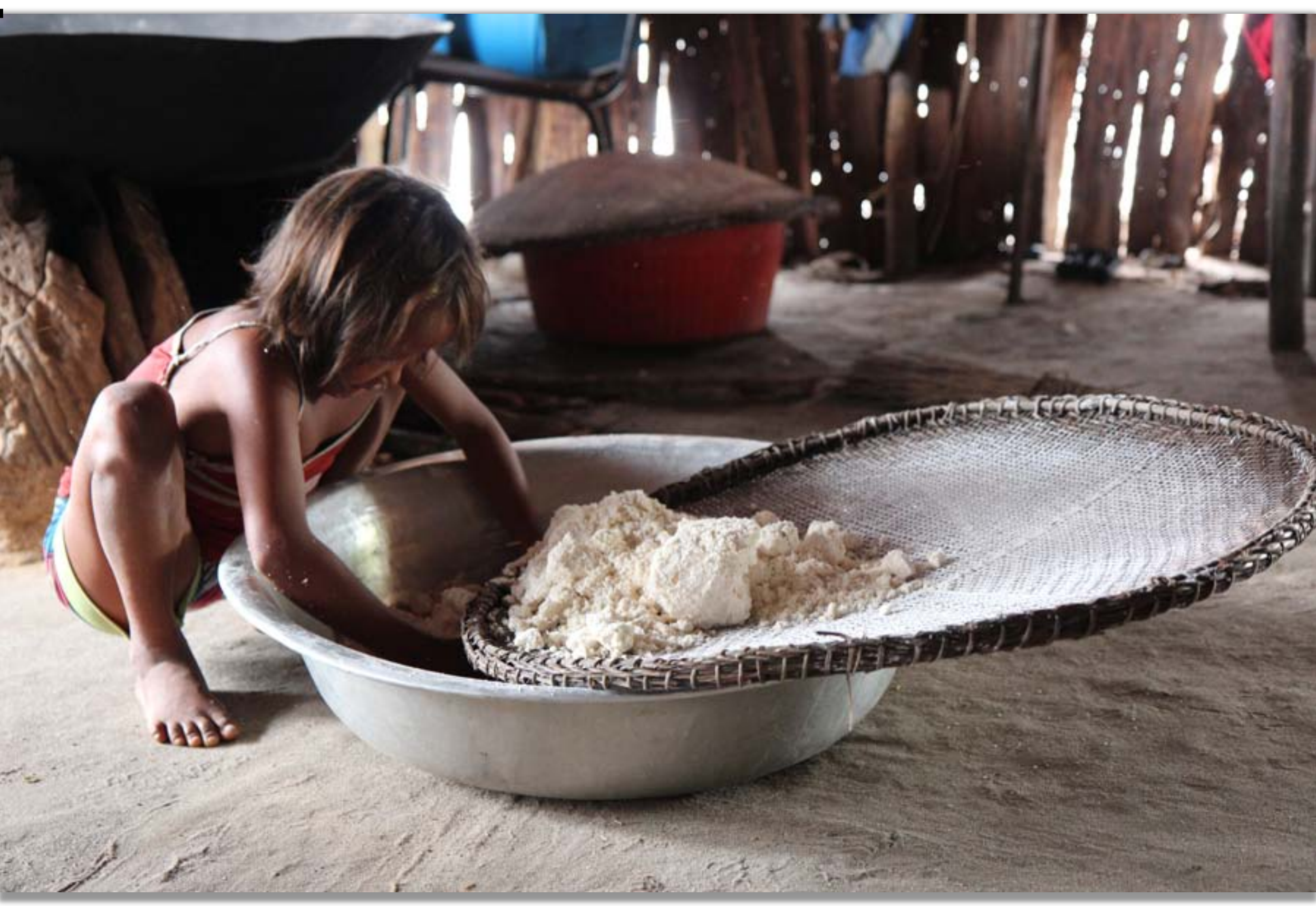




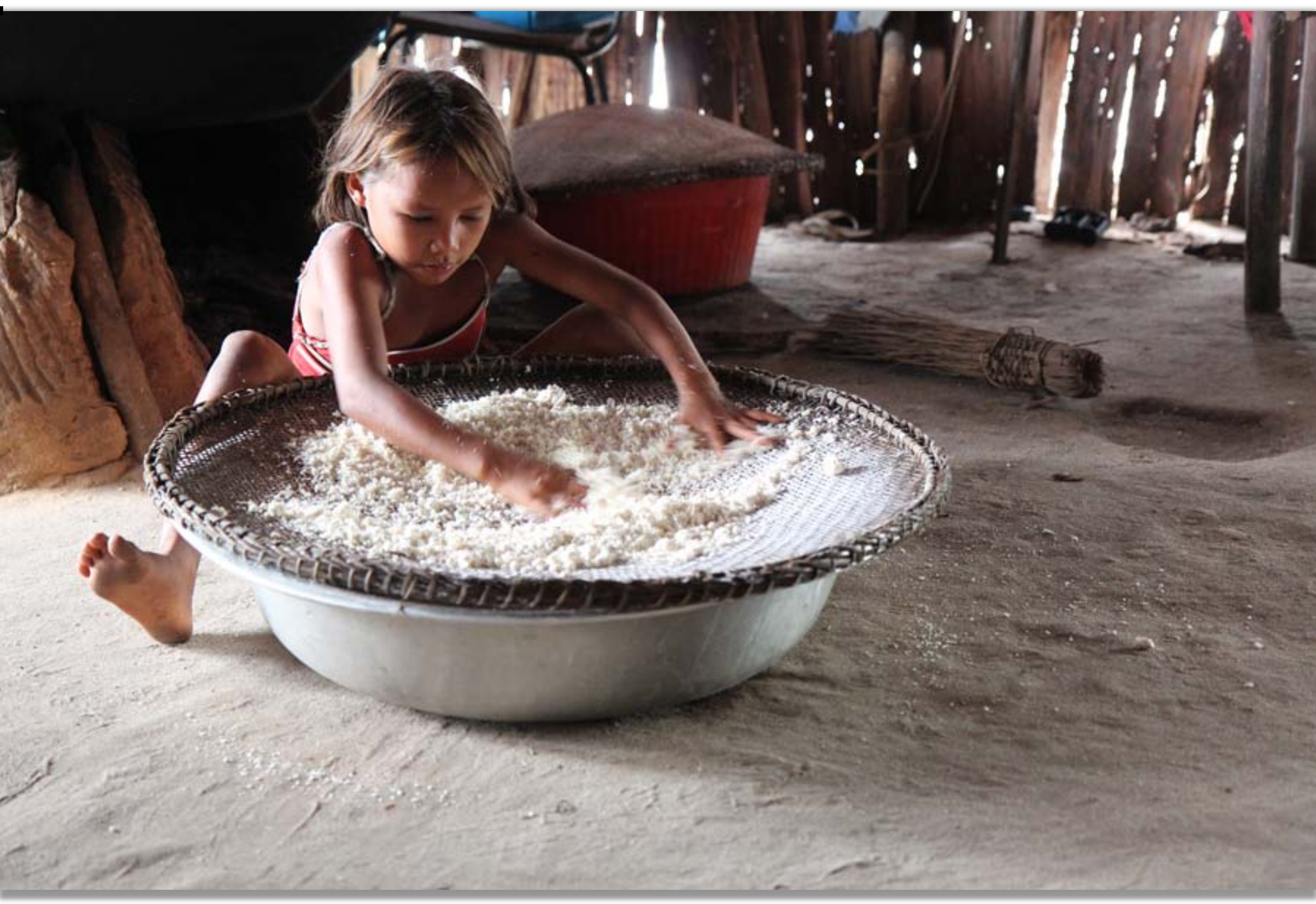




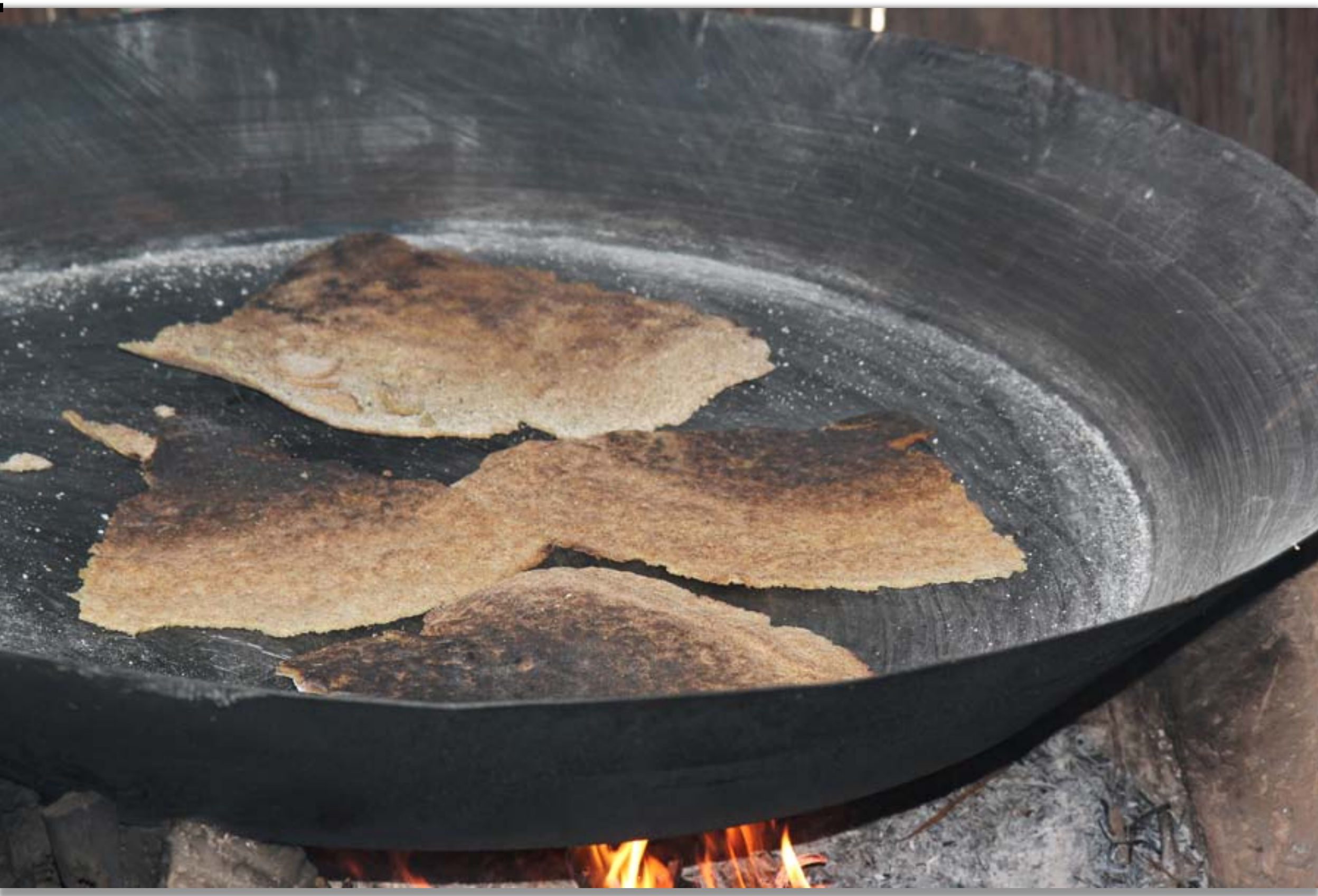

Toasted manioc to make caxiri 


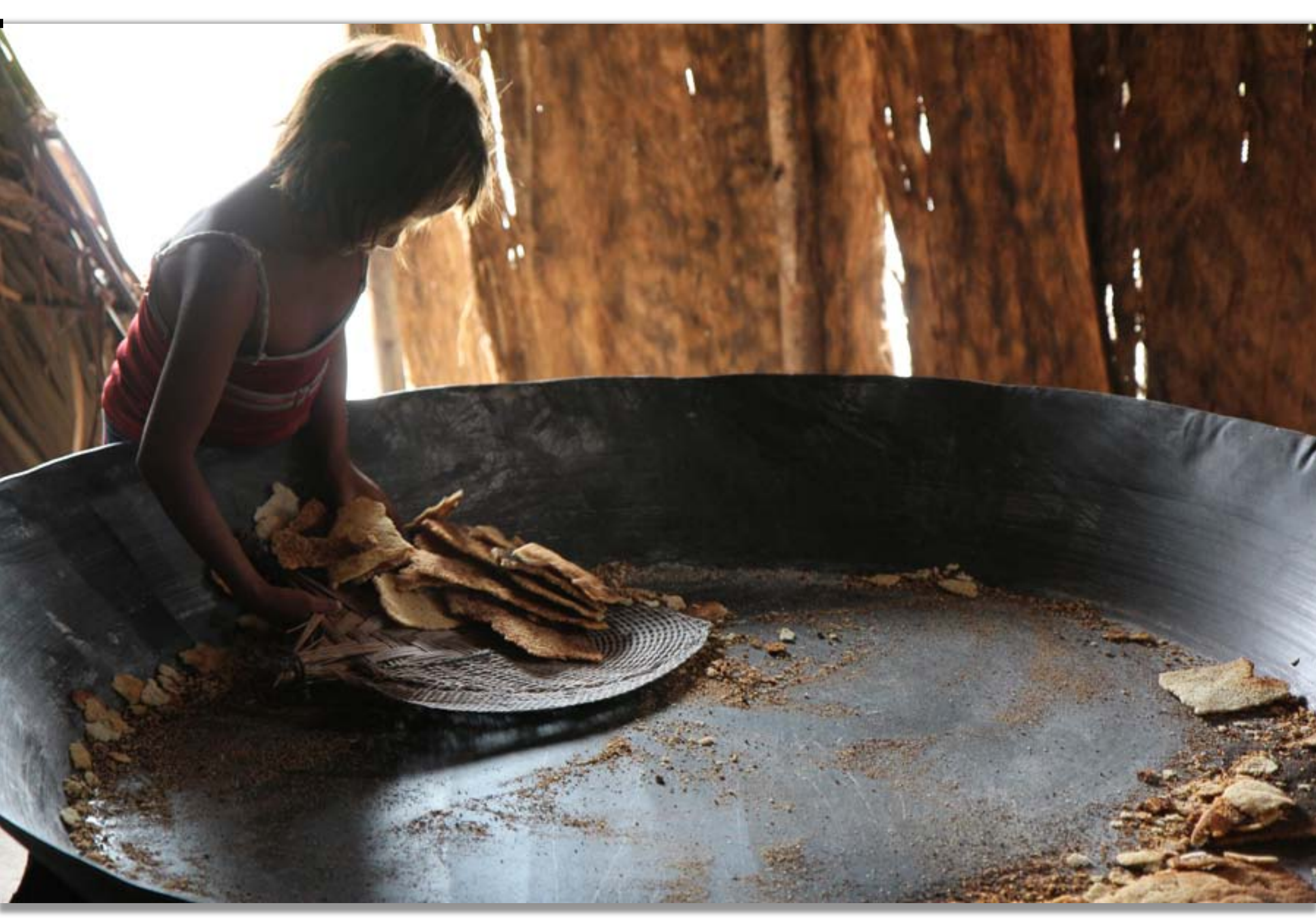




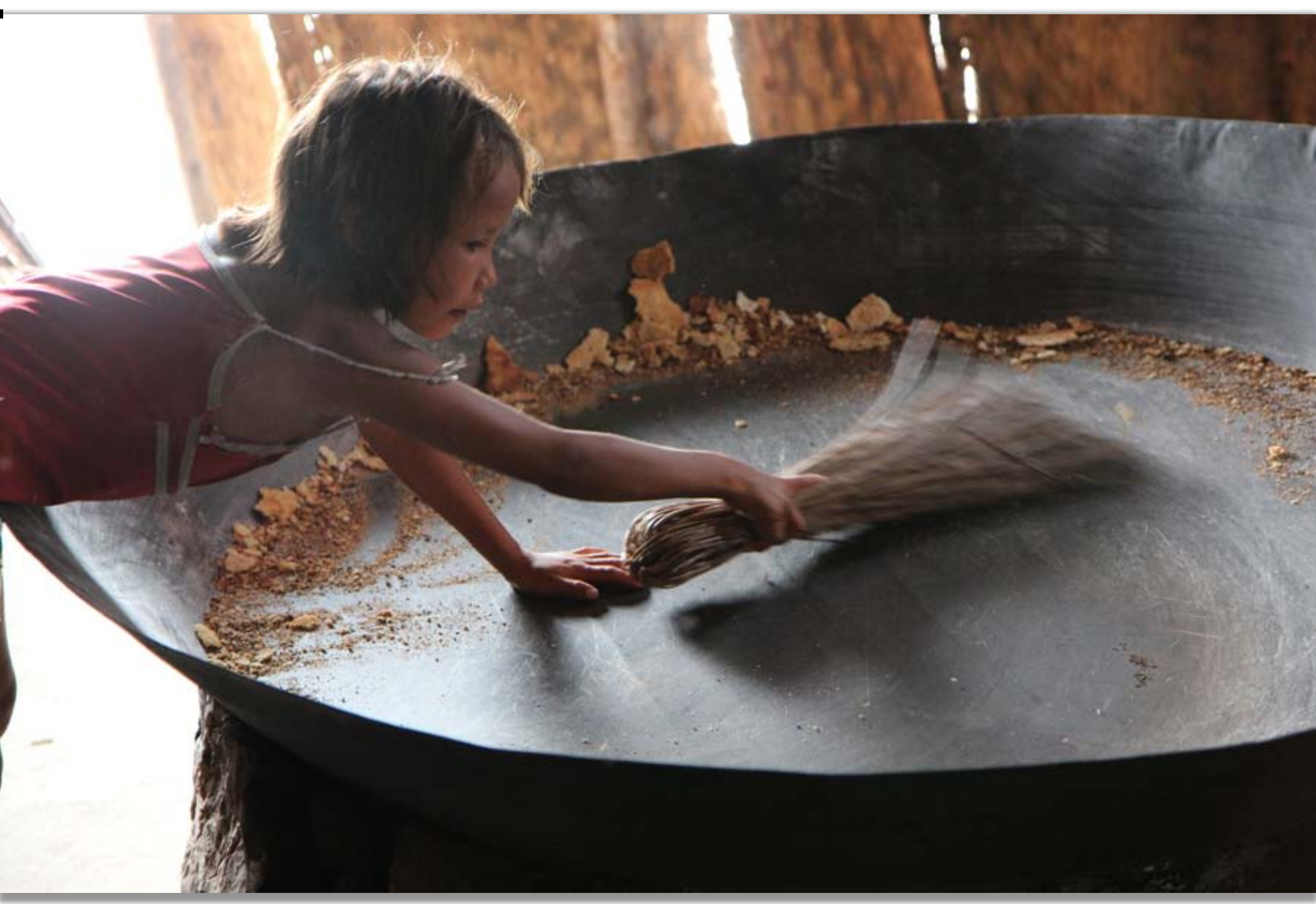




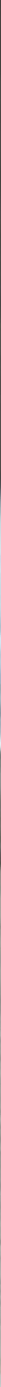

Trough to ferment caxiri 


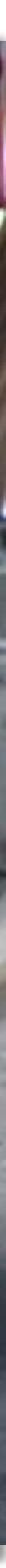




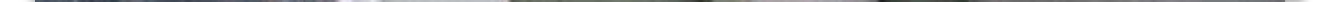




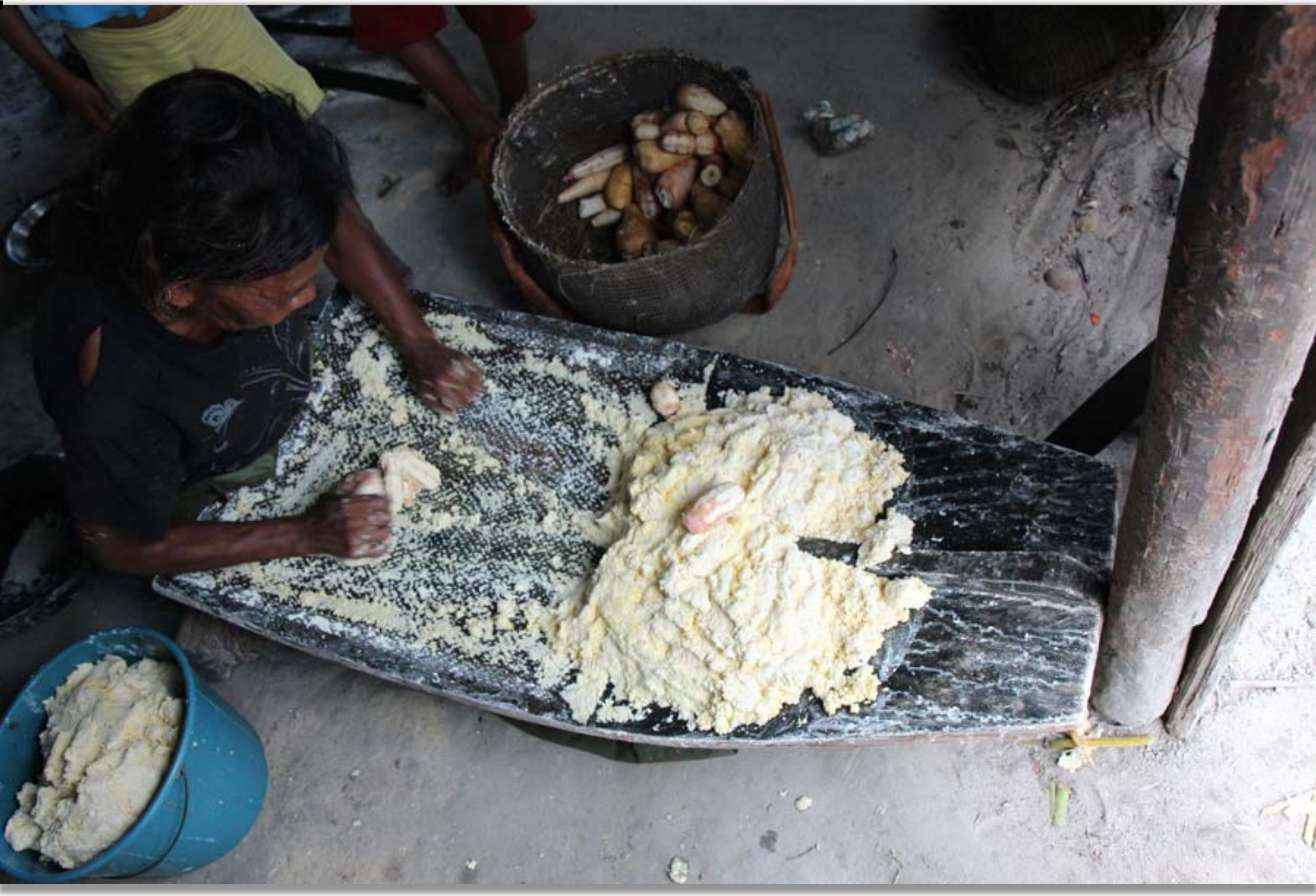

Manioc may be grated in different ways 


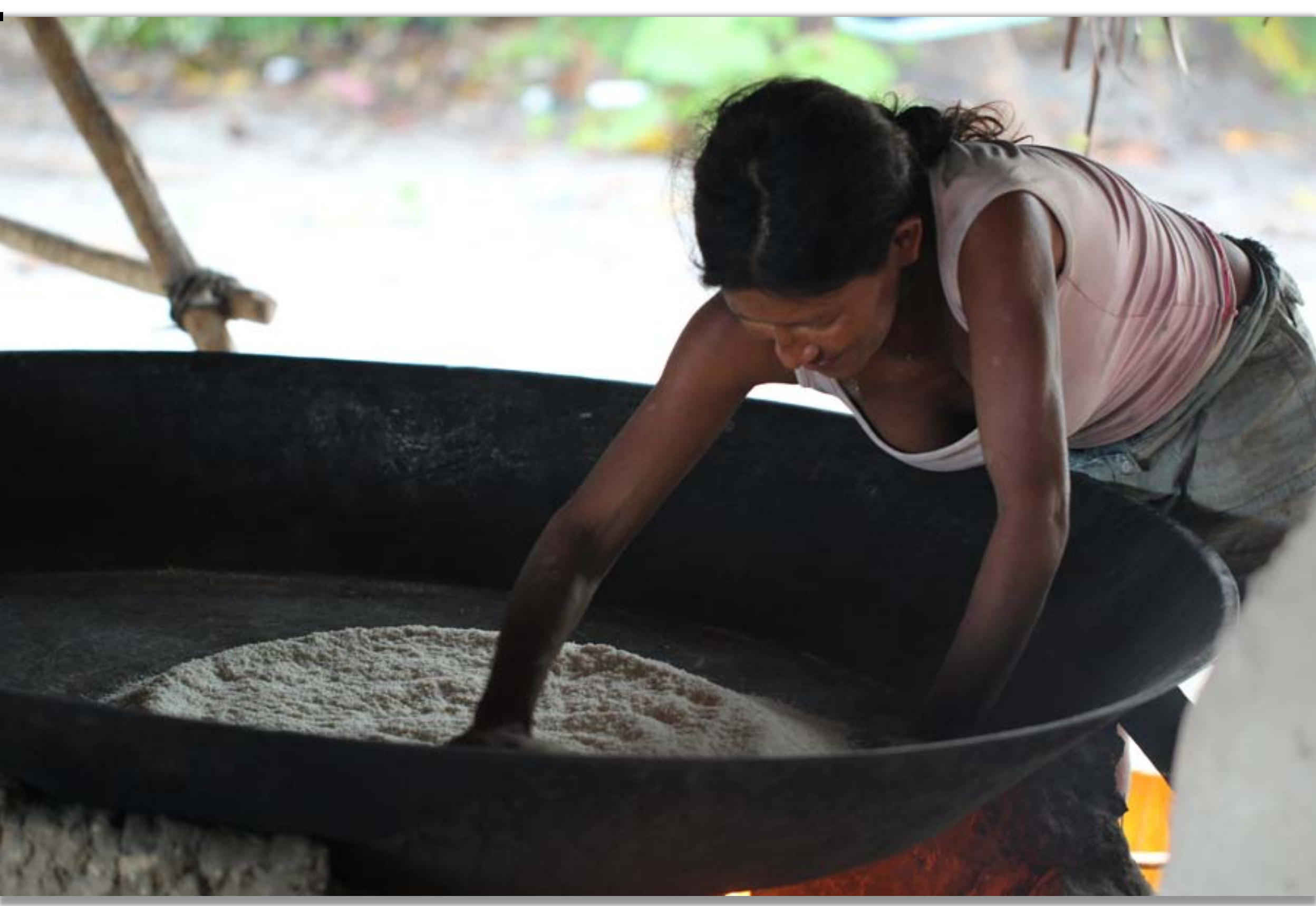




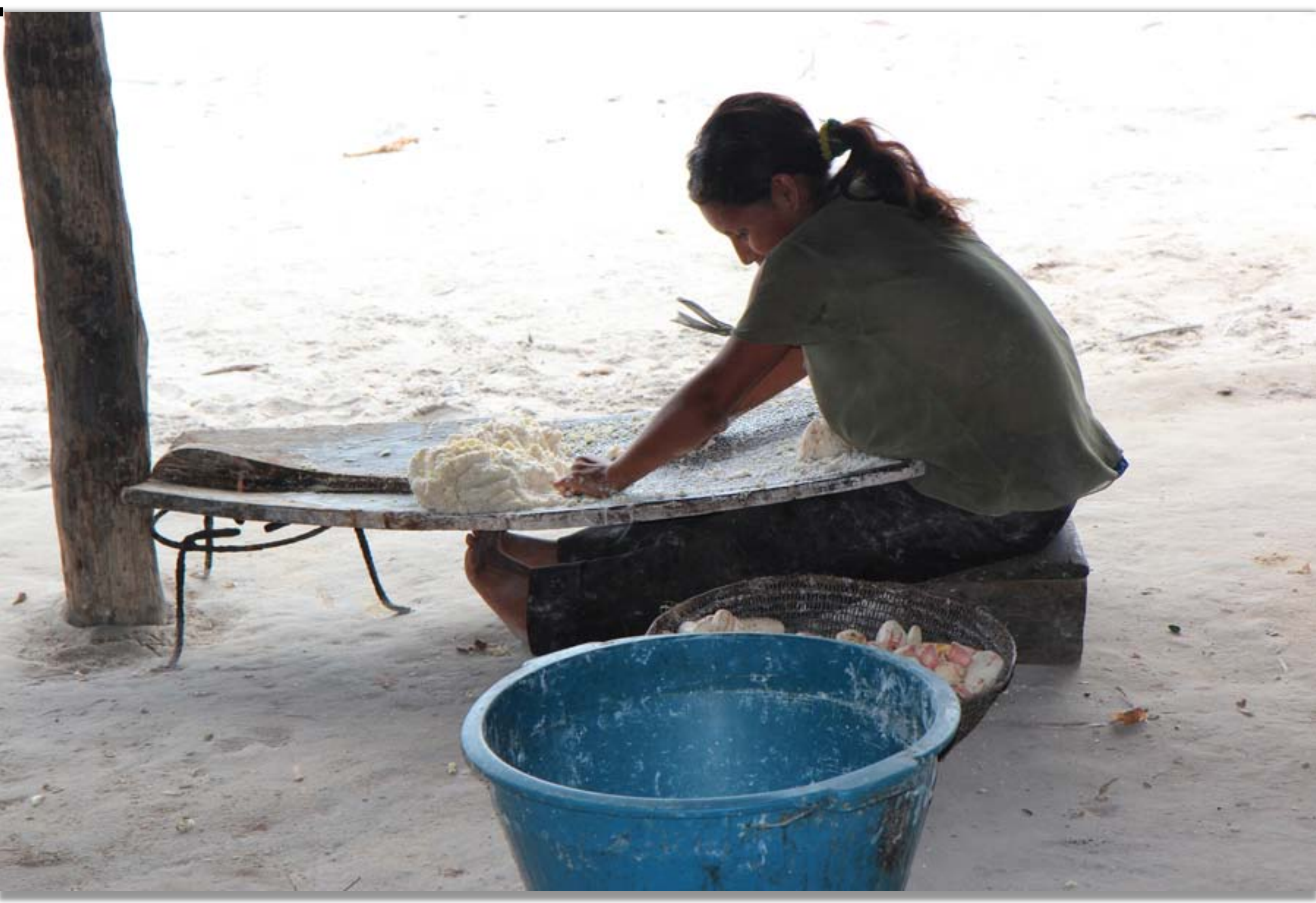




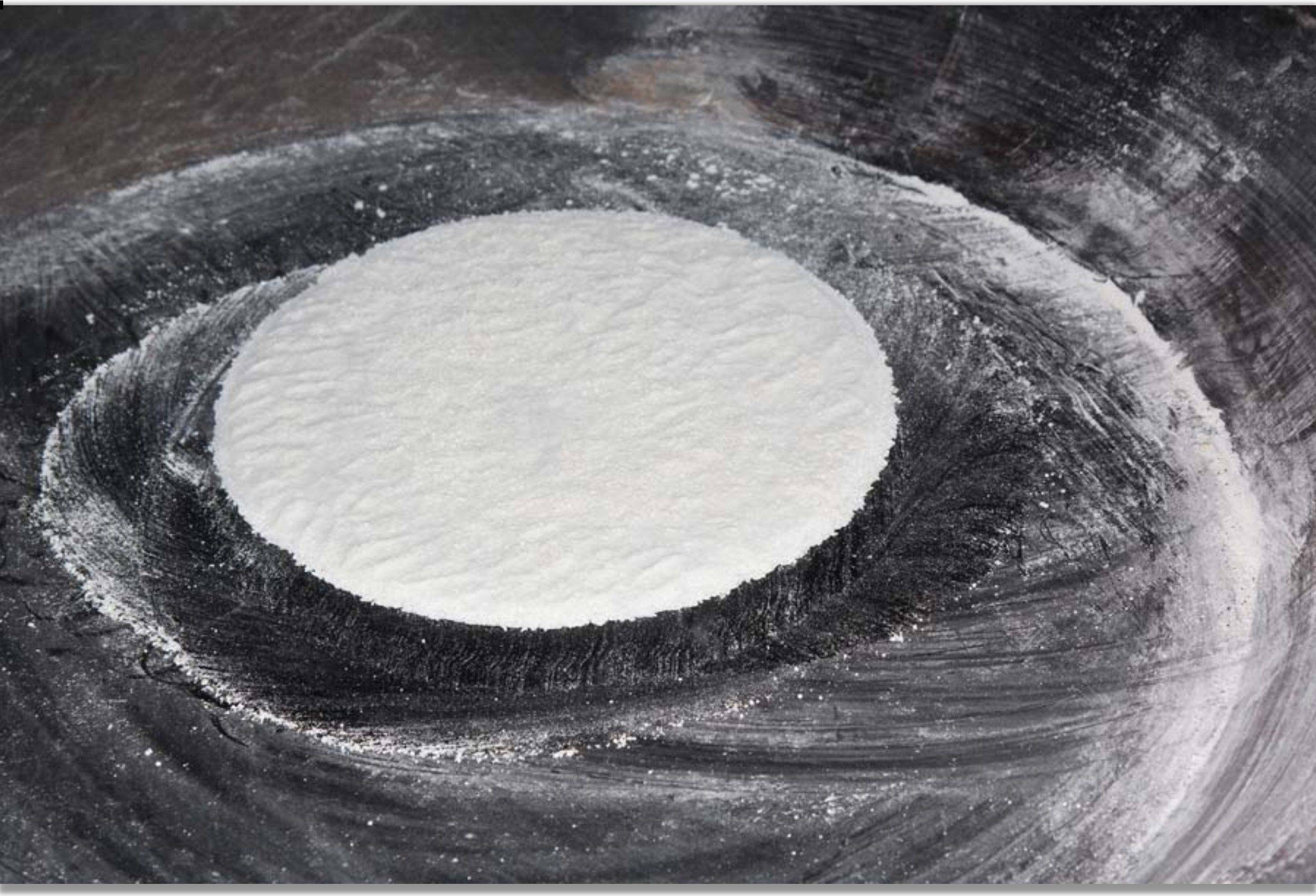




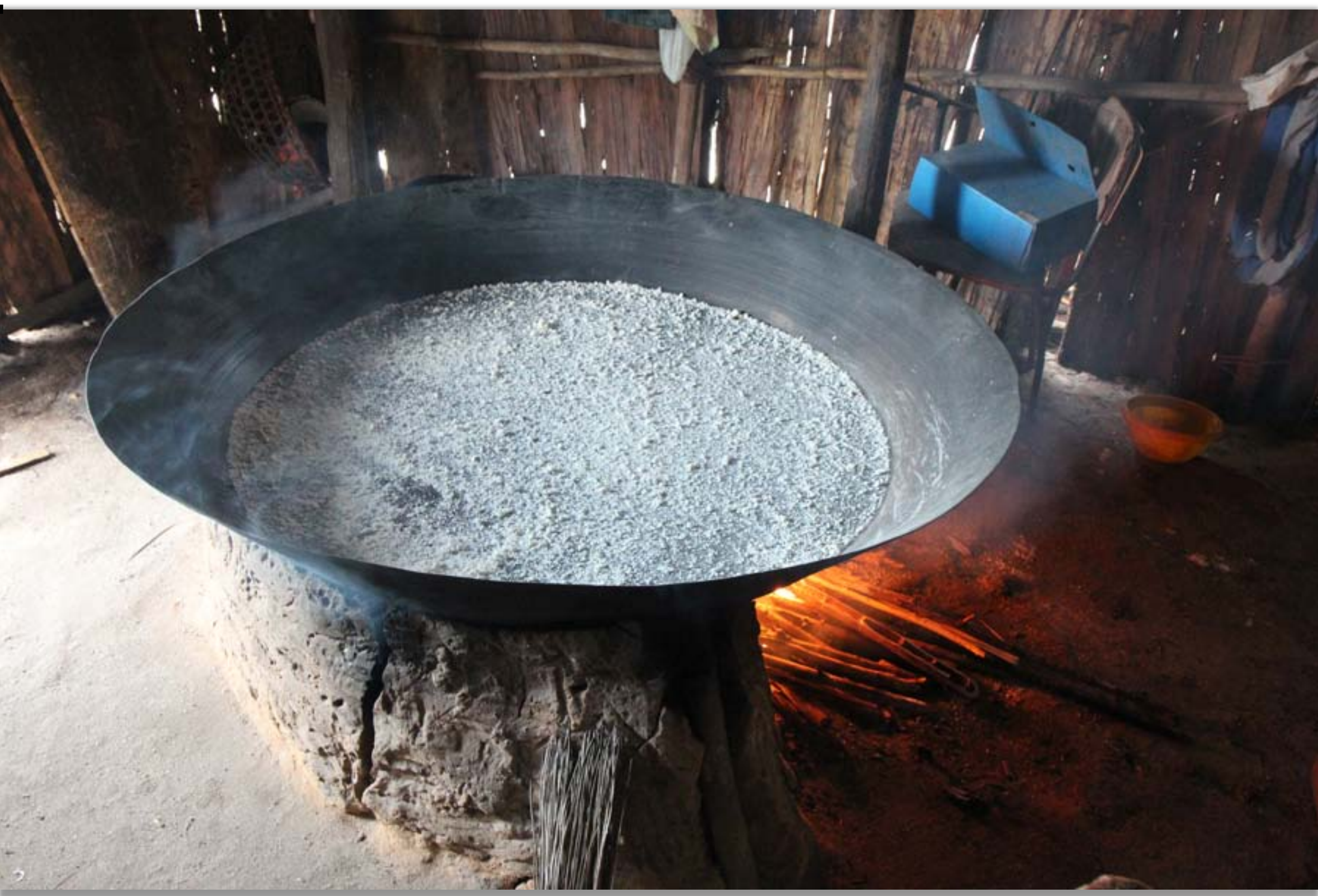

Beiju, the manioc bread 


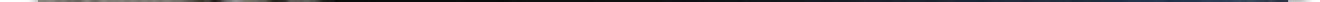




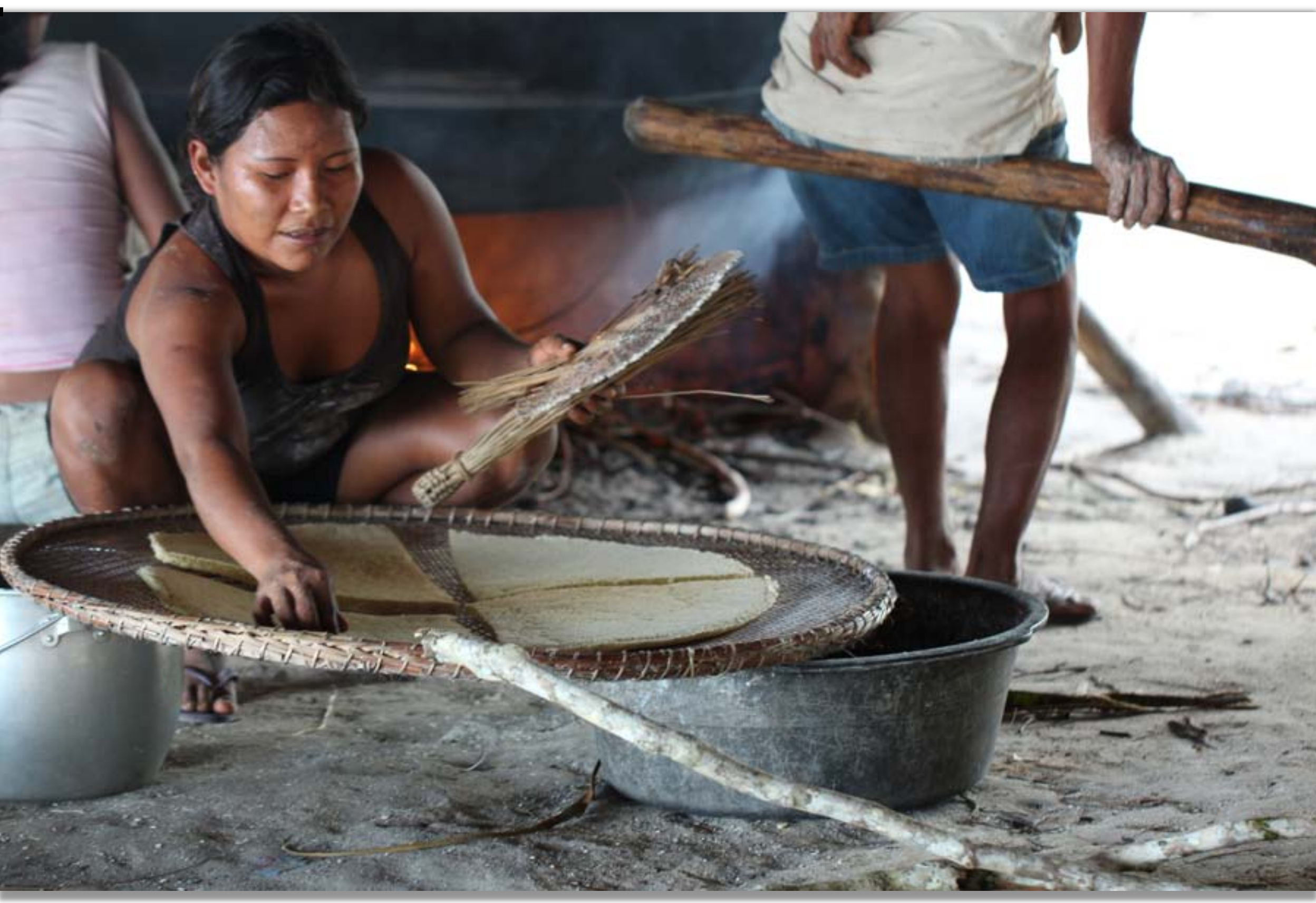

Divided in 4 slices, beiju cools in a straw sieve 


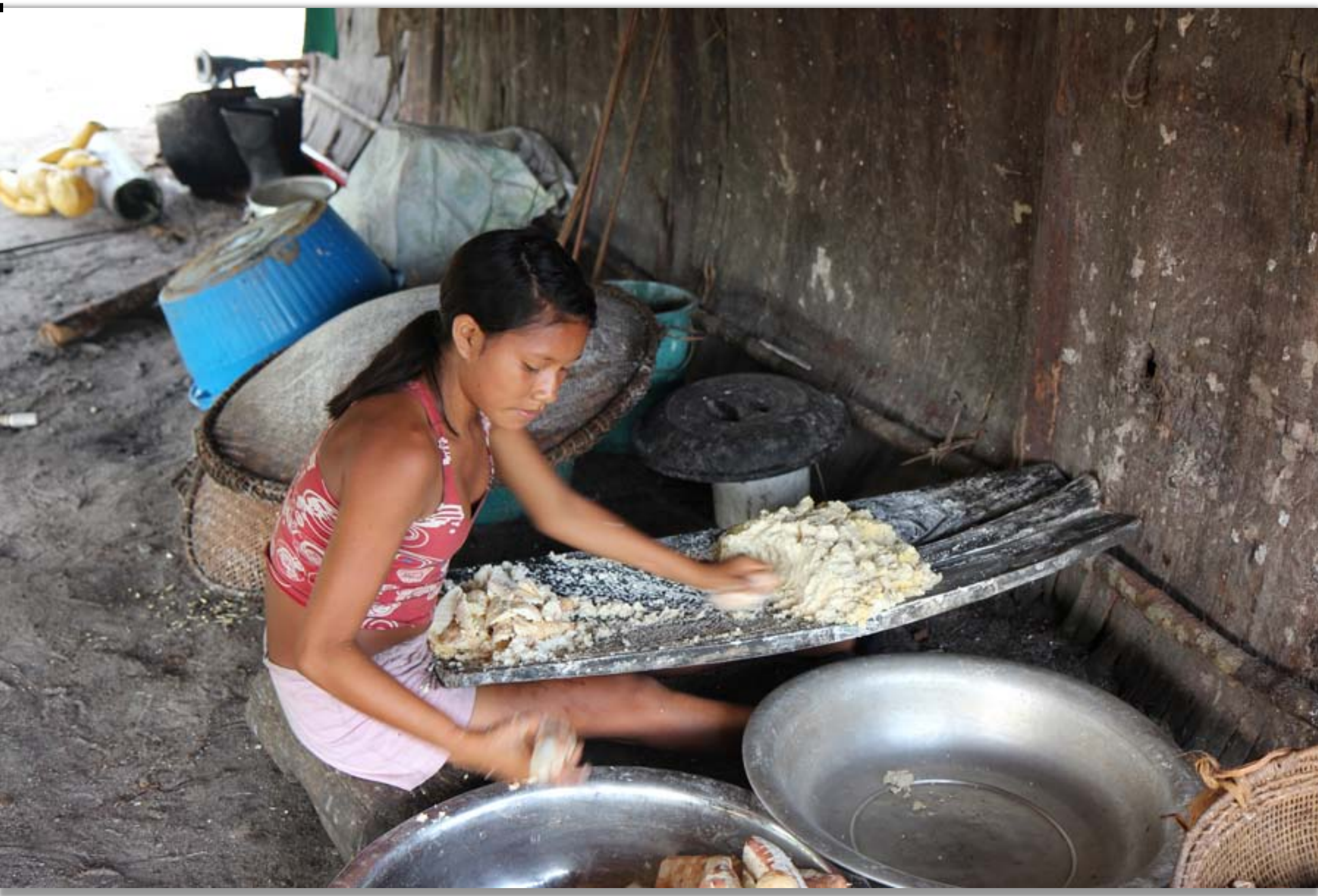

With the yellow manioc they make a delicious flour 


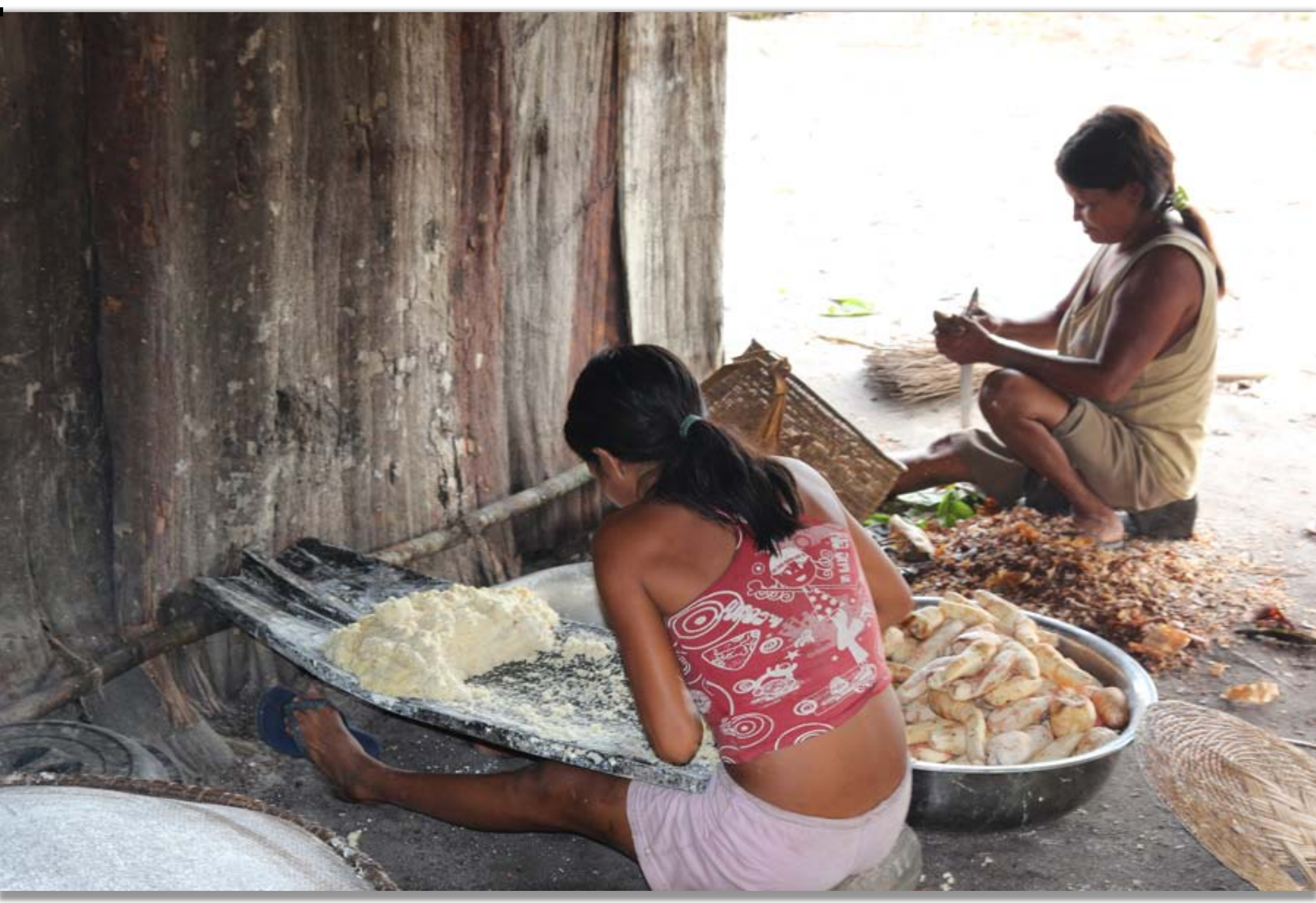




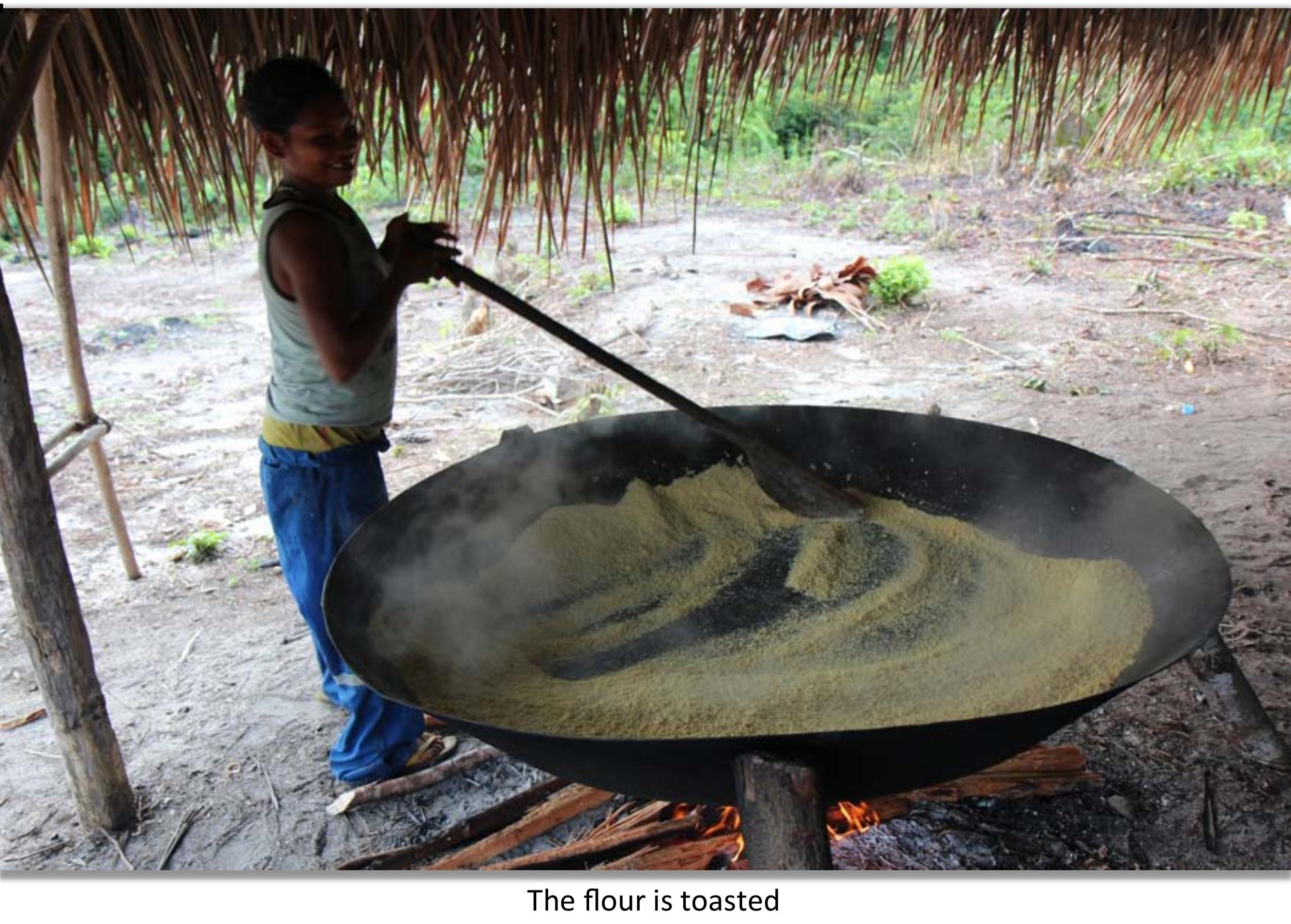




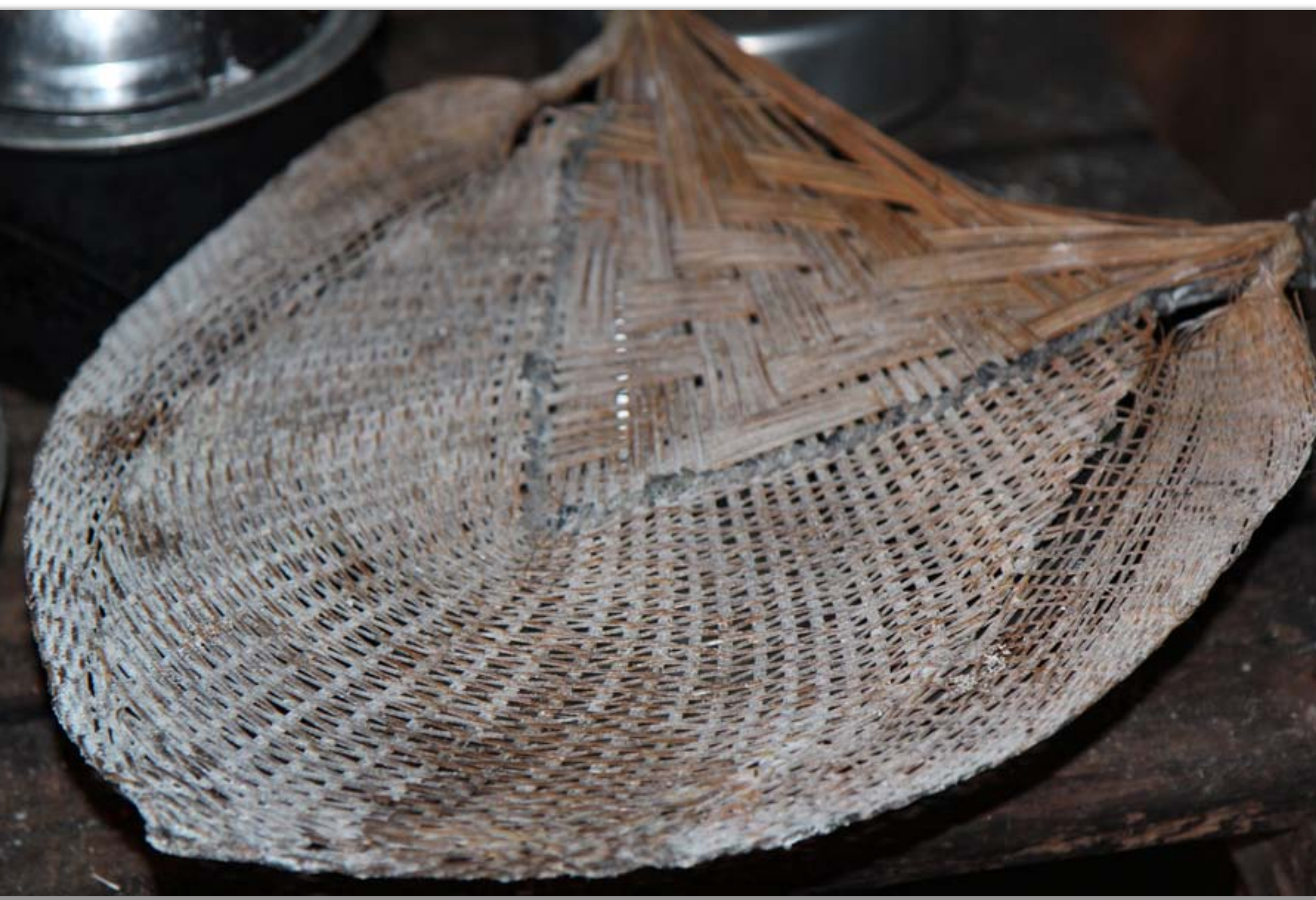

Fans, made of straw, are used to fan the fire and lift the beiju from the pan 
CHILDREN'S PLAY

CHILDREN'S PLAY 


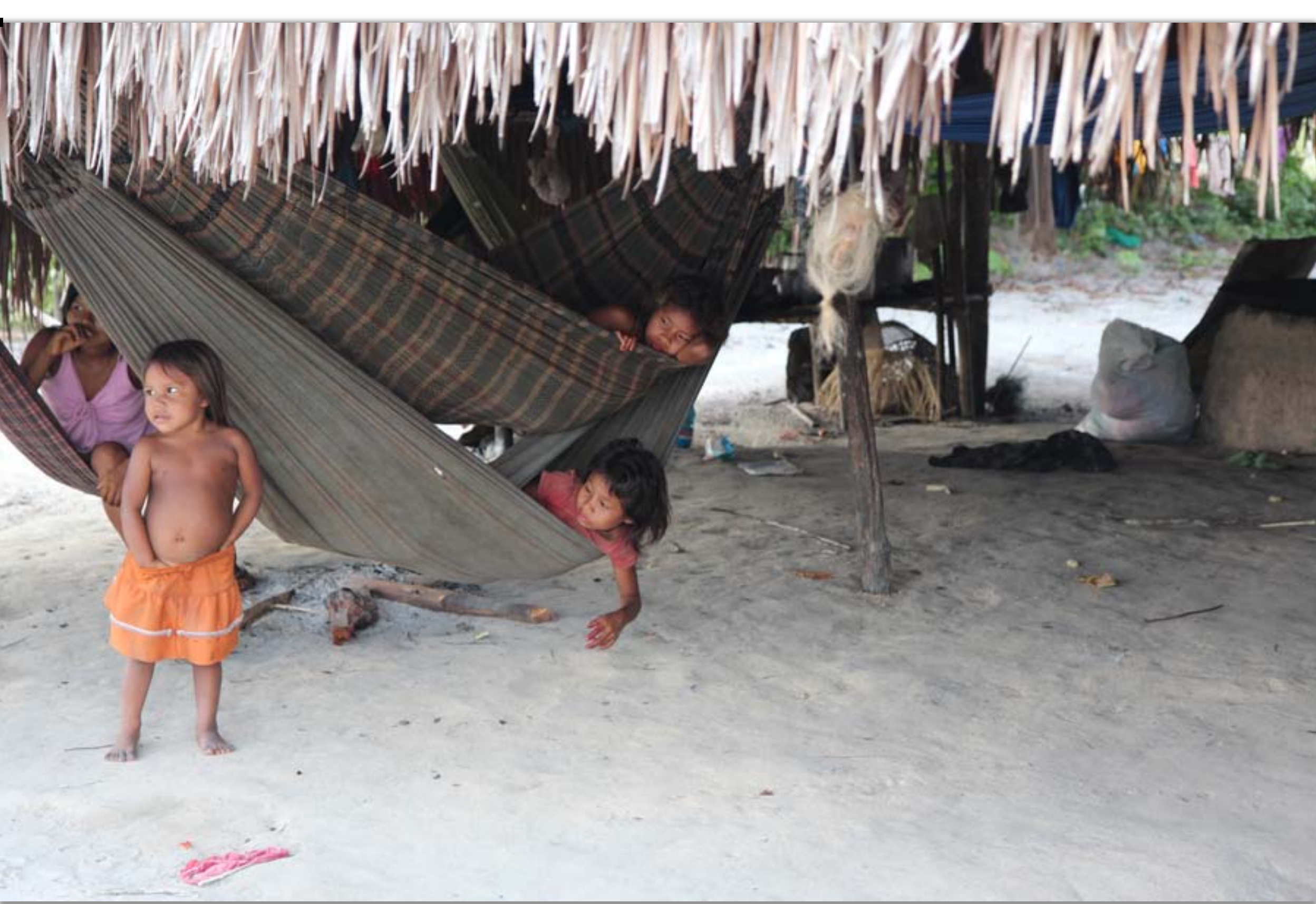




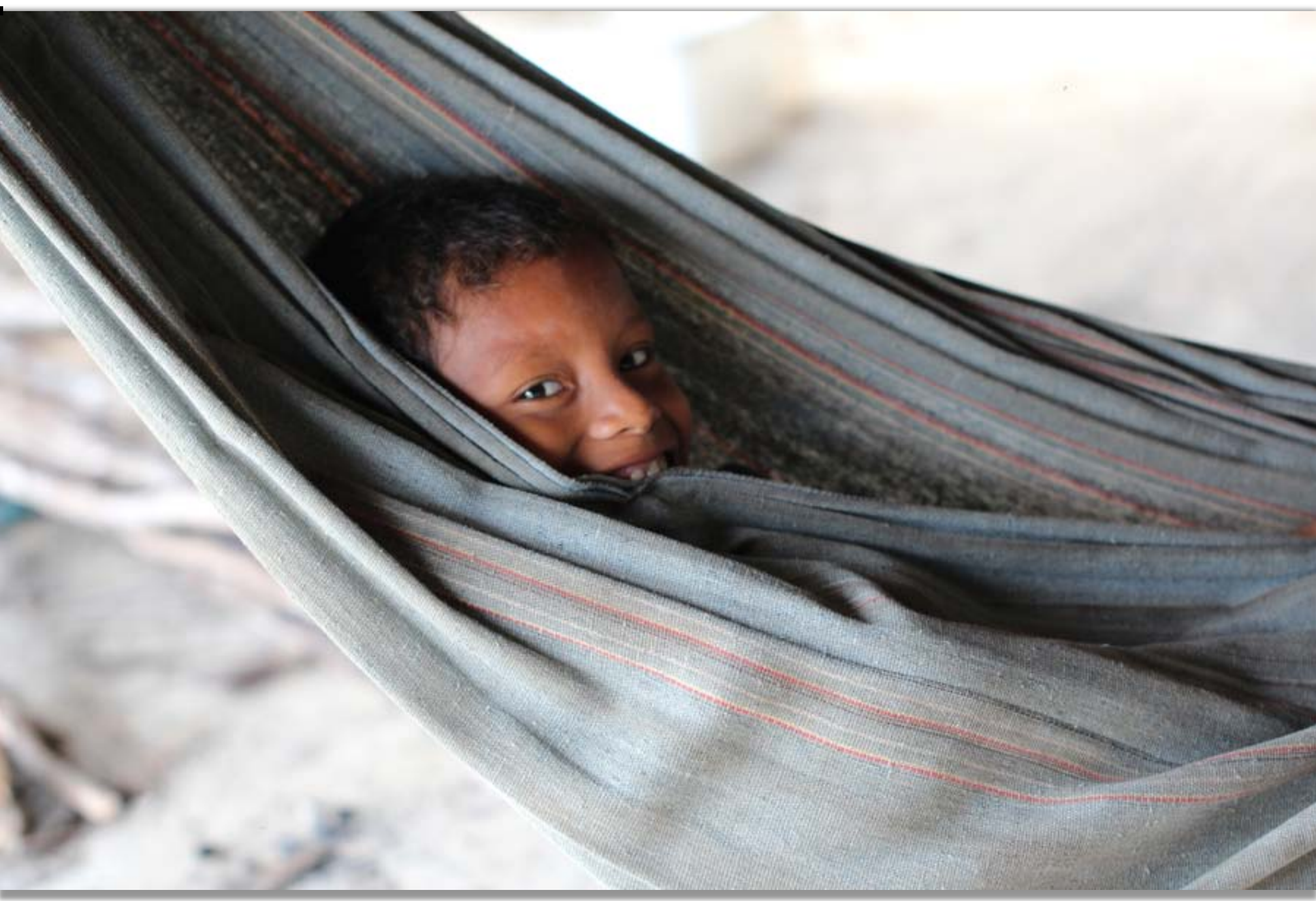




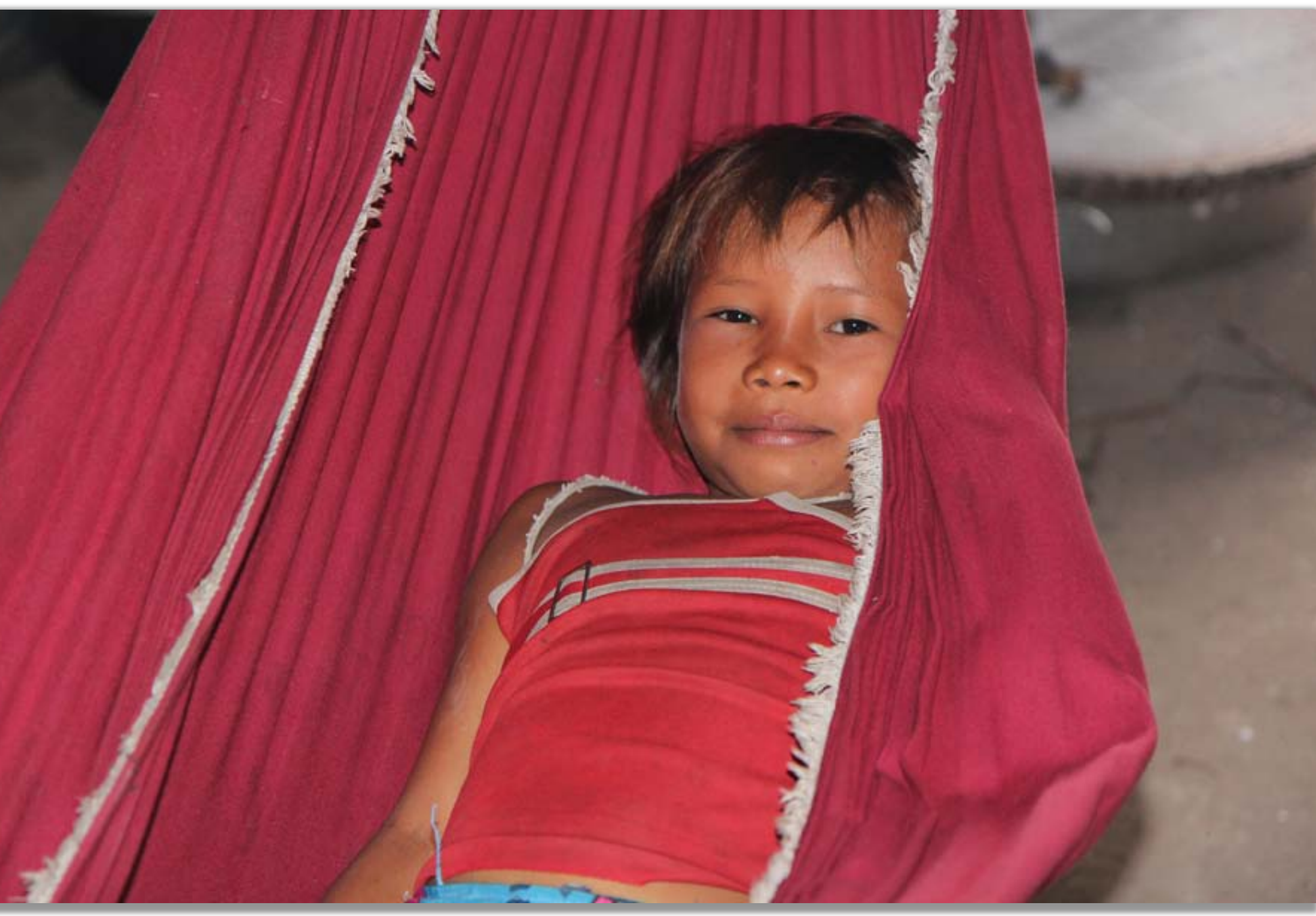


$11: 1$

1

i.

11.

1.

1

1 


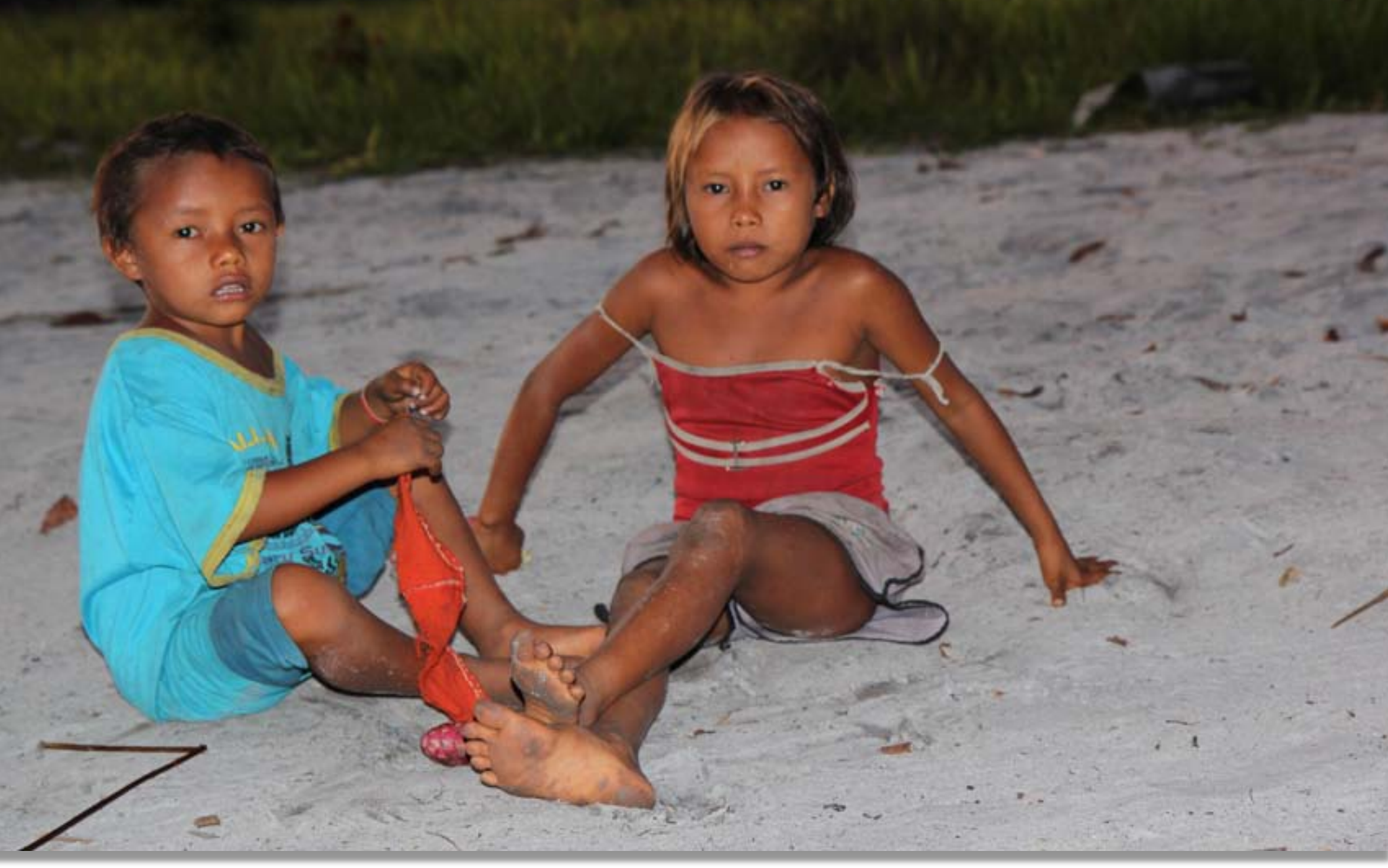




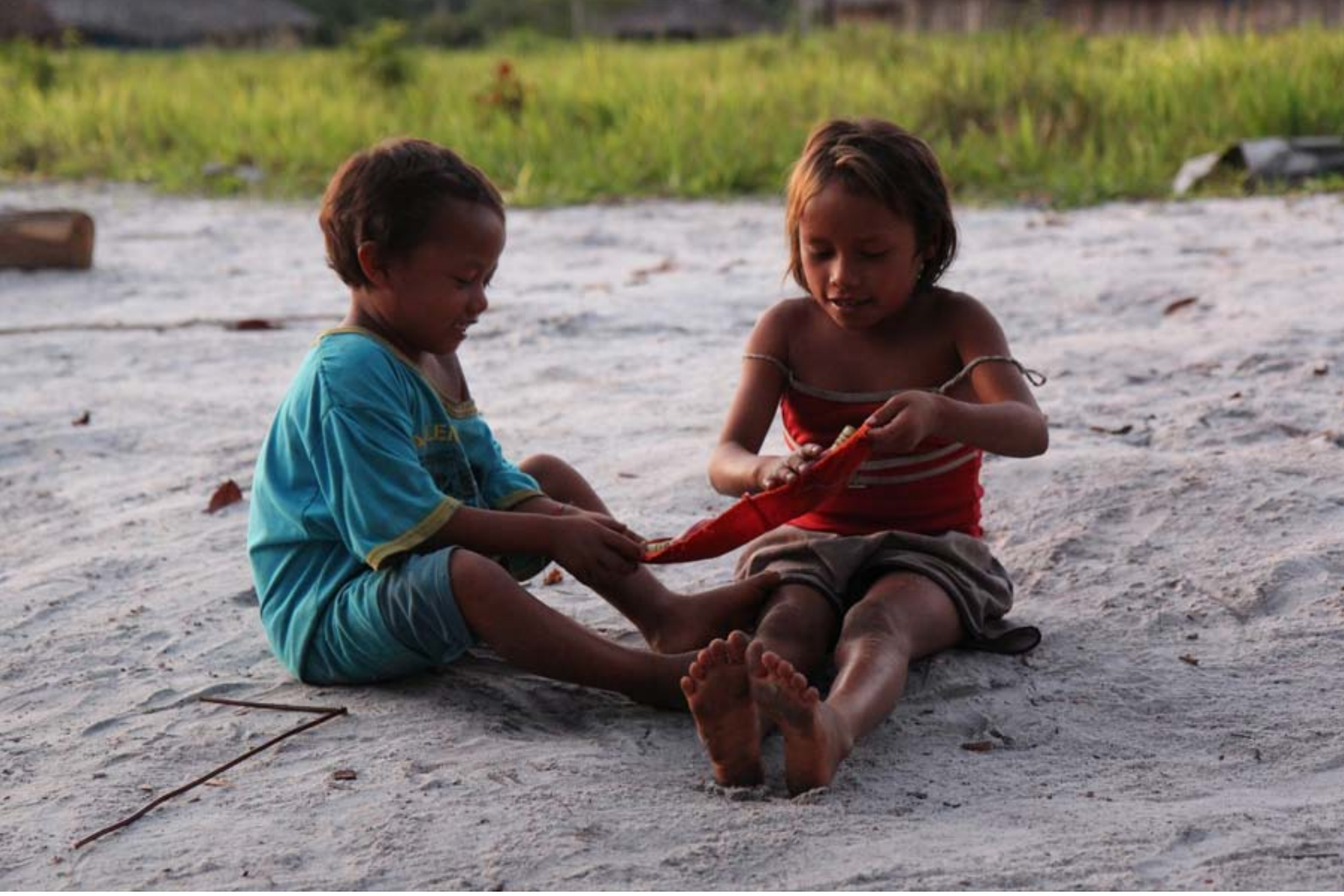




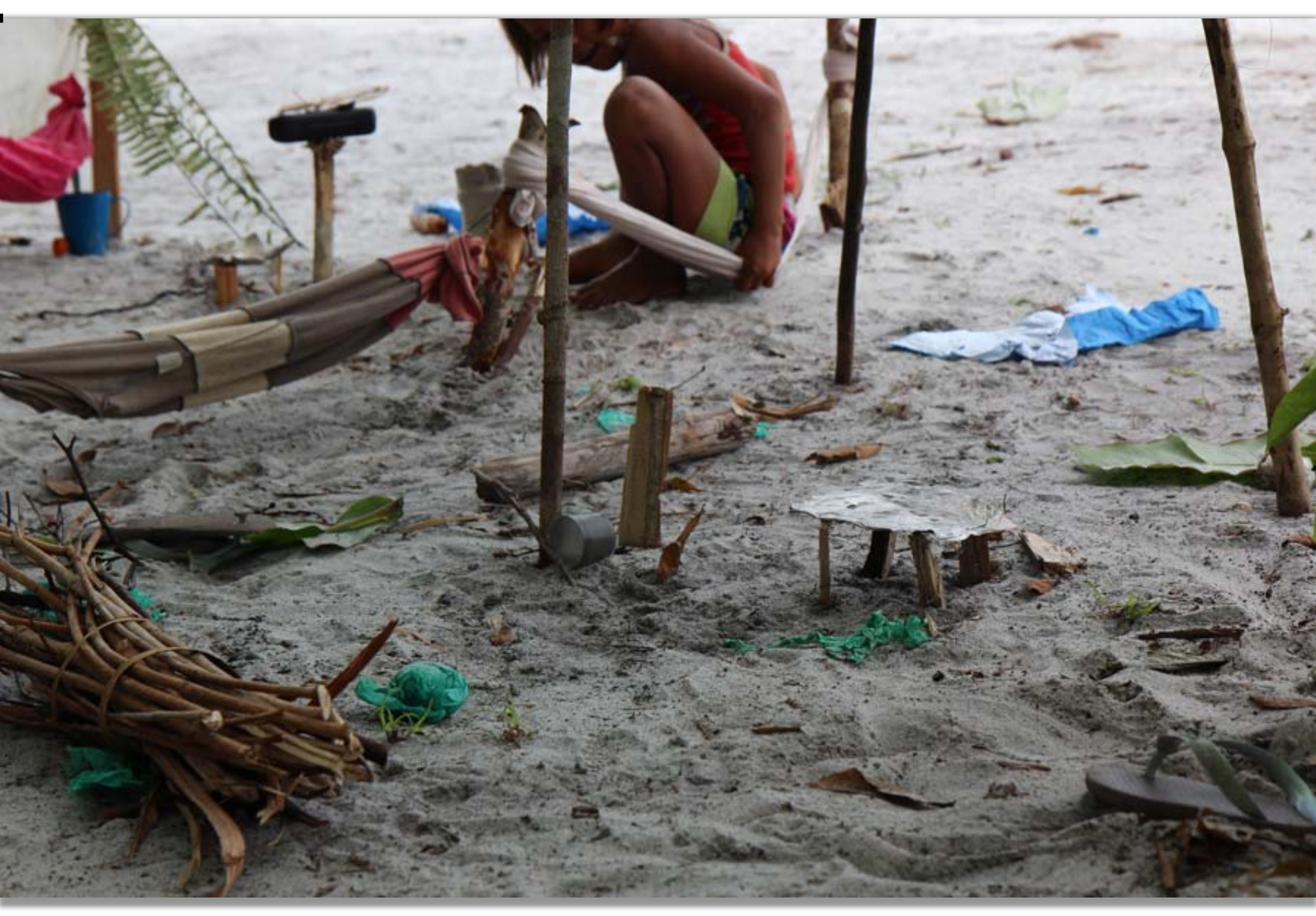




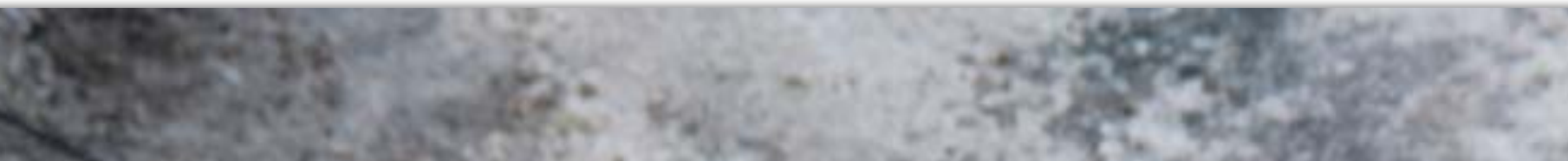

Thes ar the

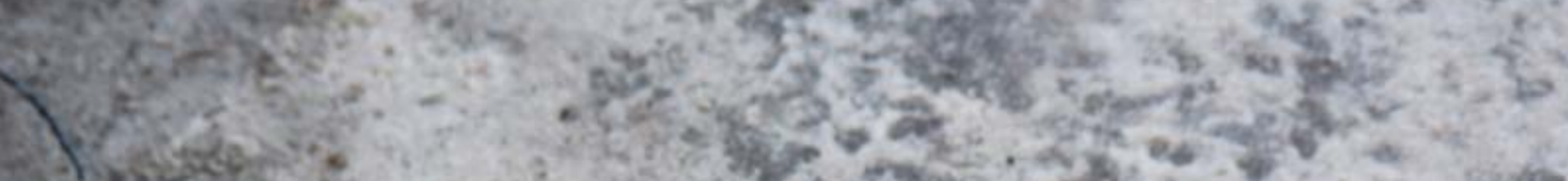

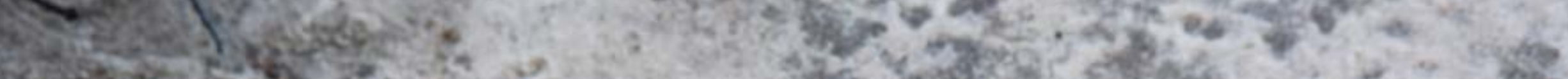

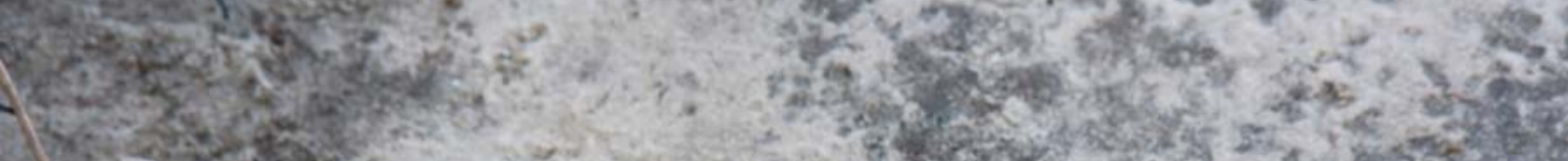

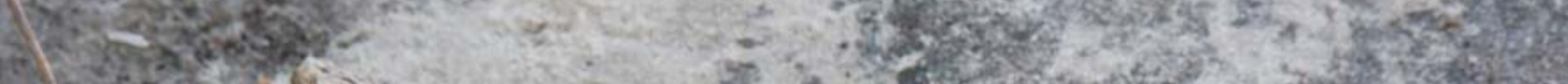
S.

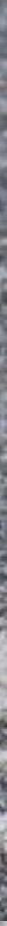




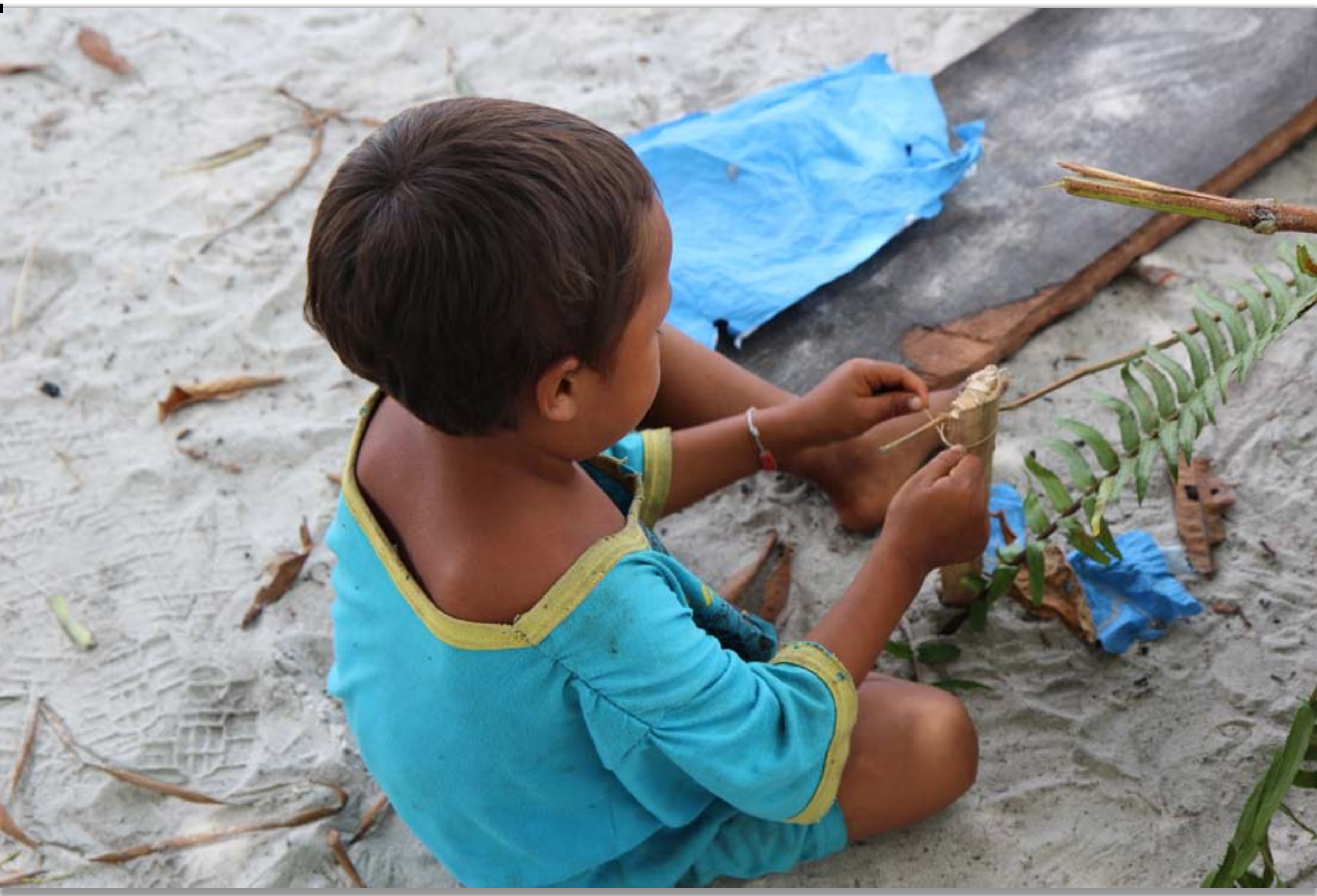




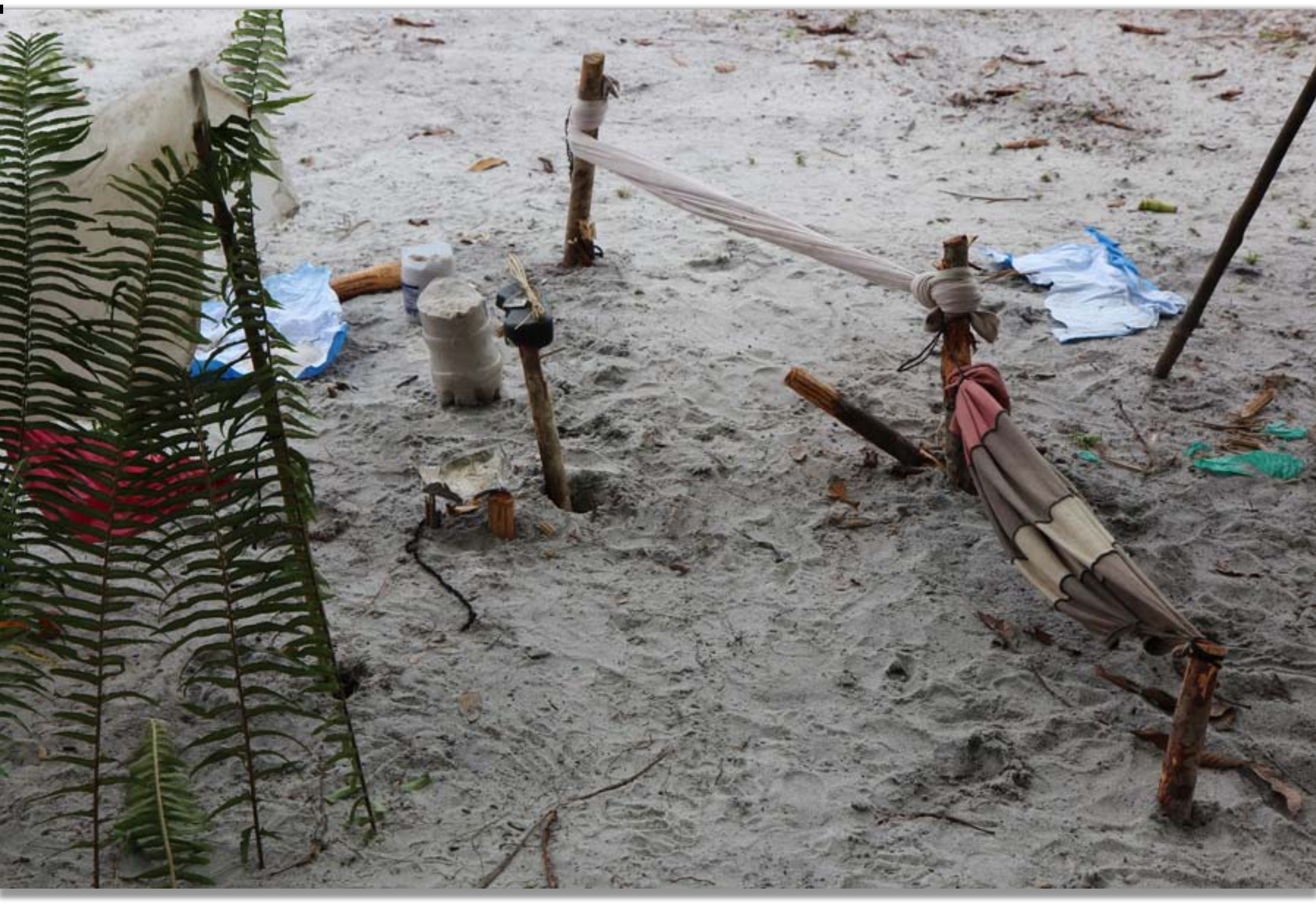




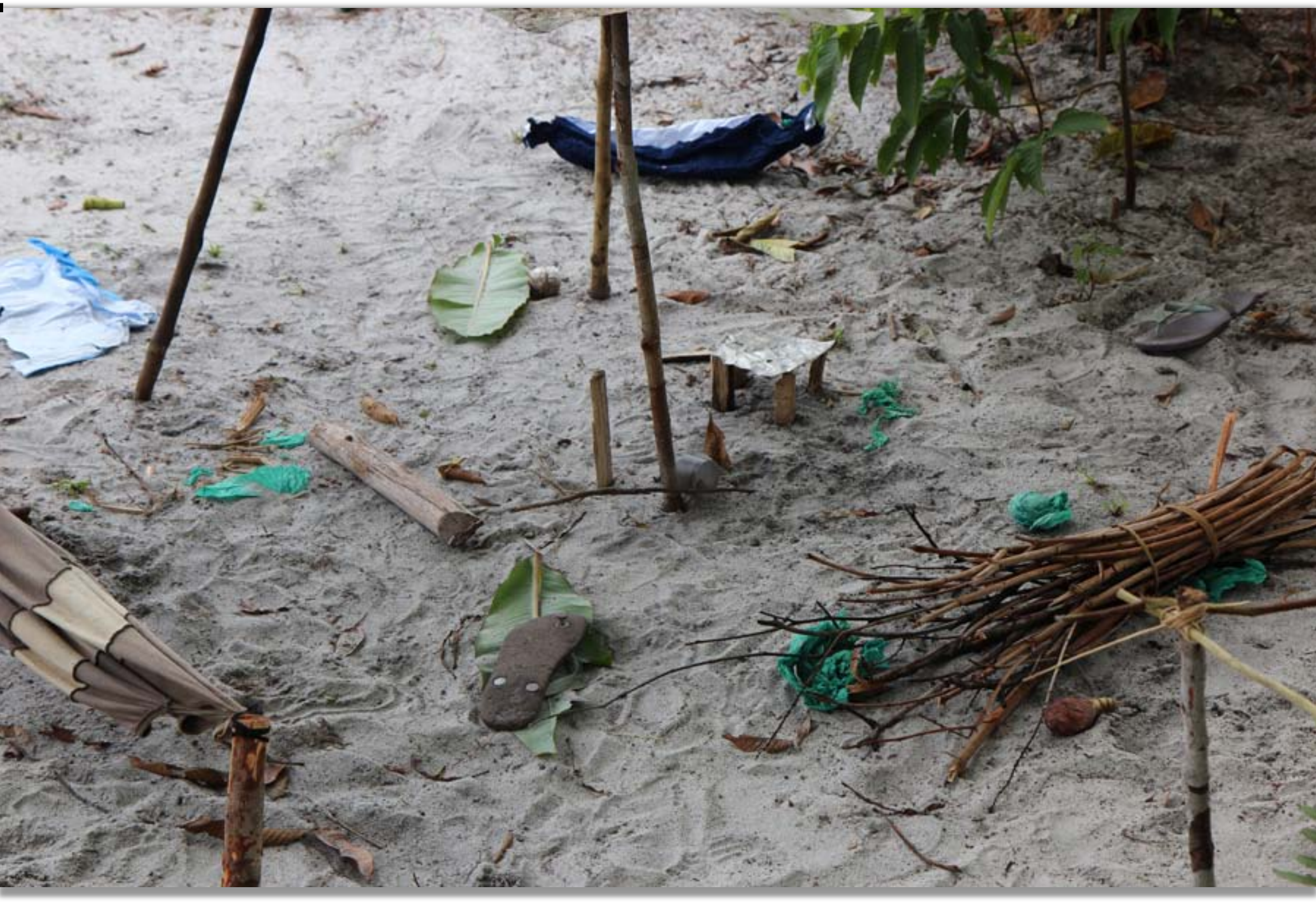




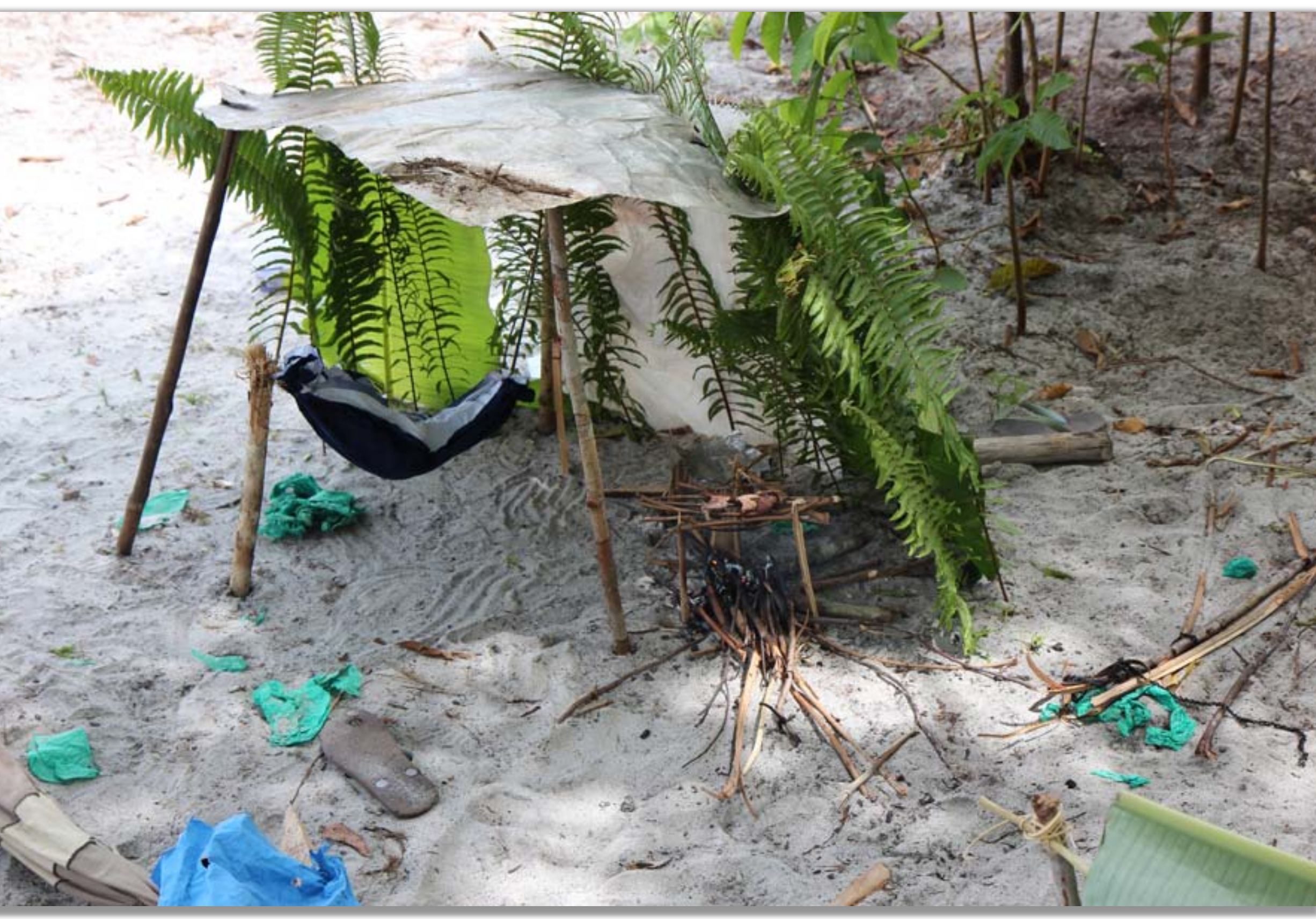




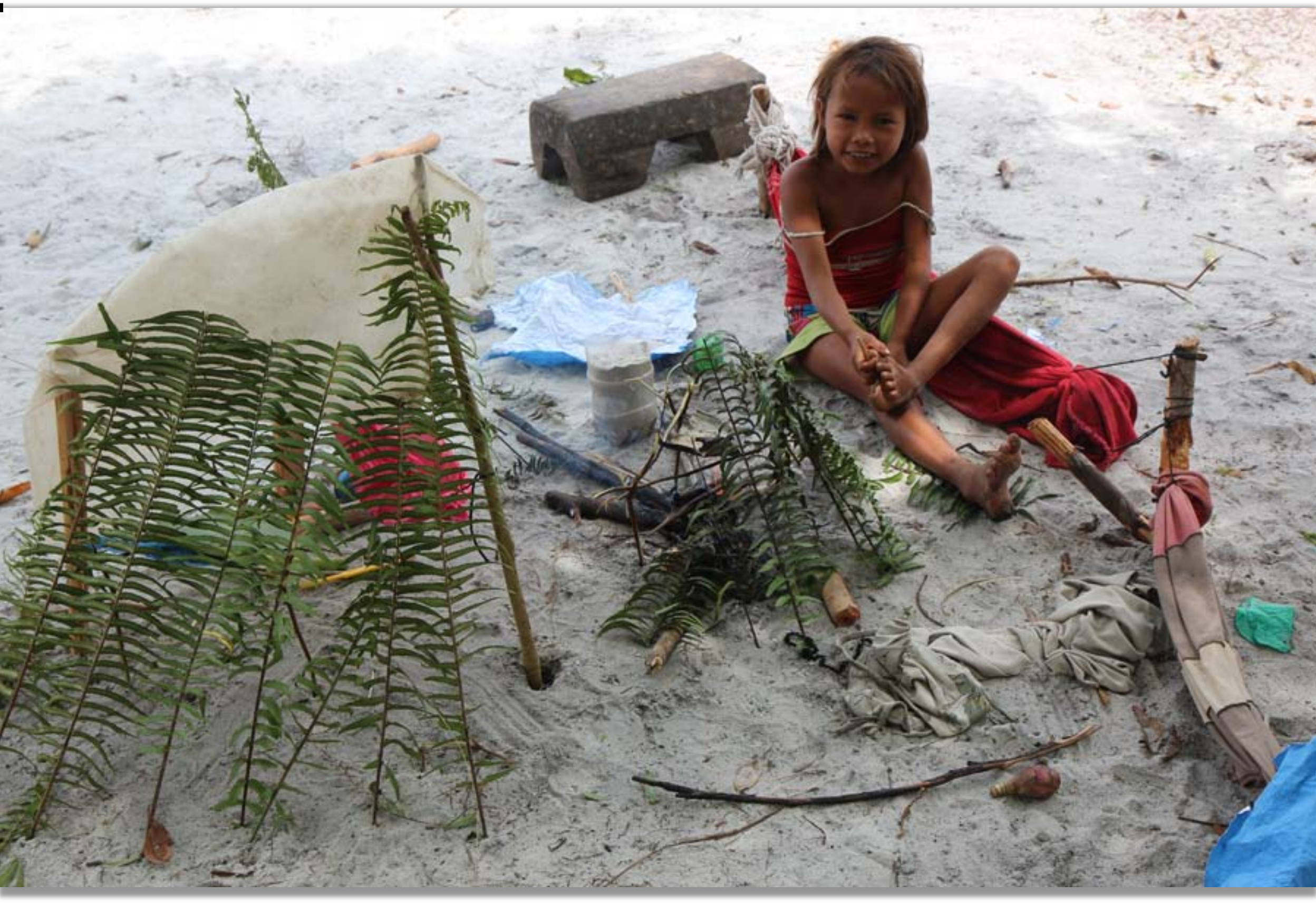




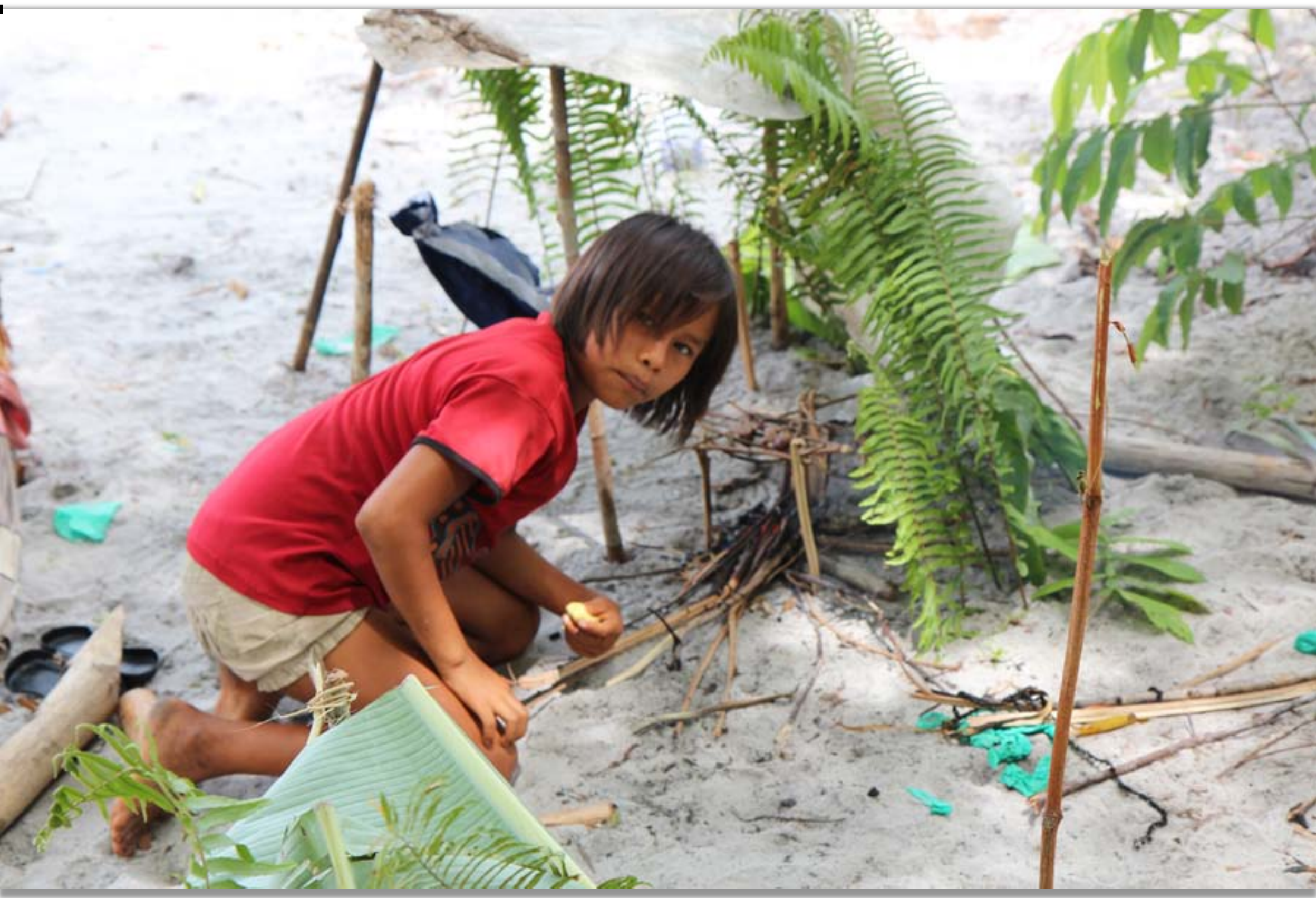




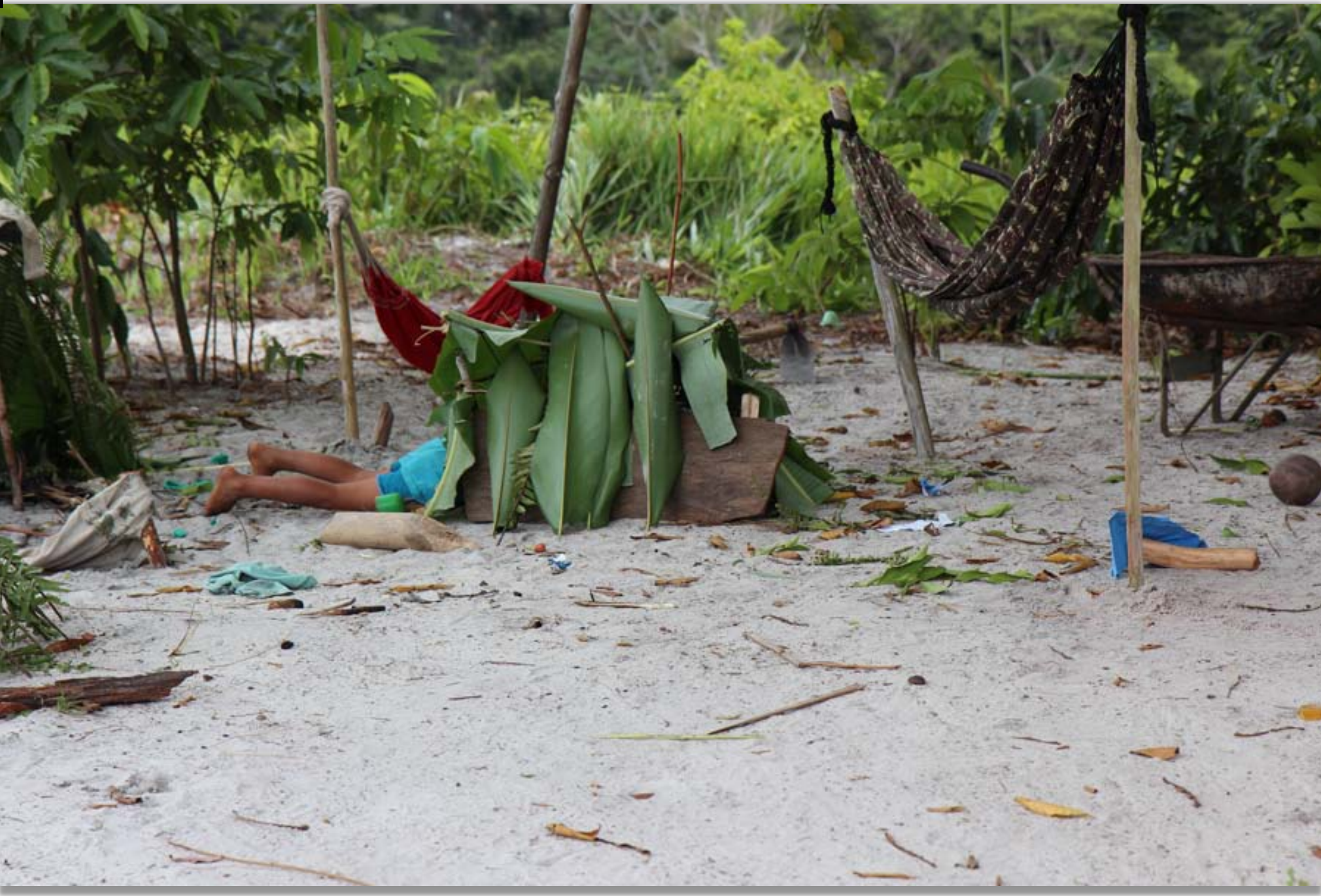




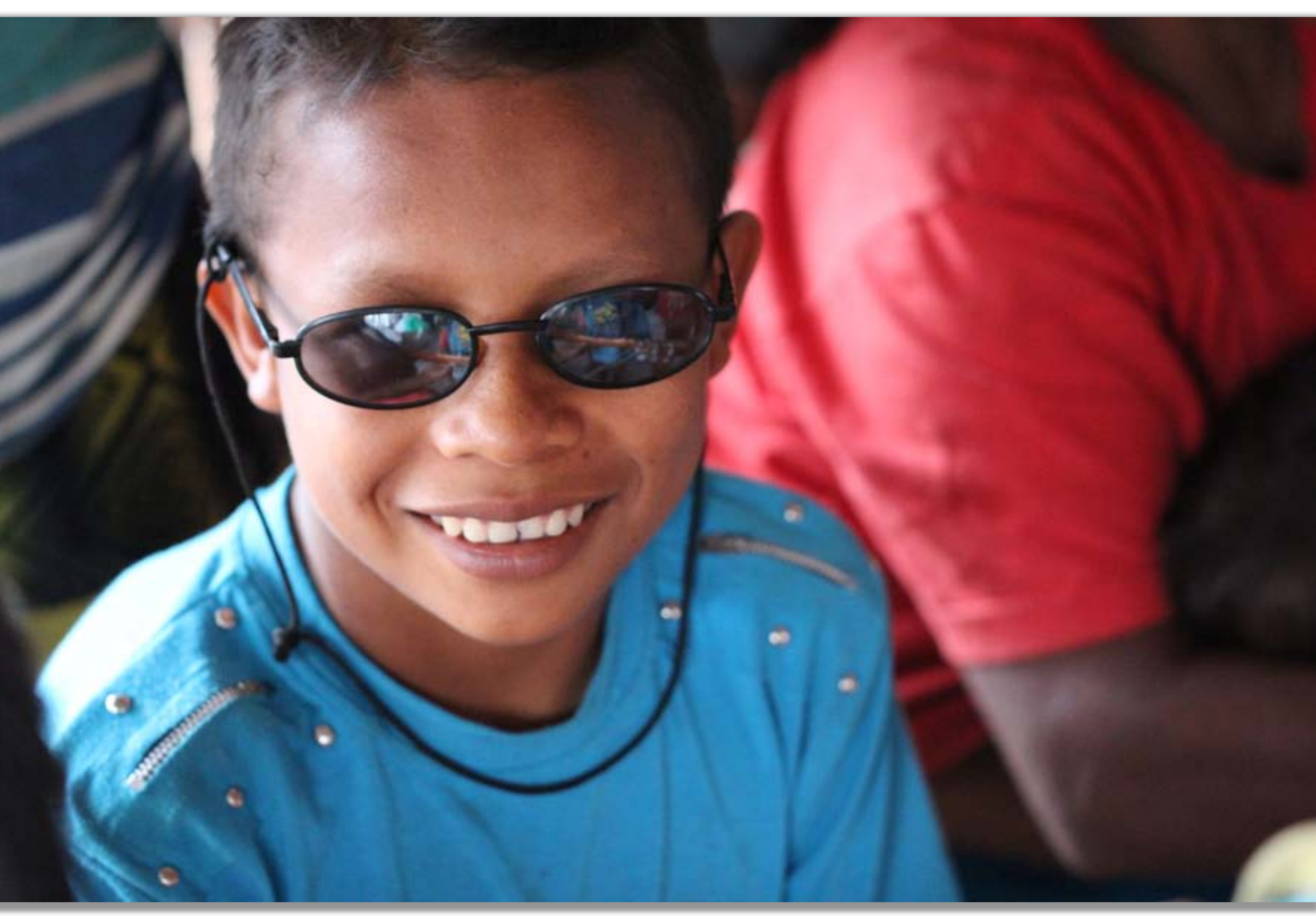




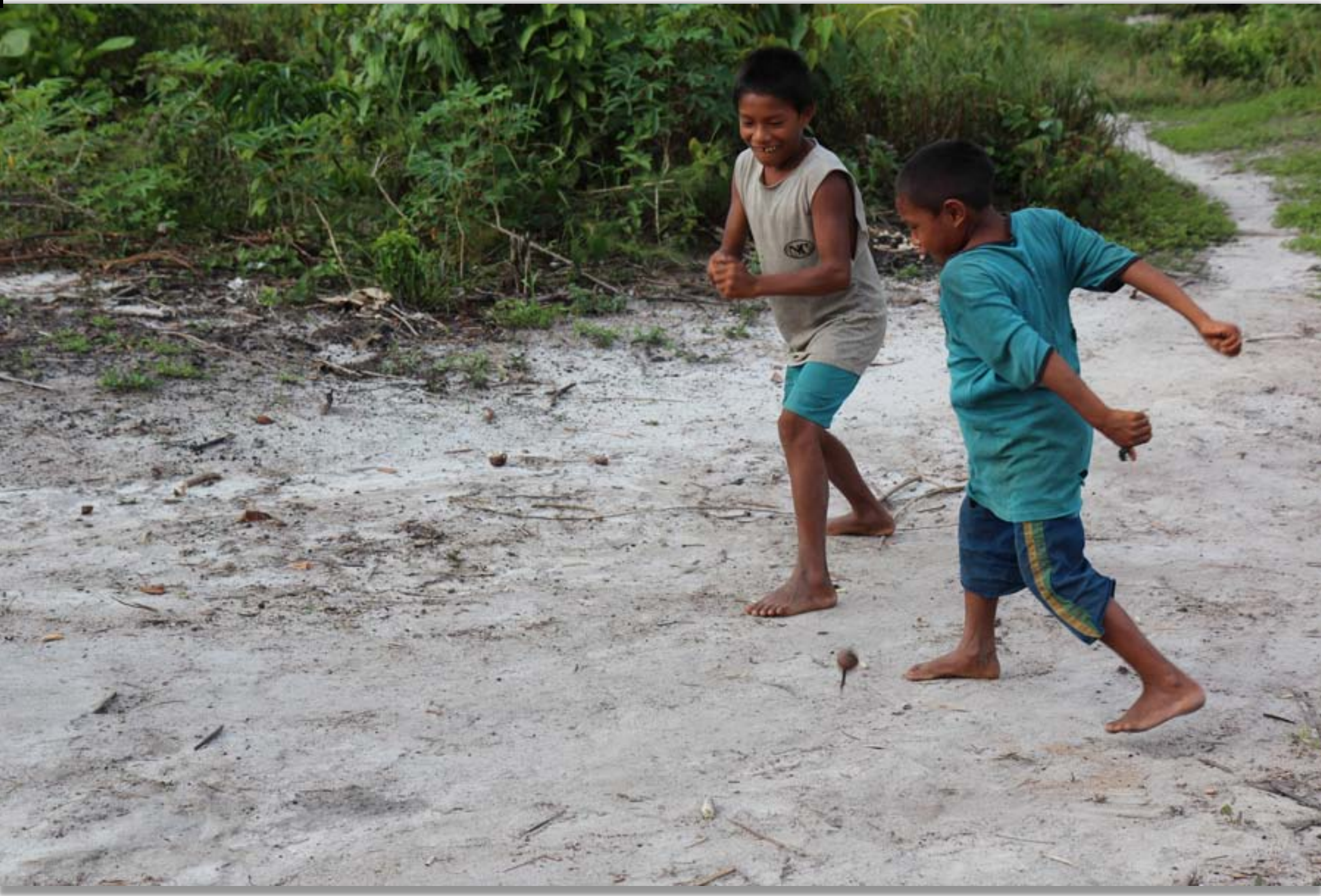

\section{Boys play with their spinning top}




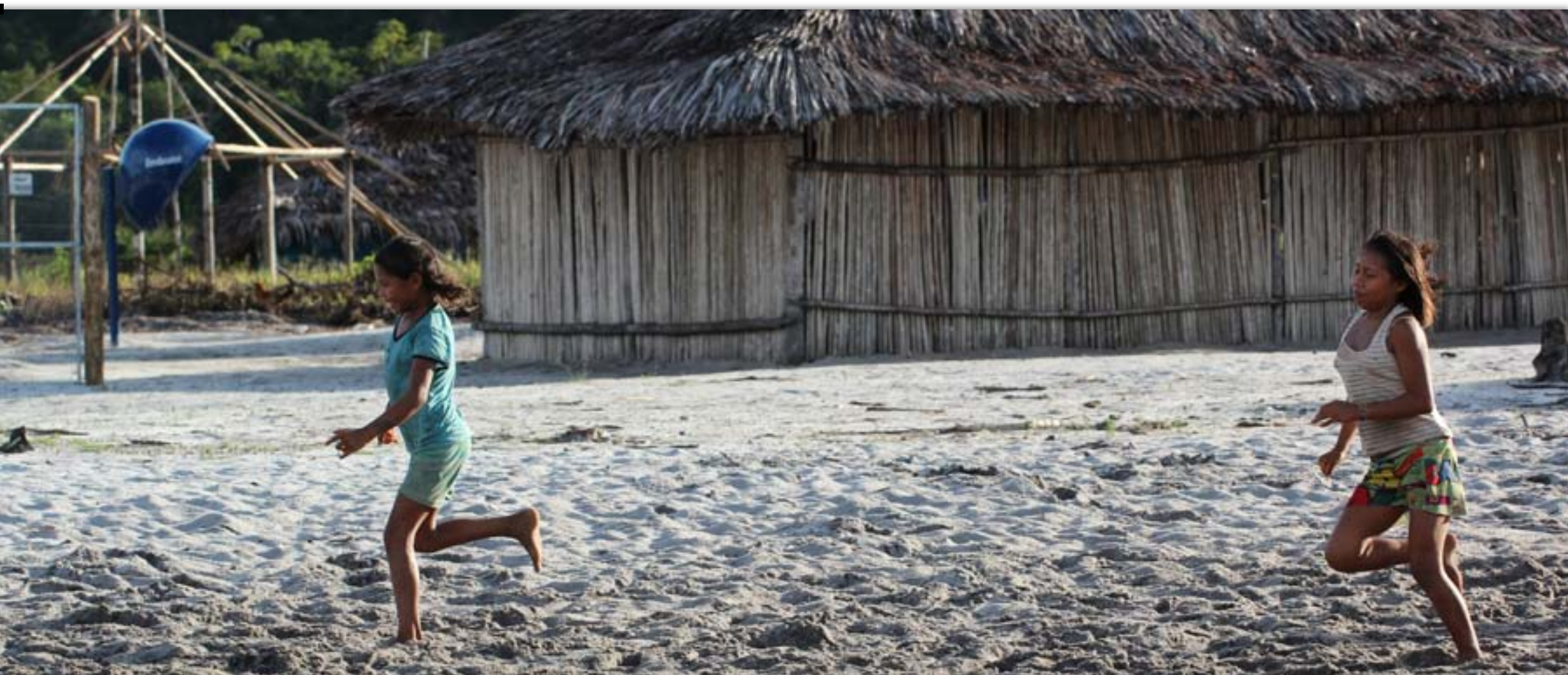

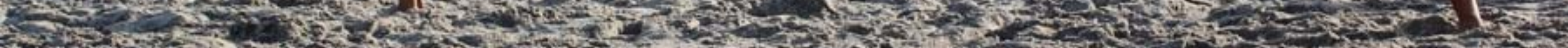

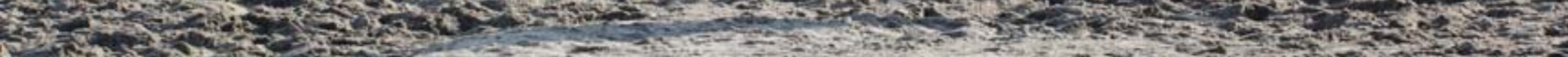

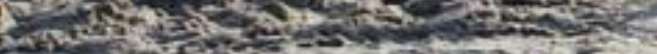

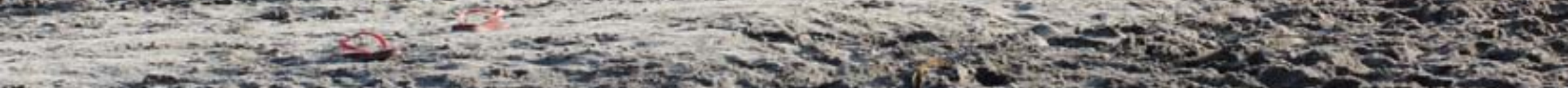

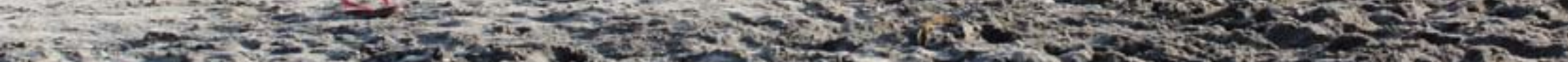

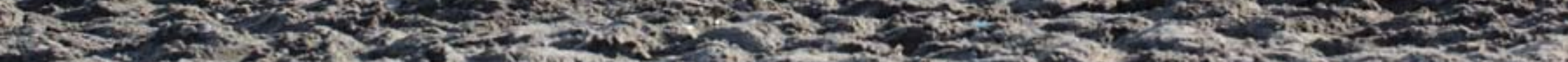

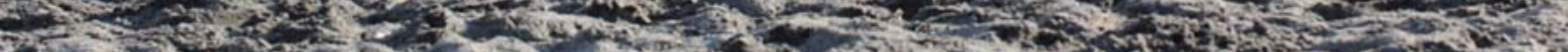

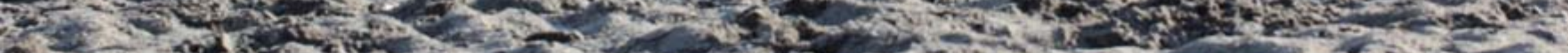

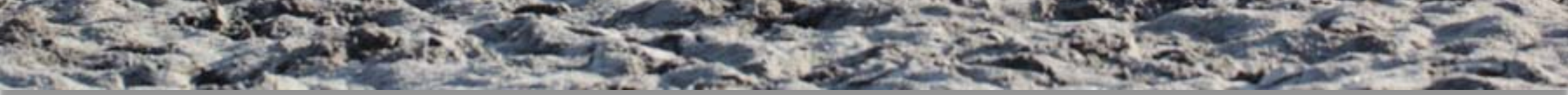
Girls' football in the sand in the centre of the village 
MUTIRÃO - working together 


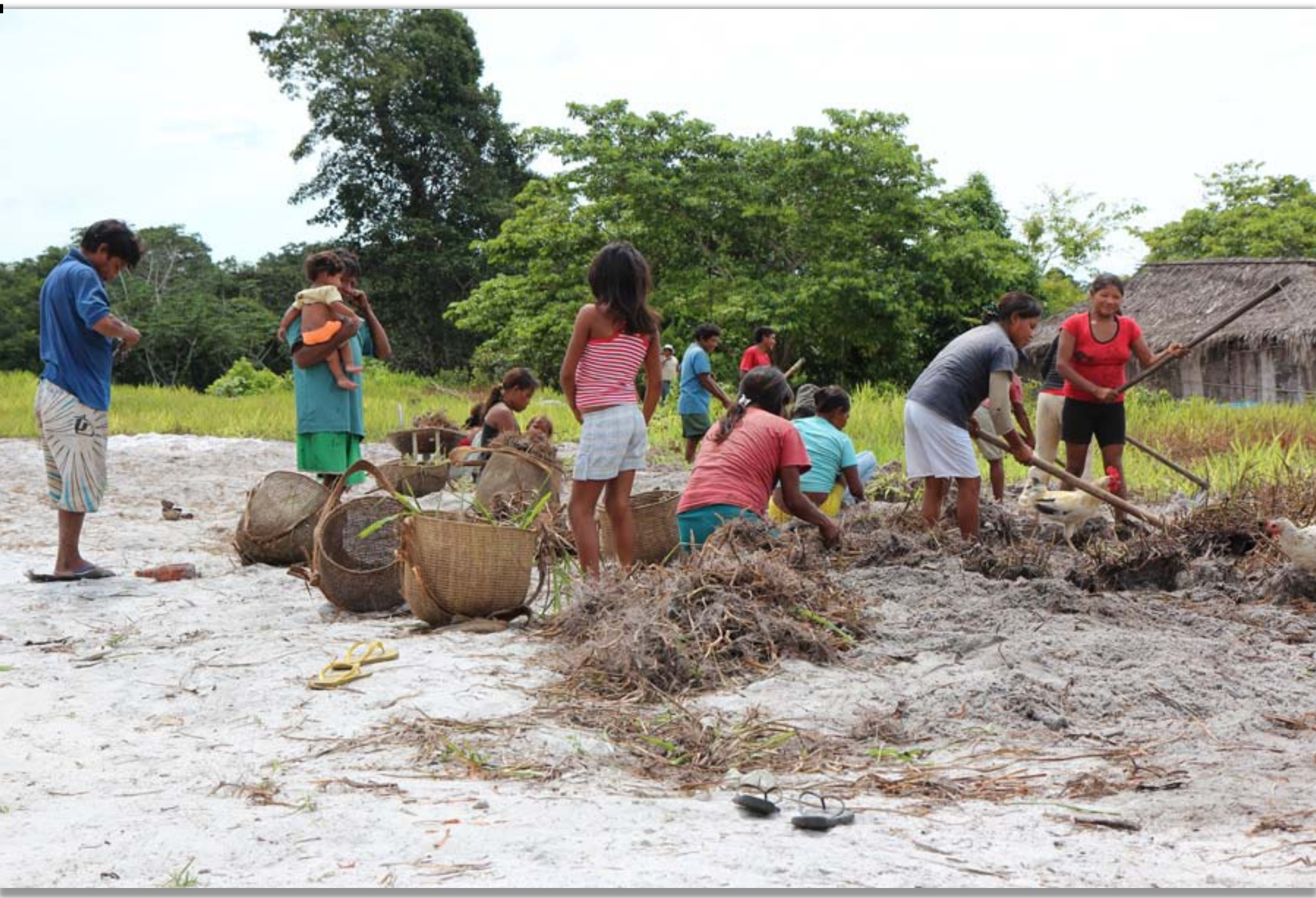

Families gather to clear the grass in front of their houses 


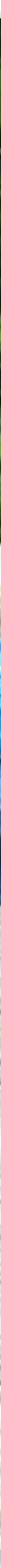




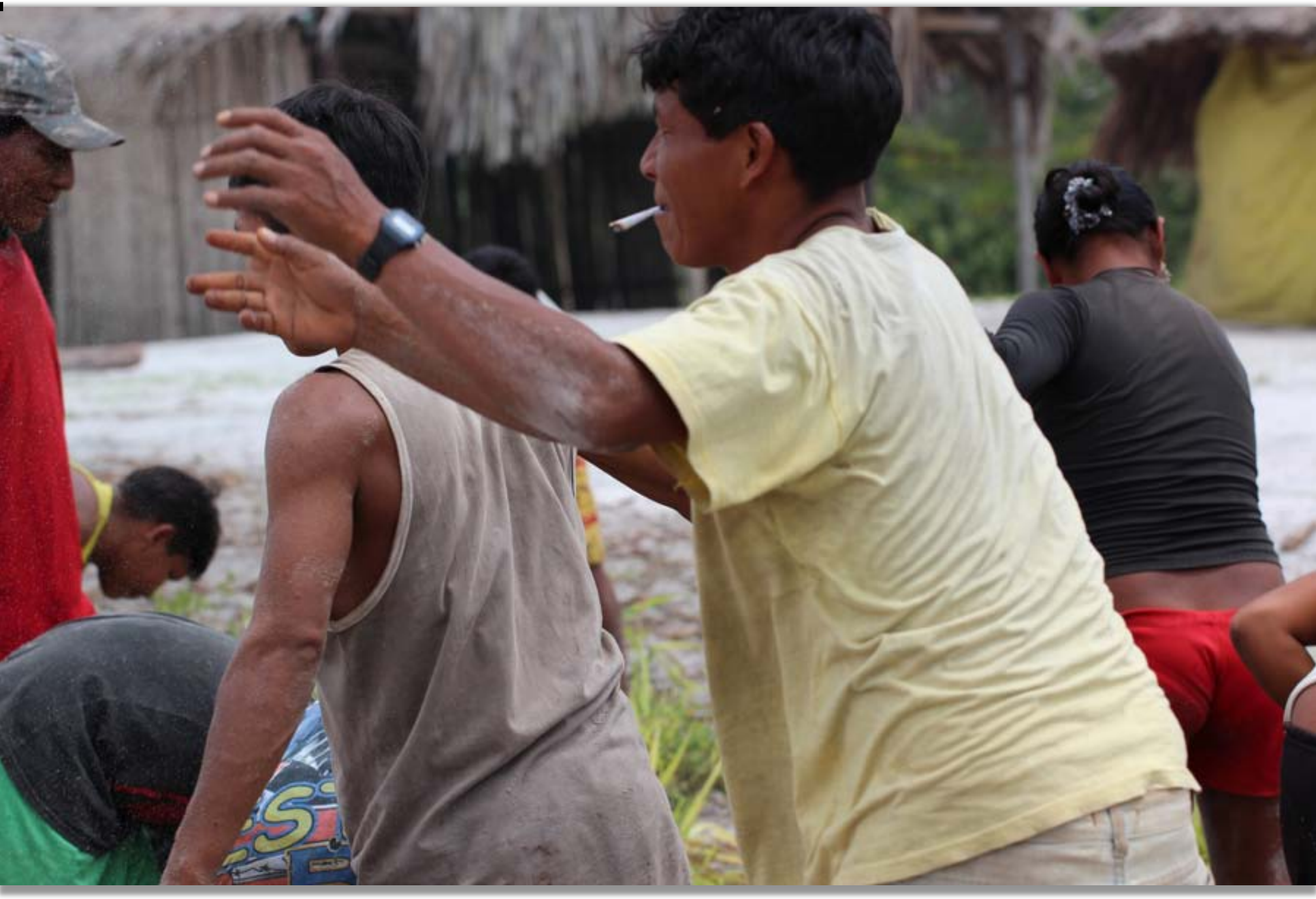




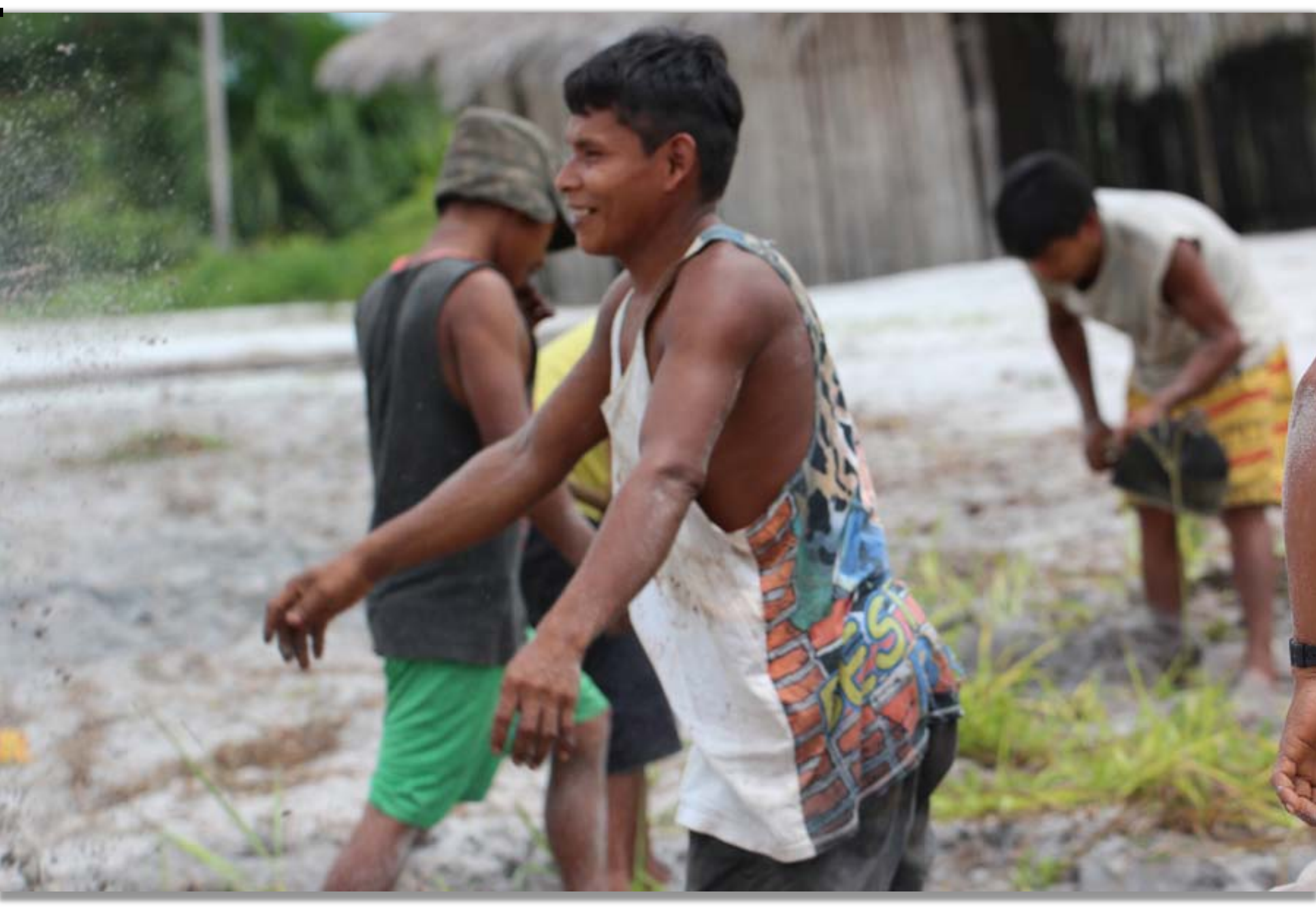




\section{$-5 \times x^{2} \times$ . \\ Tos}

(2x) H. If

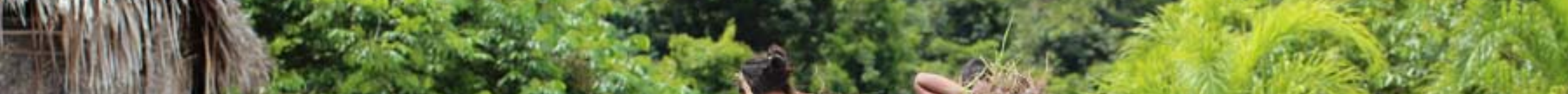

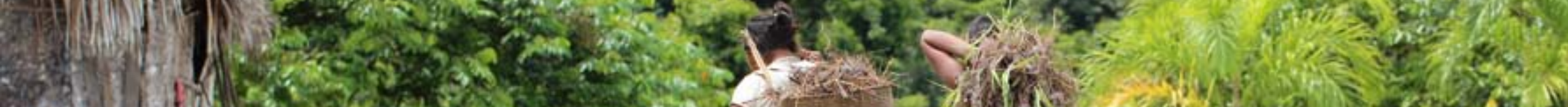
20.
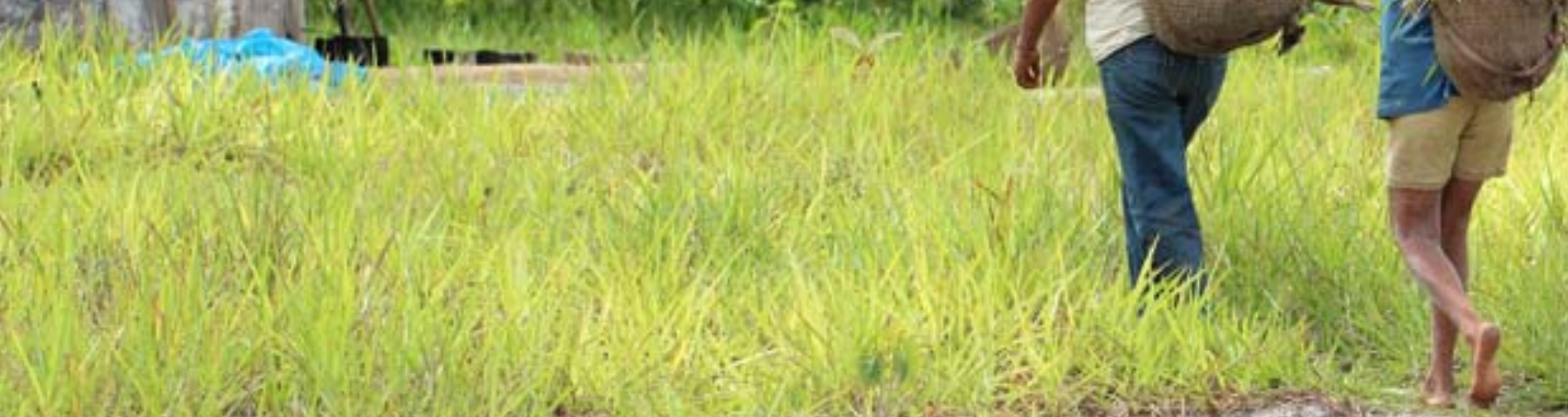

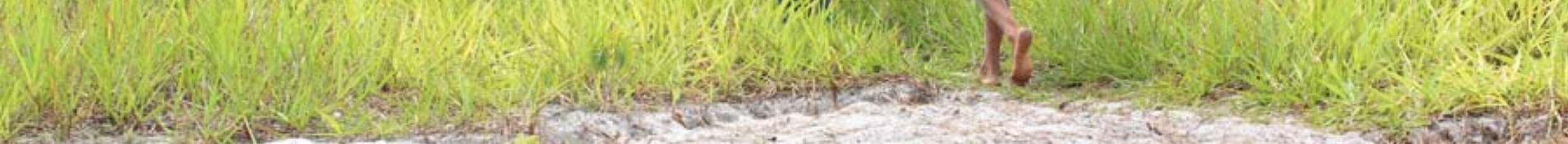

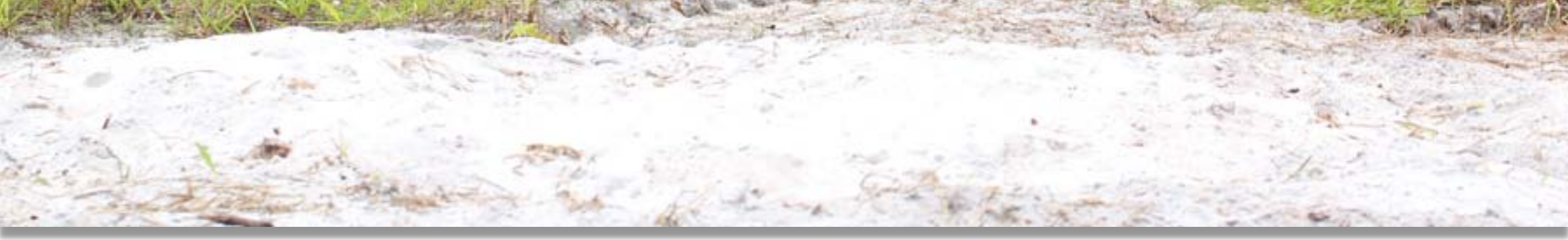


PETS 


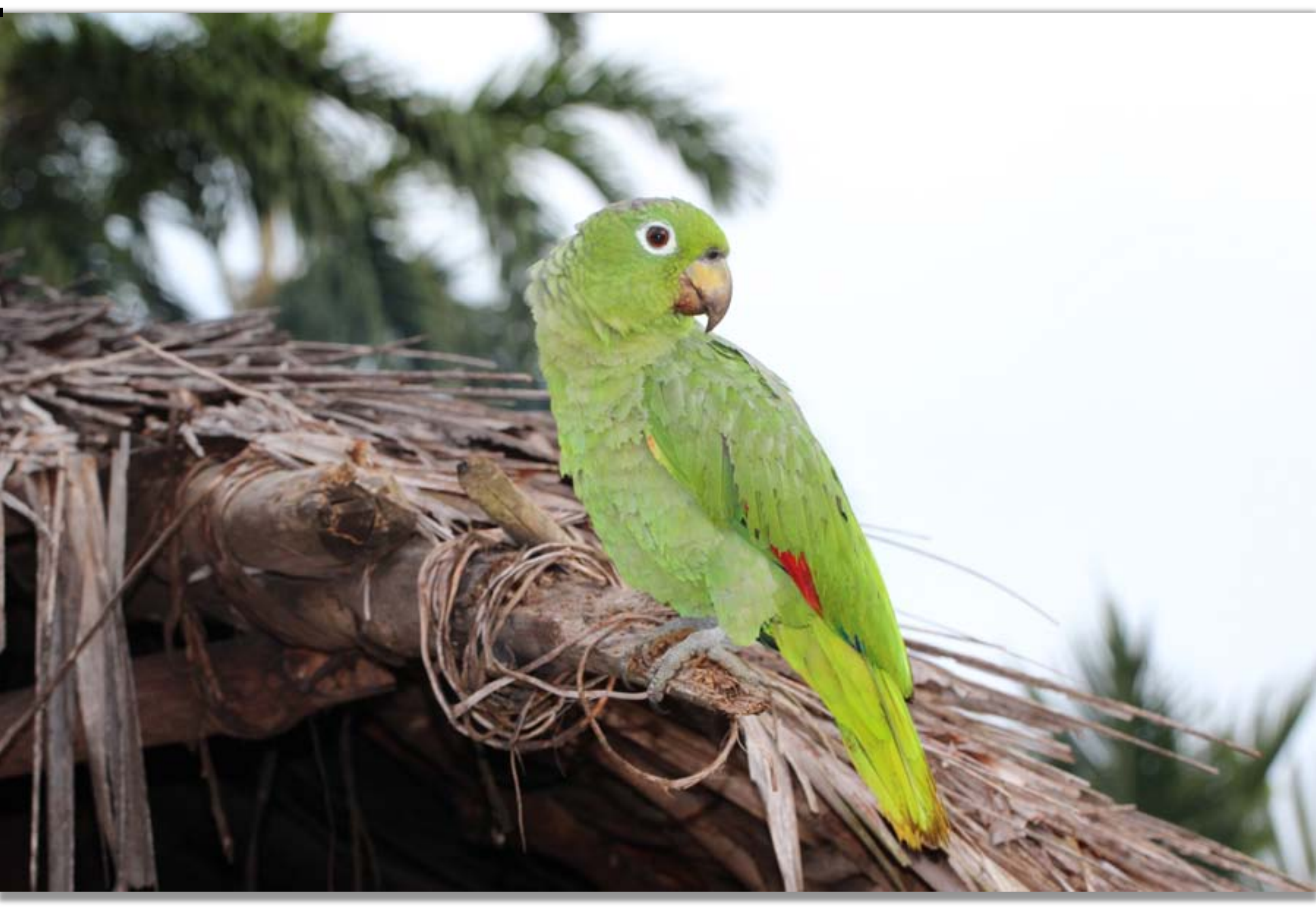




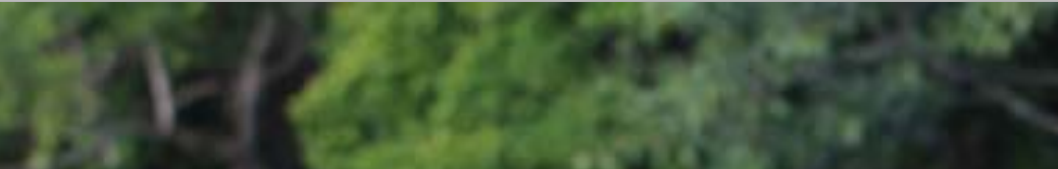 \\ $\sqrt{2}$

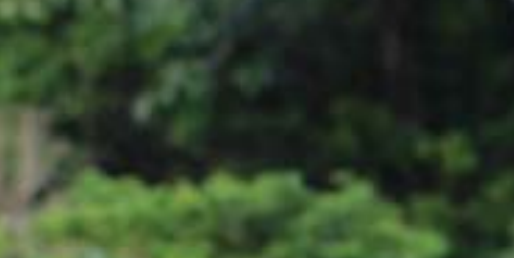

(2)

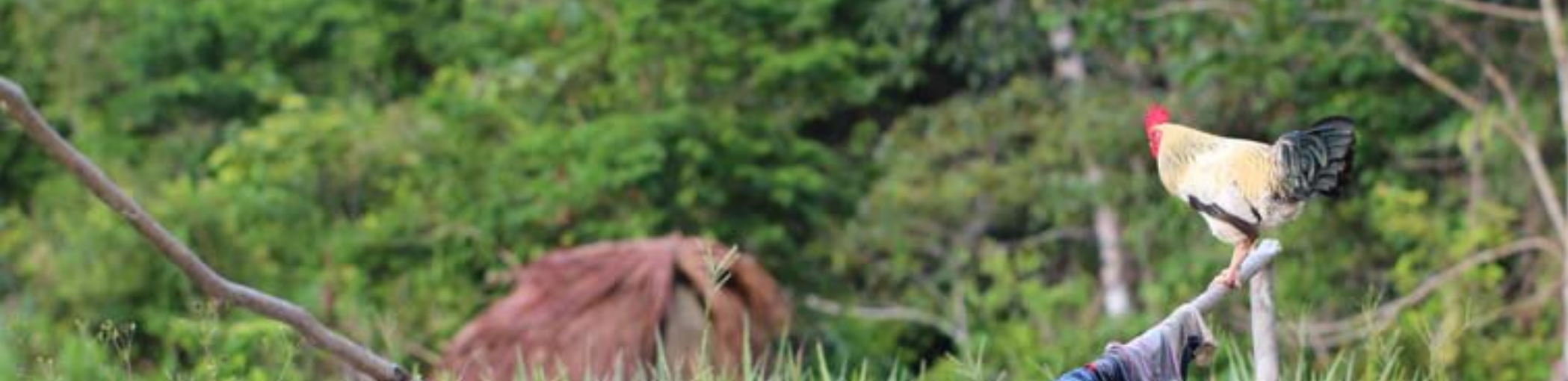

कo.

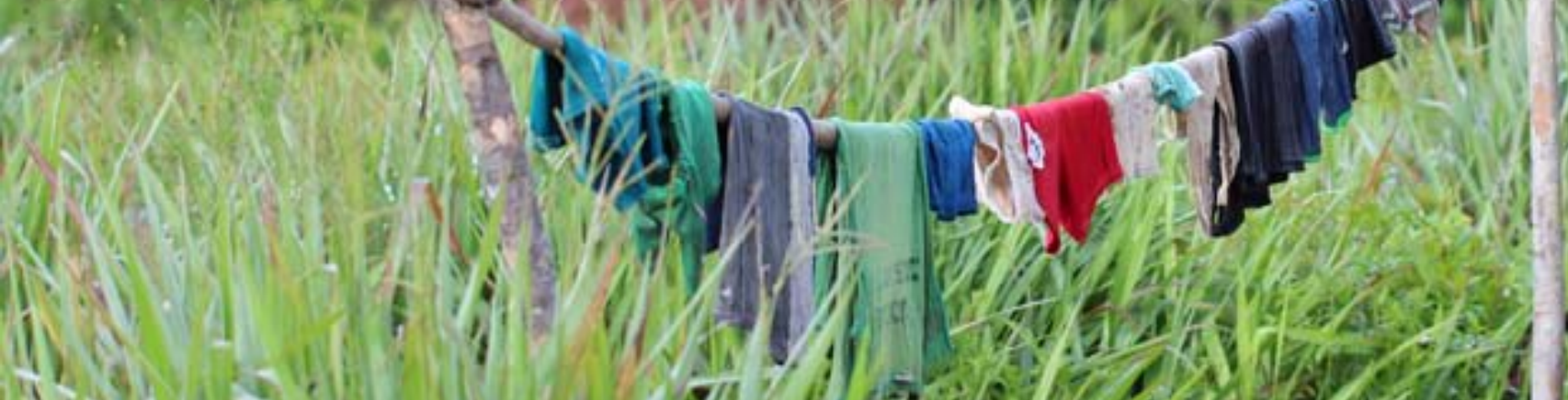

(3) (1) di.

(4) $4+24=119$
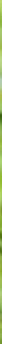

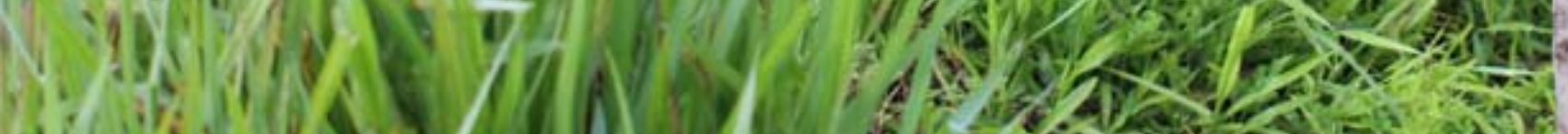

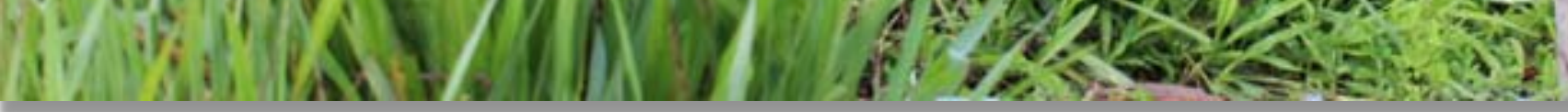

senent? 


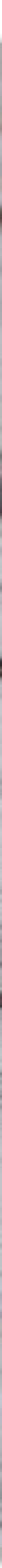




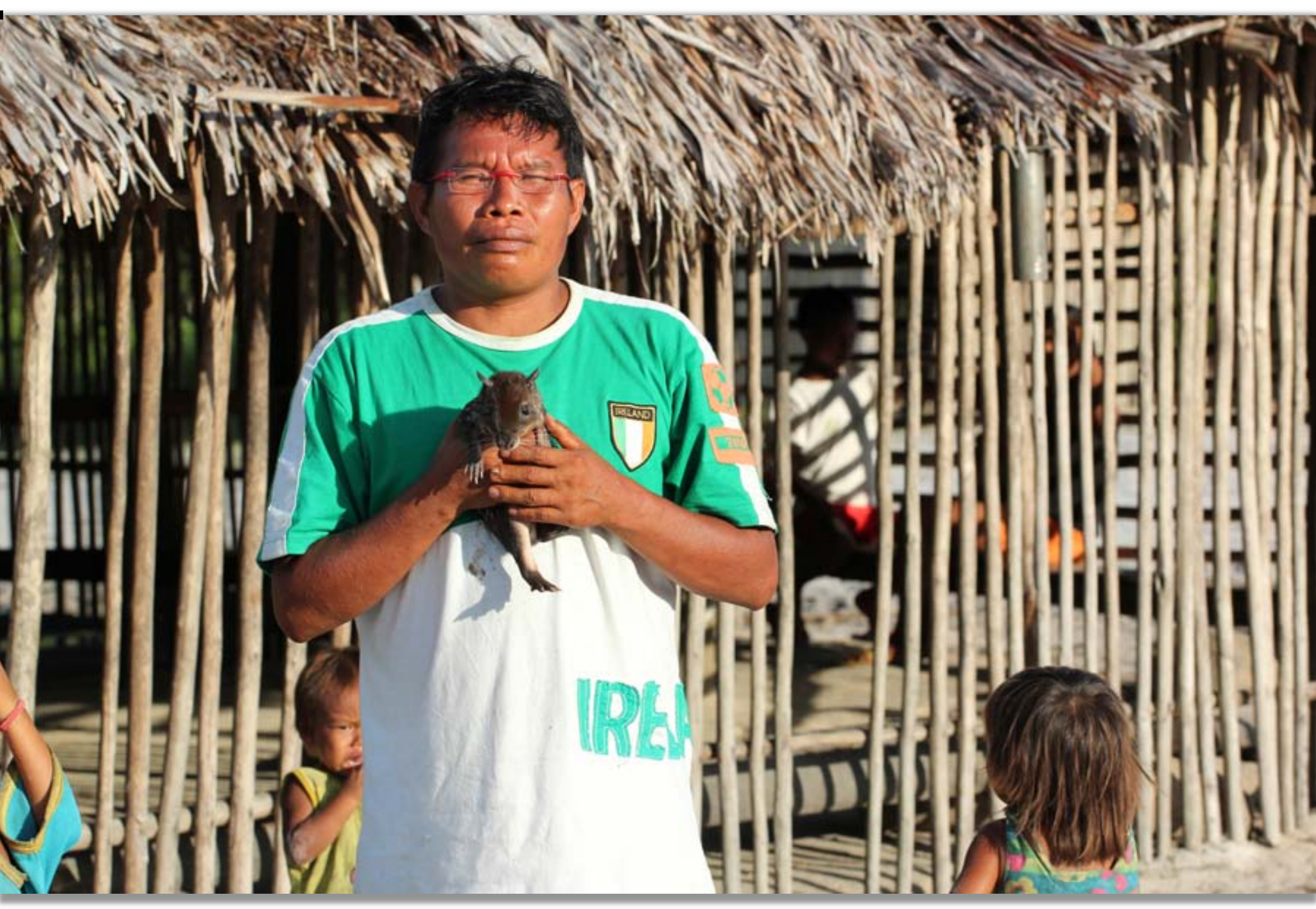




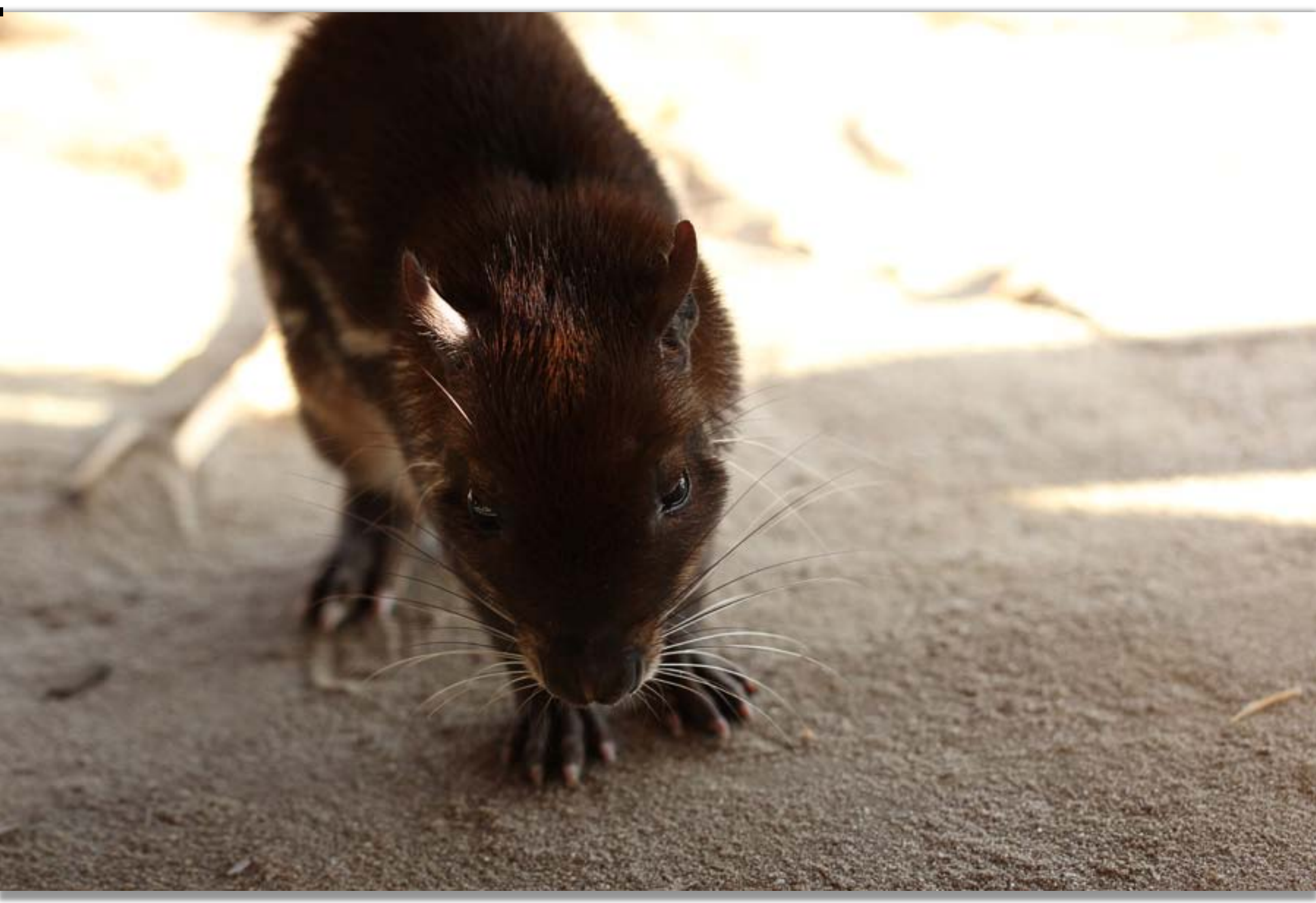




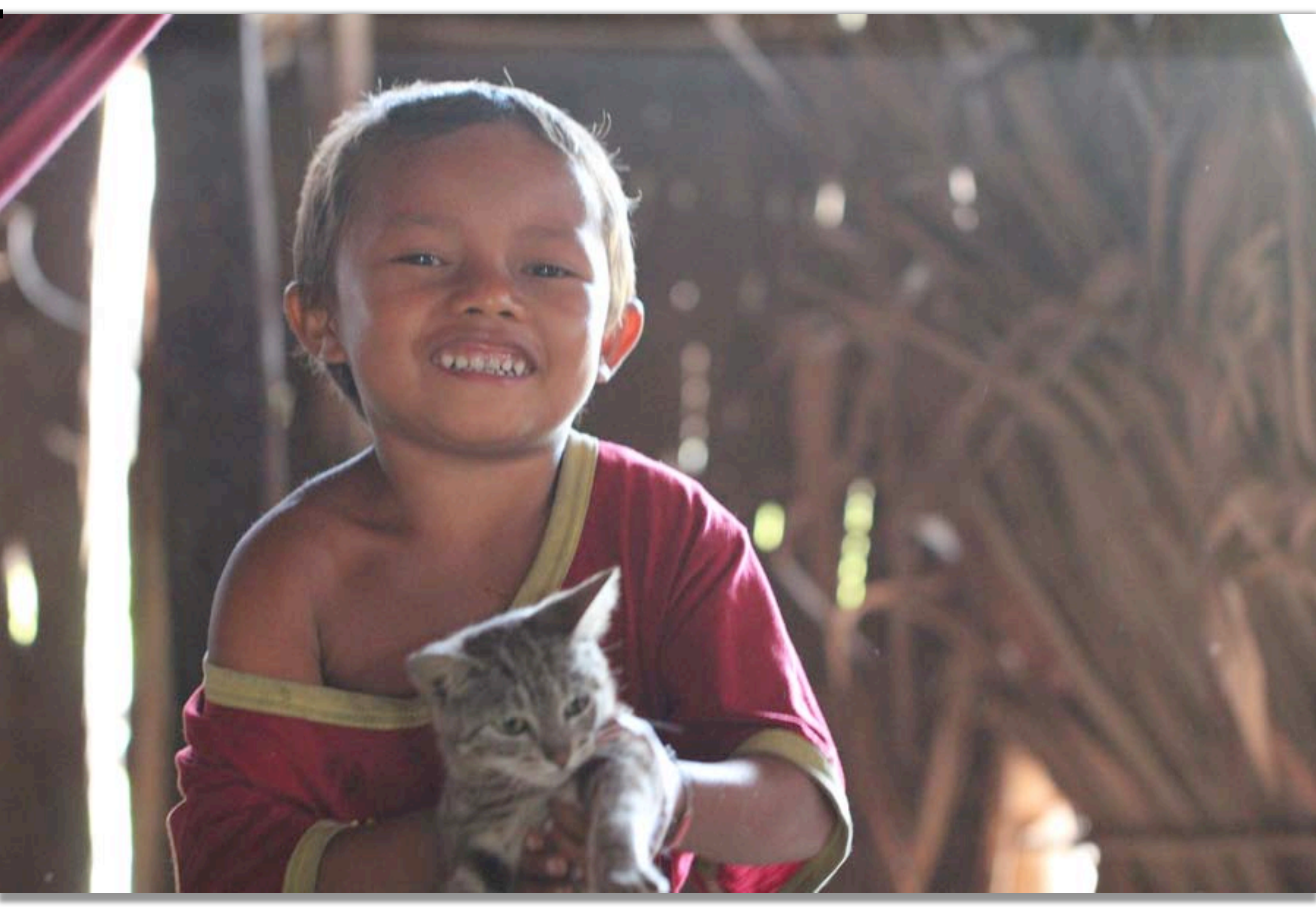




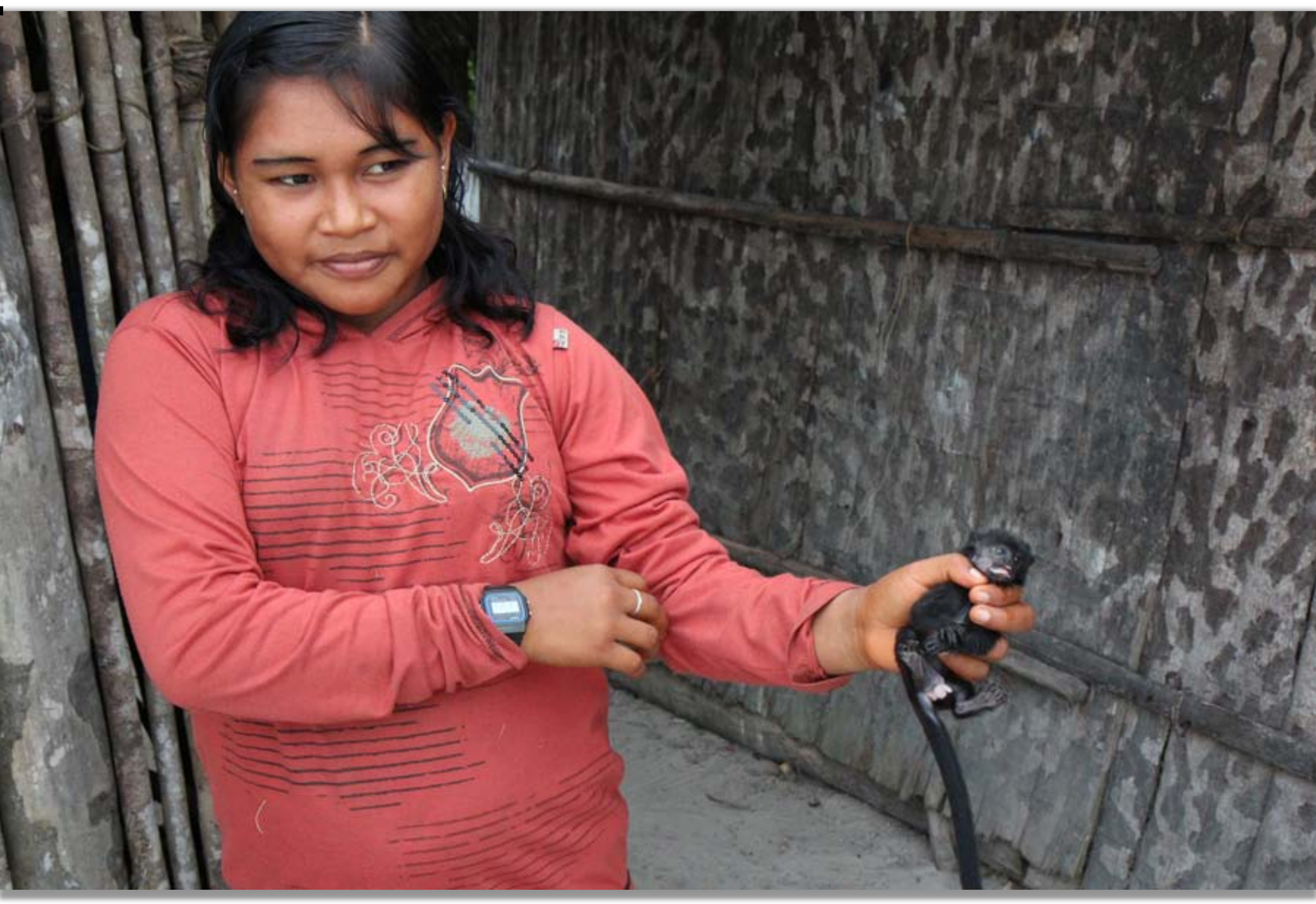


MATERIAL CULTURE 


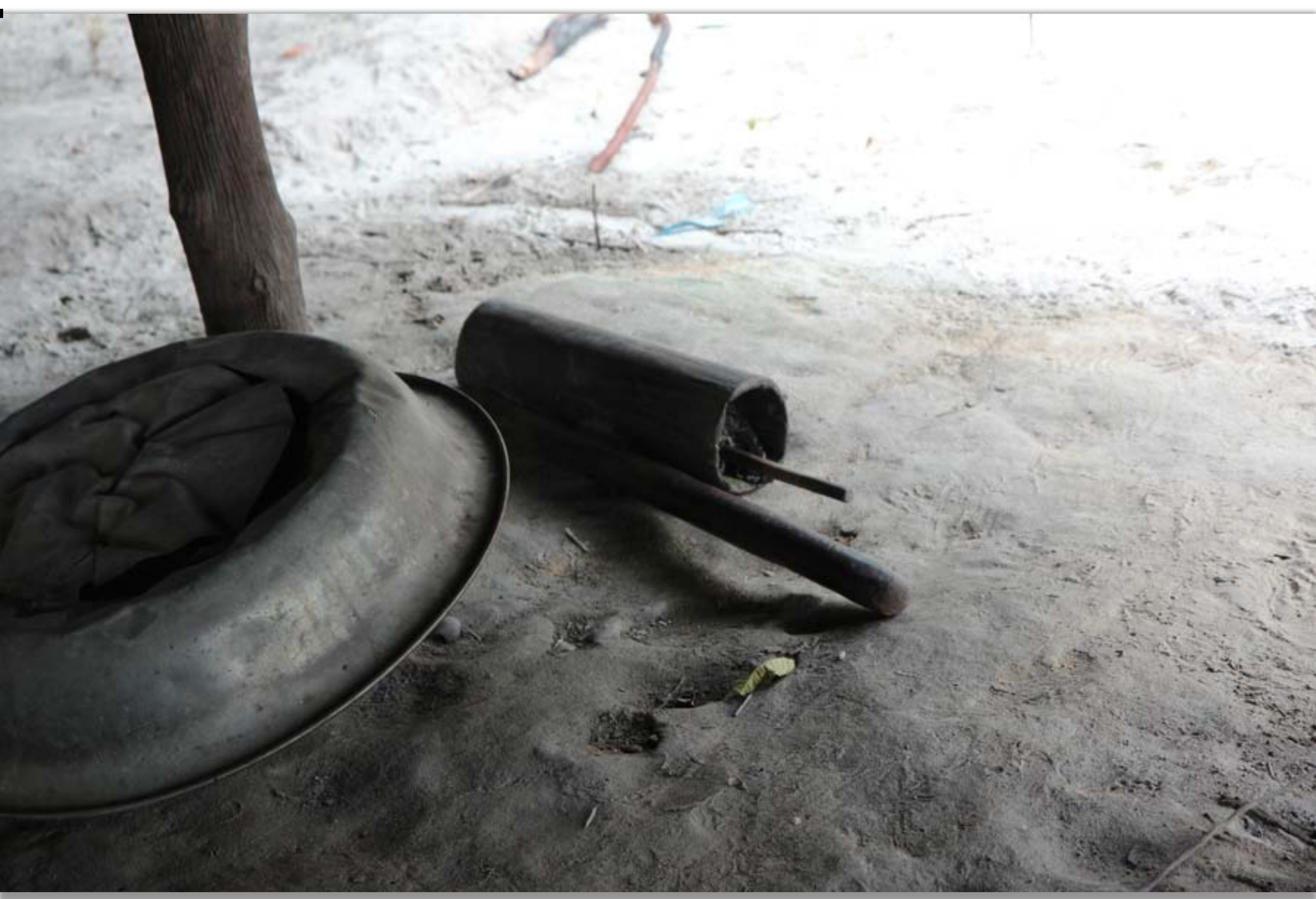

Wooden mortar to soak coca leaves 


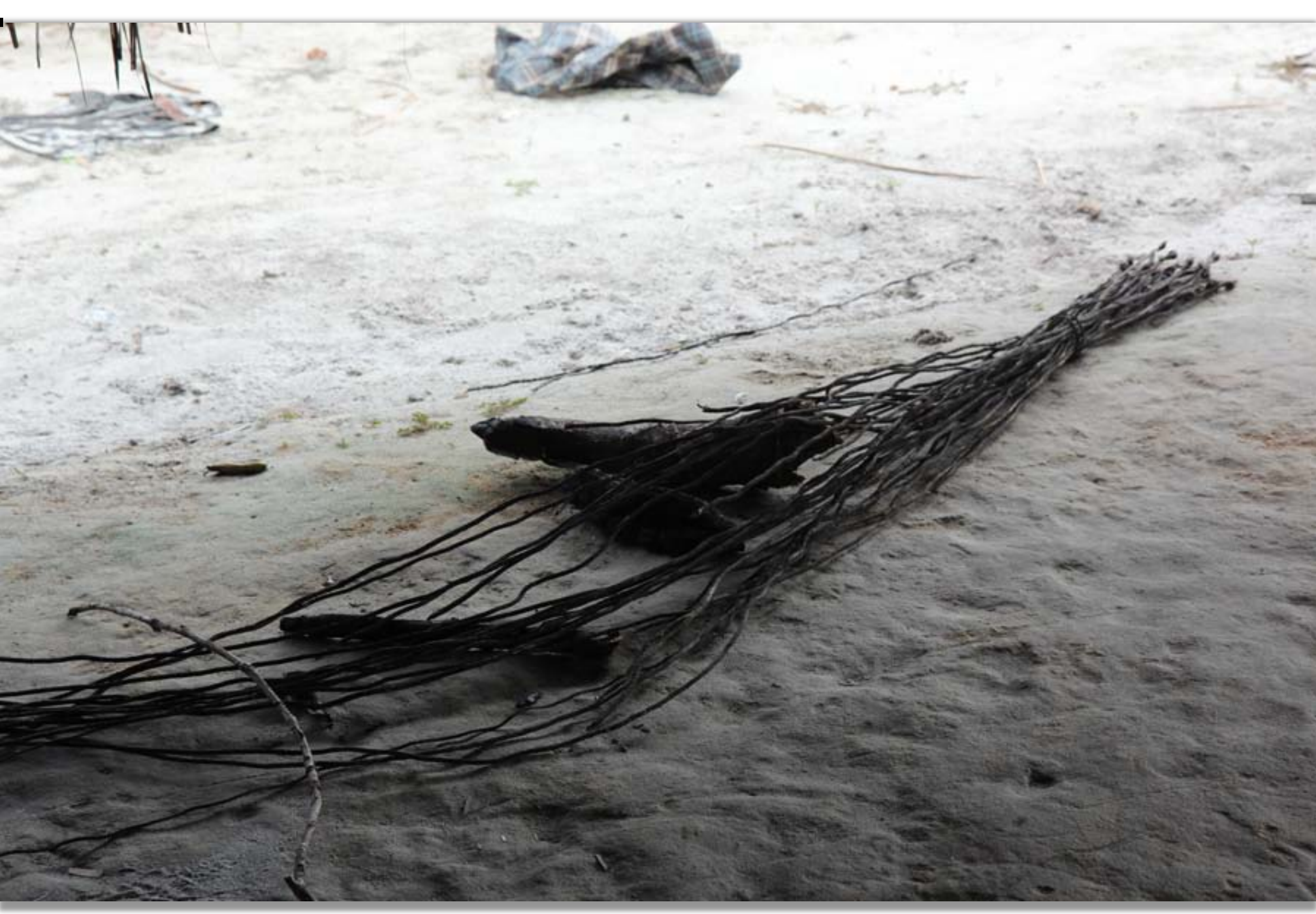

Vine to make baskets 


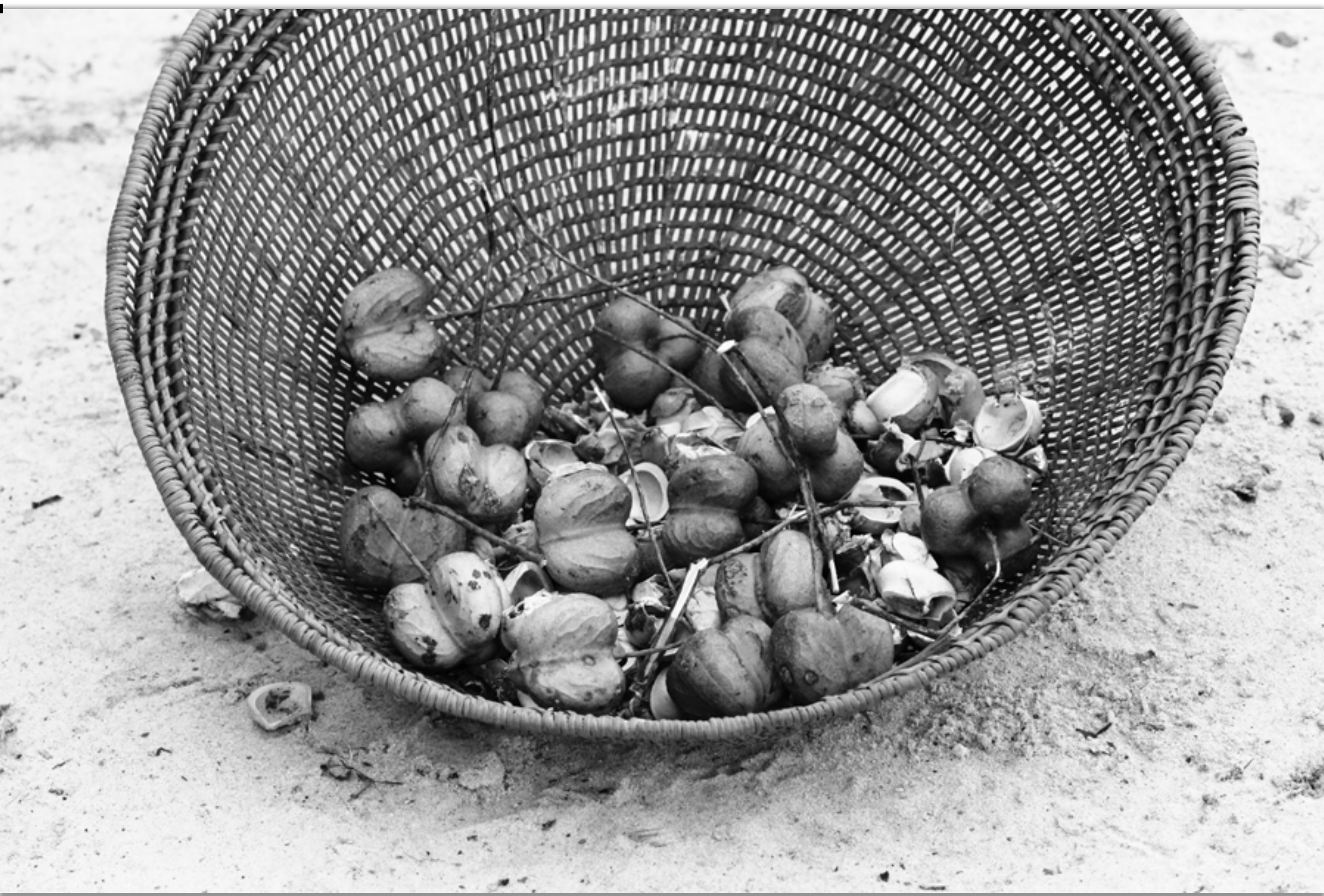




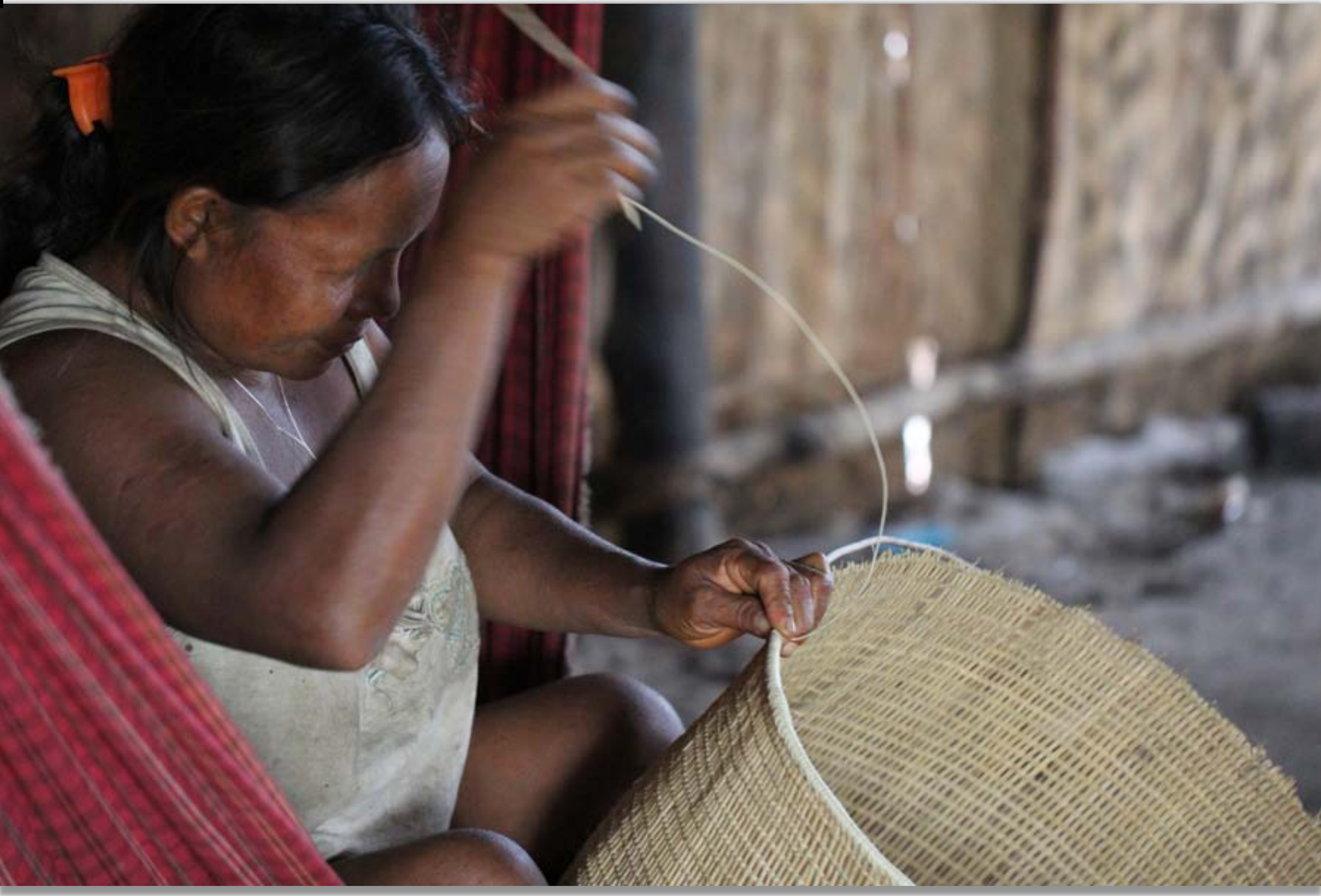

Baskets are always made by women 

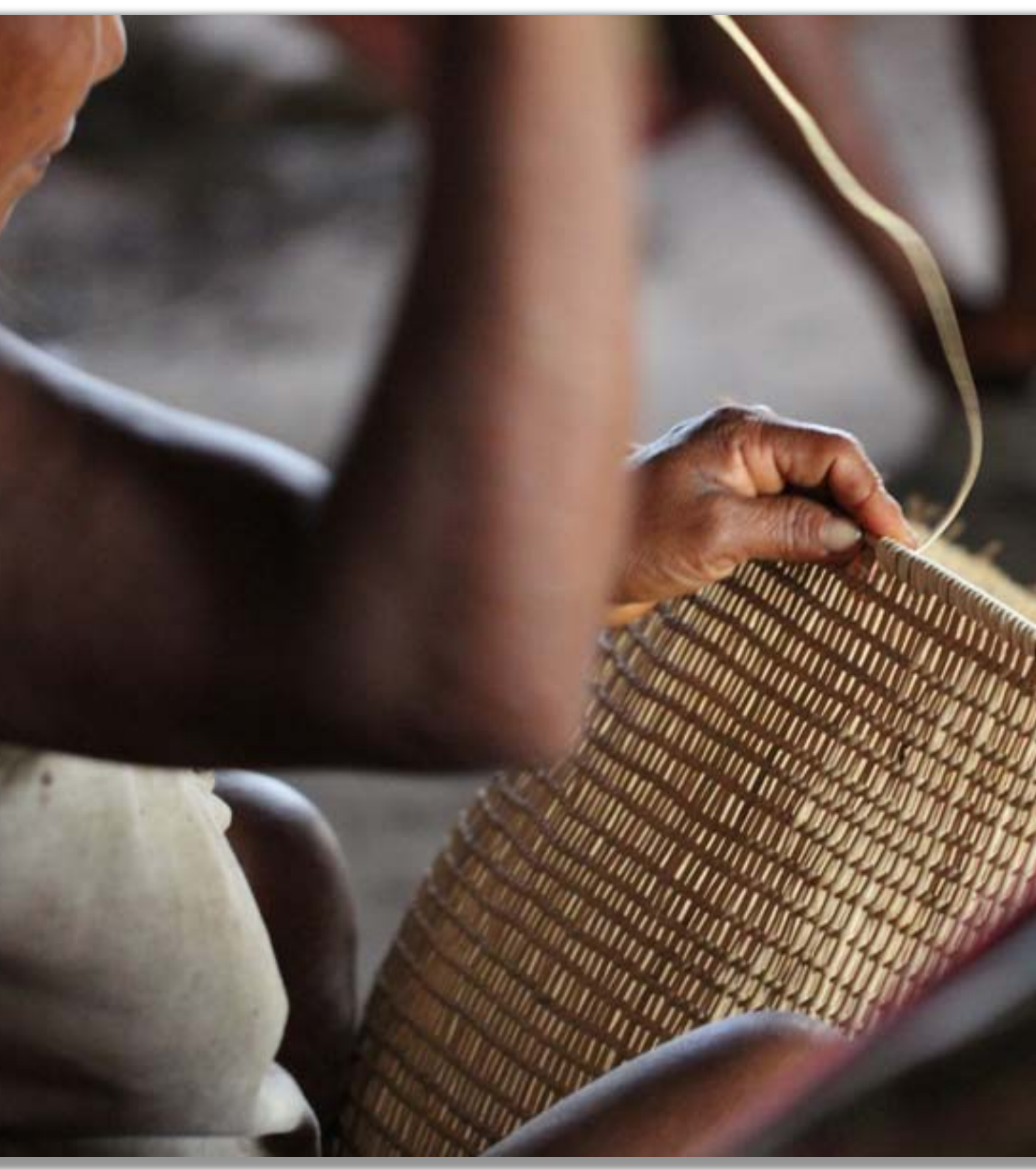


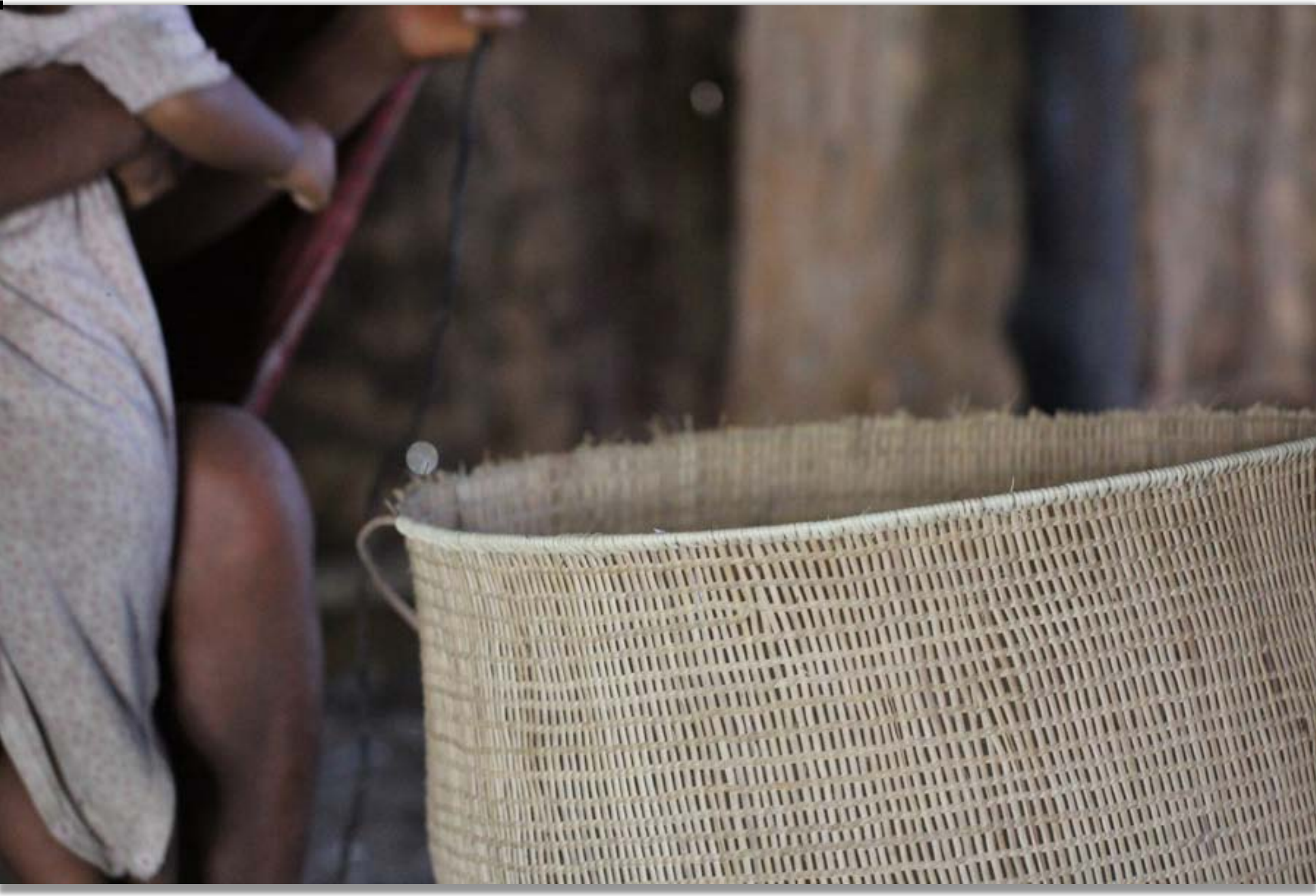




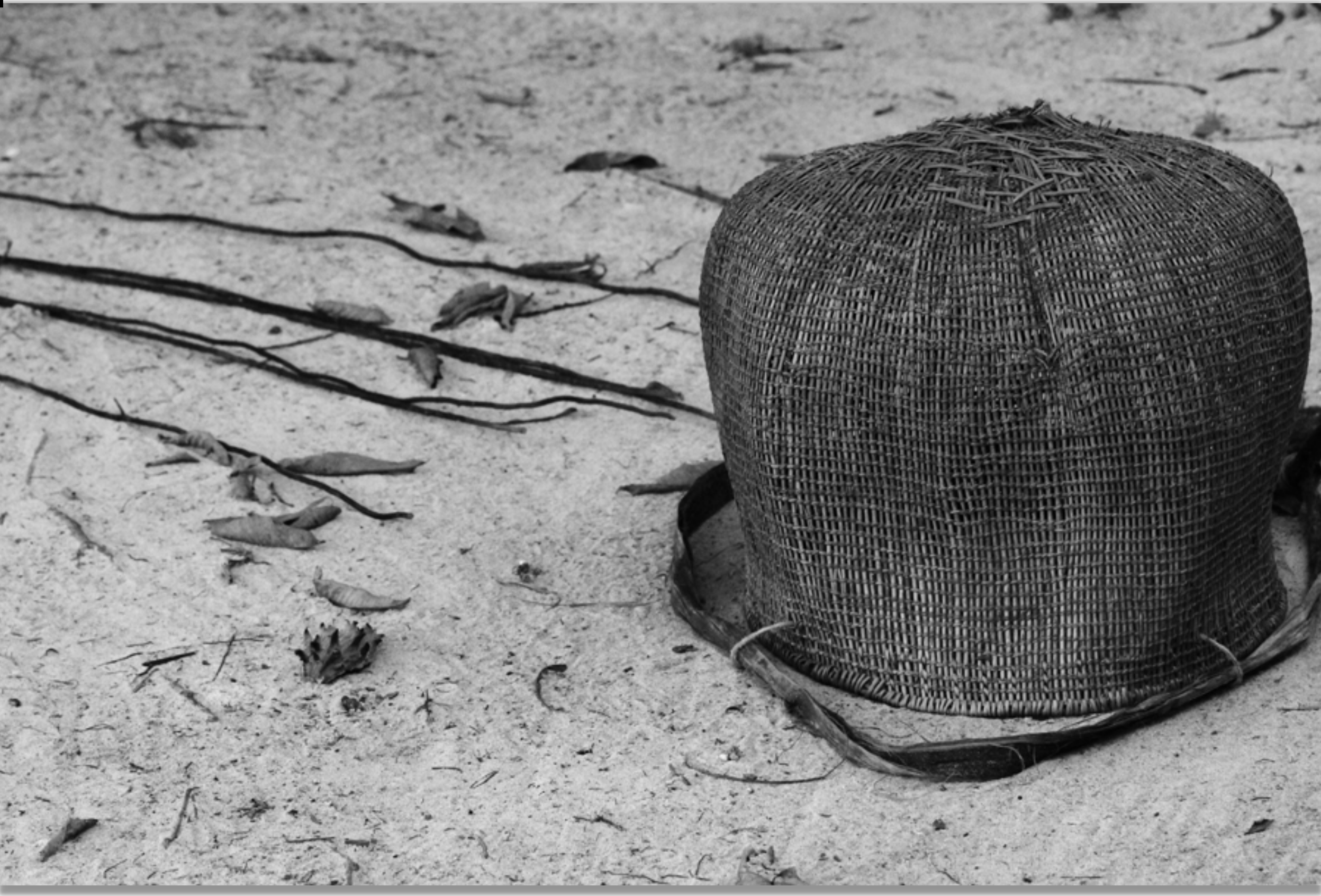




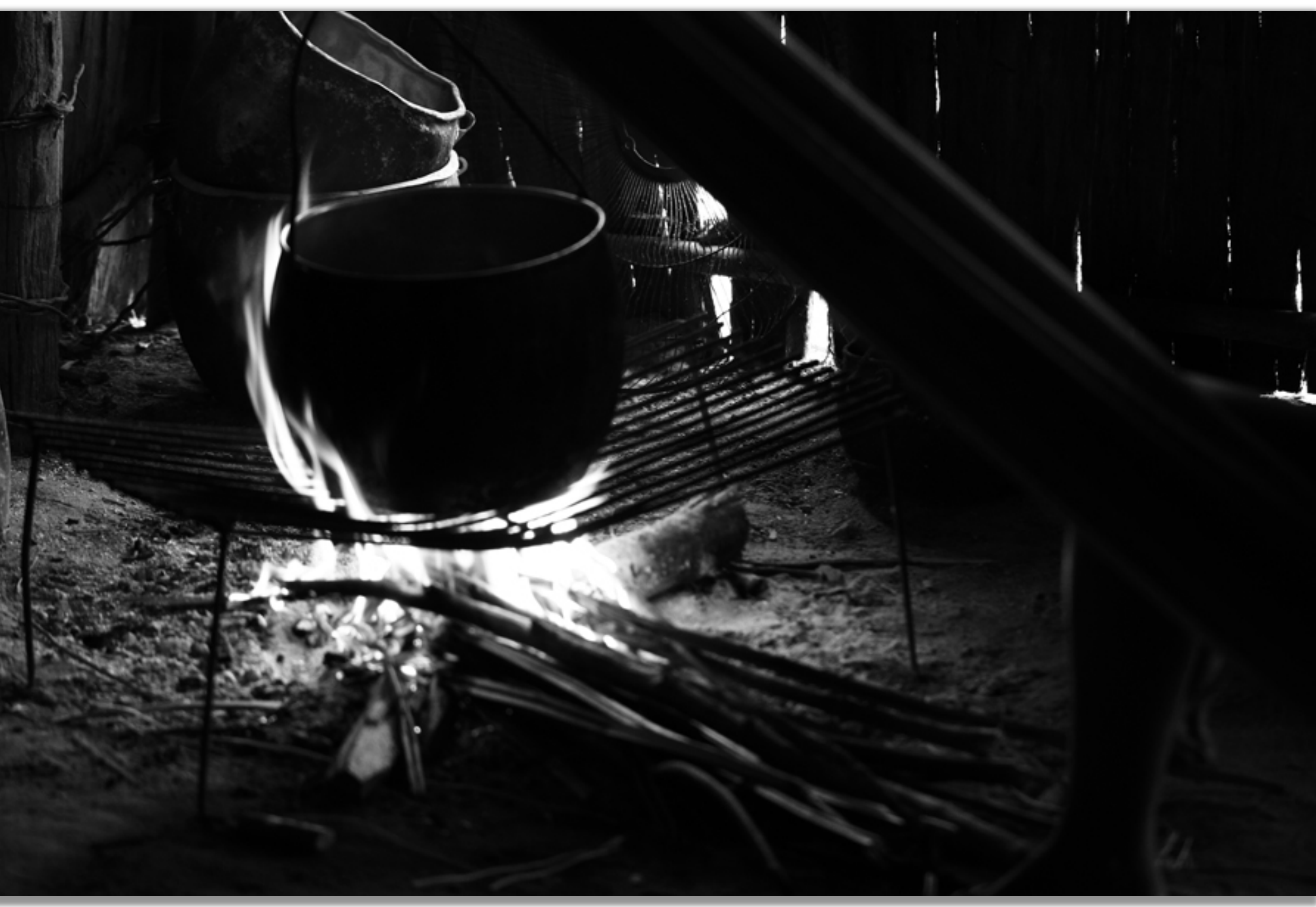


MEN'S WORK 


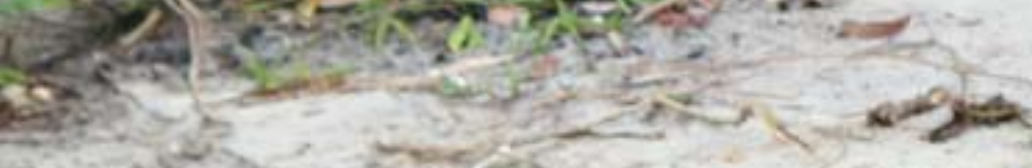

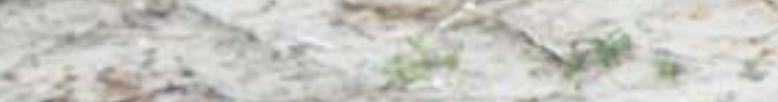

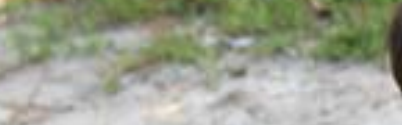




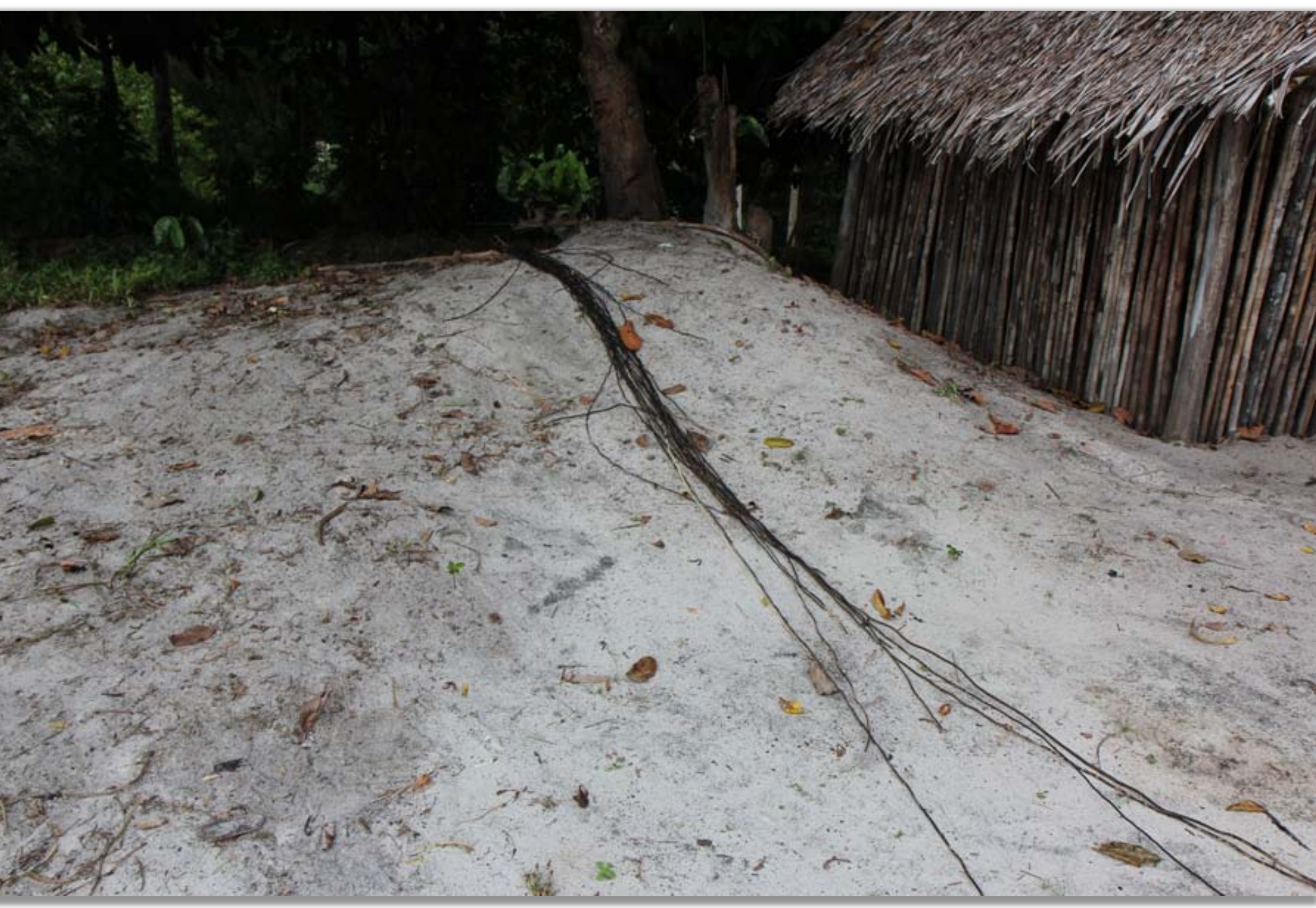

Vine to bind straw for roofs and for making tools 


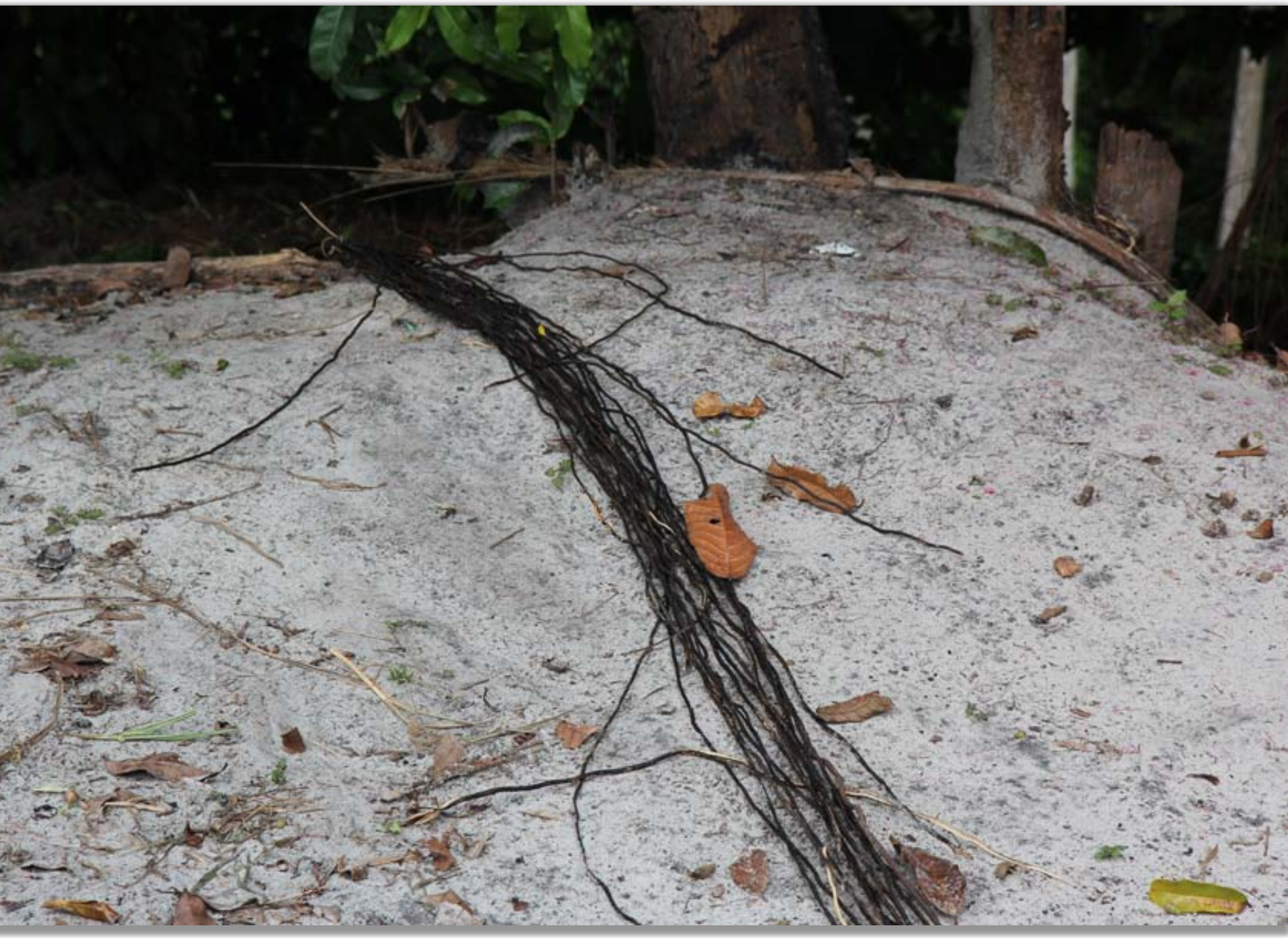




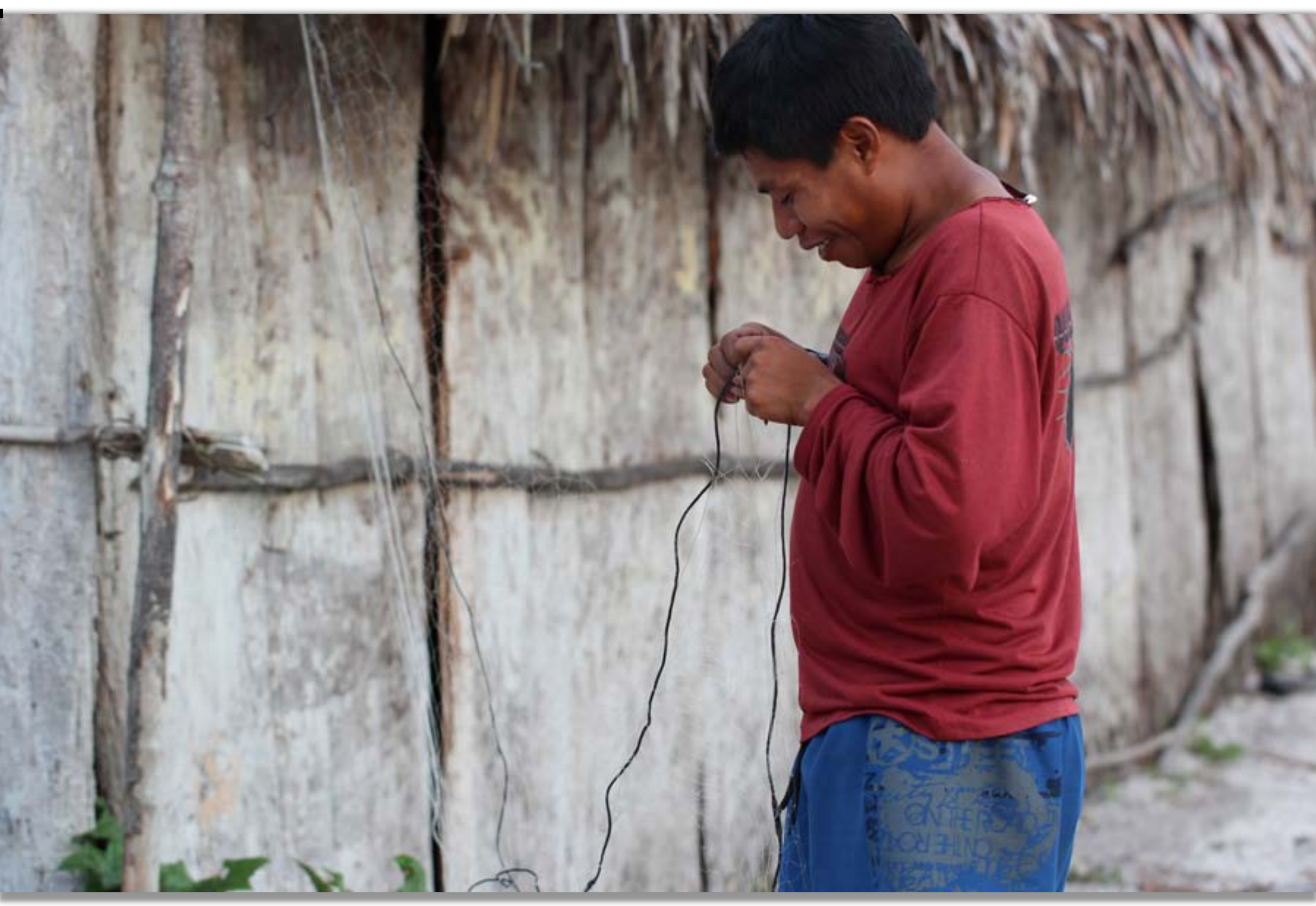




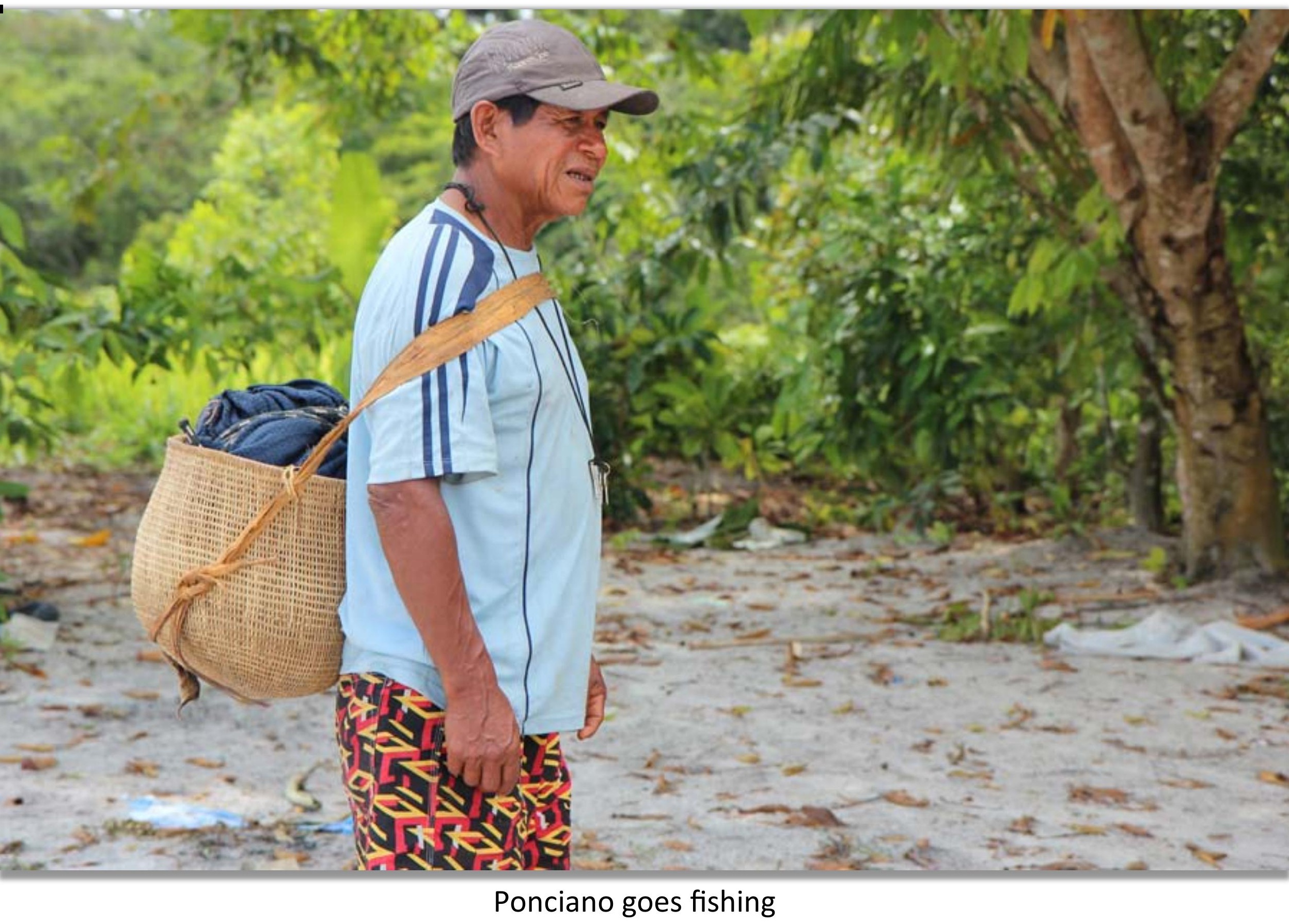




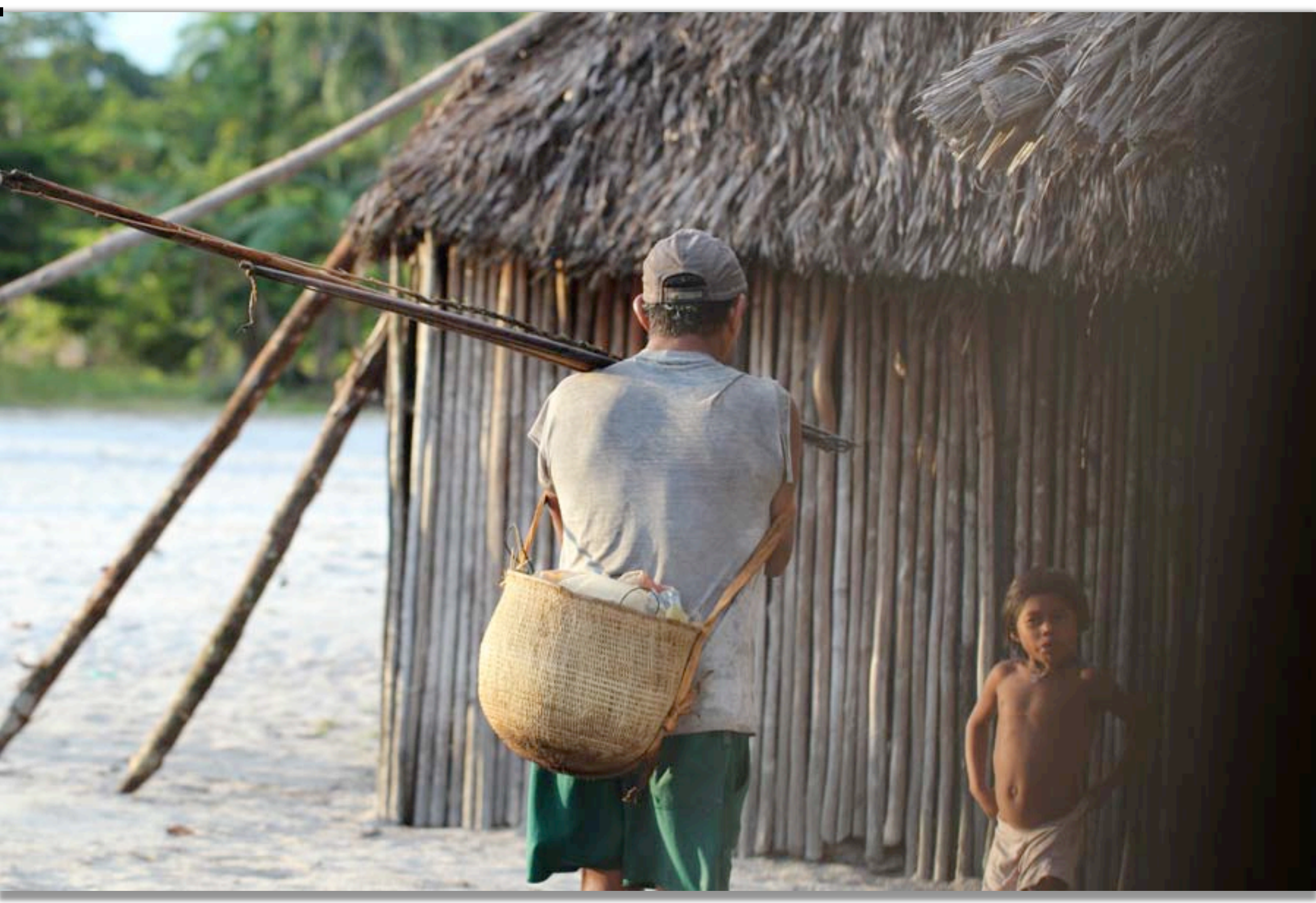




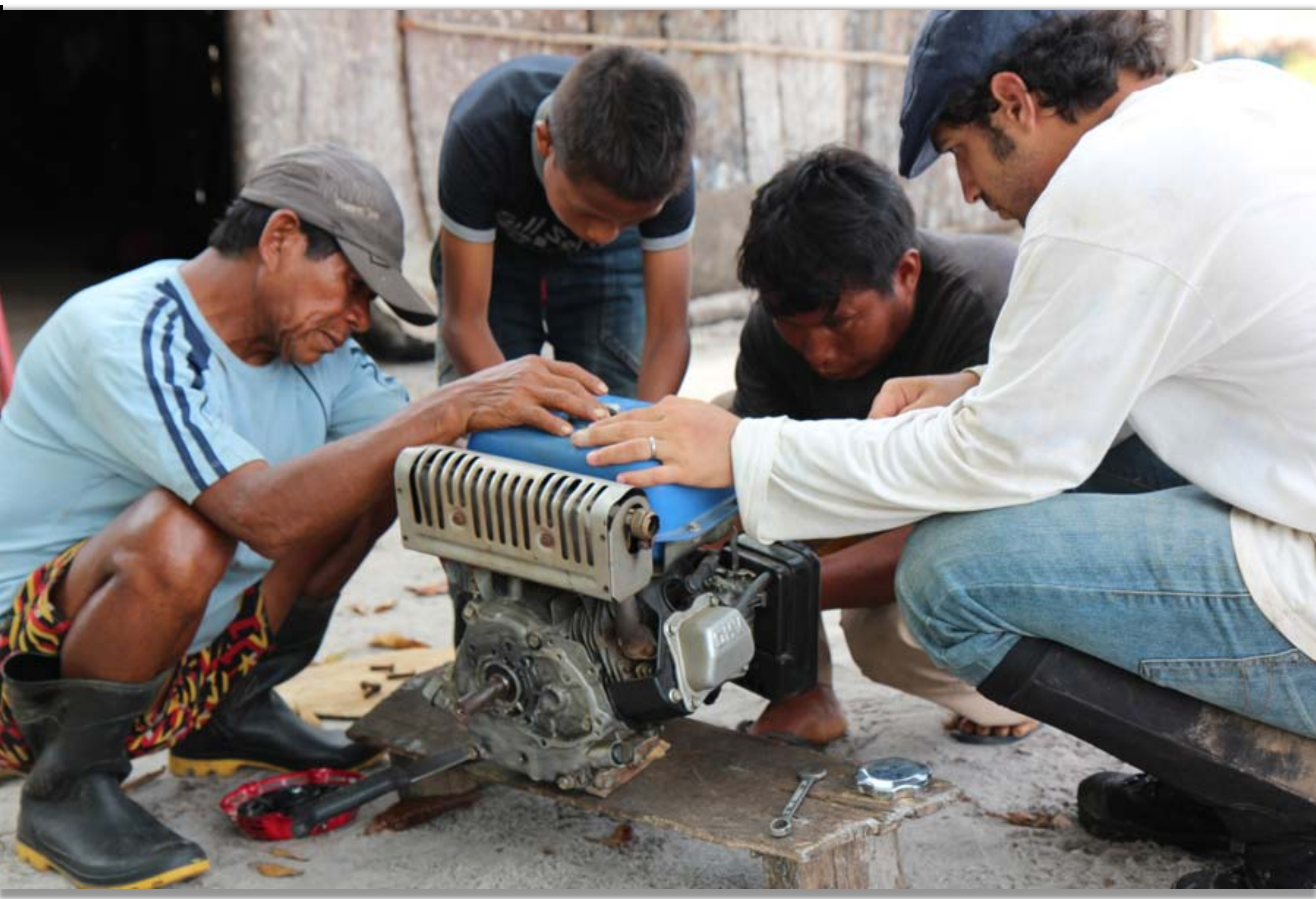

The canoe motor needs to be repaired 


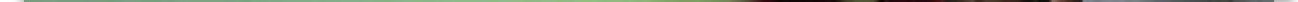




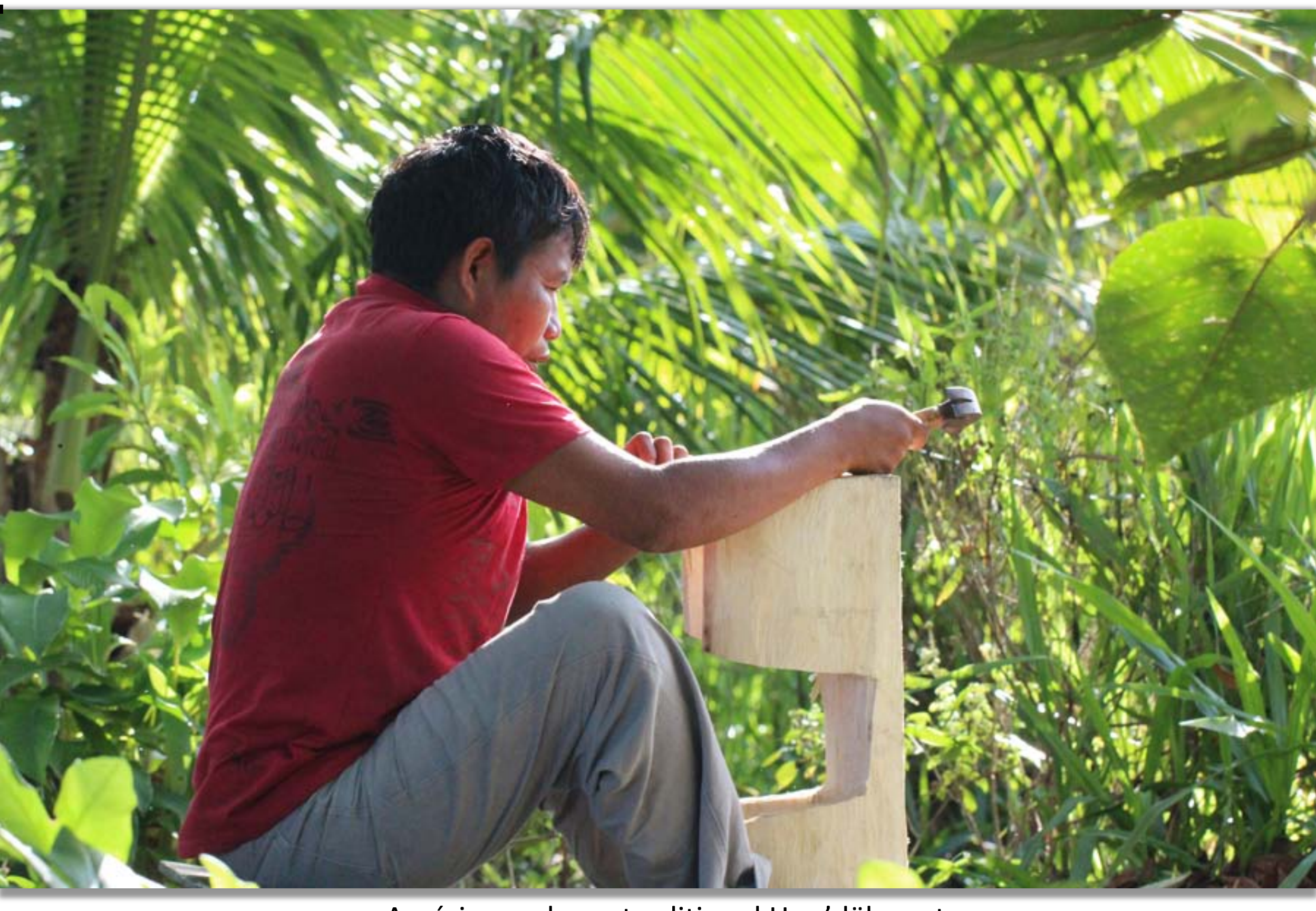

Américo makes a traditional Hup'däh seat 


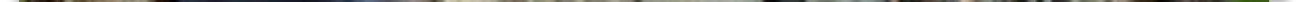




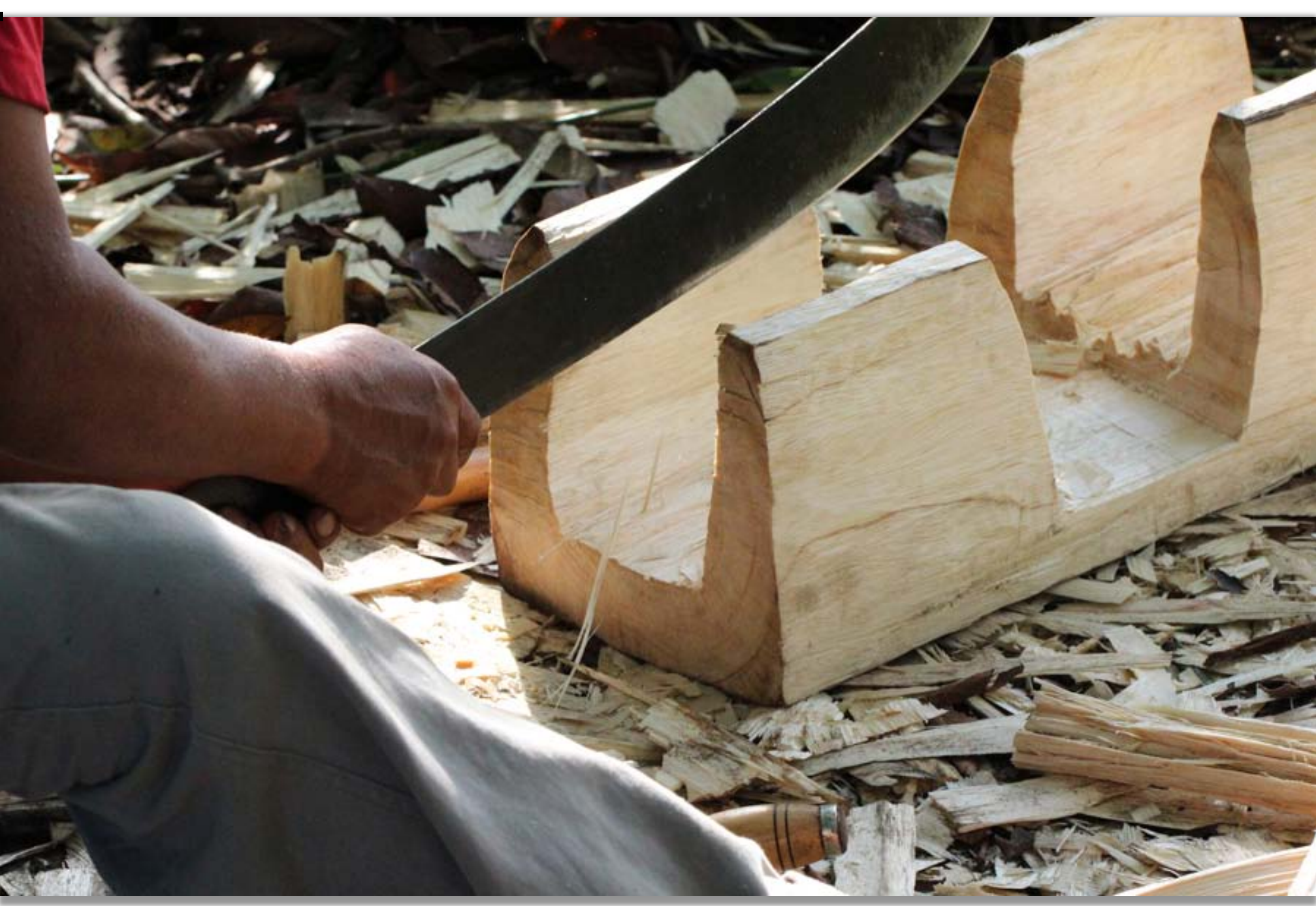




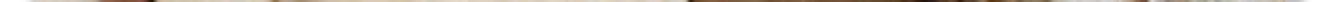




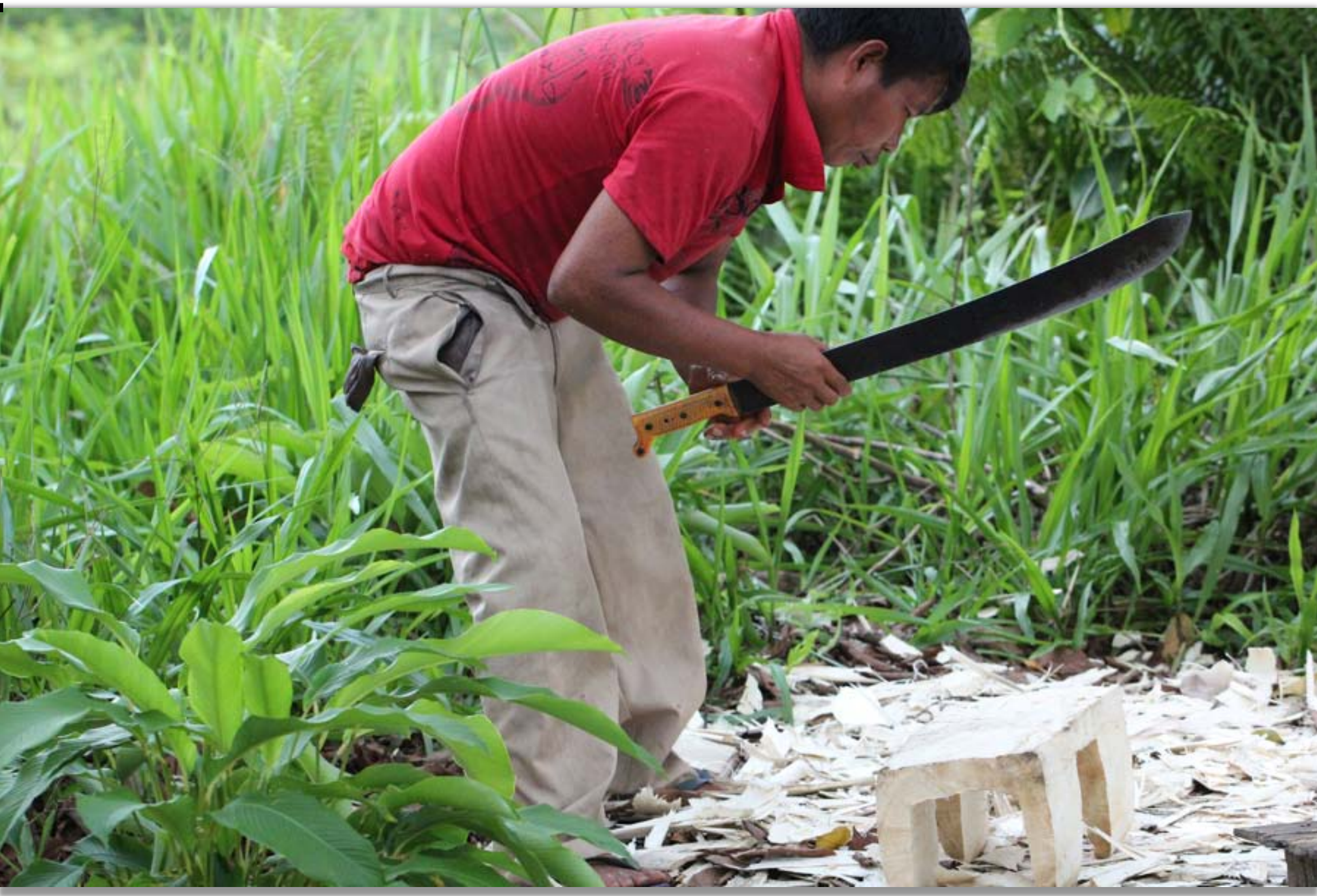

